8

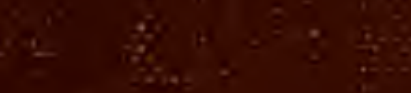

$\pm 2=3$

$0 \%$ -

$\frac{1}{3}$

$=3$

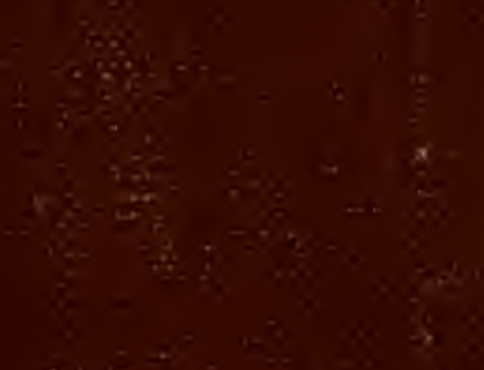

补

is: 30

柿

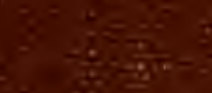

45

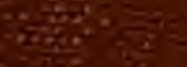

$\rightarrow$

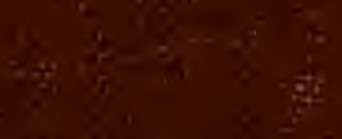

$\therefore=$

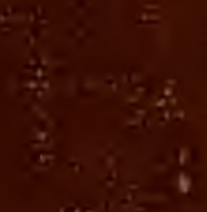




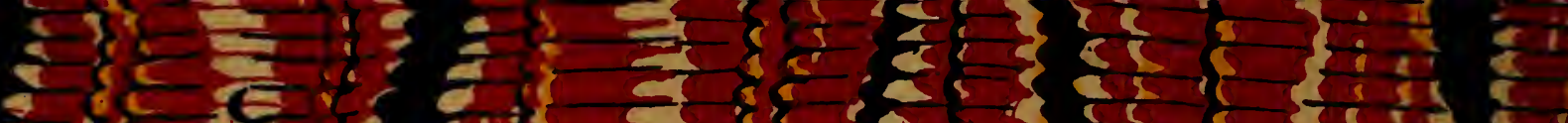

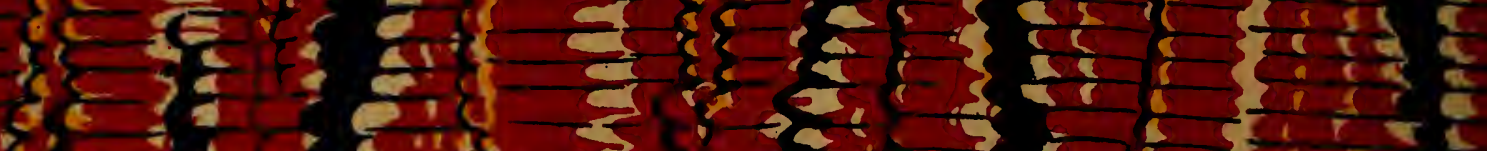

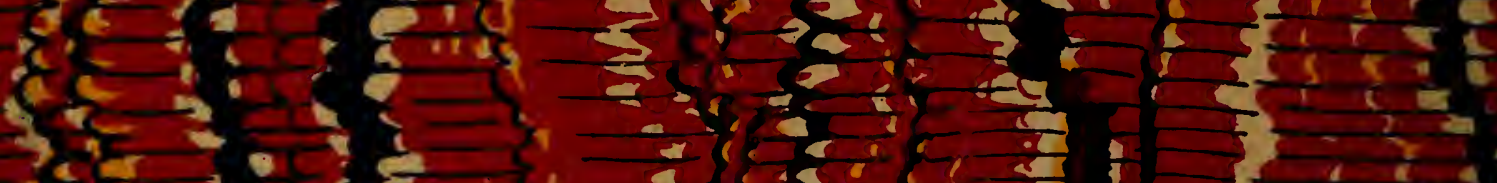

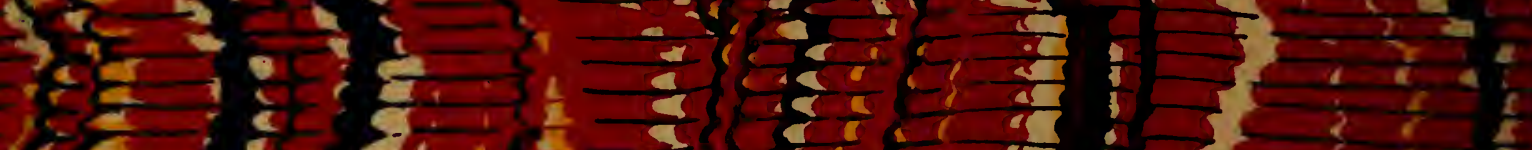

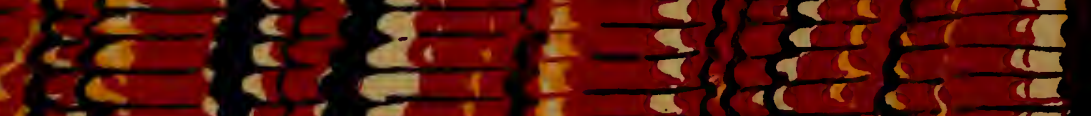

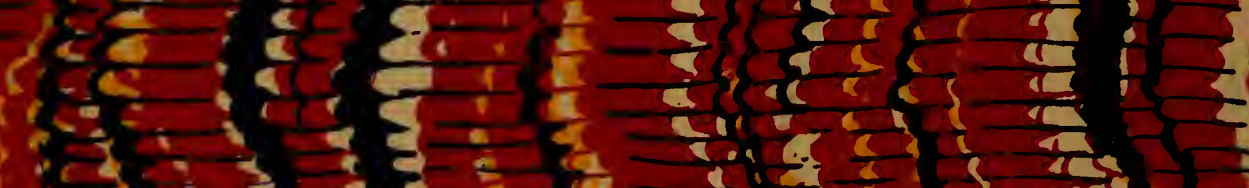

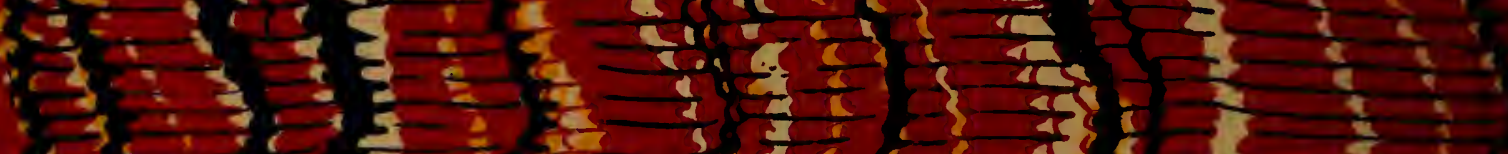

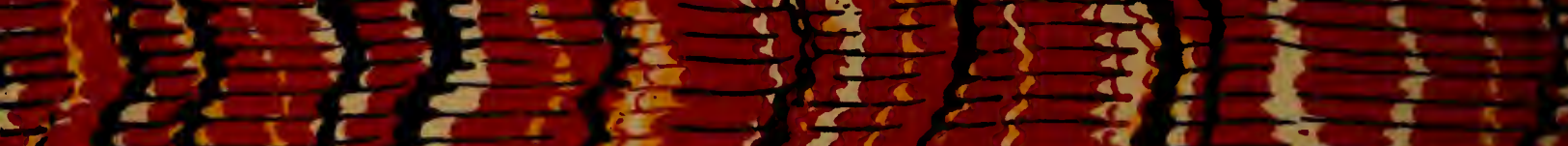

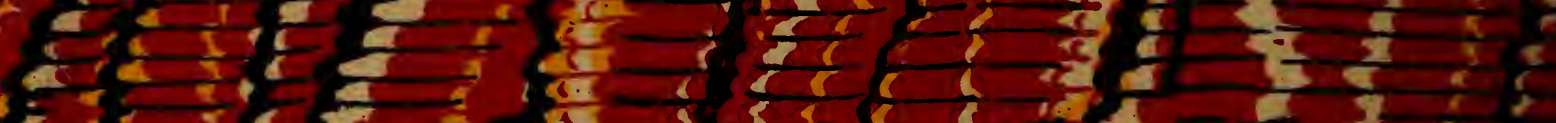

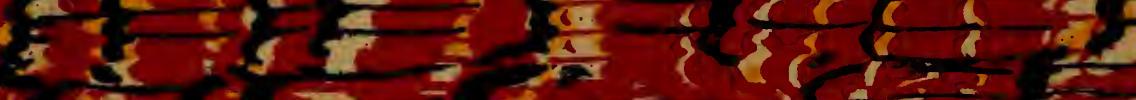

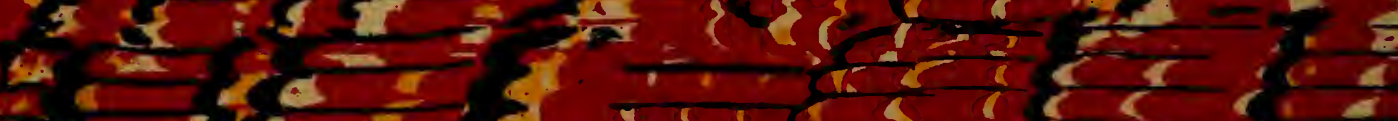
Q

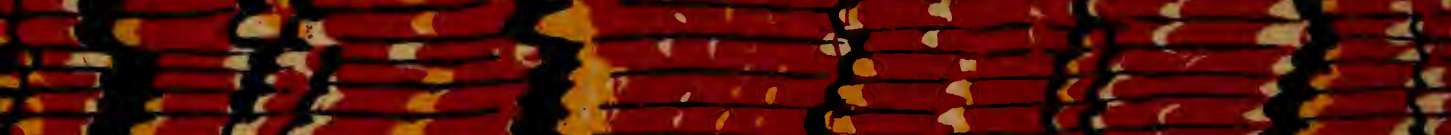

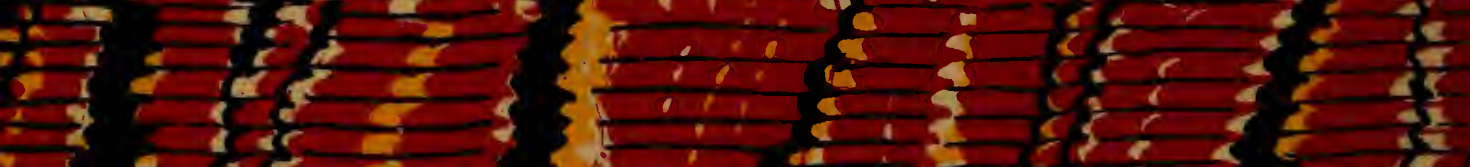

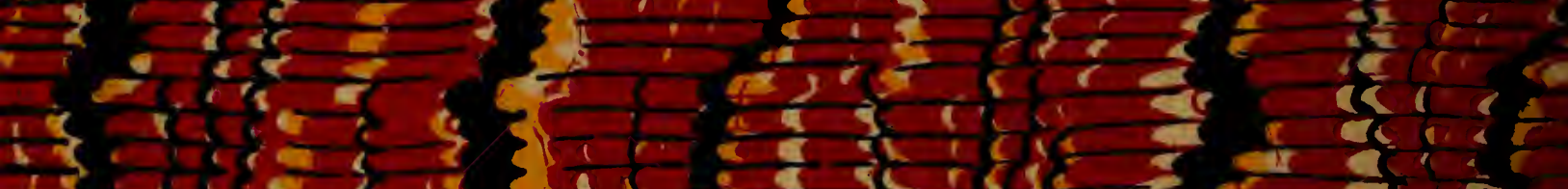

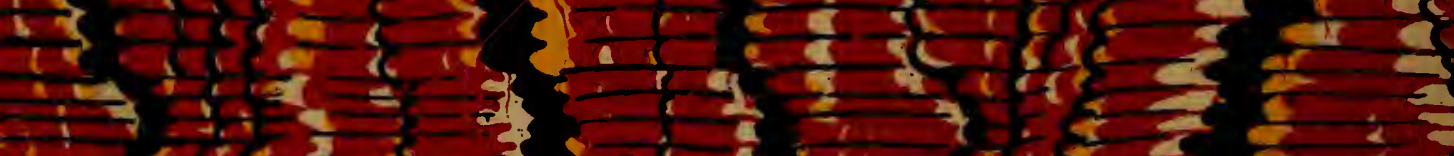

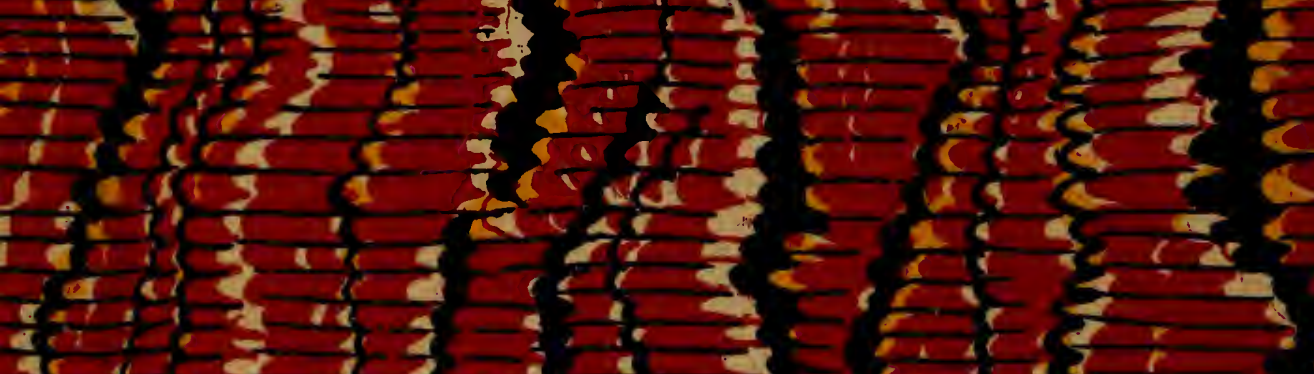
and

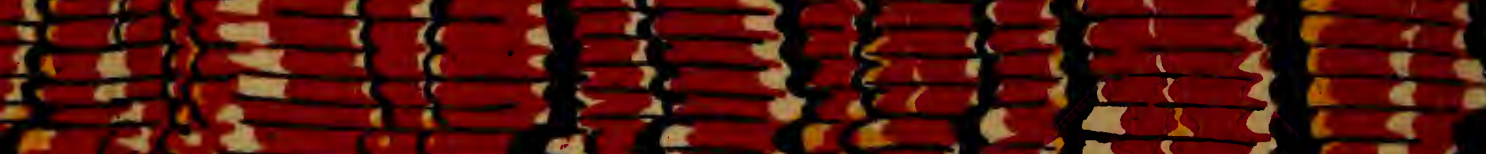

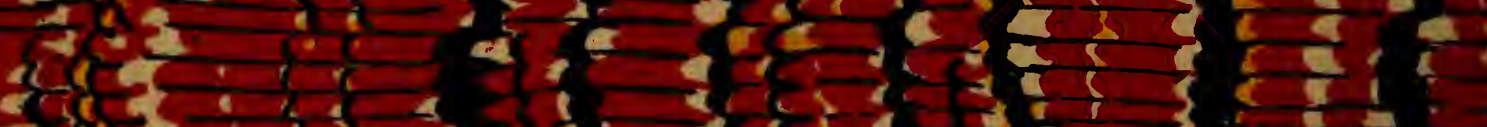

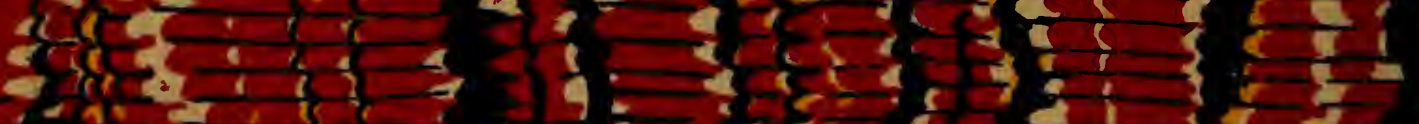
E

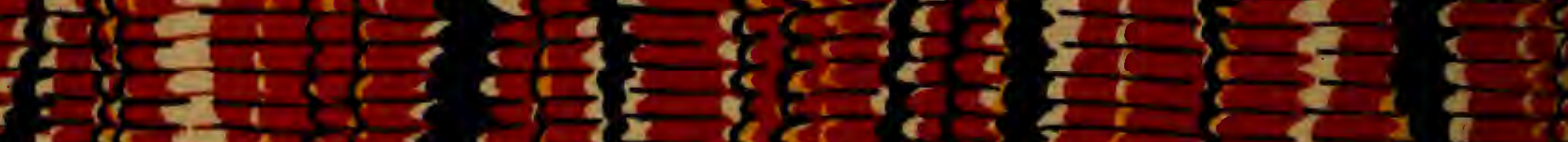

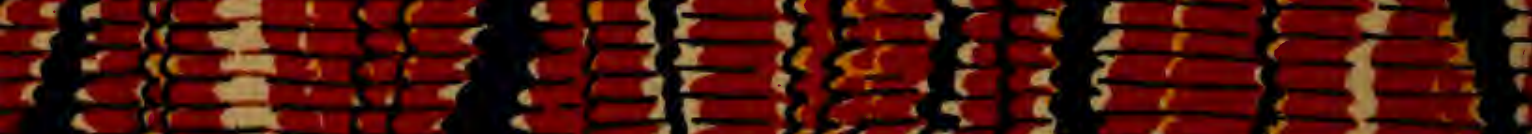

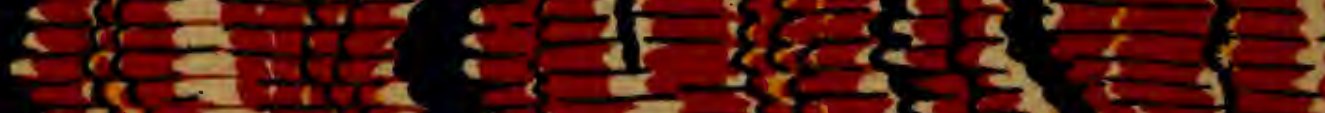

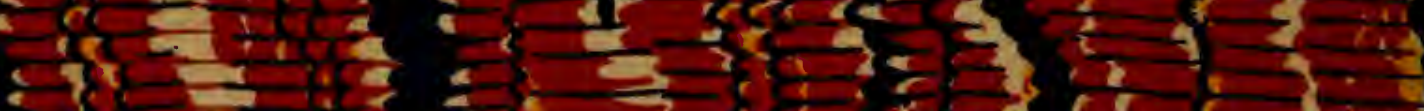

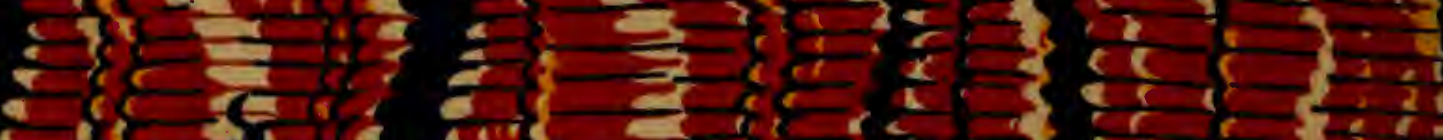

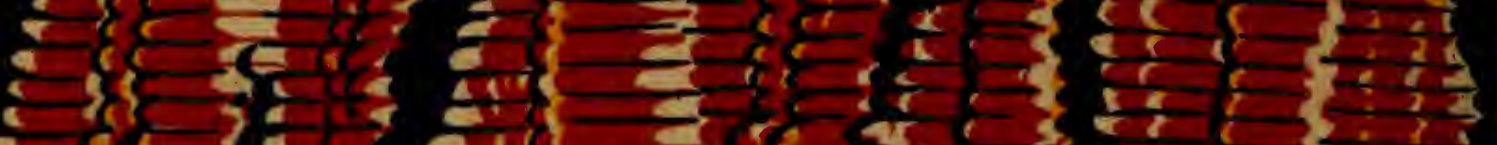

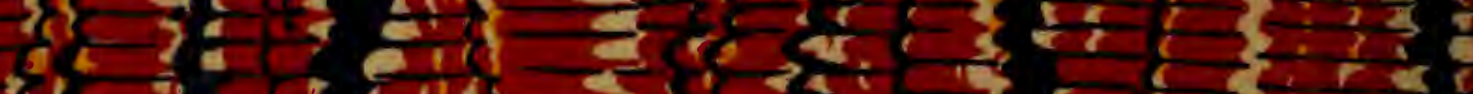

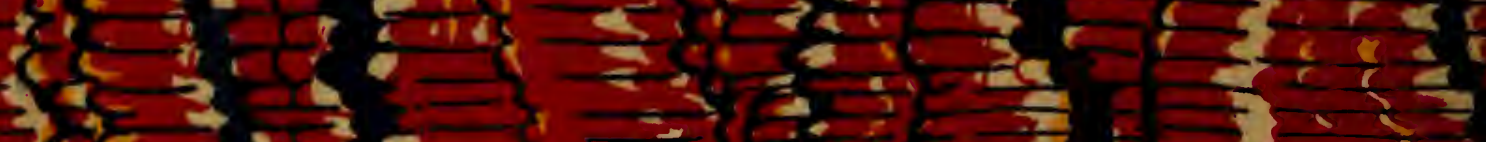

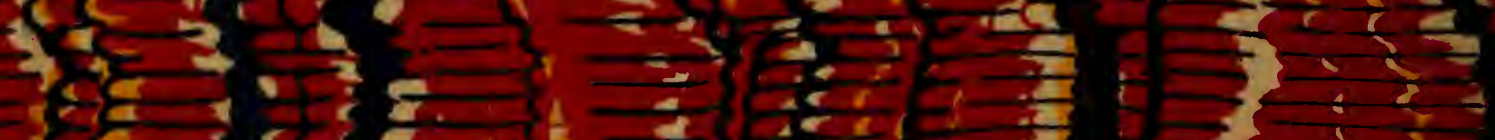

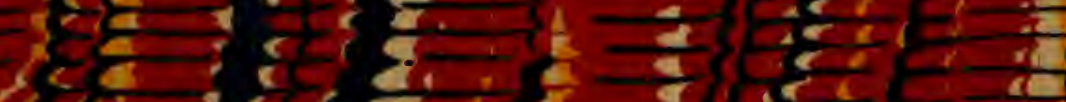

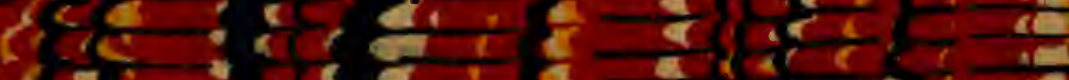

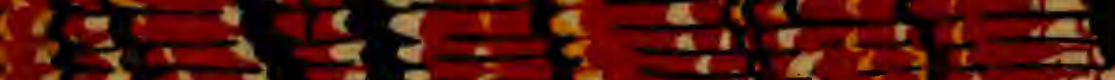
랄 
4.

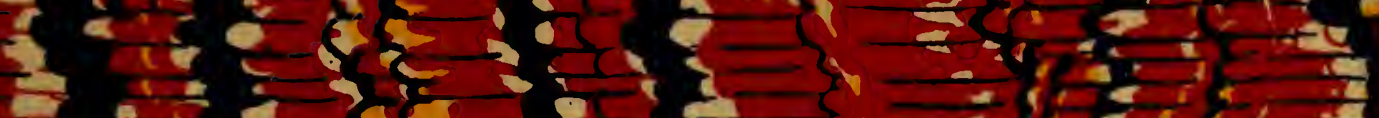
and

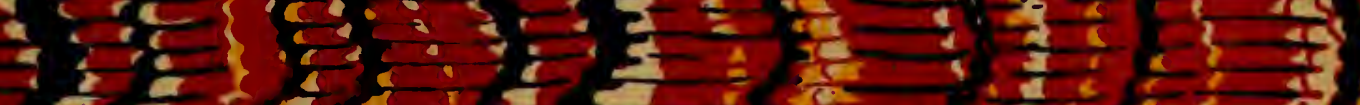

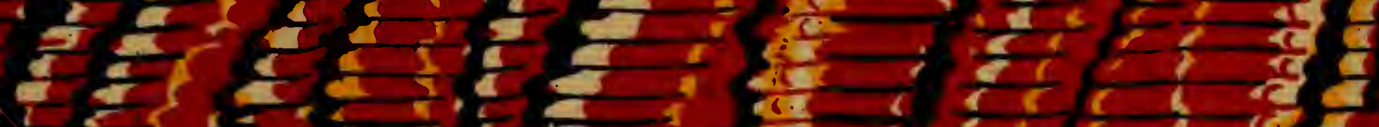

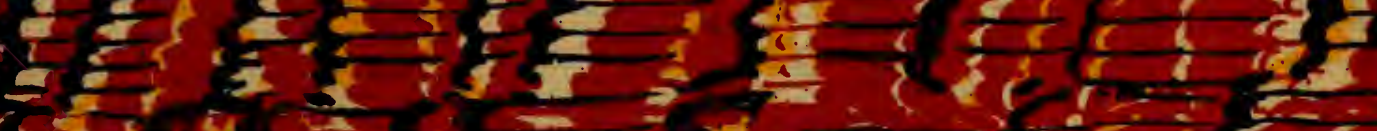

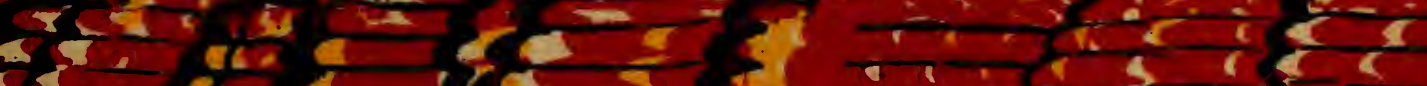

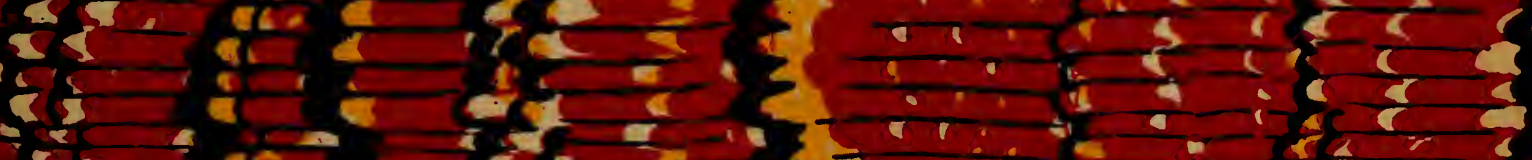

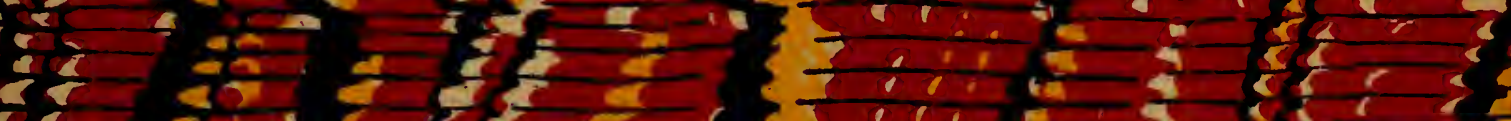

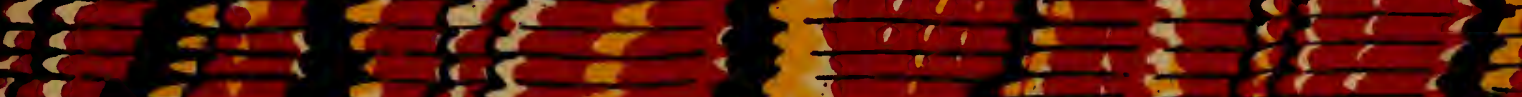

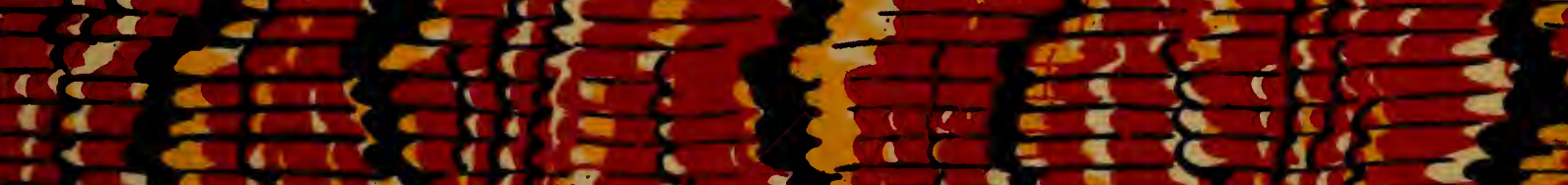

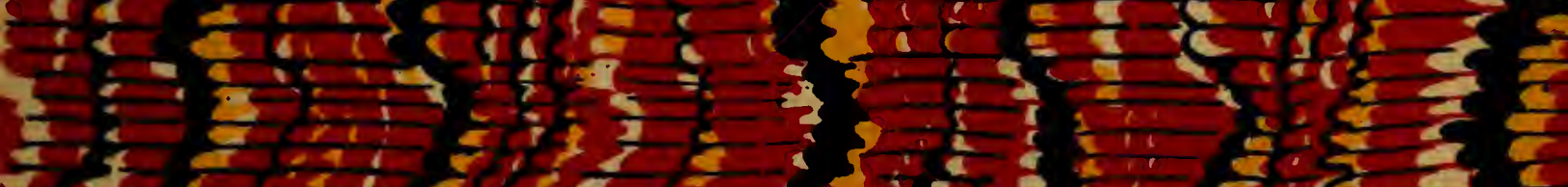

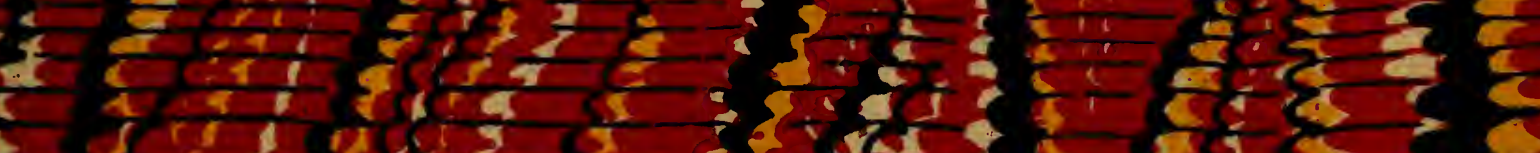

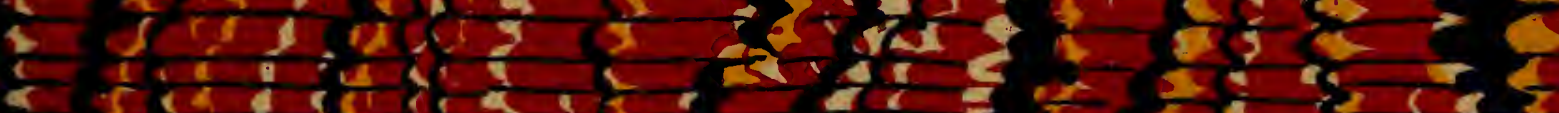

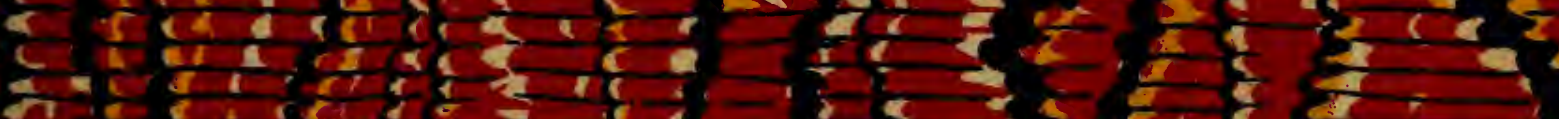

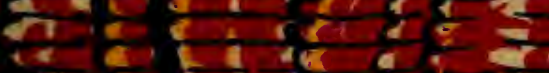

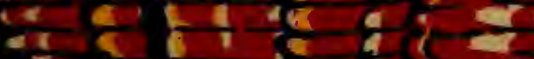

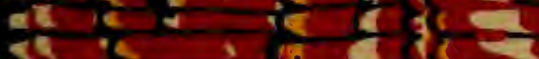

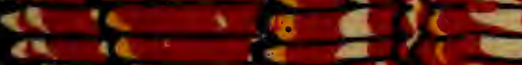

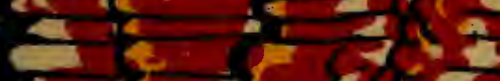

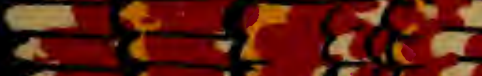

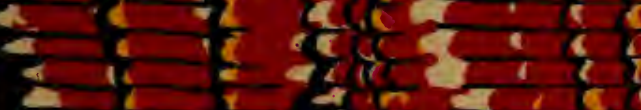

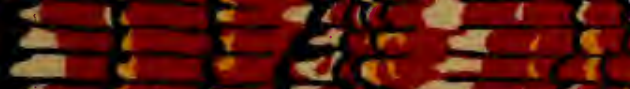

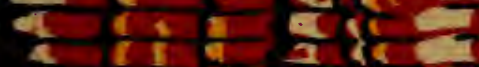
aric $-10=$ if if

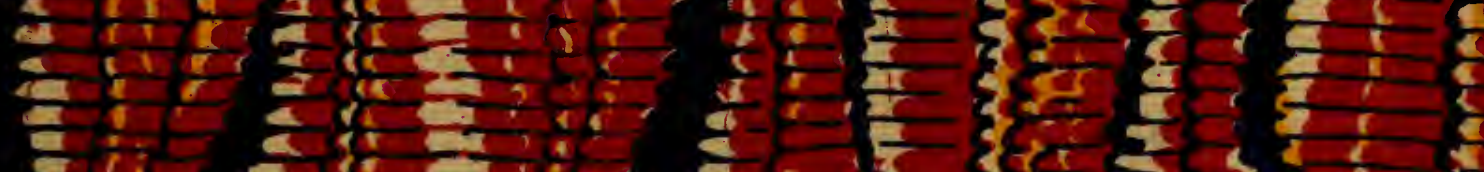

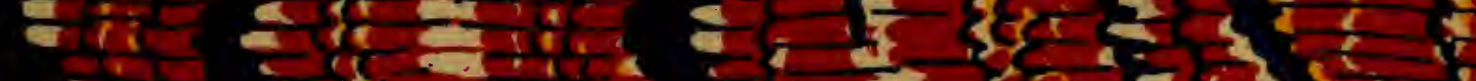

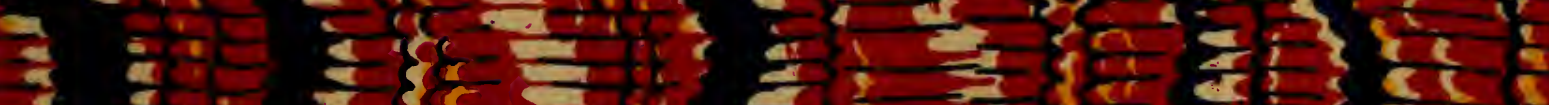

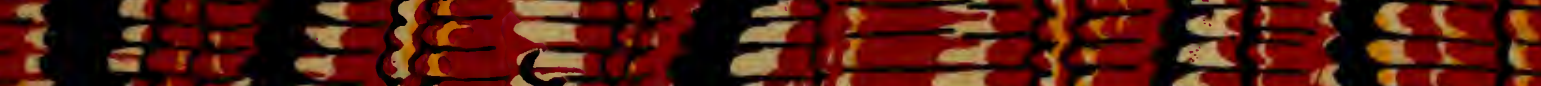

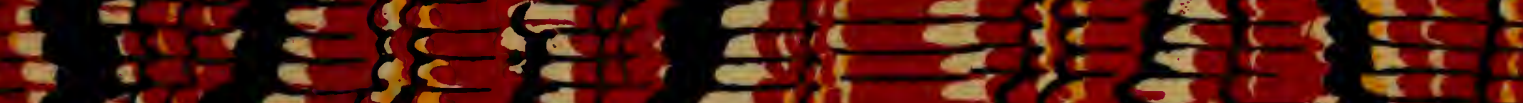

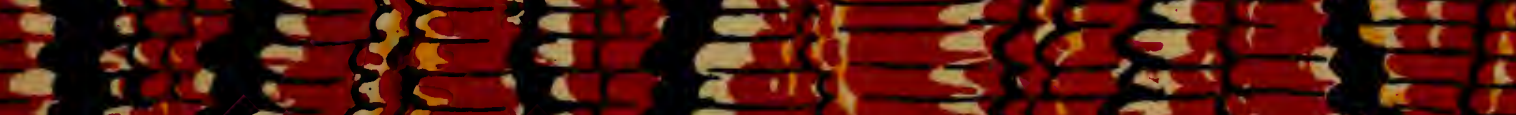

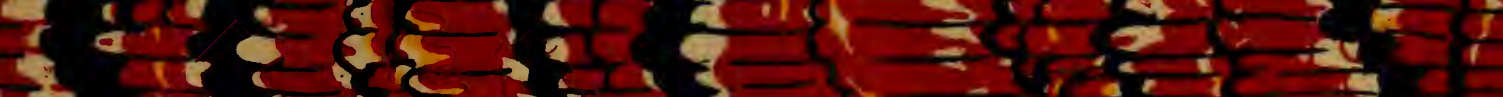

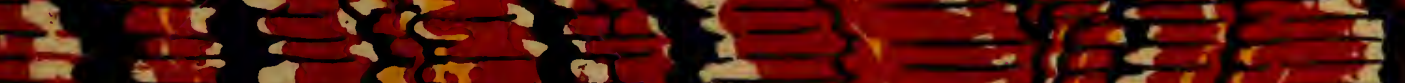

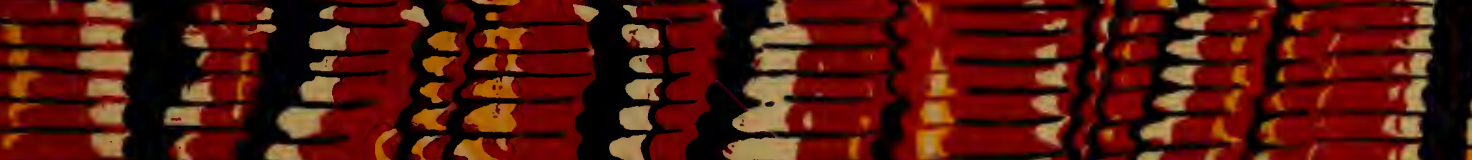
प:

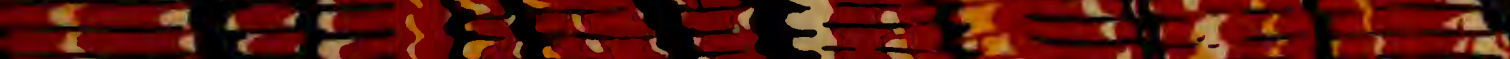




$$
\begin{aligned}
& d \\
& \sigma \\
& \sigma \\
& \frac{\gamma}{0} \\
& 0 \\
& 0 \\
& 0 \\
& 0 \\
& 0
\end{aligned}
$$

$$
\frac{\infty}{1}
$$$$
-
$$ 




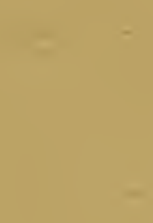



mof tuthoun

$82 \div 2$

OCCASIONAL PAPERS

OF THE

California Academy of Sciences

VII

\section{SYNOPSIS}

California Stalk-Eyed

Crustacea

BY

Samuel J. Holmes

SAN FRANCISCO

Issued. June 15, 1900

$2767 / 6$

Caimfornia Academy of Sciences

Ig0o 



\section{Occasional Papers}

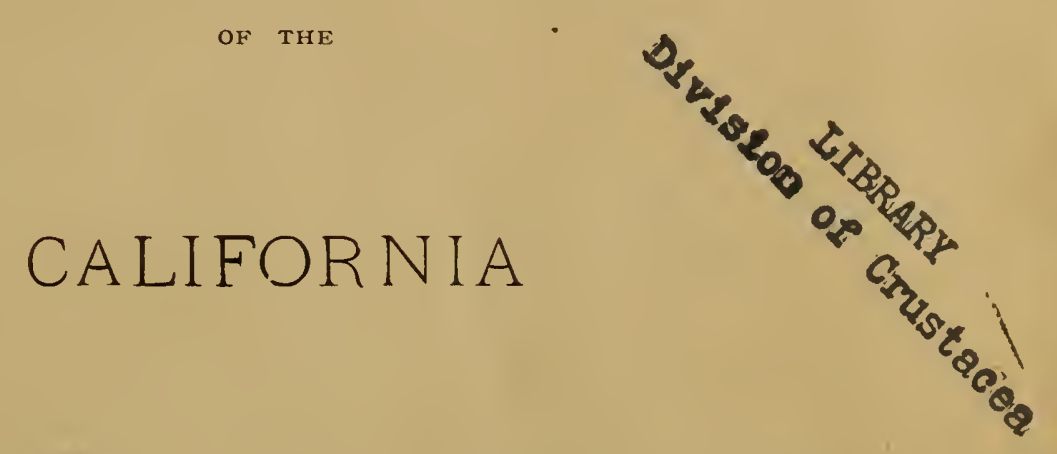

ACADEMY OF SCIENCES

VI I

SAN FRANCISCO

I900 


\section{PUBLICATION COMMITTEE.}

\section{Charles H. Gilbert, Chairman.}
William E. Ritter,
G. P. RIXFORD.

EDITORS OF ZOOLOGICAL PUBLICATIONS. 
QL

444

$1433+642$

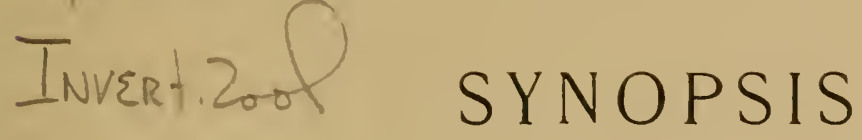

OF

\section{California Stalk-Eyed Crustacea}

SMITHSONIAN'Ssmed June 15, 1900

SEP 0 y 1986

LIBRARIESS
SAN FRANCISCO

California Acadeny of Sciences

I9O0 
Printed From the

Hendrie Publication Fund. 


\section{PREFACE.}

The aim of the present paper is to give descriptions of the species of Stalk-eyed Crustacea which are found on the west coast of the United States. For the benefit of students of natural history, who have at present few readily accessible means of identifying the invertebrate animals of this coast, definitions of genera and higher divisions have been inserted, and a description given, in the Introduction, of those parts of the structure of the Decapod Crustacea which are most used for the purpose of classification. The endeavor has been made to enable those who have not previously studied the Crustacea to determine the specific names of the forms here described. The rules of nomenclature of the American Ornithologists' Union have been followed, except in case of the canon, not insisted on by the framers of the code, that specific names derived from the names of persons be written with a small letter. Localities from which I have examined specimens have usually been indicated by the note of exclamation, !.

The larger portion of this paper was completed at the University of California in 1895 , but it has received some additions and considerable revision since that date. I wish to express my indebtedness to Prof. Wm. E. Ritter of the University of California for many favors in connection with my work, and to Dr. H. P. Johnson and Dr. F. W. Bancroft for several valuable specimens and for assistance in many other ways. Through the kindness of Dr. Gustav Eisen I have had 
the privilege of studying the collections of Crustacea in the California Academy of Sciences. The examination of Mr. Lockington's type specimens, many of which are in the possession of the Academy, has made it possible to straighten out some questions which otherwise would scarcely have been capable of solution. To Mr. Rivers and Mr. Harford, formerly of the University of California, I am indebted for the privilege of studying the collections in the University museum. From Miss Mary J. Rathbun and Dr. James E. Benedict of the U. S. National Museum much valuable aid has been received which is gratefully acknowledged.

S. J. HOLMES.

UNIVERSITY OF MICHIGAN,

Ann Arbor, Mich.

January 20, 1900. 


\title{
SYNOPSIS OF CALIFORNIA STALK-EYED CRUSTACEA.
}

\author{
BY SAMUEL J. HOLMES.
}

\section{IN T R O D U C T I ON.}

THE Crustacea are commonly divided into two principal groups, the Malacostraca and the Entomostraca, although the primary divisions of the latter group may well be, as they often are, considered cöordinate with the former. There is such great diversity of form among the Entomostraca that the group is scarcely definable except by negative characters. The number of segments composing the body is very variable and the openings of the genital ducts do not occur in the same segment in all the members of the group. There is no masticatory stomach and corresponding appendages are modified in most diverse ways in different orders. The Malacostraca, on the other hand, while they include a great variety of forms, constitute a wel] defined subclass. Except in cases in which it is quite evident that certain segments are fused or lost, the body is composed of twenty (or in Nebalia of twenty-one) segments. The typical number of appendages is nineteen. There is a pair of compound lateral eyes, and the stomach, except in a few parasitic species, is masticatory. The genital ducts of the male open on the last thoracic segment; those of the female on the antepenultimate one. The head is typically composed of five segments 
and the thorax of eight, some or all of which may fuse with the head forming a more or less complete cephalothorax. The abdomen is sharply marked off from the thorax and consists of seven (in Nebalia of eight) segments, all of which, except the Jast, the telson, may bear articulated appendages.

The Malacostraca may be divided as follows:-

Body composed of 21 segments and furnished with a bivalve shell.

Leptostraca.

Body composed of 20 segments and not furnished with a well defined carapace. Eyes sessile....................... Arthrostraca. Body composed of 20 segments and furnished with a well developed carapace which is never bivalved............... Thoracostraca.

Synopsis of THE Thoracostraca.

Eyes sessile. Cumacea. Eyes stalked.

Carapace rather small, not covering all of the thoracic segments. The thoracic feet dissimilar, the anterior ones devoid of exopods.

Stomatopoda.

Carapace covering some or all of the thorax but not joined to the posterior segments. Thoracic feet usually similar, biramous.

Schizopoda.

Carapace covering and joined to all of the thoracic segments. The three anterior thoracic feet generally biramous and modified into

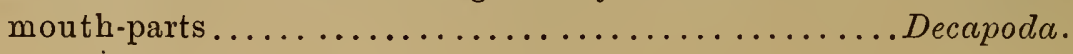

As it is with the Decapoda that we are here mainly concerned, those parts of the structure of these animals which are most used for the purpose of classification will be briefly described. The exoskeleton of a Decapod. crustacean may be considered as a series of rings, each of which, with the exception of the last, is typically furnished with a pair of articulated appendages. These. rings and their appendages are modified in various ways in different regions of the body in relation to the different functions they are called upon to perform. 
The segments in some parts become fused together so completely that they manifest no external signs of metamerism except the appendages they carry. The five segments forming the head are usually thus indistinguishably fused. The eight following segments, with the rare exception of the last one, are fused together and with the head, forming the cephalothorax; but the sutures between the rings are, in this case, generally visible on the ventral, or sternal surface and at the sides. The abdomen is, in all cases, clearly marked off from the thorax, and is typically composed of seven segments. The number of joints may, however, be secondarily reduced by the concrescence or disappearance of some of the rings.

The Carapace. - The carapace of the Decapod crustacea is considered to be a fold of the dorsal integument of one or more of the cephalic segments which extends backward over, and fuses with the dorsal portion of all of the thoracic segments and is produced downwards at the sides over the gills. The form of the carapace commonly found in the Macroura is shown in the following cut:-

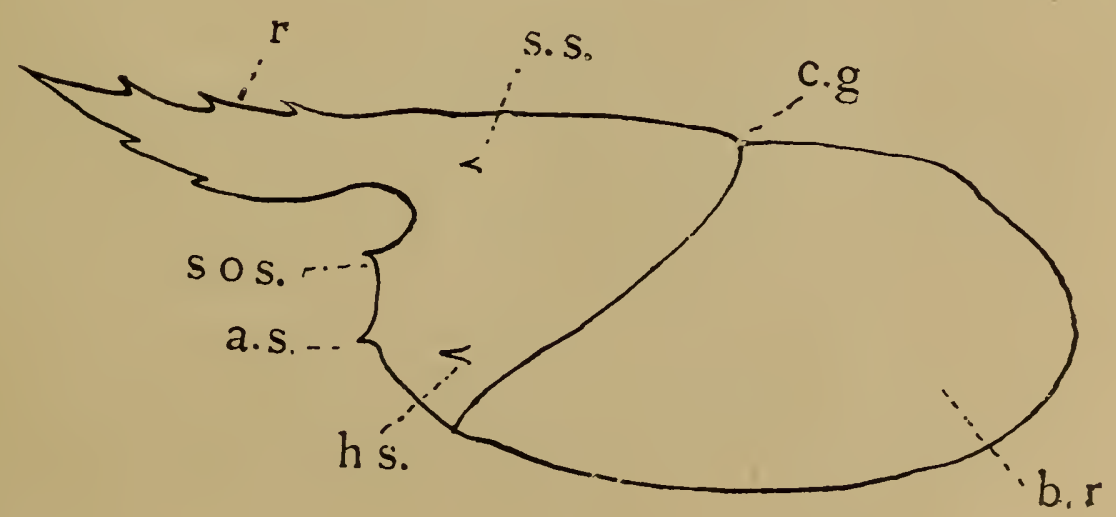

Fig 1.-Macrouran Carapace. a. $s$, antennal spine; $b . r$, branchial region; $c . g$, cervical groove; $h . s$, hepatic spine; $r$, rostrum; $s . o . s$, suborbital spine; $s . s$, supraorbital spine. 
The typical Macrouran carapace is elongated, and the anterior end is produced into a rostrum. The anterior region of the carapace is often furnished with teeth or spines which occur in the following positions: the supraorbital spine, or spines, above the orbit; the suborbital spine on the anterior margin of the carapace below the orbit; the antennal spine below the last and behind the base of the antenna; the hepatic spine on the hepatic region. Any or all of these spines may be present or absent. There is generally visible a groove, known as the cervical groove, which extends downwards and forwards from the dorsal surface of the carapace, marking the line of union of the head and thorax. The dorsal surface in front of this groove is termed the gastric region, the hepatic regions lying at the sides; immediately behind the gastric region is the cardiac, while the intestinal region lies behind the latter at the posterior end of the carapace; the sides of the carapace behind the cervical groove are known as the branchial regions, since they form a covering for the branchiæ, or gills.

In the Brachyura the carapace is wide and generally flattened, and the rostrum is small or absent. The regions are generally separated from each other by sulci, or grooves, and there are usually more regions marked out than in the Macroura. The cervical groove is usually visible and divides the gastric and hepatic from the cardiac and branchial regions. On the sides of the carapace below the lateral margins there are (1), the pterygostomian region on either side of the mouth area and (2), the sub-branchial regions below the branchial areas. The names of the regions which appear on the dorsal surface may be obtained from fig. 2 . The distinctness of these areas is subject to great variation in 
different forms. In some cases the outlines of all the regions are very clear, while in others they may be entirely obliterated. Other areas are sometimes given names but they are of little importance.

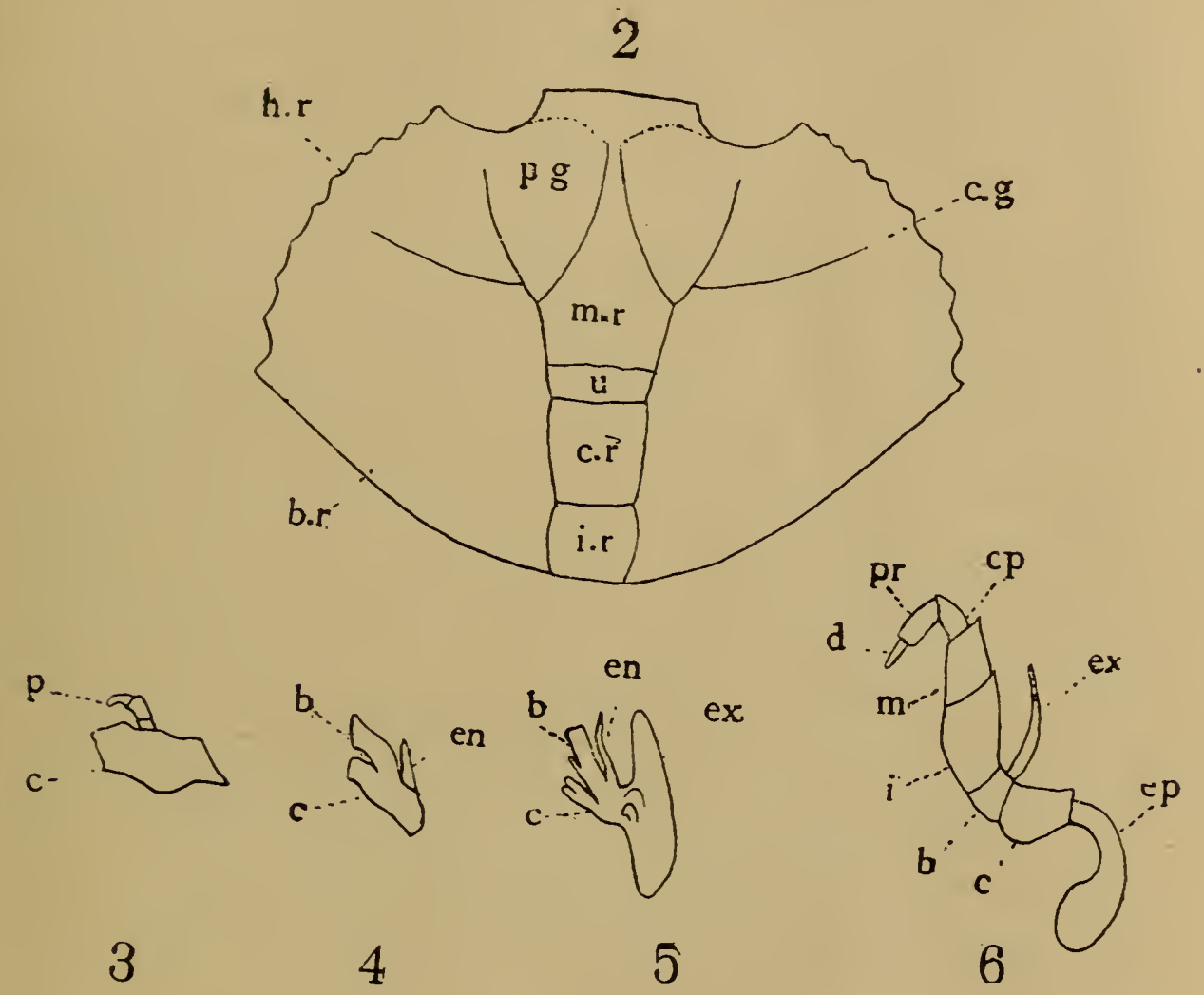

Fig. 2.-Carapace of a crab. 3.- Iandible of a crayfish. 4.-First maxilla. 5.Second maxilla. 6.--Third maxilliped. $b$, basipodite; $b, r$, branchial region; $c$, coxopodite; $c . g$, cervical groove; $c p$, carpus; $c . r$, cardiac region; $d$, dactyl; en, endopodite; $e p$, epipodite; ex, exopodite; $h . r$, hepatic region; $i$, ischium; $i . r$, intestinal region; $m$, merus; $m . r$, mesogastric region: $p$, palp; $p . g$, protogastric areas; $p r$, propodus; $r$, rostrum; $u$, urogastric area.

\section{THE APPENDAGES.}

With the exception of the eyes and the first pair of antennæ all of the appendages of a Decapod crustacean may be considered modifications of a common type 
consisting of a basal portion, the protopodite, and two terminal rami. The first basal joint, the coxopodite, or coxa, usually bears a branchial appendage, or epipodite; the second joint, the basipodite, carries the two rami; the inner ramus is called the endopodite, the outer the exopodite. In the Decapods the endopodite of the thoracic appendages is typically composed of five joints which, counting from the basipodite, are designated as the ischium, merus, carpus, propodus, and dactyl. In the appendages which precede and in those which follow the thorax the endopodite is undivided, or composed of less than five true joints. The appendages will be described in their order from before backwards.

The Eyes and Orbits.-The eyes in all of the Decapods are compound and situated at the end of movable stalks. These stalks, however, are probably not homologous with the other appendages. The orbits in the Macroura are generally represented by excavations in the anterior margin of the carapace, but in the Brachyura they form well defined cavities into which the eye-stalks can be withdrawn. The number and position of the orbital fissures are important characters for the purpose of classification.

The First and Second Antennce.-The first antennæ, or antennules, unlike the succeeding appendages, are not typically biramous. It is true that they may bear two terminal branches, or in some of the lower Macroura even three, but it is quite clear that this condition is a secondary one. The basal portion, or peduncle, normally consists of three joints, in the first of which is located the auditory organ. In the Brachyura the antennules are small, and located in cavities called fossettes. 
The second antennæ are usually larger than the first pair and situated behind or external to them. The exopod is represented by a scale, or acicle, attached to the second basal joint, but this structure is often absent, especially in the higher forms. The peduncle usually contains four or five joints and bears an annulated, terminal portion, the flagellum. The first joint contains the opening of the renal organ and is often immovably joined to the carapace.

The Mundibles.-The appendages which function as mandibles are highly modified. The first joint (coxopodite) is enlarged and modified for the purpose of mastication; this part is called the trunk and its inner edge is generally dentate and often divided into a lower portion, or molar process, and an upper cutting edge. The trunk bears a jointed appendage, or palp, which, in this group, never consists of more than three joints.

The First and Second Maxilla._The first maxillæ are always small and foliaceous. The two basal joints are flattened and produced inward; there is a small endopodite; the exopodite is usually absent. In the second maxillæ the two basal joints are modified much like those of the first pair. There is a small endopodite outside of which is joined a large, flattened appendage (exopodite, scaphognathite) which serves to produce a current of water from the branchial chamber.

The First Maxillipeds.-These are the first thoracic appendages. The two basal joints are flattened and produced, forming the so-called lacinire, or masticatory ridges. The endopod is small and generally joined to a greater or less extent to the exopod; the latter is well developed and ends in an annulated, terminal portion, or palp. 
The Second Maxillipeds. - The second maxillipeds are more like the third pair than the first; the endopod is well developed and generally contains the typical number (five) of joints. The exopod is also well developed and furnished with a terminal palp. The epipod often bears one or more gills.

The Third Maxillipeds.-The endopod of the third maxillipeds is usually composed of five joints. In the Brachyura the ischium and merus are flattened and generally fitted neatly to the buccal area; the last three joints are small and are termed the palp; in the Macroura the joints of the third maxillipeds are usually rounded. The exopod may be well developed, but is sometimes wanting.

The Thoracic Legs, or Pereopods. - The thoracic legs, with rare exceptions, consist of seven joints, two or more of which are generally fused together. The exopod is wanting, except in some of the lower Macroura, where it is represented by a small, jointed appendage. One or more of the thoracic legs may be furnished with pincers or chelæ, in which case they are called chelipeds; the movable finger of the hand, or chela, is called the dactyl, the immovable one the pollex; the basal portion of the hand is known as the palm.

The Abdominal Appendages, or Pleopods. - The pleopods in the Macroura are generally furnished with flattened rami adapted for swimming; the posterior pair is usually much larger than the others and forms with the telson a strong tail fin. In the Brachyura these appendages are never employed in swimming; in the females they are used for holding the ova; in the males only one or two of the anterior pairs are retained as sexual appendages and these are sometimes wanting. 
The Gills.-The gills may be situated on the basal joints of the thoracic appendages (podobranchiæ), or on the articular membranes between the legs and the body (arthrobranchiæ), or on the sides of the thoracic segments (pleurobranchiæ). There are two types of gills-the trichobranchiæ, in which there are threadlike, branchial filaments arranged around a common stem, and the phyllobranchiæ, in which the stem bears on each side a row of thin, transverse lamellæ.

A few other structures deserve mention in this connection, viz.:-the epistoma, the area lying in front of the buccal, or mouth area and behind the antennules; the upper lip, a fleshy projection in front of the mandibles; the lower lip, a flap lying behind the mandibles; the thoracic sternum, or sternal plastron, the ventral portion of the thorax, and the terminal segment of the Macrouran abdomen, the telson.

\section{Tribe BRACHYURA.}

Carapace broad. Orbits well defined. Antennules lodged in fossettes. Antennæ short and devoid of an acicle. The external maxillipeds have the ischium and merus flattened and usually fitted neatly to the buccal area. First pair of legs always chelate; the following pairs always simple. The abdomen is small, shorter than the carapace, and flexed against the ventral surface of the thorax. The abdomen of the male is smaller than that of the female and bears but one or two pairs of appendages near the base; abdominal appendages in the female more numerous than in the male and used for holding the ova. Tail fin absent.

The subdivisions of the Brachyura can usually be recognized by their general form. The Maioidea, or spider crabs, have the carapace narrowed in front where it is generally produced into a rostrum. The Cancroidea usually have a transverse carapace with a 
narrow front. The Grapsoidea may commonly be recognized by their quadrate form, but there are many forms which do not exhibit this character. The Oxystomata may be distinguished by the form of the buccal area which is narrowed in front. None of these marks, however, are absolutely diagnostic, for it is difficult to separate the groups by single characters.

\section{Subtribe MAIOIDEA; or OXYRHYNCHA.}

Carapace narrowed in frout and usually furnished with a rostrum Branchial regions large; hepatic regions small. Buccal area quadrate. Epistoma usually large. The afferent channels open behind the pterygostomian regions in front of the chelipeds; efferent channels opening at the sides of the endostome. Antenuules longitudinally plicated. Palp of the maxillipeds situated at the summit or antero-internal angle of the merus. Verges of the male on the coxæ of the last pair of legs.

This group includes the species known as the "spider crabs" and "sharp-nosed crabs." They are generally of sluggish habit and many of the species become overgrown with sea-weeds and other foreign growths, which make them difficult to detect in their natural habitat.

The classification followed is that given in Miers' revision of this group. ${ }^{1}$

\section{Legion MAIINEA.}

Basal joint of the antennæ well developed and inserted beneath the eyes, usually occupying a great part of the infra-orbital space.

\section{Family INACHID $A$.}

Orbits not defined. Preorbital and postorbital spines generally well developed. Eyes not retractile, or retractile against the sides of the carapace. Basal antennal joint generally slender. Rostrum simple or bifid. Fingers of the chelie never excavated at the tips.

1 Jour. Linn, Soc., London, Vol. XIY, 1879. 


\section{Subfamily LEPTOPODIIN Æ.}

Eyes slender, not retractile, laterally projecting. Preocular and postocular spines small or wanting. Basal joint of the antenna slender throughout its length. Rostrum usually simple.

\section{Genus Podochela St.}

Carapace depressed, narrowly triangular, strongly produced in front. Gastric region narrow, tumid, rostrum short, entire, triangular or arcuate. Eyes long and laterally projecting. Basal antennal joint narrow, with a median, longitudinal groove; the apex narrow and not dentate. Flagellum slender and visible from above. Merus of external maxillipeds much shorter than the ischium, the apices obtuse or produced, the inner one more or less incised; palp joined at the summit of the merus. Epistome very long. Chelipeds of moderate size; merus curved, the margins ciliated. Ambulatory legs very long, subprehensile, and often furnished with a more or less cheliform hand. Dactyls of chelipeds very slender and often hooked, those of the remaining legs falciform. Sternum of female deeply concave and surrounded by a laminate margin. First abdominal segment quite large, second, third, and fourth very short; the last two or three segments fused together.

Type.-P. grossipes $\mathrm{ST}_{\mathrm{T}}$

\section{Podochela Hemphillii (Lock.)}

Microrhynchus Hemphillii Lockingtox, Proc. Cal. Acad. Sci., Vol. VII, 1877, p. 30.

Inachoides (Microrhynchus) Hemphillii Lockington, l. c., p. 75.

Podochela tenuipes Rathbur MI., Proc. U. S. Nat. Mus., Vol. XVI, 1893, p. 224.

Podochela Hemphillii Rathbox M., Proc. U. S. Nat. Mus., Vol. XXI, 1898, p. 569.

Carapace pyriform; gastric region prominent, rounded, and bearing tufts of curved setro; hepatic regions tumid, bearing two pointed tubercles, the larger one above and in front of the smaller; cardiac region separated by shallow grooves from the branchial and bearing a prominent elevation; branchial regions flattened or tumid. Rostrum triangular, acute, and bearing two double rows of curved setæ above; it varies considerably in length, being sometimes broadly and sometimes narrowly triangular. The area between the two projecting rims of the orbits is concave. There is no tooth at the posterior margin of the orbit, but there may be a small one a short distance behind it. Eye-stalks constricted at the middle and 
bearing a few setæ at the subacute tip. Basal antennal joint with a longitudinal ridge on its posterior half or two-thirds with a groove on either side. Ischium of maxillipeds with a shallow, longitudinal groove; merus narrower than ischium, the internal angle produced, and the surface strongly concave from side to side. Chelipeds in the male robust; merus incurved and having an outer spiny ridge; carpus with a posterior spine on the upper side; hand oblong, incurved, palm inflated, fingers gaping at the base and meeting along the distal half, or two-thirds of their length; there are generally several small, spiny projections on the surface of the hand, which are more conspicuous along the edges, especially the lower. In the female the chelipeds are smaller and more slender, the hands subcylindrical, and the fingers nearly straight. Legs very long and slender, and furnished with tufts of long setæ, those on the upper side being curved; dactyls slender, falciform, those of the first pair about onethird the length of the propodi, and a little more slender but not more curved than the others; in the two posterior pairs the dactyls are about one-half the length of the propodi. Abdomen of the male six-jointed from the fusion of the last two joints; first two joints visible from above; the first joint is much longer but not so wide as the second; the second, third, and fourth joints decrease successively in width but are of nearly equal length; the fifth is longer than the preceding and the sixth is oblong, rounded at the tip, and much longer than any of the others; the sides of the abdomen behind the second joint are concave and at the middle of each joint there is a conical protuberance, the last joint bearing traces of two. In the female the abdomen is large and rounded and composed of five joints from the fusion of the last three; it fits closely over the thin, laminate rin which encloses the greater portion of the sternum. As the sternum and the ventral surface of the abdomen. are both hollowed out, there is thus formed a quite capacious chamber for holding the ova.

Length of male $26 \mathrm{~mm}$; breadth $17 \mathrm{~mm}$; length of first ambulatory legs $60 \mathrm{~mm}$.

San Diego (Lockington); Santa Catalina Island, dredged August, 1893! Off Cape St. Lucas and Gulf of California (Miss Rathbun); Magdalena Bay, Lower California! I have seen Lockington's specimens from the latter locality, and Miss Rathbun's types of tenuipes from Catalina.

\section{Subfamily INACHIN Æ.}

Eyes slender and retractile. Basal antennal joint usually slender throughout, not narrowing distally. Preocular spine often wanting; postocular distinct. Rostrum often bitid or two-spined. 


\section{Genus Oregonia Dana.}

Carapace flattened, not spinose. Spines of rostrum long, slender, and contiguous. Ambulatory legs of moderate leugth, the penultimate joint similar to the preceding oue, not dilated and compressed. Near Eurypodius.

Type.-O. gracilis Daxa.

\section{Oregonia gracilis Dana.}

Oregonia gracilis Daxa, Am. Jour. Sci. (2), Vol. XI, 1851, p. 270; Crust. U.S. Expl. Expd., Part I, 1S52, p. 106, Pl. III, fig. 2. Stimpson, Journ. Bost. Soc. Nat. Hist., Vol. VI, 1857, p. 456. BATE, in Lord's Naturalist in Vanconver's Island, Vol. II, 1866, p. 269. Lockington, Proc. Cal. Acad. Sci., Vol. VII, 1877, p. 74. Surтн, Rept. Prog. Geol. Sur. Canada, 1S78-9, B, p. 209. Newconbe, Bull. Nat. Hist. Soe. Brit. Col., 1893, p. 21. Rathbon M., Proc. U. S. Nat. Mus., Vol. XVII, 1894, p. 59.

Oregonia hirta DaNA, Am. Jouru. Sci. (2), Vol. XI, 1851, p. 270; Crust. U.S. Expl. Expd., Part I, 1852, p. 107, Pl. III., fig. 3. Stimpson, 1. c., p. 456. Lockington, 1. c., p. 75. Whiteaves, Can. Nat. (2), Vol. VIII, 1878, p. 471.

Oregonia longimana Bate, Proc. Zool. Soc. London, 1864, p. 663; Ann. Nat. Hist. (3), Vol. XV, 1865, p. 487; in Lord's Nat. in Vancouver's Is., Vol. II, 1866.

Carapace subtriangular, more or less setose and roughened by minute prominences. Median, cardiac, and branchial regions tumid. The rostral horns may exceed the breadth of the interorbital space. Postorbital spines slender, acute, inclined forwards, and situated some distance behind the orbit. A prominence on the anterior side of the eye peduncle. The septum separating the antennulary fossettes is produced into a spine. Maxillipeds setose, the ischium produced forward into a rounded process at the antero-internal angle. Chelipeds rather slender, the merus subcylindrical and roughened with minute tubercles; carpus rounded; hand long, slender, somewhat compressed, the margins obtuse; fingers slender, smooth, incurved. Legs subcylindrical and decreasing in length posteriorly; dactyls slightly exceeding one-half the length of the propodi and terminated by loug, corneous claws.

Behring Sea to Oregon (Rathbun); Vancouver Island (Bate, Smith); Puget Sound (Dana); northern California!

Like many other maioid crabs, this species varies greatly as regards the development of the chelipeds in 
the male. Speaking of a collection of specimens of this species from Vancouver's Island, Professor Smith says: "The series of specimens is sufficient to show that the two forms described by Dana are sexual and belong to one species, the gracilis being based on the adult male, and the hirta on the two forms of the female. In the characters of the rostral spines and the rest of the carapax, all the larger males before me agree with the description and figures of gracilis, while in the same characters the females agree with hirta, and the smaller males are more or less intermediate between the two forms. But among the females themselves there are two forms: all the adult and fertile specimens having the abdomen very broad, and nearly orbicular, while in the other specimens (most of them small, but some of them as large as the smaller of those with orbicular abdomens) the abdomen is much narrower and elliptical, as shown in Dana's fig. $3, b$. The smaller of these latter females are, perhaps, merely immature individuals, but the larger are truly dimorphic, sterile females, such as are found in many genera of Brachyura, and here, as in most similar cases, the larger of the sterile individuals show considerable approach to the males in the form of the carapax, etc.

"In the largest male before me the merus of the chelipeds reaches nearly or quite to the tip of the rostrum, and, in this respect, agrees with Bate's 0 . longimana, though the chelipeds are not nearly twice as long as the carapace, if the rostrum is, as it is usually, included in the length."

\section{Genus Erileptus Rath.}

Carapax broadly triangular; regions well defined, convex. There is a postorbital and also a supraorbital spine. Rostrum slender and simple. Abdomen and sternum granulate; abdomen six-segmented. Basal 
antennal joint with a slender spine at the antero-external angle. Merus of external maxillipeds with a prominent, obtuse lobe on the inner margin. Chelipeds very long, slender, subcylindrical; fingers short, arched. Ambulatory legs very slender, shorter than the chelipeds; dactyls almost straight.

Type.-E. spinosus Rath.

\section{Erileptus spinosus Rath.}

Erileptus spinosus Rathbux M., Proc. U. S. Nat. Mus., Vol. XVI, 1893, p. 227.

Carapace spiny; gastric region with two spines arranged transversely and a median spine behind; branchial region having a long spine with a smaller spine in front of it and two spines on the margin; hepatic region with a maroinal spine; a spine on the cardiac area and a small spine on the orbital arch. Rostrum slender, with spinulous margins. A small postorbital spine some distance behind the eye. Chelipeds long, granulated; merus with a spine above; haud slender, distally widened. A spine on the first abdominal segment.

Length $10 \mathrm{~mm}$.; width $6 \mathrm{~mm}$.; length of cheliped $28 \mathrm{~mm}$.

Off San Diego, California, 36 fathoms (Miss Rathbun). I have not seen this species.

\section{Subfamily ACANTHONYCHIN Æ.}

Eyes small, immobile, or only partially retractile; basal antennal joint enlarged at base and narrowing distally. Rostrum bifid, or two-spined.

\section{Genus Epialtus Milne-Edw.}

Rostrum flattened, bifid or two-spined. Preocular spine present or absent. Eyes more or less mobile. Legs of moderate length, the penultimate joint not dilated and compressed. Flagellum of the antennæ concealed beneath the rostrum. The carapace is smooth or slightly tuberculated and the margins are not incised.

Type.-E. bituberculatus MILre-EDw. 


\section{Epialtus productus Randall.}

Epialtus productus RANDaLL, Jour'h. Acad. Nat. Sci. Phila., Vol. VIII, 1839, p. 110. Gibbes, Proc. Am. Ass. Adv. Sci,, 1850, p. 173. Dana, Crust. U. S. Expl. Expd., Part I, 1852, p. 133, Pl. VI, fig. 2. Stiurson, Journ. Bost. Soc. Nat. Hist., Vol. VI, 1857, p. 457. Lockivgton, Proc. Cal. Acad. Sci., Vol. VII, 1877, p. 77. Rathiun R., The Fisheries of the U. S., Sec. I, 1884, p. 778, Pl. CCLXVIII. Newcombe, Bull. Nat. Hist. Soc. Brit. Col., 1893, p. 22 . Ortmans, Zool. Jahrb. Abth. f. Syst., Bd. VII, 1894, p. 42. Rathbon M., Proc. U. S. Nat. Mus., Vol. XVII, 1894, p. 68.

Carapace smooth and not distinctly areolated. Rostrum deeply notched, the inner margins of the horns slightly concave, the outer convex. There is a small, triangular preorbital tooth; postorbital tooth small. The margin between the postorbital and the large tooth at the antero-lateral angle is concave and transverse. About midway between the antero-lateral tooth and the posterior Inargin of the carapace there is a large tooth pointing forwards and ontwards; the sides of the carapace in front of the posterior teeth are nearly parallel; the posterior margin has a strong convexity in the middle. Chelipeds stouter, and except in old males, shorter than the first ambulatory legs; carpus carinate on the outer side; hand long and narrow, palm oblong, subcarinate above, becoming inflated with age; fingers slender, bent downward and curved inward, the inner margins dentate and contiguous throughout their length, except in old males in which they may become more or less gaping at the base. Ambulatory legs successively decreasing in length posteriorly, penultimate joints subcarinate, dactyls slender, spinulous below, and terminating in sharp, slender claws. Abdomen of the female subelliptical, the last joint triangular.

Color reddish to olive brown mottled with small, round spots of a darker hue.

Length of ordinary specimen from tip of rostral horns $78 \mathrm{~mm}$; width between antero-lateral horns $58 \mathrm{~mm}$.

\section{Alaska to Lower California.}

This species is abundant on our coast; it is commonly known as the "kelp crab" from the fact that it is usually found on kelp the color of which it closely resembles. There may be small, setose tubercles on the median region of young specimens, but they disappear with age, and there are two rows of curved setæon the upper side of the rostrum which persist for a longer 
time. Old specimens are almost entirely devoid of hairs or setre of any kind.

\section{Epialtus Nuttallii Rand.}

Epicaltus Nuttallii Raxdall, Jonru. Acad. Nat. Sci. Phila., Vol. VIII, 1839, p. 109, P1. Irr. Gibbes, Proc. Am. Ass. Adv. Sci., 1850, p. 173.

Stimpson, Journ. Bost. Soc. Nat. Hist., Vol. VI, 1857, p. 458. Lockixgton, Pros. Cal. Acad. Sci., Vol. VII, 1877, p. 77. Rathbun M.,

Proc. U. s. Nat. Mus., Vol. XXII, 1898, p. 572.

Épialtus (Antilibinia) Nuttallii Rathbur M., 1. c., Vol. XVII, 1894, p. 69.

Carapace ovate, couvex, smooth, and not areolated. Rostrum promineut, depressed, flattened above, and having a small triangular notch at the tip. No preorbital tooth; postorbital small. The two teeth on the sides of the carapace are much smaller than in E. productus, and the margins between them are corvergent anteriorly. The chelipeds are very similar to those of productus. Ambulatory legs subcylindrical; dactyls stouter than in the preceding species.

Southern California_Santa Barbara! Santa Catalina Island! San Diego! Ballenas Bay, Lower California (Rathbun).

\section{Genus Mimulus St.}

Carapace flattened, more or less pentagonal; antero-lateral margin laminate and cut by a narrow fissure into two closely approximate lobes. Rostrum short, bifid, and horizontal. Orbits incomplete below, but furnished above with a preorbital and postorbital spine. Eyes not concealed when retracted. Merus of the external maxillipeds short, the external angle obtuse, the internal angle incised; outer margin of the exognath dilated. Hand of the chelipeds much compressed and subcarinate. The propodi of the ambulatory legs have a setose tooth near the middle of the inferior margin. First pair of ambulatory legs exceeding the others.

Type.-M. foliatus $\mathrm{ST}$.

\section{Mimulus foliatus St.}

Mimulus folicatus Strupsos, Ann. N. Y. Lyc. Nat. Hist., Vol. VII, 1860, p. 200, Pl. III, fig. 1. A. Milse-Edwards, Crust. Miss. Sci. au Mex., Pt. V, p. 145, Pl. XVIII, fig. 4.

Pugettia (Mimulus) foliatc Newconbe, Bull. Nat. Hist., Soc. Brit. Col., 1893, p. 22.

Pugettic folicatc Rathbur MI., Proc. U. S. Nat. Mus., Vol. XVII, 1894, p. 72 .

Carapace flattened and marked with several undulations; median region tumid and bearing two small, obsolescent tubercles in front of which there 
may be two rows of curved setæ. Rostral horns flattened, with convex outer margins, the notch between them narrowly triangular and setose. On the upper side of the rostrum there are two double rows of curred setæ. Preorbital tooth large, triangular, acute; postorbital small and pointing obliquely downwards, and separated by a fissure from the preorbital tooth. The lateral expansions of the carapace are a little reflexed, and the margin behind the incision is nearly twice the length of that in front. The antero-lateral and postero-lateral angles are wide and the latter are somewhat produced. An obsolescent tubercle on the posterior part of the branchial region. Pterygostomian regions with several blunt teeth. Peduncle of antennæ about reaching tip of rostrum. Chelipeds of the male large, the merus rough and cristate on the inner margin; carpus with a lamina on the inner margin; hand oblong, the fingers bent downward and curved inward, somewhat gaping near the base but distally dentate. In the females and young males the chelipeds are relatively smaller, the crista on the merus not so prominent, and the fingers contiguous and dentate along the entire inner margin. First pair of ambulatory legs longer and a little more compressed than the others, the penultimate joint subcarinate above. Abdomen of female elliptical, seven jointed. Abdomen of the male widest at the third segment, narrowing rapidly to the fifth which is about equal to the sixth; last segment narrow and longer thau the preceding one.

Color a dull purplish, the legs crossed by light bands.

Length of carapace $30 \mathrm{~mm}$; greatest width $32 \mathrm{~mm}$.

Found among rocks at low tide. Alaska; British Columbia (Rath.); northern to southern California! Mexico (Milne-Edwards).

\section{Genus Pugettia Dana.}

Rostrum two-spined. The margin of the carapace behind the eyes is produced into an alate expansion behind which it is somewhat constricted. The upper surface of the carapace is furnished with spines or tubercles. The flagella of the antennæ are not entirely covered by the rostrum. The ambulatory legs are slender and do not have the penultimate joint dilated and compressed. The preocular spine is large and the eyes are mobile.

Type.-P. gracilis DaNA.

\section{Pugettia Richii Dana.}

Pugettia Richii Daxa, Am. Jour. Sci. (2), Vol. XI, 1851, p. 268; Crust. U.S. Expl. Expd., Part I, 1852, p. 118, Pl. IV, Fig. 4. Stimpsox, Journ. Bost. Soc. Nat. Hist., Vol. VI, 1857, p. 457. Lockington, Proc. Cal. Acad. Sci., Vol. VII, 1877, p. 76. Miers, Challenger Reports, Vol. XVII, 18S6, p. 40. Newconbe, 13ull. Nat. Hist. Soc. Brit. Col., 1893, p. 21. Rathbun M., Proc. U. S. Nat. Mus., Vol. XVII, 1894, p. 71. 
Carapace ovate, tuberculated; median region tumid and furnished with four tubercles, the three anterior of which are nearly abreast (the anterior one a little in advance of the others); two donble rows of curved setro in front of the lateral tubercles, and two similar rows on the rostrum. Cardiac and intestiual regions each furnished with a tubercle; two tubercles ou the branchial region, the one situated before the other. Rostrum prominent, the horus divaricate and convex above, the triangular notch between them hairy. Supraorbital tooth acute and directed forward, ontward and upward. Postorbital tooth acute and triangular. Behind the postorbital there is a large, rather slender tooth which projects laterally, the tip curving forwards. At the postero-lateral angle of the carapax there is a prominent, pointed tubercle, in front of which the margin is furnished with curved setæ. A spine on the sub-brauchial region below the middle of the space between the postero-lateral tubercle and the large, curved tooth. Pterygostomian region with three to six small teeth. Surface of the ischium of the maxillipeds plane, but sometimes bearing a trace of a longitudinal groove; exognath not grooved. Chelipeds large in the adult males, much shorter and more slender in the females; the merus bears a few tubercles on the upper side but no carina; the inner side may become strongly ridged in adult males, but it is generally rounded in young males and females; the carpus has two or three cristæ which become more prominent in old males; hands compressed, the upper edge acute; fingers shorter than the palm, and gaping at the base in old males. Legs subcylindrical and crossed by light-colored bands; merus and propodus not crested. Color reddish.

Length $1_{\frac{7}{1} \frac{7}{6}}$ in., width across gastric region between tips of horns $\frac{15}{16} \mathrm{in.}$; across cardiac region $1 \frac{1}{15}$ in.

British Columbia; Puget Sound; entire coast of California! San Diego! Found at low tide.

\section{Pugettia gracilis Dana.}

Pugettia gracilis Dasa, Am. Journ. Sci. (2), Vol. XI, 185̃l, p. 268; Crust. U. S. Expl. Expd., Part I, 1852, p. 117, Pl. IV, fig. 3. Strimpsox, Journ. Bost. Soc. Nat. Hist., Vol. VI, 1857, p. 456. Miers, Challenger Reports, Vol. XVII, 1886, p. 40. Newcombe, Bull. Nat. Hist. Soc. Brit. Col., 1893, p. 22. Rathbes M., Proc. U. S. Nat. Mus., Vol. XVII, 1894, p. 69.

Pugettia Lordii Bate, Proc. Zool. Soc. London, 1864; Ann. Nat. Hist. (3), Vol. XV, 1865, p. 486; in Lord's Nat. in Vau. Is., Vol. II, 1866, p. 265. Pugettic quadridens var. gracilis ORTMAxs, Zool. Jahrb. Abth. f. Syst., Bd. VII, IS94, p. 43. 
Closely allied to P. Richii. Carapace lyrate to broadly ovate, convex, tuberculated, the tips of the tubercles often furvished, as in the preceding species, with tufts of setæ. The number and position of the tubercles are the same as in Richii except that there may be a few small tubercles, or tufts of setæo on the branchial regions. The cardiac tubercle may become scarcely visible in old specimens. Median region tumid, the middle anterior tubercle small, and sometimes obsolete. Curved setæo as in Richii. Rostrum less prominent than in the preceding species; supraorbital tooth broader than in Richii, separated by an incision from the postorbital tooth which is triangular, acute and points more nearly forwards than it does in the preceding species. Behind the postorbital is a broadly triangular tooth, the posterior margin of which is nearly longitudinal. Postero-lateral tubercle smaller than in Richii. Ischium of the maxillipeds with a longitudinal groove; exognath also grooved. Spine on sub-branchial regions small or wanting. Merus of the chelipeds with a prominent irregularly dentate carina on the upper side; carpus cristate. Legs subcylindrical, the merus and propodus more or less carinated above, especially in the anterior pairs.

Length $28 \mathrm{~mm}$; width between antero-lateral horns $16.25 \mathrm{~mm}$; between postero-lateral horns $20.5 \mathrm{~mm}$.

Alaska! Vancouver Island, Puget Sound, Oregon, northern California! Farallon Islands! southern California. Found at low tide.

This species may easily be distinguished from Richii by the lyrate form of the carapace, the form of the large tooth behind the postorbital, by the crest on the merus of the chelipeds and the subcarinate joints of the ambulatory legs.

\section{Pugettia Dalli Rath.}

Pugettia Dalli Rathbon M., Proc. U.S. Nat. Mus., Vol. XVI, 1893, p. 232.

A small species closely allied to $P$. Richii, the young of which it closely resembles. Carapace subtriangular, tuberculated; the tubercles on the gastric region are disposed as in the preceding species, but the anterior and posterior tubercles are small or obsolescent; there is a tubercle on the intestinal region and a prominent one on the cardiac; a small tubercle on the branchial region in the position of the posterior one in the other species. Rostrum much resembling that of Richii, but with slightly more slender horns. Supraorbital tooth acute; postorbital flattened and pointing obliqueiy downwards; the tooth behind the postorbital is more slender 
and spine-like than in Richii, and does not curve so strongly forwards, Postero-lateral tubercle acute, prominent, spine-like. No sub-branchial spine. Ischium of the maxillipeds grooved. Chelipeds of the male large, the merus with an irregular carina on the upper and inner margins; carpus strongly carinated on the inner and upper margins and irregularly ridged on the outer side; hand large, wider than in Richii, the upper edge acute; fingers strongly gaping at base, meeting only at the tips, a tooth on the movable one near the base. Chelipeds in the female smaller than in the male, hand narrower, the fingers not gaping at the base. Legs longer and more slender than in specimens of Richii of equal size; the joints not carinated.

The females have a broader carapace than the males and the gastric region is more tumid, and the branchial regions more distinctly areolated.

Length of carapace in male $11 \mathrm{~mm}$.; width without spines $6.5 \mathrm{~mm}$.; length of cheliped $13 \mathrm{~mm}$; width of hand $3.3 \mathrm{~mm}$.

Santa Catalina Island, San Diego (Miss Rathbun); San Pedro! off San Diego!

Described from specimens received from Miss Rathbun.

\section{Subfamily DASYGYINÆ}

Eyes short, completely retractile. Postocular spine large. Basal antennal joint considerably enlarged throughout its length. Rostrum simple or bifurcated. Preocular spine present or absent. Legs generally slender.

\section{Genus Dasygyius Rathbun.}

(Microrhynchus Bell and Neorhynchus MLine-Edwards preoc.)

Rostrum short and simple. No preocular spine. Merus of maxillipeds cordiform. Anterior legs in the male small. Ambulatory legs of moderate length. .

\section{Dasygyius tuberculatus (Lock.)}

Inachus tuberculatus Lockington, Proc. Cal. Acad. Sci., Vol. VII, 1877, p. 30 .

Microrhynchus (Inachus) tuberculatus Lockington, 1. c., 1877, p. 64.

Neorhynchus mexicanus Rathbus M., Proc. U. S.. Nat. Mus., Vol. XVI, 1893, p. 233.

Dasy:gyius tuberculatus Rathbox M., l. c., Voi. XXI, 1898, p. 570. 
Carapace subtriangular and furnished with tubercles and granulations; a tubercle on the posterior portion of the tumid median region; a large, pointed tubercle on the cardiac, and a smaller one near the posterior margin of the carapace; branchial regions with several small tubercles; tubercles on the sides of the carapace prominent. Rostrum acute. Postocular spine pointing obliquely forwards and a little exceeding the eyes. Basal antennal joint with its outer edge produced forwards into a spine and its lower side furnished with a longitudinal ridge which is nearer the inner than the outer edge. Chelipeds in the male rather stout, the outer edge of the merus furnished with small tubercles and coarse granulatious; inner edge of the carpus coarsely granulated; palm of the hand inflated and having a short row of small tubercles on the proximal portion of the outer surface near the middle line; fingers slender, sulcate. Legs long and slender. In the male the first abdominal segment is large and bears a large spine-like tubercle; the second segment is short and bears a smaller tubercle; the third segment is the widest and bears three rounded elevations in a transverse row; behind the third segment the abdomen tapers rapidly to the fifth, which is but little wider than the succeeding one; the last segment is subtriangular and fused with the one before it. In the female the first segments are short and furnished with small median tubercles. In the male the sternum is coarsely granulated, and on the segment which bears the chelipeds there is a pair of transverse, granulated ridges.

The measurements of Lockington's specimens which I have had the opportunity of examining are as follows:

\begin{tabular}{|c|c|c|c|}
\hline & Length. & Breadth. & $\begin{array}{l}\text { Length of first } \\
\text { ambulatory leg }\end{array}$ \\
\hline Male ... & $.75 \mathrm{in}$ & .55 in & ... 1.55 in. \\
\hline Female. & $.56 \mathrm{in}$ & .38 in & .94 in. \\
\hline
\end{tabular}

The rostrum varies much in length; in old males it is often produced into a sort of spine; in females and young males it.is often quite broadly triangular.

San Diego! Magdalena Bay (Lockington)! Gulf of California (Rathbun)! Panama Bay (Rathbun).

I have seen the types of both tuberculatus and mexicanus. 


\section{Genus Loxorhynchus St.}

Rostrum two-spined, the spiues coalescent at the base and then divergent. Preocular and postocular spines prominent. Orbits interrupted by a deep sinus above and below. Basal antennal joint enlarged, subquadrate, and having a laterally projecting spine at the outer angle. A spine beneath the postorbital near the base of the first joint of the antenna. Epistome large and subtrapezoidal. Ischium of the maxillipeds produced forwards at the antero-internal angle; merus entire at the distal end. Ambulatory legs subcylindrical, of moderate length, and decreasing in length posteriorly. The carapace is spiny and the abdomen seven-jointed.

T'ype.-L. grandis $\mathbf{S T}$.

\section{Loxorhynchus grandis St.}

Loxorhynchus grandis Stimpson, Proc. Bost. Soc. Nat. Hist., Vol. VI, 1857, p. S5; Journ. Bost. Soc. Nat. Hist., Vol. VI, 1857, p. 452, P1. XIX, fig. 1, Pl. XXII, fig. 1; Ann. N. Y., Nat. Hist., Vol. VII, 1859, p. 49. Rathbox M., Proc. U. S. Nat. Mus., Vol. XVII, 1894, p. 74.

Carapace very broadly ovate, inflated and covered with small, conical tubercles of nearly equal size. Rostrum a little longer than broad, much deflexed, the horns couvex above and below and separated for a little more than half their length. Preorbital spine large, often more or less double pointed; postorbital spine subconical, acute. Chelipeds in the male large, tuberculated; hand oblong, palm inflated, the edges rounded. Ambulatory legs subcylindrical, sparingly tuberculated, the antepenultimate joints. grooved above; a small tubercle near the end of the merus. Abdomen of the male contracted behind the third segment, the three following segments of nearly equal width (the fourth slightly wider at the base); fifth and sixth segments nearly equal and longer than the third or fourth; last joint. subtriangular, but rounded at the tip. Abdomen of female broadly elliptical, all the joints free; the joints increase in length from the third to the sixth; last joint broadly rounded, much broader than long. Thoracic sternum transversely grooved. Carapace covered with short hairs.

Stimpson gives the following measurements of a female:-

Length of carapace...................... 5.55 in.

Width of carapace...................... 4.54 "

Length of first pair of legs ................. 4.90 "

Length of second pair of legs ............... 6.45 "

Length of last pair of legs ................. 4.75 "

Farallon Islands! near San Francisco! Santa Catalina Island! San Pedro! San Diego! 


\section{Loxorhynchus crispatus St.}

Loxorhynchus crispatus Stimpson, Journ. Bost. Soc. Nat. Hist., Vol. VI, 1857, p. 453, Pl. XXII, figs. 2, 3 and 4. Ortmann, Zool. Jahrb. Abth. f. Syst., Bd. VII, 1894, p. 45. Rathbon M., Proc. U. S. Nat. Mus., Vol. XVII, 1894, p. 74 .

Carapace rather narrowly triangular, somewhat flattened, not nearly so wide and inflated as in the preceding species. Some of the tubercles are much larger than others, the principal ones being located as follows: a tubercle on the cardiac region which is connected with a tubercle on the intestinal by a prominent ridge; two tubercles on the branchial regions, the anterior of which is somewhat nearer the middle line; a large tubercle on the hepatic region; a tubercle on the anterior and one on the posterior portion of the median region; a tubercle on either side of the anterior median tubercle; a row of small blunt tubercles on the median region extending to each rostral horn. Rostrum longer than broad, not so much depressed as in grandis, and having more divergent horns which are separated for more than half the length of the rostrum. Preorbital spine prominent, subconical. Chelipeds rather slender; merus with three or four small tubercles on the upper side; carpus with small tubercles; hand slender, slightly wider at the base, margins rounded. Ambulatory legs rather short, the first pair in the female usually longer than the chelipeds, merus grooved above; dactyls shorter and stouter than in grandis, about one-half the length of the propodi. Abdomen of the male similar to that of the preceding species, but the last joint is narrower. The chelipeds in the male are much longer than in the females, and in old specimens they become enormously lengthened.

\section{Farallon Islands! San Francisco Bay! Monterey,} Santa Barbara! San Pedro! San Diego! San Miguel Island (St.).

The carapace in this species is covered by a very dense, even coating of peculiar, short, thick hairs-if hairs they may be called-which are so closely crowded together that no spaces are left between them. In some places they are less than twice as long as thick. Along the sides of the carapace and on the median region there are the usual curved setæ, but on the legs and abdomen there are numerous large, clavate setæ; between these and the short thick setæ there are, however, all stages of transition. 
These crabs are generally found so thickly covered with foreign growths, such as hydroids, seaweeds, bryozoans and sponges, that, in their natural environment, they are scarcely recognizable as crabs at all.

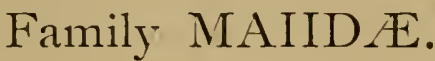

"Eyes retractile within tolerably well-defined orbits which are often more or less incomplete below, or marked with open fissures in their upper and lower margins. Basal antennal joint always more or less enlarged."

\section{Subfamily MAIINÆ.}

"Carapace usually subtriangular. Rostrum well-developed. Anterior legs in the male usually enlarged; fingers not excavate at the tips."

\section{Key to THE GENeRA.}

Rostrum vertically compressed and notched. Orbits shallow.

Ambulatory legs compressed and flattened ............ Chioncecetes. Ambulatory legs subcylindrical.

Second joint of antenna dilated. Carapace lyrate.........Hyas.

Second joint of antenna slender, subcylindrical. Carapace

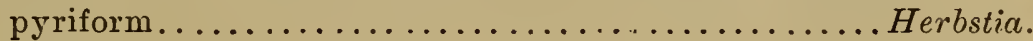

Rostrum composed of two more or less divergent spines. Orbits deep.

First ambulatory legs very long. Rostral horns slender.

Carapace spiny ........................ Hyastenus.

First ambulatory legs moderate.

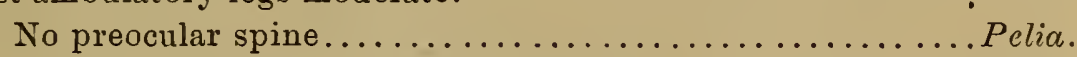

A preocular spine, Rostrum flattened ..............Scyra.

\section{Genus Hyas Leach.}

Rostrum bifid, flattened, the horns by a narrow fissure. Orbits shallow and open abore, with a fissure above and below. Eyes partially visible from above when retracted. No preocular spine. Basal antenual joint much enlarged, the second moderately dilated, the third narrow. Carapace flattened, more or less tuberculated, but not spiny. Ambulatory legs subcylindrical and of moderate length.

Type.-Hyas araneus. 


\section{Hyas lyratus Dana.}

Hyas lyratus Dana, Am. Journ. Sci. (2), Vol. XI, 1851, p. 268; Crust. U.S. Expl. Expd., Part I, 1852, p. 86, Pi. I, fig. 1. Strmpson, Journ. Bost. Soc. Nat. Hist., Vol. VI, 1857, p. 450. Lockington, Proc. Cal. Acad. Sci., Vol. VII, 1877, p. 64. Miers, Challenger Reports, Vol. XVII, 1886, p. 47. Rathbun M., Proc. U. S. Nat. Mus., Vol. XVI, 1893, p. 72, Pl. III. Newcombe, Bull. Nat. Hist. Soc. Brit. Col., 1893, p. 20.

Carapace lyrate and furnished with blunt tubercles. Median region tumid, and generally furnished with two elevations, one near the middle and one behind; post-median region prominent, pustulate or roughened; cardiac region furnished with a subconical elevation; branchial regions elevated at the middle and crossed by a more or less evident line of rounded tubercles. Rostrum shorter than the width of the interorbital space, the cleft between the horns narrow. A tooth on the anterior margin of the optic peduncle. Basal antennal joint with a few small teeth on each margin and a prominent, smooth tubercle at the antero-external angle; second joint dilated and almost entirely visible from above. A small tooth on the first joint below the articulation of the second. Maxillipeds granulated. Behind the eyes is an alate expansion, the anterior and posterior margins of which are generally nearly parallel, outer margin long and a little concave; anterior angle acute; a small tooth near the base of the convex posterior margin of this expansion, behind which the side of the carapace is quite deeply indented. Behind the alate expansion the margin of the carapace is furnished with a row of small tubercles. Merus of the chelipeds with a few small tubercles, which are more prominent at the angles; hands narrow, compressed, smooth or granulated, the upper margin compressed and roughened by small tubercles; fingers nearly smooth. The abdomen of the male is widest at the second and third segments, behind which the sides run nearly parallel to the last joint, which is distally truncated and over twice as broad as long. Abdomen of the female broadly elliptical, the joints increasing in length from the second to the last.

Locality of specimens described:-

$56^{\circ} 40^{\prime} \mathrm{N}$. $169^{\circ} 20^{\prime} \mathrm{W}$. 43 fms. $56^{\circ} 58^{\prime} \mathrm{N}$. $170^{\circ} 09^{\prime} \mathrm{W}$. 25 " 2 spms. $56^{\circ} 34^{\prime} \mathrm{N}$. $170^{\circ} 17^{\prime} \mathrm{W}$. 62 “

1 “"

2 “"

This species ranges from the extreme end of the Aleutian Islands to Puget Sound, whence it was first reported by Dana. 


\section{Genus Hyastenus White.}

Carapace subpyriform, convex, smooth, tuberculated, or spiny. Spines of rostrum long, slender, and diverging from the base. Preocular spine small or obsolete. Eyes small, the peduncles slender and completely retractile within the small orbits which have a lateral aspect, and a fissure, or hiatus in the upper and lower margins. Basal antennal joint large; flagellum usually exposed and visible from above at the sides of the ros. trum. Ambulatory legs elongated, subcylindrical and unarmed, the first pair usually much the longest. Abdomen of the male seven-jointed.

This genus is divided by Miers into two subgenera, which, however, "are connected together by numerous gradations." The one, Hyastenus, is characterized by having few or no spines on the carapace and by the absence of a spine at the external angle of the basal antennal joint. The other, Chorilia, has the carapace spiny and the basal antennal joint is furnished with a spine. Hyastenus (Chorilia) longipes is the type of the latter subgenus.

\section{Hyastenus (Chorilia) longipes (Dana).}

Chorilia longipes DaNA, Am. Journ. Sci. (2), Vol. XI, 1851, p. 269; Crust. U. S. Expl. Expd., Part I, 1852, p. 91, Pl. I, fig. 5. Stimpson, Journ. Bost. Soc. Nat. Hist., Vol. VI, 1857, p. 455. Lockington, Proc. Cal. Acad. Sci., Vol. VII, 1877, p. 69. Whiteaves, Can. Nat. (2), Vol. VIII, 1878, p. 470. RathвoN M., Proc. U. S. Nat. Mus., Vol. XXI, 1898, p. 572 .

Hyastenus (Chorilia) longipes MIers, Journ. Linn. Soc. London, Vol. XIV, p. 658; Proc. Zool. Soc. London, 1879, p. 27.

Hyastenus japonicus Mrers, Proc. Zool. Soc. London, 1879, p. 27, Pl. I, fig. 2; Challenger Reports, Vol. XVII, 1886, p. 56, (fide Rathbun M.). Hyastenus longipes Miers, Challenger Reports, Vol.XVII, p. 56. RathbuN M., Proc. U. S. Nat. Mus., Vol. XVI, 1893, p. 85, Pl. VII. Newcombe, Bull. Nat. Hist. Soc. Brit. Col., 1893, p. 20.

Carapace pyriform, inflated, and covered with sharp spines of unequal size. Median region tumid, with two median spines and a row of three spines on either side, the posterior one being the largest and situated a little behind the middle of the interval between the two spines on the middle line; a prominent spiue on the tumid hepatic region; several small 
spines on the cardiac region and a small spine or tubercle near the posterior end of the intestinal. The spines on the branchial regions are numerous and variable, but there is usually a more prominent spine near the middle. Pterygostomian regions with a row of teeth or spines. Rostrum long, the horns nearly straight, pubescent and divergent. Preorbital spine prominent, acute, postorbital acute and pointing obliquely downwards. Basal antennal joint armed at its external angle with a slender spine, the margin behind which is armed with two smaller spines. There may be a few minute spinules at the apex of the eye-stalk. Merus of the chelipeds furnished with small tubercles, which are more prominent on the angles; carpus furnished with small tubercles on the outer side, which are more or less plainly arranged in three or four rows; hands long, slender, compressed, palm subcarinated above, nearly smooth, and generally having a small tubercle on the outer side near the articulation; fingers long and slender. Dactyls of the slender ambulatory legs long and nearly straight. Abdomen of the male tapering from the third segment, the last joint longer than broad and rounded at the tip. Abdomen of the female broadly elliptical, the joints increasing in length from the third to the last. In some females, either immature or sterile, the abdomen is narrowly elliptical and not nearly so wide as the thoracic sternum. The legs and many parts of the body are covered with a short pubescence.

Miss Rathbun, who has carefully studied a large number of specimens of this species, gives the following account of its variations: "This species ranges from $57^{\circ}$. north latitude, off Kadiac, Alaska, to $32^{\circ}$ north latitude, off San Diego, Calif., and in depth from 27 to 603 fathoms. It exhibits wide variations from Dana's types, especially in more southern latitudes, where, as a rule, the carapace is very much swollen at the branchial regions, making the width much greater in proportion to the length; the second and third joints of the antennæ are much more slender; the hepatic region is furnished with a sharp spine; and, lastly, the tubercles of the carapace are much more numerous and some of them spinous. These characteristics, if uniform, would be specific, but the two extremes intergrade to such an extent as to render impossible even a varietal separation. The broad form is, with one exception, confined 
to deep water; the typical longipes ranges from 27 fathoms in the north to 456 in the south. Variations exist in specimens from the same locality; for example: The broad forms may possess a hepatic spine or a tubercle; the antennal joints are narrow in some individuals and wide in others. Occasional specimens of the narrow form have a sharp hepatic spine. *** The width of the typical form ranges from 0.71 to 0.8 of its length; of the wider form from 0.82 to 0.9 of its length; the length being measured from between the bases of the cornua."

\section{Genus Pelia Bell.}

Carapace subpyriform. Rostrum composed of two divergent spines which are united at the base. Orbits small, with a lateral aspect and with a superior and an inferior marginal hiatus; the upper orbital margin smooth and devoid of a preorbital spine. Eyes small, with slender peduncles. Basal antennal joint elongated, its distal portion visible from above at the sides of the rostrum; flagellum well developed. Merus of the maxillipeds with a notch at the articulation of the palp, legs of moderate length; first ambulatory legs much longer than the others; merus compressed, acute above, dactyls not denticulated below.

T'ype.-P. pulchella BELL.

Near Pisoides, but having a narrower basal antennal joint, the distal end of which is visible from above. Differs from Pisa in the absence of spines on the under side of the dactyls.

\section{Pelia tumida (Lock.)}

Pisoides (?) tumidus Lockington, Proc. Cal. Acad. Sci., Vol. VII, 1877, pp. 30 and 67.

Microphrys tumidus MIERs, Challenger Reports, Vol. XVII, 1886, p. 83.

Carapace pyriform, rounded, tumid, covered with pubescence, but entirely devoid of spines. Median region rounded, smooth, much elevated, and furnished with a small rounded tubercle at the summit; branchial regions inflated; cardiac region with a small rounded elevation. Rostrum depressed, nearly one-half the length of the carapace and bifurcated for 
about half its length, the horns narrow, divergent, and slightly upturned at the tip. No preorbital tooth; postorbital small. Antero-lateral margin entire. Basal antennal joint considerably longer than wide and devoid of teeth with the exception of the one at the antero-external angle, which is plainly visible from above; tip of the peduncle reaching but beyond the apex of the notch between the rostral horns, not nearly reaching the tip of the rostrum as in pacifica; flagellum rather long. Merus of the maxillipeds distally truncated. Chelipeds unarmed; merus not nearly reaching the tip of the rostrum; hand oblong, inflated, the edges obtuse and parallel; fingers widely gaping, a tubercle on the inner margin of the dactyl near the base. Ambulatory legs compressed, pubescent, the margins furnished with a thick fringe of stiff setr; dactyls sharply curved at their sharp, corneous tips.

Length $12 \mathrm{~mm}$.; width $8 \mathrm{~mm}$; length of first ambulatory leg $12 \mathrm{~mm}$.

Described from a single male specimen from Magdalena Bay, Lower California, preserved in the museum of the California Academy of Sciences. This specimen is, I believe, one that is mentioned by Lockington, l. c., p. 67.

San Diego (Lockington), Magdalena Bay, Lower California (Lockington)! Santa Catalina Island!

\section{Pelia pacifica Milne-Edw.}

Pelia pacifica A. Milne-Edwards, Miss. Sci. au Mex., Vol. I, Pt. V, 1875, p. 73, Pl. XVl, fig. 3. Rathbun M., Proc. U.S. Nat. Mus., Vol. XVI, 1894, p. 90; and Vol. XXI, 1898, p. 573.

Near mutica, but having a shorter and wider carapace with the prominences on the gastric and cardiac regions more pronounced. Rostrum short and stout. Basal antennal joint shorter and wider than in mutica.

Length of carapace $9 \mathrm{~mm}$; width $7 \mathrm{~mm}$.

Bay of Panama (M.-Edw.); Gulf of California, Magdalena Bay, Lower California! San Diego, Santa Catalina Island (Miss Rathbun).

\section{Genus Herbstia Milne-Edw.}

Carapace broadly triangular or subpyriform, tuberculated or spinose. Rostrum short, the horns acute, vertically compressed, and dilated at the base. Orbits shallow, with or without a preorbital spine. Eyes short and 
not entirely concealed when retracted. Basal antennal joint moderately dilated and armed with an antero-exterual spine, the distal portion not entirely covered by the rostrum. Merus of maxillipeds distally truncated and not produced at the onter angle. Ambulatory legs rather slender, subcylindrical, and of moderate length; dactyls neariy straight, acute. Abdomen in the male seven-jointed.

This genus is divided into two subgenera as follows:

Herbstia: Inferior margin of orbit not dentate. Ambulatory legs not spinose.

Herbstiella ST.: Inferior margin of orbit armed with a tooth or spine. Merus of ambulatory legs spinose.

The subgenus Herbstiella to which our species belong is almost exclusively West American.

\section{Herbstia (Herbstiella) camptacantha St.}

Herbstia parvifrons Stimpson, Ann. N. Y. Lyc. Nat. Hist., Vol. VII, 1860, p. 185 (not $H$. parvifrons RANDALL).

Herbstiella camptacantha Stimpson, 1. c., Vol. X, 1871, p. 94.

Herbstia camptacantha A. Milne-Edwards, Miss. Sci. au Mex., Vol. I, Pt. V, p. 78, Pl. XVIII, fig. 3.

Herbstia (Herbstiella) camptacantha Miers, Journ. Linn. Soc. London, Vol. XIV, 1879, p. 655; Challenger Reports, Vol. XVII, 1886, p. 49.

Rathion M., Proc. U. S. Nat. Mus., Vol. XVI, 1893, p. 79.

Fisheria depressa Lockington, Proc. Cal. Acad. Sci., Vol. VII, 1877, p. 72.

Carapace ovate, punctate, much flattened, and armed above with several small tubercles. Median region tumid, separated from the branchial and cardiac regions by deep sulci and armed, in front, with four tubercles in a transverse line, the middle tubercles separated from each other by about twice the distance that they are from the lateral ones; a median, rounded tubercle on the posterior portion of the median area; three, or four small tubercles on the cardiac region and about five on each branchial region; two tubercles, in a transverse line, on the intestinal area. Rostral horns flattened and divergent, forming more than one-half the length of the rostrum. Preorbital spine acute; there is a small spine, or tooth, on the margin of the orbit above the postorbital tooth, while below it there is a spine on the inferior orbital margin. The spine at the antero-external angle of the basal antenual joint is prominent, and on the margin behind it there are two spines, the posterior of which is sometimes reduced to a small, blunt tooth. Beside the postorbital tooth the antero-lateral margin is furnished with about five spines, and there are several smaller ones 
on the postero-lateral margin. Pterygostomian region armed with several spines. Chelipeds in the adult male long; merus long, subcylindrical, armed above with numerous spines and usually having a few spines at the distal end of the lower margin; carpus with the outer surface tuberculated; haud large, smooth, elongated and compressed; fingers widely gaping. Ambulatory legs pubescent; merus armed above with numerous spines, and with one or more spines near the distal end of the lower margin; carpus with one or more spines above; propodi long, slender, subcylindrical, unarmed, and about twice the length of the dactyls.

Cape St. Lucas, Acapulco, Mexico (St.); Mazatlan, Magdalena Bay! Lower California; San Diego! Santa Catalina Island! San Pedro! San Clemente Island!

This species differs from parvifrons in having the hand entirely devoid of spines. The chelipeds in the male become greatly elongated with age; the hand becomes narrower, the spines on the lower side of the merus become obsolete, while those on the upper side become blunt. In one specimen from Port Escondido the chelipeds were two and one-half times the length of the carapace; the merus was a little longer than the carapace and the hand about one-third longer. The carapace is covered with a pubescence which disappears to a greater or less extent with age.

I have seen the two specimens of Fisheria depressa. referred to by Lockington as "No. 21" (1. c., p. 73).

\section{Herbstia parvifrons Randall.}

Herbstia parvifrons Randall, Journ. Acad. Nat. Sci. Phila., Vol. VIII, 1839, p. 107. Gibbes, Proc. Am. Ass. Adv. Sci., 1850, p. 170. Strmpson, Journ. Bost. Soc. Nat. Hist., Vol. VI, 1857, p. 451.

I have not seen this species nor do I believe that anything has been found since Randall's specimen was taken which answers to his description, which is quoted below.

"Corpore depresso, in latere spinoso, pedibus spinosis, leviter dilatatis, manibus løvigatibus, dactylis apice serrulatis." 
"Body flattened above, punctured, somewhat hairy; sides spinous, especially anteriorly; rostrum very short; feet spinous above; hand of the anterior pair with only a few very small spines at the base; pincers without teeth, except toward their apices, where for one-third of their whole length they are hollowed out on their prehensile side, so that when closed they become interlocked at their extremities by means of their serratures. Length of carapax about one inch."

One specimen from Western America.

\section{Genus Chionœcetes Kröyer.}

Carapace broad, depressed, more or less tuberculated or spinose. Rostrum short, flattened and notched, not depressed. Orbits shailow, open above so that the short, thick eye-peduncles are visible from above when retracted. No preorbital spine; postorbital present. Basal antennal joint very narrow, with a terminal spine; second and third joints not dilated; flagellum short. Ambulatory legs more or less compressed and of moderate length. Abdomen seven-jointed.

Type.-C. opilio (FABR.).

\section{Chionœcetes opilio ( $F a b r$.}

Cancer phalangium O. FABRICIUS, Fauna Groenlandica, 1780, p. 234.

Cancer opilio O. FABRICIUS, Danske Vid. Selsk. Skr. nye Saml., Band. III, 1788 , p. 181, plate.

Chioncecetes opilio KRöYER, Naturh. Tidskrift (1), 2, 1838, p. 249.

Chioncecetes behringianus Stimpsox, Proc. Bost. Soc. Nat. Hist., Vol. VI, 1856, p. 84; Journ. Bost. Soc. Nat. Hist., Vol. VI, 1857, p. 449.

For further references see Rathbun, Proc. U. S. Nat. Mus., Vol. XVI, 1893, p. 74.

This species extends from Greenland to Behring Sea and down the west coast of America as far as British Columbia, and may, not improbably, occur within our limits. The carapace is flattened and covered with wart-like tubercles. There is no deep depression separating the branchial regions. The ambulatory legs are shorter, stouter and less spiny than in the next species. 


\section{Chionœcetes Tanneri Rath.}

Chionocetes Tanneri Rathbun M., Proc. U. S. Nat. Mus., Vol. XVI, 1893, p. 76, Pl. IV, figs. 1-4; and Vol. XXI, 1898, p. 573. NеwсомвE, Bull. Nat. Hist. Soc. Brit. Col., 1893, p. 19.

Carapace a little wider than long, with the postero-lateral angles broadly rounded; branchial regions tumid and produced laterally, concealing the lateral margins. The carapace is covered with spines, instead of wart-like tubercles as in opilio, the most conspicuous of which are arranged in more or less irregular rows. A nearly transverse row of tubercles on the branchial regions, which, near the side of the carapace, curves around and runs obliquely forwards towards the orbit. Posterior margin of the carapace spinulous; above the outer portions of this margin there begins another row of spinules, which is continued around the sides of the carapace, the spines becoming smaller anteriorly; at the bend in the row of spines on the branchial regions there begins another row of spines which runs forward to the anterior portion of the buccal area, the spines becoming smaller and more thickly set anteriorly, where they gradually spread out into a small patch of minute, irregularly placed tubercles next to the buccal area. An irregular row of spinules across the anterior portion of the median area. The upper margins of the orbit and the outer sides of the rostrum are spinulous. A small elevated patch of spinules on the cardiac region, in front of which is a deep depression, separating the branchial regions, which is rather narrow behind, but widens anteriorly, and divides into two broad depressions extending either side of the median area. Rostral horns upturned, narrower than in opilio, the notch between them more prominent. Basal antenual joint spinulous below. Maxillipeds more or less spinulous, and not reaching the anterior margin of the buccal area. Chelipeds spinulous, small in the female; hand narrow; fingers long. Legs spiny, becoming smoother toward the tips. A transverse spinulous or granulated ridge in front of the abdomen, in front of which the sternum is excavated. First two or three joints of the abdomen with a transverse spinulous or granulated ridge.

The largest specimen in the series studied by Miss Rathbun gave the following measurements:

Length from base of rostral horns ............ $119 \mathrm{~mm}$.

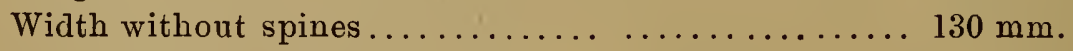

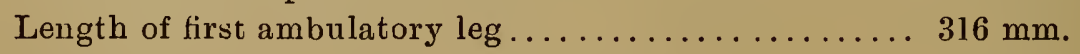

Length of merus of first ambulatory leg.......... $134 \mathrm{~mm}$.

Miss Rathbun's table of measurements of 18 specimens shows that in the smaller specimens the length more 
nearly equals the breadth than in the larger ones. In one case the length and breadth were each $32 \mathrm{~mm}$., but in no case was a specimen longer than broad.

Deep water from Behring Sea to southern California; 29 to 1,625 fathoms (Miss Rathbun).

This and preceding species seen and compared.

\section{Genus Scyra Dana.}

Carapace subpyriform, tuberculated, but not spinose. Rostrum composed of two flattened horns. Orbits small, with a fissure above and below, the lower and sometimes the upper one being open. Preorbital spine present. Basal antennal joint rather narrow, with a small spine at the antero-external angle, the two following joints compressed and not concealed by the rostrum. Merus of the maxillipeds distally truncated. Chelipeds in the male well developed, the hand compressed and carinated above; fingers acute. Legs moderately long, subcylindrical, the first pair not greatly exceeding the others in length; dactyls short and acute. Abdomen seven-jointed.

Type.-S. acutifrons Daxa.

\section{Scyra acutifrons Dana.}

Scyra acutifrons DAxA, Am. Journ.:Sci. (2), Vol. XI, 1851, p. 269; Crust. U. S. Expl. Expd., Part I, 1852, p. 95, P1. II, fig. 2. Strimpson, Journ. Bost. Soc. Nat. Hist., Vol. VI, 1857, p. 455. Lockingron, Proc. Cal. Acad. Sci., Vol. VII, 1877, p. 69. Miers, Journ. Linn. Soc. London, Vol. XIV, 1879, p. 663; Challenger Reports, Vol. XVII, 1886, p. 62. Sмiтн, Rep. Prog. Geol. Surv. Canada, 1878-9, B, p. 210. Rathbon M., Proc. U. S. Nat. Mus., Vol. XVI, 1893, p. 88. Newcombe, Bull. Nat. Hist. Soc. Brit. Col., 1893, p. 21.

Scyra (sp. undet.) Whiteates, Can. Nat. (2), Vol. VIII, p. 471; (see Smith 1. c.).

Carapace pyriform and furnished with rounded tubercles. Median region tumid and separated from the cardiac and branchial regions by a conspicuous depression; an acute tubercle near the center of the median region, behind which is a larger and more obtuse tubercle. Branchial regions tumid and bearing a large, projecting tubercle, in front of which is an elevated prominence which may bear several small tubercles, though it is often smooth. A large tubercle on the cardiac and a smaller one on the intestinal region. Rostrum short, the horns ovate-lanceolate. Two 
spines or teeth on the outer margin of the basal antennal joint behind the one at the anterior angle. Preorbital spine acute. Pterygostomian regions with several rounded teeth. Chelipeds of the male large, the merus subcylindrical (somewhat flattened below), and strongly pustulate, especially at the angles; the carpus is pustulate and may have several ridges on the outer side; hand long, narrow, compressed, the palm below the wide carina often inflated; fingers deflexed and, in old males, gaping at the base, in which case there is generally a large tooth near the base of the dactyl. Legs subcylindrical, more or less pubescent, the propodi sulcate on either side; dactyls considerably shorter than the propodi and furnished with sharp, corneous tips. The third, fourth, fifth and sixth abdominal segmeuts in the male are of nearly equal length; the seventh is longer than broad and rounded at the tip; the abdomen tapers most at the third and fourth segments, the fifth and sixth being of subequal width.

Length of carapace: male................ $35 \mathrm{~mm}$.

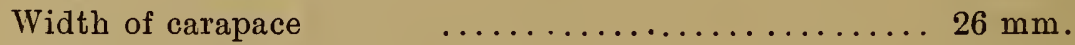

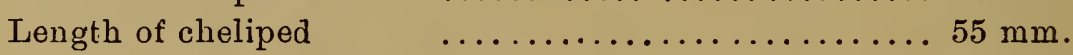

Length of first ambulatory leg. .............. $40 \mathrm{~mm}$.

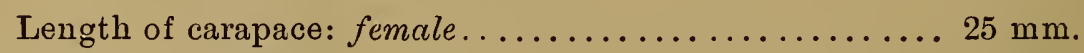

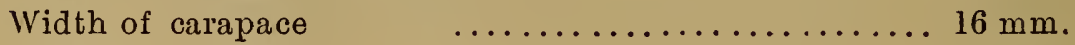

Length of cheliped $\quad \ldots \ldots \ldots \ldots \ldots \ldots \ldots \ldots .28 \mathrm{~mm}$.

Alaska, British Columbia, Oregon, Farallon Islands! southern California! Santa Catalina Island! San Diego!

The individuals of this species vary considerably with age. In the old males the tubercles on the carapace are rougher and more prominent, the posterior tubercle on the branchial region projecting over the sides of the carapace; the horns of the rostrum become much widened at the base; and the chelipeds are much larger. In the females the tubercles on the carapace are smoother, those on the median region being small or obsolescent.

\section{Family PERICERID危.}

Eyes retractile within the small, circular, and well defined orbits which are never incomplete as in the Maiidø. Basal antennal joint well developed, and constituting the greater part of the inferior wall of the orbit. 


\section{Subfamily PERICERINÆ.}

Carapace more or less triangular. Rostrum well developed. Second joint of the antenna not dilated. Chelipeds with the fingers acute at the tips.

\section{Genus Libinia Leach.}

Carapace orbiculate-triangular, convex, spinose. Preocular spine distinct. Rostrum of moderate length and emarginate only at the apex. Eye-peduncles short. Basal antennal joint moderately enlarged, the flagellum visible from above. Legs of moderate length. Abdomen of male and female seven-jointed.

T'ype.-L. emarginata LEACH.

\section{Libinia emarginata Leach.}

Libinia emarginata Leach, Zool. Misc. (2), 1815, p. 129. RathbuN R., The Fisheries of the U.S., Sec. I, 1S84, p. 778, Pl. CCLXIX, fig. 4. Rathbun M., Proc. U. S. Nat. Mus., Vol. XV, 1892, p. 235, Pl. XXXI, fig. 2. Ortuarr, Zool. Jahrb. Abth. f. Syst., Bd. VII, 1894.

Libinia canalaculata SaY, Journ. Acad. Nat. Sci. Phila., Vol. I, 1817, p. 76. MILle-Edwards, Hist. Nat. Crust., Vol. I, 1834, p. 300. Streets, Proc. Acad. Nat. Sci. Phila., Vol. XXII, 1870, p. 105.

Libinia affinis Ravdall, Journ. Acad. Nat. Sci. Phila., Vol. VIII, 1839, p.

106. Strmpsox, Journ. Bost. Soc. Nat. Hist., Vol. VI, 1857, p. 455.

StREets, 1. c.

For further references, see Rathbun M., $l$. $c$.

Carapace suborbicnlar, much inflated, and covered with numerous smali, pointed tubercles. Median region with four or five median tubercles, besides mauy others. Hepatic regious not clistended, aud furnished with three quite promiuent spines, the upper one forming the first of a series of five spines (or tubercles) which extends backward upon the branchial regions. A row of five tubercles behind the median region, making nine or ten median tubercles in all. Rostrum short, triangular, the apex furnished with a very small emargination.

Length of male specimen $95 \mathrm{~mm}$; breadth $90 \mathrm{~mm}$.; length of cheliped $160 \mathrm{~mm}$; of hand $84 \mathrm{~mm}$.; of first ambulatory leg $158 \mathrm{~mm}$.; of last leg $98 \mathrm{~mm}$.

Atlantic Coast from Maine to Florida; "Western America" (Randall).

The foregoing description is based on specimens from Wood's Holl, Massachusetts. I have seen no specimens 
of this species from the Pacific Coast, and know of none having been found there since Randall's specimen was taken. Mr. Streets, whose words imply that he has seen Randall's type, says that this species "is undoubtedly nothing more than the young of canaliculata. That it is so will be evident to anyone who will take the trouble to compare them closely. It agrees with $L$. canaliculata in every respect excepting size."

\section{Legion PARTHENOPINEA.}

" Basal antennal joint very small and imbedded with the next joint in the narrow hiatus between the front and the inner suborbital angle; the infra-ocular space being mainly occupied by the lower wall of the orbit."

\section{Family PARTHENOPID $Æ$.}

Characters of the legion of which it is the only family. The species of this family are often markedly triangular in form; the carapace is usually angular and provided with conspicuous depressions separating the regions. In the characters of the antennæ and also in several other points, the Parthenopida approach the Cancroid Brachyura.

\section{Genus Heterocrypta St.}

Carapace triangular, transverse, the lateral margins greatly produced and concealing the ambulatory legs. A conspicuous depression separating the gastric from the cardiac and branchial regions. Rostrum simple. A strongly marked ridge on the pterygostomian regions. Chelipeds greatly developed, trigonal. Posterior margin of the carapace not produced, as in Cryptopodia.

\section{Heterocrypta occidentalis (Dana).}

Cryptopodia occidentalis DaNA, Am. Journ. Sci. (2), Vol. XVIII, 1854, p. 430, fig. in text. Strmpson, Journ. Bost. Soc. Nat. Hist., Vol. VI, 1857, p. 458. Grbbes, Proc. Elliott Soc. Nat. Hist., Charleston, S. C., Vol. I, 1859, p. 36 . A. Milne-Edwards, Miss. Sci. an Mex., Vol. I, Pt. V, p. 169.

Lambrus frons-acutis Lockington, Proc. Cal. Acad. Sci., Vol. VII, 1877, p. 31 . 
Carapace broadly triangular; rostrum triangular, subacute, not depressed. Median region narrow, the flattened upper surface bounded by two granulated ridges, which converge to a point behind. Cardiac region furnished with a three-sided, pyramidal elevation, the edges of which are usually granulated. Postero-lateral regions large, and furnished with an S-shaped, granulated crest, which extends from near the posterior end of the median region to the acute lateral angles of the carapace; in front of the anterior bend of this crest there is a pair of minute tubercles. Antero-lateral margin straight or slightly concave in front, convex near the middle, the posterior portion passing outwards and backwards, arching over the legs; the teeth on the anterior part are small and irregular, but they become larger posteriorly, where they are furnished with secondary denticles. Postero-lateral margins transverse; posterior margin not produced over the abdominal segments. Outer portion of the orbit with a superior and an inferior fissure. Ischium of the maxillipeds smooth, the antero-internal angle produced; merus small, the surface concave and bearing near the middle a prominent tooth. Chelipeds long, trigonal; the sides of the merus convex, the edges sharply granulate to dentate; carpus with three or fonr granular lines; hand about as long as the merus, the angles prominent and dentate and the sides concave; pollex short, deflexed; dactyl short, but longer than the pollex, and when closed its outer margin is nearly at right angles to the long axis of the hand. Ambulatory legs compressed, strongly carinated above; dactyls narrow, strongly sulcate, and corneous-tipped. Color reddish.

Length $18 \mathrm{~mm}$; breadth $28 \mathrm{~mm}$.; length of cheliped $50 \mathrm{~mm}$.

Monterey (Dana) ; Santa Catalina Island (Lock.)! This species is quite common in Avalon Harbor, Santa Catalina Island. I have examined a specimen in the California Academy of Sciences which I feel confident is Lockington's type of frons-acutis.

\section{Genus Leiolambrus Milne-Edw.}

Carapace subtriangular, smooth, with no tubercles or spines on the upper surface. The median and cardiac regions are not separated from each other by a deep depression, but are limited on either side by longitudinal sulci. Front short, truncated, and armed with a small, median tooth. The antero-lateral margins are denticulated and the posterior margin is furnished with teeth or spines. Lateral angles of the carapace prominent and acute. Orbits well defined and furnished with a fissure in the upper and lower margins. Antennules obliquely plicated. Ischium of the maxillipeds produced forward at the antero-internal angle; outer 
angle of the merus rounded. A ridge on the pterygostomian regions. Chelipeds trigonal, the angles dentate. Ambulatory legs slender, compressed; dactyls slender, depressed.

Type. - L. punctatissimus (OwEN).

\section{Leiolambrus punctatissimus (Owen).}

Parthenope punctatissima Owes, Zool. Beechy's Voyage, Crust., 1839, p. 81, Pl. XXIV, fig. 4. Stimpson, Journ. Bost. Soc. Nat. Hist., Vol. VI, 1857, p. 458. Lockington, Proc. Cal. Acad. Sci., Vol. VII, 1877, p. 78. Leiolambrus punctatissimus A. MILne-Edwards, Miss. Sci. au Mex., Vol. I, Pt. V, pp. 148 and 159.

Carapace smooth, convex, minutely punctate; the median and cardiac. regions forming a nearly continuous longitudinal elevation, bounded on either side by a conspicuous, longitudinal depression. Front truncated, having a small, median tooth, behind which the upper surface is marked with a short, longitudinal groove. Postorbital angle acute. Antero-lateral margins long, slightly arcuated, and furnished with teeth which become very small toward the anterior end. The sides of the carapace are produced into a prominent, triangular tooth. Two teeth on the posterior margin near the middle line; external to these a pair of larger marginal teeth; the margins between the external pair and the lateral angles of the carapace are concave. The whole posterior margin of the carapace is marked with a delicate, raised, jagged line; another fine raised line running upon the branchial regions from the external tooth of the posterior margin. Maxillipeds smooth, the ischium slightly narrowed distally, the antero-internal angle produced forward into a rounded lobe; merus broadly rounded at the antero-external angle and produced below the articulation of the palp. Chelipeds large; merus with the angles denticulated, the anterior edge bearing several rough teeth; carpus with the angles denticulated, the outer margin acute and dentate; hand longer than the merus, the margins denticulated, the upper margin upturned near the end; pollex nearly longitudinal and almost straight, the inner margin dentate; dactyl curved and provided on the external portion of the base with two converging, denticulated ridges which meet and form a crest on the distal portion. Ambulatory legs smooth, compressed, and subequal in length; dactyls slender, lanceolate, longer than the propodi, and flattened in a plane at right angles to that of the preceding joints.

Locality of specimen described, lat. $27^{\circ} 45^{\prime} \mathrm{N}$., lon. $110^{\circ} 45^{\prime} \mathrm{W}$; 20 fathoms.

Length of carapace......................... $7.25 \mathrm{~mm}$.

Width of carapace.................... $9.5 \mathrm{~mm}$.

Length of hand...................... $7 \mathrm{~mm}$. 


\section{Subtribe CYCLOMETOPA, or CANCROIDEA.}

Carapace generally broader than long, wide and regularly arcuated in front, rarely quadrate or suborbicular in form; rostrum wanting. Epistome short, transverse. Antenmules longitudinal or transverse. Palp of the maxillipeds joined to the apex or inner angle of the merus. Branchire nine, the efferent branchial channels as in the Maioidea. Verges of the male in the coxi.

\section{Section CANCRINI Ortmann.}

Carapace rounded or widened, a dentate antero-lateral margin sharply. marked off from a postero-lateral margin devoid of teeth. Front with several teeth, one of which is median. Antennules longitudinal or. oblique.

\section{Genus Cancer $L$.}

Carapace transverse, subelliptical, indistinctly areolated. Antero-lateral margins regularly arcuated and armed with ten teeth. Front narrow, cut into five teeth or lobes. Eye-peduncles short; orbits small, with two fissures in both upper and lower margins. Antennules longitudinal, or nearly so. Basal antennal joint somewhat enlarged and united with the front, thus excluding the short flagellum from the orbit. Merus of the maxillipeds distally truncated and not produced at the antero-external angle. Chelipeds subequal, the hand generally costate on the outer surface.

\section{Key to THE SPECIES.}

Carapace not undulated; size small .............. gracilis.

Carapace undulated, large species.

Autero-lateral teeth distant, the posterior one the largest........................... magister. Antero-lateral teeth contiguous.

Front flattened and produced............ productus.

Front not flattened nor produced ........ antennarius.

\section{Cancer productus Randall.}

Cuncer productus Raxdalı, Journ. Acad. Nat. Sci. Phila., Vol. VIII, 1839, p. 116. Dasa, Crust. U. S. Expl. Expd., Part I, 1852, p. 156, Pl. VII, fig. 3. Stimpson, Proc. Cal. Acad. Sci., Vol. I, 1856, p. 88; Journ. Bost. Soc. Nat. Hist., Vol. VI, 1857, p. 461. Bate, in Lord's Nat. in Vancouver's Island, Vol. II, 1866, p. 269. Lockington, Proc. Cal. Acad. Sci, Vol. VII, 1877, p. 95. Snith, Rep. Prog. Geol. Sur. Canada, 1879, B, p. 207. Rathbun R., The Fisheries of the U. S., Sec. 1, 1884, p. 771, Pl. CCLXII. Ortmans, Zool. Jahrb. Abth. f. Syst., Bd. VII, 1894, p. 425. Calman, Amn. N. X. Acad. Sci., Vol. XI, 189S, p. 262.

Platycarcinus productus (iribees, Proc. Am. Ass. Adv. Sci., 1850, p. 177. Cancer perlatus Stmipson, Proc. Cal. Acad. Sci., Vol. I, 1856, p. 88. 
Carapace usually wide, undulated above. Hepatic regions depressed. Front flattened, produced into fire, generally obtuse teeth which lie in the same horizontal plane, the outermost pair not more widely separated from the inner pair than these are from the median tooth. Superior margin of the orbit between the two fissures not produced into a tooth, as in antennarius; external orbital tooth small, the next one behind it rounded; succeeding teeth becoming larger and more acute posteriorly, the last tooth, in adult specimens, being the largest. Between the teeth the margin of the carapace is marked with short, closed fissures. The tooth on the lower margin of the orbit small or absent. Flagellum of the antennules considerably shorter than the width of the front. Merus of the maxillipeds obliquely truncated at the distal end and notched on the inner side at the articulation of the palp. Carpus of the chelipeds with a large tooth at the antero-internal angle and a smaller one behind the upper hinge joint; the outer surface is roughened with several irregular prominences; hand with a double row of tubercle-like teeth on the upper edge and four or five granulated costæ on the outer surface, the upper ones of which are the most obscure; fingers stout and tipped with black, the dactyl not cristate above. Ambulatory legs nearly naked, except the dactyls which are slender and a little longer than the propodi. Terminal abdominal segment in the female nearly equilaterally triangular, the sides concave. In the male this segment is more narrowly triangular than in the other sex. Color dark reddish above; below a dirty white.

Length of large specimen, male............. $85 \mathrm{~mm}$.

Breadth of large specimen, male..............

Length of small specimen, female ............ $22.5 \mathrm{~mm}$.

Breadth of small specimen, female............. $33.5 \mathrm{~mm}$.

Dr. Stimpson has given a table of measurements of specimens of different sizes and sex, showing that the males are wider than the females and the old males relatively wider than the young ones. The proportion of length to breadth was found to vary from $1: 1.30$ in a male $.99 \mathrm{in}$. in length to $1: 1.63$ in a male of $2.95 \mathrm{in}$. in length. The young of this species differ in many respects from the old specimens. The carapace is much flatter and smoother, and ornamented above with numerous longitudinal, colored lines which entirely disappear in the adult. The teeth of the front are represented by five subequal crenulations. The teeth on the antero-lateral margin are much less distinct, being 
represented on the anterior portion by low crenulations which become more acute behind. In the adult the posterior tooth may curve forwards but not so sharply as in antennarius. Secondary denticles are nearly obsolete. The granules on the carapace are of unequal size, being generally larger and sharper on the median region. In the females the carapace is generally more convex than in the males.

Queen Charlotte Island (Smith), Vancouver Island (Bate), Puget Sound (Dana), Oregon. Common on the entire California coast to Lower California.

\section{Cancer antennarius St.}

Cancer antennarius Strupson, Proc. Cal. Acad. Sci., Vol. I, 1856, p. 88; Journ. Bost. Soc. Nat. Hist., Vol. VI, 1857, p. 462, PI. XVIII. LockIngton, Proc. Cal. Acad. Sci., Vol. VII, 1877, p. 96. Sмiтh, Rep. Prog. Geol. Sur. Canada, 1879, B, p. 207. Rathbun R., The Fisheries of the U.S., Sec. 1, 1884, p.771, Pl. CCLXIII. Miers, Challenger Reports, Vol. XVII, 1886. Ortwann, Zool. Jahrb. Abth. f. Syst., Bd. VII, 1894, p. 425 .

Platycarcinus recurvidens Bate, Proc. Zool. Soc. London, 1864; Ann. Nat. Hist. (3), Vol. XV, p. 488; in Lord's Nat. in Vancouver's Island, Vol. II, 1866.

Carapace undulated, smooth, widest at the penultimate antero-lateral tooth, the granulations on the surface minute and even. Front not produced, the three median teeth separated from the outermost pair which is the largest. The middle tooth is smaller than those on either side and situated a little below them. A tooth on the superior margin of the orbit between the two fissures. The tooth on the basal antennal joint projects further forward than the lateral tooth of the front and there is quite a prominent tooth on the inferior orbital margin just external to it. The postorbital is the smallest of the antero-lateral teeth but is relatively much larger than in productus. The teeth of the antero-lateral margin are large and have the tips sharp (except when worn) and curved forward; on the margins of the teeth, especially the anterior margin, there are usually small, sharp, secondary denticles. There are but nine large antero-lateral teeth, the tenth being probably represented by a small projection behind the last large tooth. Flagellum of the antennæ usually long, generally 
exceeding the width of the front. Distal margin of the merus of the maxillipeds nearly transverse and gently convex; inner margin notched. Chelipeds stout; carpus with a stout tooth at the antero-internal angle and a smaller tooth behind the superior hinge joint; the external surface is smooth in old specimens but roughened, granulated and pubescent in younger ones. The hand is longitudinally costate on the external surface in young specimens but the costr disappear with age; the fingers are smooth and tipped with black. Ambulatory legs very hairy or nearly naked; the dactyls pubescent and a little stouter than in productus.

Length of carapace, male ................. $76 \mathrm{~mm}$.

Breadth of carapace, male...................

Length of carapace, female................ $73 \mathrm{~mm}$.

Breadth of carapace, female................. $107 \mathrm{~mm}$.

The young of this species are relatively much less wide than the adults and have the carapace and appendages thickly covered with hair. The hair on the upper surface disappears with age and in old specimens the appendages may become nearly naked. The postorbital tooth in young specimens is fully as large as those behind it. This is a well marked species and may easily be distinguished from the other species on our coast by the sharply recurved antero-lateral teeth.

Queen Charlotte Island (Smith), Vancouver Island, Oregon, northern to Lower California! Common.

\section{Cancer magister Dana.}

Cancer irroratus Randall, Journ. Acad. Nat. Sci. Phila., Vol. VIII, 1839, p. 116.

Cancer magister Dana, Proc. Acad. Nat. Sci. Phila., Vol. VI, 1852, p. 7\$; Crust. U. S. Expl. Expd., Part I, 1852, p. 151, Pl. VII, fig. 1. Sirmpson, Proc. Cal. Acad. Sci., Vol. I, 1856, p. 88; Journ. Bost. Soc. Nat. Hist., Vol. VI, 1857, p. 458. Cooper, Rep. Expl. Sur. Pac. Ocean, Vol. XII, 1860, p. 387. Lockington, Proc. Cal. Acad. Sci., Vol. VII, 1877, p. 94. Sмiтh, Rep. Prog. Geol. Sur. Canada, 1878-9, B., p. 206. Rathbun R., The Fisheries of the U. S., Sec. I, 1884, p. 770, Pl. CCLXI.

Metacarcinus magister A. Milne-Edwards, Ann. Sci. Nat. (4), T. XVIII, 1862, p. 33, and (5), T. I, 1864, p. 67; Nouv. Archiv. Mus. Hist. Nat. Paris, T. I, 1865, p.202, Pl. XIX, fig. l. OrtmanN, Zool. Jahrb. Abth. f. Syst., Bd. VII, 1894, p. 424 . 
Carapace gently convex, undulated, and covered with small granulations which are larger on the summits of the prominences. Two or three curved rows of light colored spots on the antero-lateral regions. Front not produced, the three median teeth small, the middle one being slightly the largest and projecting further forward than the others; outermost pair larger than the others, not reaching so far forwards, and separated from them by a cousiderable interval. No tooth on the superior orbital margin. Basal antemnal joint large, its pointed extremity projecting much further forward than the outer tooth of the front. A small tooth on the inferior margin of the orbit just external to the basal antennal joint. Anterolateral margin armed with ten distant teeth which decrease in size and become more closely set anteriorly; the teeth are triangular in shape and the margin between them is denticulated or sharply granulated; the posterior tooth is the largest of the series, its anterior margin is generally transverse and its posterior margin contiuuous with the postero-lateral margin of the carapace. Postero-lateral margin nearly straight (the anterior part slightly convex, the posterior a little concave) and devoid of a tooth or projection behind the large lateral tooth. Merus of the maxillipeds very obliquely truncated at the distal end, the antero-interual angle rounded, and the inner margin concave (not deeply notched) behind the articulation of the palp. Chelipeds slightly unequal; merus armed with two teeth at the distal end, one on the margin, and one a short distance behind it; the outer surface of the carpus furnished with granulated ridges, the upper one running to a sharp spine at the antero-internal angle; upper surface of the hand furnished with a prominent crest, which is cut into numerous sharp teeth; outer surface with five longitudinal, granulated costæ; fingers more slender than in the preceding species and furnished with more numerous teeth; dactyl armed with a dentate crest on the upper margin. Legs granulated, carpi sulcate above; dactyls strongly compressed, those of the fifth pair widened.

Length of adult specimen ................. $78 \mathrm{~mm}$.

Breadth of adult specimen................. $106 \mathrm{~mm}$.

Alaska, Queen Charlotte Island (Smith), Puget Sound, Oregon, northern to Lower California.

This species is common in and around San Francisco Bay, where it is caught in large numbers for food. It is the common crab of the markets. 


\section{Cancer gracilis Dana.}

Cancer gracilis Daพ̌A, Proc. Acad. Nat. Sci. Phila., Vol. VI, 1852, p. 73; Crust. U. S. Expl. Expd., Vol. I, 1852, p. 153, Pl. VII, fig. 2. Sтiмpson, Proc. Cal. Acad. Sci., Vol. I, 1856, p. 88; Journ. Bost. Soc. Nat. Hist., Vol. VI, 1857, p. 460. Cooper, l. c., 1860, p. 389. LockingтоN, Proc. Cal. Acad. Sci., Vol. VII, 1877, p. 95. Newcombe, Bull. Nat. Hist. Soc. Brit. Col., 1892, p. 23.

Carapace quite strongly convex, finely granulated and not undulated. Front not produced; the three median teeth reach further forward than the outer pair; the central tooth is smaller than the others but projects farther anteriorly. No tooth on the superior orbital margin. Postorbital tooth larger than the ones behind it, which are low, triangular and subequal in size. A small tooth on the nearly straight posterior margin. The pointed extremity of the basal antennal joint does not extend nearly so far forward as in the preceding species. A rounded lobe on the inferior orbital margin just external to the basal antennal joint. Merus of the maxillipeds distally rounded. Merus of the chelipeds with the distal extremity of the upper margin armed with two teeth as in magister; carpus ridged on the outer surface as in magister and having a strong spine at the antero-internal angle, and another spine below it; the upper edge of the hand is acute and may bear a few teeth, but it is often edentulous; the outer surface furnished with granulated costr, which sometimes become quite faint. The fingers resemble those of magister; the upper margin of the dactyl is acute but not dentate; legs long, nearly naked, the dactyls slender, compressed.

$\begin{array}{cccc}\text { Sex. } & \text { Length of Carapace. } & \text { Breadth. } & \text { Proportion. } \\ \text { Male } & 1.51 \mathrm{in} . & 2.30 \mathrm{in} . & 1: 1.52 \\ \text { " } & 1.60 \mathrm{in} . & 2.40 \mathrm{in} . & 1: 1.50 \\ \text { " } & 1.70 \mathrm{in} . & 2.55 \mathrm{in} . & 1: 1.50 \\ \text { Female } & 1.90 \mathrm{in.} & 2.80 \mathrm{in.} & 1: 1.47 \\ \text { " } & 1.45 \mathrm{in} . & 2.13 \mathrm{in} . & 1: 1.47\end{array}$

The males therefore appear to be relatively wider than the females.

Vancouver Island (Newcombe), Puget Sound, Tomales Bay, San Francisco Bay! San Pedro! San Diego!

This is one of the smallest species of the genus Cancer and it is also the rarest of our species. It is more closely allied to magister than to the other forms, but 
may be easily distinguished from that species by the greater convexity and smoothness of the carapace, the character of the antero-lateral teeth and its smaller size.

\section{Genus Trichocarcinus Miers.}

\section{(Trichocera DE HAAN preoccupied.)}

Carapace cancroid in form, the sides rounded; antero-lateral margins not sharply marked off from the postero-lateral; upper surface very uneven. Front with five teeth. Antennules nearly longitudinal. Antennæ quite long, setose on all sides, the first joint elongated and occupying the inner orbital hiatus. Abdomen of the female seven-jointed; in the male fivejointed, the third, fourth and fifth joints fused. Crabs of small size.

\section{Type.-T. gibbosula (DE HaAN.)}

Although this genus was formerly placed among the Corystoid crabs it is in many respects, as Miers has observed, quite closely allied to the genus Cancer. Cancer antennarius shows many characters in common with this genus.

\section{Trichocarcinus Walkeri (new name).}

Trichocarcinus recurvidens WALKER, Trans. Liverpool Biol. Soc., Vol. XII 1898 , p. 271, Pl. XV, figs. 1-1b.

"Carapace $19 \mathrm{~mm}$. long by $23 \mathrm{~mm}$. wide, divided into a number of prominent areolæ of which the surfaces are flattened and granulated; they are separated by deep interspaces. * * * The antero- and postero-lateral margins are ill defined; the former has ten teeth (including the orbital) which are convex on the upper surface, widening distally, and inclined upwards, whence probably the specific name. * * * Eye-stalks short with a bifid calcareous appendage on the upper and inner side. *** Differs from $T$. oregonensis (Dana) in the flatter, more sharply defined areolø, in the distal expansion of the teeth of the antero-lateral margin, and in the different form of the calcareous ocular appendage. Color of areolæ bright red, chelipeds and legs flesh color, fingers black. One male."

\section{Puget Sound.}


The specimen described by Mr. Walker was referred by him to Bate's species only with great hesitation, as Bate's "imperfect description would apply quite as well to T. oregonensis." The determination is made solely on the ground that Bate calls recurvidens a "pretty species"-a term which applies better to Walker's specimen than to the less attractive species of Dana. I do not believe, however, that Walker's identification is correct, as Bate says that recurvidens "may be distinguished by the sharp points of the inner lateral teeth, granulated or minutely baccated along the margin and having the apex recurved." The teeth of the specimen described by Walker, instead of being sharp pointed, are distally widened with a wide, transverse, distal margin. The form that $\mathrm{Mr}$. Walker describes has, therefore, been given a new specific name. Bate's species may be $T$. oregonensis or, as Miers has suggested, the young of Cancer antennarius Stimpson.

\section{Trichocarcinus oregonensis Dana.}

Trichocera oregonensis Dava, Proc. Acad. Nat. Sci. Phila., Vol. VI, 1852, p. 86; Crust. U. S. Expl. Expd., Part I, 1852, p. 299, Pl. XVIII, fig. 5. Stimpson, Journ. Bost. Soc. Nat. Hist., Vol. VI, 1857, p. 464. WhiтEAves, Can. Nat. (2), Vol. VIII, 1878, p. 471.

Trichocarcinus oregonensis Mrers, Proc. Zool. Soc. London, 1879, p. 34; Challenger Reports, Vol. XVII, 1886, p. 110. SмrтH, Rep. Prog. Geol. Sur. Canada, 1878-9, B, p. 207. Newcombe, Bull. Nat. Hist. Soc. Brit. Col., 1893, p. 24. Walker, Trans. Liverpool Biol. Soc., Vol. XII, 1898, p. 271, Pl. XV, fig. 2.

Carapace elliptical, evenly rounded at the sides; areas distinct and elevated, especially in front, and covered with rounded granulations; sulci between the elevations wide, deep and smooth, especially on the anterior portion of the carapace. The front does not project beyond the line of the orbits; the outer pair of teeth (preorbital) are lobe-like, having a broad, granulated edge, and are separated from the inter-antennary portion of the front by a deep, concave notch; the median portion of the front is very short, truncated, and obscurely divided by a slight incision on either side 
of the center into a small median tooth and two larger lateral ones. A tooth between the two fissures in the superior margin of the orbit. Antennules nearly longitudinal, the fosettes extending nearly to the margin of the front. Basal antenual joint not strongly produced at its distal end; second joint broad, flattened, distally expanded and provided with a tuft of long setro at the distal end; third joint subcylindrical and about as long as the preceding; flagellum long and hairy. A small tooth on the inferior margin of the orbit next to the inner fissure. Eye-stalks with a small tooth on the anterior surface. Sides of the carapace armed with ten to thirteen closely set, granulated teeth which extend upon the posterolateral margin; in front of the rounded lateral angles the teeth are strongly upturned and bent forwards; alternate teeth are the more acute; the first sharp tooth the third from the front. Antero-external of the merus of the maxillipeds produced; the inner margin notched behind the articulation of the palp. Chelipeds very stout; merus about as wide as long; carpus gramlated on the outer side, the granules becoming larger above where there may be a few small tubercles; a spine at the antero-internal angle below which there is a tooth; hand thick and high; the short upper edge of the palm bears two rows of small tubercles and on the outer surface there are five delicate, granulated lines, the two lower lines the finest and continued upon the short, thick pollex; both fingers dark colored. Legs hairy; dactyls about as long as the propodi. Sixth abdominal segment in the male nearly square, the last narrowly triangular.

Length of carapace, male....................... $17 \mathrm{~mm}$.

Breadth of carapace, male......................

Mutiny Bay, Alaska! Queen Charlotte Island, Vancouver's Island, British Columbia, Gulf of Georgia, Puget Sound, northern to Lower California! From low tide mark to several fathoms in depth.

\section{Miss Mary Rathbun has recently united Trichocar-} cinus with the genus Cancer and reports two Japanese species, gibbosulus (De Haan) and amphicetus (=Trichocarcinus dentatus Miers), from California. ${ }^{1}$ Oregonensis is closely allied to De Haan's species.

\section{Section XANTHINI Ortmann.}

Carapace rounded or subquadrate. Front wide and generally divided by a median notch. Antennules oblique or transverse.

\footnotetext{
1 See Proc. U. S. Nat. Mus., Vol. XXI, 1898, p. 581.
} 


\section{Genus Cycloxanthops Rath.}

Front horizontal, produced, and divided by a median fissure into two deep, lamellate lobes, which are truncated and separated from the inner orbital angle by a rather deep fissure. Orbits small, with the superior margin marked by two fissures. The postorbital angle is only slightly prominent and is continuous with the antero-lateral margin, which is strongly curved behind. Basal antennal joint short, but joined at its internal angle to the front; the flagellum is inserted in the inner orbital hiatus. Merus of the maxillipeds subquadrate, the anterior margin not oblique. The abdomen in the male is composed of five free joints.

Type.-C. sexdecimdentatus (EDw. \& LuCAS).

The genus Cycloxanthus was established by MilneEdwards ${ }^{1}$ to receive some species of fossil crabs. Finding subsequently that this species was a synonym of Zanthopsis M'Coy, Edwards applied the name Cycloxanthus, which he considered as having thus become "disponible," to an entirely different genus of which he made sexdecimdentatus the typical species." According to the rule, "Once a synonym always a synonym," the name Cycloxanthus is no longer available for use.

\section{Cycloxanthops novem-dentatus (Lock.)

$$
p l . I, f .2 \text {. }
$$

Xanthodes? novem-dentatus Lockington, Proc. Cal. Acad. Sci., Vol. VII, 1877 , p. 32.

Xantho novem-dentatus Lockington, Ibid., 1877, p. 99. Kingsley, Proc.

Bost. Soc. Nat. Hist., Vol. XX, 1879, p. 153.

Cycloxanthus californiensis Rathbun M., Proc. U. S. Nat. Mus., Vol. XVI, 1893, p. 237.

Carapace wide, flattened, and more or less punctate behind; convex, granular and rugose in front. Median region divided into three welldefined regions by distinct sulci; branchial regions divided by a transverse sulcus arising from the lateral angles. Front horizontal, produced, edentate, with the anterior margin nearly transverse, but a little advanced in the center, and divided by a deep, closed, median notch which may become

1 dans d'Archiac, Hist. des progr. de la géologie, T. III, p. 304, $\mathrm{K}$.

2 Ann. Sci. Nat. (4), T. XX, 1863, pp. 278 and 307. 
obliterated above by the fusion of the two sides; the anterior margin of the lobes may be straight, or, more often, slightly concave; seen from in front they are gently arched upward, or in some cases very strongly so. Antero-lateral margin armed with eight or nine small subacute teeth whose bases are generally narrower than the spaces between them; postorbital tooth small; next tooth also small, depressed and often lobate, and separated from the postorbital by a considerably greater interval than from the succeeding tooth; at the rounded sides of the carapace the teeth become larger, more acute, and more closely set. There is a tendency to alternation in the size of the teeth; the fourth tooth, counting the postorbital, is larger than the filth, and the sixth and eighth are larger than the seventh; ninth tooth small and situated behind the lateral angle; a small tenth tooth often occurs closely behind the ninth. On the outer margin of the orbit above the postorbital tooth there are two small, blunt teeth separated by a narrow fissure; preorbital tooth distinct; suborbital lobe acute. Basal joint of the antennules with a pronounced ridge on the outer surface with a groove on either side. Merus of the maxillipeds obliquely truncated at the anterior end. Merus of the chelipeds hairy above; carpus rugose, and furnished with two blunt teeth at the antero-internal angle; hand rugose above, and rather long, with the upper and lower margins nearly parallel; fingers long, sulcate, not gaping, and colored brown, with light colored tips. Legs with the margins hairy; dactyls longer than the propodi and terminating in nearly straight, corneous claws. Abdomen in the male narrow, the second joint a little over a half longer than wide, penultimate joint longer than wide; last joint about as long as broad, with the distal end rounded. In the abdomen of the female the second joint is longer than the third or fourth, which are subequal and shorter than the fifth; sixth joint the longest, nearly equaling the third and fourth combined; last joint broader than long, and in adult specimens broadly rounded at the tip.

The following measurements are from a series of specimens from San Diego, California:-

Length of Carapace. Width of Carapace.

$\begin{array}{cllll}\text { Male. } & 25.75 \mathrm{~mm} . & 38.75 \mathrm{~mm} . \\ \text { “ } & 25 & \mathrm{~mm} . & 37.5 & \mathrm{~mm} . \\ \text { " } & 24 & \mathrm{~mm} . & 35.25 \mathrm{~mm} . \\ \text { " } & 23 & \mathrm{~mm} . & 35 & \mathrm{~mm} . \\ \text { " } & 22 & \mathrm{~mm} . & 32 & \mathrm{~mm} . \\ \text { " } & 20 & \mathrm{~mm} . & 30 & \mathrm{~mm} . \\ \text { " } & 18 & \mathrm{~mm} . & 26 & \mathrm{~mm} . \\ \text { " } & 14.75 \mathrm{~mm} . & 21 & \mathrm{~mm} .\end{array}$




$\begin{array}{ccccc} & \text { Length of Carapace. } & \text { Width of Carapace } \\ \text { Female. } & 26 \mathrm{~mm} . & 40 & \mathrm{~mm} . \\ \text { “ } & 21.75 \mathrm{~mm} . & 32 & \mathrm{~mm} . \\ \text { “ } & 15 & \mathrm{~mm} . & 21.5 \mathrm{~mm} . \\ \text { ". } & 11 \mathrm{~mm} . & 16 & \mathrm{~mm} .\end{array}$

One large specimen from southern California (precise locality unknown) measured $36.25 \mathrm{~mm}$. by 56.75 $\mathrm{mm}$.

San Pedro! San Diego! southern California! Catalina Harbor (Rathbun, M.), Guadalupe Island, Lower California (Rathbun, M.), San Clemente Island!

This is a very common species on the coast of southern California. I have not seen Lockington's type, which could not be found in the Academy, but there were other specimens in Lockington's collection which bore the name Xantho vittata St. written above the earlier name $X$ antho novem-dentatus which had been partly scratched out. I have seen the types of Cycloxanthus californienis and compared them with specimens I had identified as novem-dentatus by a comparison with the specimens in Lockington's collection. There is, I believe, no doubt that the two species are identical. This species is closely allied to vittatus St., but I think we must accept Miss Rathbun's conclusion, that it is distinct, although it was considered a synonym of the latter species by Milne-Edwards and subsequently by Lockington himself. At the National Museum in Washington I had the opportunity of comparing specimens of vittatus from the western coast of Mexico with several specimens of this species. The former species differs in its longer and sharper lateral teeth, its broader hands, and its narrower abdomen. 


\section{Cycloxanthops rugosa, sp. nov.}

Carapace very uneven, granulated, and thickly covered with small, circular pits. Postorbital tooth small; antero-lateral teeth irregular. Anterior portion of the subhepatic region prominently granulated and pitted and not sharply separated from the strongly sloping anterior portion of the hepatic area. Front shorter and more depressed than in novemdentatus. External maxillipeds much as in the preceding species; merus pitted and granulated. Carpus of the chelipeds strongly reticulated above; a prominent tooth at the antero-internal angle, below which is a smaller tooth. Hands narrow, strongly reticulated above and on the upper portion of the outer surface, the inner margin of the upper side furnished with several irregular tubercles. Ambulatory legs much as in novemdentatus but less hairy.

San Diego, California. Collected by A. U. Crawford.

Described from a specimen in the museum of the University of California. Easily distinguished by the conspicuous pits and prominent granulations of the carapace.

\section{Genus Lophoxanthus A. Milne-Edwards.}

Carapace broader than long, flattened, the anterior portion of the anterolateral margins straight, nearly devoid of teeth, and meeting the dentate posterior portion at an angle. Front short and divided by a median fissure into two broad, truncated lobes. Orbits nearly circular and marked with fissures which are closed or even obsolete. Basal antennal joint short and in contact with the infero-lateral process of the front, but not entering the inner orbital hiatus. Maxillipeds nearly quadrate, the merus distally truncated, the antero-external angle not produced. Ambulatory legs compressed and carinated or crested above. Abdomen in the male five-jointed.

\section{Type.-L. lamellipes (STIMPson.)}

This genus is doubtfully distinct from Lophozozymus, being distinguished chiefly by its more transverse carapace and the absence of conspicuous teeth on the anterior portion of the antero-lateral margins. The three species of this genus here described are closely allied. In all these the areolation of the carapace is distinct, the postorbital tooth minute, the anterior half of the antero-lateral margin straight and furnished with a single low, obscure tooth, the posterior half nearly longitudinal and furnished with three, prominent, subequal teeth, the epistome with a ridge extending upon it from the sides, the inferior inner orbital tooth 
pointed, and the tooth external to the latter obtuse and separated from the postorbital by a fissure, the upper margin of the orbit furnished with two fissures, the merus of the maxillipeds rectangular, notched behind the articulation of the palp, and crossed by an oblique ridge, the chelipeds stout, the merus trigonous and dentate above near the distal end, the carpus rounded and furnished with a tooth at the inner angle, the hands with a lobe pointing inward at the base of the upper side of the palm, the fingers irregularly dentate within but with the outer margins rounded; the ambulatory legs furnished above with lobulated crests on the carpi and propodi, the dactyls slender and villous, the second segment of the abdomen narrowed distaliy, the third segment wider at the base than the distal end of the second and touching the coxæ of the fifth pair of legs, the last two segments of subequal width, the terminal joint rounded.

\section{Lophoxanthus bellus (Stimpson).}

Xantho bella Stimpson, Ann. N. Y. Lyc. Nat. Hist., Vol. VII, 1860, p. 204, Pl. III, fig. 2. BATE, in Lord's Nat. in Vancouver's Island, Vol. II, 1866, p. 270. Newcombe, Bull. Nat. Hist. Soc. Brit. Col., 1893, p. 24. Xanthodes Hemphillii Lockington, Proc. Cal. Acad. Sci., Vol. VII, 1877, p. 31.

Xanthodes Hemphilliana Lockington, 1. c., 1877, p. 100.

Lophoxanthus bellus A. Milne-Edwards, Crust. Miss. Sci. au Mex., Pt. V, p. $256, \mathrm{Pl}$. XIVI, fig. 4.

Lophozozymus (Lophoxanthus) bellus Miars, Challenger Reports, Vol. XVII, 1886, p. 115.

Lophopanopeus bellus Rathbun M., Bull. Lab. Nat. Hist., Univ. Iowa, 1898, p. 272.

Carapace flattened behind, convex in front, and transversely nearly plane; surface distinctly areolated, becoming roughened toward the anterolateral margins. Front generally sinuate, and divided by a median fissure, the outer angles produced into small rounded lobes or teeth, which are separated from the adjacent supraorbitals by a fissure. Postorbital tooth small. The anterior half of the antero-lateral margin is nearly straight, meeting the posterior half at an angle, and furnished with a single low, inconspicuous tooth which is sometimes absent; posterior half furnished with three prominent, subequal; horizontally flattened teeth, the anterior one the least acute. Postero-lateral margins nearly straight, rapidly converging. The infero-internal angle of the orbit is produced into a prominent pointed tooth; a broad lobe-like tooth at the infero-external angle of the orbit separated from the postorbital above by a fissure. Merus of the maxillipeds subrectangular, the surface with two depressions separated by an oblique elevation. Chelipeds stout, the upper margin of the merus furnished with a few irregular teeth; surface of the carpus more or less roughened, the antero-internal angle furnished with a tooth which is 
typically double, the lower cusp obscure; hands rounded above and furnished with a lobe projecting inward at the intero-proximal portion of the upper side; fingers black or dark brown. Abdomen in the male five-jointed, the last segment rounded and slightly wider than the preceding one, which is somewhat wider than long. Merus of the ambulatory legs acute abore; carpus with a bilobed crest; crest of the propodus often with a lobe at the base; dactyls villous. Color purplish, the legs crossed with lightcolored bar's.

Found among rocks at low tide from British Columbia to Monterey. Vancouver Island (Bate, Newcombe), Puget Sound (Stimpson)! northern California! Monterey (Stimpson, Lockington)!

\section{Locality.}

Puget Sound; male

Puget Sound; female

Monterey; male, type of

Hemphillii Lock.
Length.

$19 \mathrm{~mm}$.

$15.75 \mathrm{~mm}$.

$18.75 \mathrm{~mm}$.
Width.

$26.5 \mathrm{~mm}$.

$22.5 \mathrm{~m} m$.

$28 \mathrm{~mm}$.

Two specimens whose measurements are given by Stimpson were .54 by .80 in. and .56 by .89 in. "Northern specimens," says Stimpson, "are more transverse, rougher, more pubescent, and more sober in coloration than those found in warmer latitudes." Possibly specimens of leucomanus or frontalis were confused with this species. I have seen Lockington's type of Hemphillii (No. 35) which is preserved in the collection of the California Academy of Sciences. It is a typical bellus and as strongly transverse and as rough as the specimens I have seen from farther north. The specimen from Lower California which is figured as $L$. bellus by A. Milne-Edwards (l. c.) probably belongs to a different species.

\section{Lophoxanthus leucomanus (Lock.)}

Xanthodes leucomanus LockiNGTó, Proc. Cal. Acad. Sci., Vol. VII, 1877, pp. 32 and 100.

Lophoxanthus bellus A. Milne-Edwards, Crust. in Miss. Sci. au Mex., Pt. V., p. 256 (in part).

Lophopanopeus leucomanus Rathвox MI., Bull. Lab. Nat. Hist. Univ. Iowa, 1898, p. 272. 
Closely allied to bellus, but having the anterior portion of the anterolateral margin not so nearly transverse, the surface of the carapace more eroded, the lateral teeth narrower and more nearly conical, the ambulatory legs somewhat more slender and more prominently crested. The areolation of the carapace is plain; the front is produced more than in bellus, and divided by a median notch, the lobes sinuate with the outer angles produced as in the preceding species. Orbital fissures and teeth as in bellus; lateral teeth of the carapace subconical, prominent and subequal, the anterior one least acute. Subhepatic regions eroded, especially near the orbits. Chelipeds unequal; merus irregularly dentate on the upper margin; carpus and upper surface of the hand generally eroded or furnished with a network of raised lines; hand with a lobe at the base as in bellus; fingers light to dark brown. Merus of the ambulatory legs with an acute upper margin which usually ends in a tooth near, but not at the distal end; carpus with a bilobed crest above; crest of the propodus with a lobe near the base. Dactyls rather slender.

Locality.

Monterey, male.

Santa Catalina Island, male.

Southern California, male.

" " female.

West America, male.

" " female.

" " "

La Paz, Lower California, male.

" " " " " "

" " " " $"$ female.
Length.

$13.5 \mathrm{~mm}$.

$12.5 \mathrm{~mm}$.

$8.5 \mathrm{~mm}$.

$11.25 \mathrm{~mm}$.

$13.5 \mathrm{~mm}$.

$10 \mathrm{~mm}$.

$10 \mathrm{~mm}$.

$7.75 \mathrm{~mm}$.

$6.5 \mathrm{mn}$.

$7 \mathrm{~mm}$.
Width.

$18.5 \mathrm{~mm}$.

$17.75 \mathrm{~mm}$.

$11.25 \mathrm{~mm}$.

$14.75 \mathrm{~mm}$.

$18 \mathrm{~mm}$.

$13 \mathrm{~mm}$.

$13 \mathrm{~mm}$.

$10 \mathrm{~mm}$.

$8.5 \mathrm{~mm}$.

$9 \mathrm{~mm}$.

Monterey (Lockington)! Santa Catalina Island! San Diego and Santa Rosa Island (Lockington), La Paz, Lower California (Lockington)! "Southern California," two specimens (No. 17286 U. S. National Museum)! San Clemente Island! San Diego!

This species varies considerably as regards the roughness of the carapace and legs. In some cases the anterior part of the carapace and the upper side of the carpus and manus of the chelipeds are very much eroded, but occasionally they are nearly smooth; the tubercle on the middle of the surface of the maxillipeds is often 
prominent, but in some specimens it is quite inconspicuous. The crests on the ambulatory legs are also quite variable, and the tooth at the end of the sharp upper edge of the merus may be absent. These differences are probably due, in great measure, to age.

The forms from near Japan which Miers identified with this species under the name Lophozozymus (Lophoxanthus) bellus St. var. leucomanus Lock. belong, I believe, to a distinct species. The lateral teeth in Miers' form are quite different from leucomanus; the hands, as shown in Miers' figure, lack the lobe at the base of the palm; "the mobile finger is longitudinally carinated and sulcated above," while in leucomanus it is rounded and perfectly smooth; the pits on the upper side of the hand are arranged in longitudinal series, but in leucomanus this arrangement is not shown. ${ }^{1}$

The types of leucomanus are probably no longer preserved. I have specimens from localities from which this species was reported by Lockington, and I have seen Lockington's specimens from La Paz, Lower California. ${ }^{2}$ These specimens are small and strongly eroded, but present no well-marked differences from the northern forms.

None of the specimens of leucomanus I have seen attain nearly the size reached by bellus.

1 See Challenger Reps., Vol. XVII, p. 115, P1. XI, fig. 1.

2 See Proc. Cal. Acad. Sci., Vol. VII, 1877, p. 100. 


\section{Lophoxanthus frontalis (Rathbun).} Pl. I. f. $5+6$.

Lophozozymus (Lophoxanthus) frontalis Rathbun M., Proc. U. S. Nat. Mus., Vol. XVI, 1893, p. 236.

Lophopanopeus frontalis RATHBUn M., Bull. Lab. Nat. Hist., Univ. Iowa, 1898, p. 272.

Closely allied to the two preceding species, especially to leucomanus. The shape of the carapace is nearly the same as in the preceding species, but the upper surface is smoother, not eroded, the lateral teeth more flattened horizontally and slightly upturned; the areolation is plain; the subhepatic regions are granulated but not eroded. Front considerably produced, sinuate, the median notch deep. Orbits and orbital teeth as in leucomanus. Maxillipeds granulated, the merus shaped as in the two preceding species, and crossed by an oblique elevation. Chelipeds unequal; merus with a few teeth on the upper margin; carpus rugose or nearly smooth, with a tooth at the.inner angle and a tubercle at the base on the upper side; hands large, with a lobe pointing inward at the base of the upper side of the palm; fingers brown, the color extending far back on the hand. Legs rather slender, more or less harry, the upper edge of the merus acute but having no well-marked tooth near the end; crests of the carpus and propodus as in leucomanus but less prominent; dactyls slender.

Length of carapace $15 \mathrm{~mm}$.; width $20 \mathrm{~mm}$.; length of larger hand $16 \mathrm{~mm}$.

Described from a specimen from San Diego sent by Miss Rathbun (No. 19823, U. S. National Museum).

San Diego (Rathbun)! Monterey (Rathbun).

This species may readily be distinguished from bellus by its different shape; the portion of the carapace lying in front of a line connecting the tips of the first lateral teeth is about one-fourth the length of the whole carapace in bellus, and about one-third of this length in leucomanus and frontalis. The color of the fingers extends far back upon the hands in this species, while in both the preceding it does not extend further back than the base of the fingers. The front is much more produced than in bellus. The hands and carpal joints of the chelipeds are, like the carapace, much less eroded than in leucomanus, and the merus of the maxillipeds has the oblique ridge low and flattened and not raised into a tubercle in the center. 


\title{
Genus Xanthias Rathbun.
}

\author{
(Genus Xanthodes Dasa, preoc.)
}

Carapace transverse, distinctly areolated, more narrow and convex than in the genus Xantho, to which it is very closely allied. Antero-lateral margin not thin-edged or cristiform; teeth tuberculiform or even spinous. Posterior portion of the carapace depressed. Antennules transversely or obliquely plicated. Basal antennal joint short, and barely reaching the slender, narrow, infero-lateral process of the front, and not produced within the hiatus of the orbit; flagellum not excluded from the orbit. Chelipeds stout, the tips of the fingers acute (not excavated within). Ambulatory legs compressed or subcylindrical and devoid of a crest on the upper margin. Abdomen of the male five-jointed.

\section{Xanthias Taylori( $S t$.}

Xanthodes Taylori Stmpsox, Ann. N. Y. Lyc. Nat. Hist., Vol. VII, 1859, p. 208, Pl. III, fig. 3. Streets and Kingsiey, Bull. Essex Inst., Vol. IX, 1878, p. 105. A. Milne-Edwards, Crust. in Miss. Sci. au Mex., Pt. V, p. 260, Pl. XLV, fig. 3.

Xantho spini-tuberculatus Lockington, Proc. Cal. Acad. Sci., Vol. VII, 1877, pp. 31 and 99.

Carapace flat behind; in front quite strongiy convex longitudinally but transversely nearly plane. Areolets distinct and embossed anteriorly; antero-lateral regions strongly lobulated with a prominent, smooth, rounded lobule above each marginal tooth. The lobes of the front are separated by a wide, roundea notch and furnished with a rounded tooth at the inner and outer angles, between which are several small, baccate protuberances. Closely behind and parallel with the anterior margin of the front is a baccated ridge interrupted in the middle by the prominent longitudinal groove which extends backwards from the median notch. Behind this ridge is another elevation not so distinctly baccated, which is separated by a transverse sulcus from the elevated anterior margins of a pair of lobules lying behind it. Median region divided into three distinct areas. Inner orbital angle prominent and separated by a deep notch from the outer angle of the front. Upper orbital margin with a rounded tooth bounded by a pair of sulci. Postorbital tooth small and continuous externally with a rounded protuberance; the latter is separated by a smooth sulcus from a pair of smooth, rounded prominences, one of which is situated directly above the other. The three posterior teeth on the anterolateral margin prominent, the last two acute and curved forwards, the first obtuse and generally more or less bifid. A small tooth usually present behind the one at the antero-lateral angle. A tooth below the infero. 
orbital fissure, and a prominent, subacute tooth at the infero-interual angle. Ocular peduncle with a few baccations in front. Antennules transversely plicated, the basal joint with a granulated or baccated ridge. Basal antennal joint short but touching the outer angle of the front. Merus of the maxillipeds subrectangu lar, transversely truncated in front, with the outer angle rounded and slightly produced. Chelipeds stout, more or less unequal; merus trigonal, with the distal portion of the upper margin armed with a few spine teeth; carpus thickly covered with prominent, rounded, smooth, glossy, rose-colored tubercles; hand oblong, with the palm longer than wide, the upper and outer surface covered with rose-colored tubercles like those on the carpus, arran ged in seven or eight longitudinal rows; fingers stout and colored black, the color not extending back upon the hand. Legs compressed, thickly covered with stiff setæ and strongly spinous, especially on the merus and propodus; dactyls about as long as the propodi. Abdomen of the male five-jointed, the penultimate joint about as long as wide; last joint broadly rounded.

Length of carapace $13 \mathrm{~mm}$; breadth $19.5 \mathrm{~mm}$.

Monterey (Stimpson)! Santa Rosa! San Pedro! San Diego! Santa Catalina Island! Magdalena Bay and San José Island (Lockington).

"This species," says Lockington, "appears to be of common occurrence from Monterey southward to Magdalena, but to disappear, or at least to become rare, in localities further south."

\section{Xanthias latimanus (Lock.)}

Xanthodes latimanus Lockington, Proc. Cal. Acad. Sci., Vol.VII, 1877, p. 31. Xantho latimanus Lockington, 1. c., p. 101.

Lockington's description of this species is as follows: "Front sinuate, the inner angle of the orbit raised into a point; carapax but slightly transverse; teeth N. T. S. prominent and pointed, D and $\mathrm{E}$ almost obsolete; areolation of medial and antero-lateral regions distinct, the former having the parts $2 \mathrm{M}$ and $3 \mathrm{M}$ entirely outlined. Hands subequal, the right somewhat the larger; movable fingers very long and curved abruptly downward; margin of manus continuous with the broad base of the fixed finger so as to form a sinuous sloping line; hinder feet compressed. This species may readily be identified by the delicate marbling of the carapace and chelipeds, and the downward bend of the movable fingers. Abdomen. of male five-jointed.

"A single male specimen from San Diego.

"Length 0.73 ; breadth 0.88 [inch]." 
I have never seen this species and the description is not sufficiently complete to enable one to determine whether or not it belongs in the genus in which Lockington placed it. Professor A. Milne-Edwards considers it identical with Stimpson's Micropanope latimana. Milne-Edwards does not mention having seen latimana, and as he simply transcribes Stimpson's description it is quite certain that he bases his identification solely upon the descriptions of the two authors. The identification is not improbably correct, but considering the brevity of both the descriptions, it is somewhat unsafe to unite the two species, especially since the characters mentioned by Stimpson are mainly those of which Lockington says nothing.

\section{Genus Pilumnus Leach.}

Carapace couvex, little broader than long, and hairy above. Anterolateral margins regularly arcuated, shorter than the postero-lateral, and armed with short spines. Front narrow, emarginate. Endostome longitudinally carinated. Basal antennal joint short, barely reaching the infero-lateral frontal process and lying under the orbit. Ambulatory legs compressed, not carinated, and armed with spinules; dactyls slender, nearly straight. Abdomen of the male seven-jointed.

\section{Pilumnus spino-hirsutus (Lock.)}

Acanthus spino-hirsutus Lockington, Proc. Cal. Acad. Sci., Vol. VII, 1877, pp. 32 and 102.

Pilumnus spino-hirsutus Streets and Kingshey, Bull. Essex Inst., Vol. IX, 1877, p. 107. Kirgsley, Proc. Bost. Soc. Nat. Hist., Vol. XX, 1879, p. 154. A. Milve-Edwards, Crust. in Miss. Sci. au Mex., Pt. V, p. 278. Miers, Challenger Reports, Vol. XVII, 1886, p. 147.

Carapace strongly convex, nearly smooth, but covered with stiff setæ. Median frontal lobes truncated, separated by a prominent notch, and armed each with four or five spines; lateral lobes of the front small, separated from the median lobes by a deep notch and ending in a spine. Orbits with the upper, lower aud outer margins armed with strong spines of unequal size, the two spines at the intero-inferior angle large and situated on a kind of lobe. Besides the postorbital the antero-lateral margin is armed with three strong spines, and there is a small spine below the margin in front of the first of these. The basal antennal joint barely 
reaches the infero-lateral frontal process. Endostome plainly carinated. Pterygostomian regions more or less granulated. Chelipeds unequal, setose; merus scarcely as long as high, the margins finely denticulated; a spine at the supero-distal angle separated from a similar spine behind by a deep notch; outer surface of the carpus thickly covered with spines; upper and outer surface of the hand covered with several series of spines; lower margin finely denticulated; fingers dark colored. Legs setose; carpus and propodus armed above with spines; merus with a spine at the supero-distal angle; dactyls hairy, nearly straight, and subequal to the propodi. Terminal segment of the abdomen in the male triangular.

San Diego, California (Lockington's type)! Mulege Bay, Gulf of California!

\section{Appendix to the XANTHINI Ortmann.}

\section{Genus Telemessus White.}

Carapace depressed, subpentagonal, broader than long and covered with setæ. Front wide, the median portion cut into four teeth and separated by a sinus from the lateral portions which form the preorbital teeth. The antero-lateral and postero-lateral margins are dentate and meet each other at an angle. Orbits large; postorbital tooth prominent. Antennules folded longitudinally or nearly so in wide fossettes. Epistome with a triangular point extending forward between the antennules. Basal antennal joint broad, forming a part of the outer wall of the antennulary fossettes and produced on the outer side into a lobe which occupies the inner hiatus of the orbit; flagellum quite long. Maxillipeds produced a little beyond the anterior margin of the buccal area; the merus has a mole or less triangular apex and bears the palp on the inner margin just behind the tip. Chelipeds setose and scabrous or spinous and rather short in both sexes; merus trigonous; hands compressed and furnished with spinous or tuberculated ridges on the outer surface. Legs quite long, compressed, scabrous or spinose; dactyls long, compressed, acute. Abdomen of the female seven-jointed, the sides of the sixth joint concave, leaving the genital openings exposed. Abdomen of the male widest at the third segment and having the third, fourth and fifth joints fused.

Type.-T'. cheiragonus (TILesios).

Unless Latreille's bare mention in a list of genera of the name Cheiragone ${ }^{1}$ without referring to it any species

1 Familles nat. a Paris, 1825, p. 270. 
constitutes the genus Cheiragonus (or Cheiragone), Telemessus has priority. According to the A. O. U. code, Cheiragone must be considered a "nomen nudum."

\section{Telemessus cheiragonus (Tilesius).}

Cancer cheiragonus Tilesios, Mem. Acad. St. Petersbonrg, T. V, 1815, p. $347, \mathrm{Pl}$. VII, fig. 1.

Telémessus serratus White, Ann. Nat. Hist., Vol. XVII, 1846, p. 497; Voyage of Samarang, Crustacea, 1848, p. 14. Dasa, Crust. U. S. Expl. Expd., Part I, 155̃2, p. 303, Pl. XVIII, fig. 8. SuIth, Rep. Prog. Geol. Sur. Canada, 1878-9, B, p. 208.

Platycorystes ambiguus BraxdT, Bull. Phys-math. Acad. St. Petersbourg, T. VII, 184S, p. 179.

Platycorystes cheiragonus BRANDT, Middendorff's Siberische Reise, Bd. II, Th. 1, 1S51, p. 85.

Cheiragonus hippocarcinoides BRANDT, Middendorff's Siberische Reise, Bd. II, Th. 1, 1S51, p. 147. Strmpsoy, Journ. Bost. Soc. Nat. Hist., Vol. VI, 1857 , p. 465 .

Telemessus serratus and T. cheiragonus Miers, Proc. Zool. Soc. London, 1879, p. 36 .

Telemessus cheiragonus Benedict, Proc. U. S. Nat. Mus., Vol. XV, 1892, p. 224, Pls. XXXV and XXXVI, figs. 2, 3 and 4. Newconbe, Bull. Nat. Hist. Soc. Brit. Col., 1893, p. 24. WALkeR, Trans. Liverpool Biol. Soc., Vol. XII, 189S, p. 373.

Cheiragonus cheiragonus OrtManx, Zool. Jahrb. Abth. f. Syst., Bd. VII, 1894, p. 420.

Carapace depressed, areolated, furnished with granules and thickly corered peculiar clavate setæ. The teeth of the median lobe of the front are triangular, subequal, and extend forward to about the same distance. The preorbital teeth are large and acute and the rounded sinus between them and the median frontal lobe is armed with secondary teeth. Postorbital tooth acute. The margins of the orbit are denticulated and the upper margin is furnished with two small fissures; lower margin entire but deeply concave. Lobe of the basal antennal joint triangular. Merus of the chelipeds spiny; two rows of spines on the upper edge of the hand (the onter row may be reduced to tubercles) and below these four rows of spines or tubercles on the outer surface. Legs furnished with transverse, setose, granulated or, in some cases, spinous lines; dactyls strongly grooved, longer than the propodi. The abdomen of the male is abruptly contracted behind the third segment, a small part of the posterior margin of which projects nearly transversely. The antero-lateral margin of the 
carapace is furnished with four prominent triangular teeth including the postorbital and the one at the lateral angle; the posterior margins of these teeth are armed with several denticles and the three anterior teeth have each two denticles on the anterior margin; the fourth tooth has three nearly equally spaced denticles on the inner side of its anterior margin and a fourth at a longer interval from the others near the tip. Posterolateral margin with two teeth. Body and appendages strongly setose.

Length of carapace, $50 \mathrm{~mm}$; breadth, $64 \mathrm{~mm}$.

Northeastern Siberia, Aleutian Islands, Behring Sea, Sitka, Vancouver's Island, Puget Sound, upper California.

There is a specimen in the museum of the University of California labelled Gulf of California, but possibly this is wrong, as this species appears to be a northern one. This species may be distinguished from $T$. acutidens by its broader carapace, its larger and broader lateral teeth and by the median teeth of the front. For a fuller list of localities and other facts concerning this peculiar species see Benedict l. c., pp. 224-227.

\section{Section PORTUNINEA Ortmann.}

Carapace more or less rounded, with the antero-lateral margin sharply marked off from the postero-lateral. The last pair of thoracic legs fitted for swimming. Verges of the male in the $\cos \infty$.

\section{Genus Portunus Fabr.}

Carapace usually transverse, depressed, and marked with granulated lines. Front short and cut into five to eight teeth. Antero-lateral margins arcuated and armed with nine teeth, all but the last (the largest) being of subequal size. Flagellum occupying the inner orbital hiatus. Merus of the chelipeds armed with spines on the inner margin; hand elongated, prismatic and costate.

Type.-P. pelagicus (Lins.). 


\section{Portunus Xantusii (St.)}

Achelous Xantusii Strmpsox, Ann. N. Y. Lyc. Nat. Hist., Vol. VII, 1860, p. 222.

Neptunus asper A. Mrlne-Edwards, Archiv. du Mus. Hist. Nat. Paris, T. X, 1860, p. 325, Pl. XXX, fig. 3.

Neptunus Xantusii A. MrLve-EdwaRds, 1. c., 1860, p. 429; Crust. in Miss. Sci. au Mex., Pt. V, p. 213, Pl. XXXVIII, fig. 1, and PI. XXXIX, fig. 3.

Amphitrite paucispinis Lockirgtox, Proc. Cal. Acad. Sci., Vol. VII, 1877, p. 107.

Portunus Xantusii Rathbov M., Proc. U. S. Nat. Mus., Vol. XXI, 1898, p. 593.

Carapace markedly transrerse, the upper surface pubescent. Gastric area with a median granulated line and a transverse line, near the middle, which is slightly concave in front; the posterior portion crossed by a short transverse line; a granulated line beginning near the posterior part of the gastric area, at first arching forwards, and then curving backwards near the side of the carapace and extending upon the large lateral spine; two short, oblique, parallel lines on the branchial areas; on the cardiac region there are two short transverse lines situated end to end, their inner extremities curving backwards and meeting to form a longitudinal, median line which is often obscure. Front short and not projecting beyond a line drawn across the tips of the acute triangular projections of the inferior margin of the orbit, the four frontal teeth are equally prominent, the two middle ones slightly narrower than the outer pair and separated from the latter by a slightly wider interval than they are separated from each other. The tooth at the inner angle of the orbit is double pointed. The postorbital tooth is larger than the one behind it and extends nearly as far forward as the teeth of the front. The antero-lateral teeth are sharp and curved forward and show a tendency to alternate in size; the lateral spine is about three times as long as the tooth in front. Upper margin of the orbit with two fissures and a small tooth on the inner side of the outer fissure. A single fissure in the lower orbital margin external to which is a small cusp upon the under side of the postorbital tooth. Chelipeds pubescent, merus armed in front with four to seren spines; posterior margin scabrous but not spiny, with the exception of a small spine at the distal end; carpus with several granulated ridges on the outer surface; a strong spine at the distal end of the upper margin and a smaller spine on the lower side at the distal end of the lowest granulated ridge; hand furnished with a spine at the external hinge joint; the granulated ridge on the upper margin terminates in a spine a little behind the distal end of the palm; four granulated ridges on the outer surface of the hand not counting the upper one; fingers strongly ridged, teeth dark colored; first 
three pairs of legs slender; merus unarmed. In the male the first and second abdominal segments are free, the third, fourth and fifth coalesced; second and third joints transversely ridged and produced laterally into two acute processes which project beyond the margins of the other segments; sides of the fourth segment strongly convex; last segment narrow and shorter than the preceding one. In the female, the second and third joints are much like those of the male; fourth and flfth transversely ridged, fifth and sixth of subequal length; last joint very small and triangular.

Length of carapace, male......................

Breadth of carapace, male, between tips of lateral spines...53 $\mathrm{mm}$.

Length of cheliped, male.......................

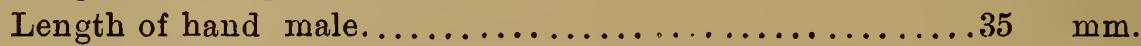

Another specimen measured $26 \mathrm{~mm}$. by $52 \mathrm{~mm}$.

South America (Milne-Edwards), West Mexico, Panama (Milne-Edwards), Cape St. Lucas (Stimpson), San Diego! Santa Catalina Island! San Pedro!

The specimens of Amphitrite paucispinis which were sent by Lockington to Streets and Kingsley were, I believe, wrongly identified with Stimpson's Achelous panamensis, instead of with $A$. Xantusii Stimpson, to. which species I feel sure they belong ${ }^{1}$. Judging from Stimpson's descriptions, Xantusii and panamensis are closely allied, the latter species being distinguished by the presence of a spine on the merus of the ambulatory legs. Streets and Kingsley state that Lockington's specimens agreed very well with Stimpson's description of panamensis, except that the spine on the merus of the ambulatory legs was absent. I have examined some of Lockington's. specimens of Amphitrite paucispinis, which are in the possession of the California Academy of Sciences, and they agree perfectly with Stimpson's description of Achelous Xantusii, and A. Milne-Edwards' excellent figures of that species in the "Mission Scientifique au

\footnotetext{
${ }^{1}$ See Bull. Essex Inst., Vol. IX, p. 107.
} 
Mexique." Panamensis apparently does not range so far north as Lower California, while Xantusii is common from southern California southward.

\section{Genus Callinectes Stimpson.}

Closely allied to Portunus. Carapace broad; front low. Merus of the external maxillipeds prominent and curved outward at the antero-external augle. Abdomen in the male narrow and $\perp$-shaped.

\section{Callinectes bellicosus (Stimpson).}

Lupa bellicosa (Sloat MS.) Strupson, Ann. N. Y. Lyc. Nat. Hist., Vol. VII, 1859, p. 57.

Callinectes bellicosus Ordway, Proc. Bost. Soc. Nat. Hist., Vol. VII, 1863, p. 577. Rathbux M., Proc. U. S. Nat. Mus., Vol. XVIII, 1895, p. 365, Pls. XXII, XXIV. fig. 10; XXV, fig. 8; XXVI, fig. 8; and Vol. XXI, 1898, p. 596.

Lupa bellicosa? Lockington, Proc. Cal. Acad. Sci., Vol. VII, 1877, p. 105. Callinectes bellicosus A. MrLne-Edwards, Miss. Sci. au Mex., Pt. V, 1879, p. 227, (var. of $C$. diacanthus).

Carapace broad, convex, minutely granulated. Front with two distant spines, the margin between them sinuous. Preorbital teeth not so advanced as the lateral teeth of the front; postorbital tooth long, exceeding the preorbitals; subfrontal spine exceeding the lateral frontal teeth; a large tooth below the preorbital, which extends further forward than the others. Inner superior orbital fissure open. Teeth behind the postorbital broadly triangular, acute, with concave sides; last tooth about twice the length of the preceding one, its upper edge continued as a fine ridge for some distance on the carapace. Merns of the chelipeds trigonous, armed anteriorly with four or five spines; carpus with two or three external ridges and a few pointed tubercles near the anterior end; hand with a strong spine above the upper hinge joint at the proximal end of a tuberculated costa; ridge on the posterior upper edge ending distally in a spine.

Width $4.5 \mathrm{in}$; length $2.5 \mathrm{in}$.

Gulf of California, west coast of Lower California.

A fine specimen of this species was taken by Miss Cook at Point Loma, California, which is the most northern locality from which it has been recorded. 


\section{Subtribe CATOMETOPA, or GRAPSOIDEA.}

Carapace wide in front, often subquadrate, sometimes subglobose, and truncated or arcuated anteriorly but not rostrate. The frout is usually wide and bent downward. Epistome short, often almost linear. The palp of the maxillipeds may be articulated at the apex or at the inner or outer angle of the merus. Branchir generally less than nine; efferent branchial channels as in the Maioidea. Verges in the male in the coxø, sternum, or in the coxæ of the last pair of legs, thence passing through channel in the sternum beneath the pleon.

This group contains four families, the Gecarcinidæ, Ocypodidæ, Grapsidæ and Pinnotheridæ. The first family, the Gecarcinidæ, includes land crabs and is not represented by any species within our limits, although there are several in Lower California and Mexico.

\section{Family OCYPODID $\approx$.}

Carapace moderately convex, cancroid or trapezoidal in form, with the antero-lateral margins straight or rounded, and the branchial regions not greatly dilated. Front of moderate width or very narrow. Orbits and eye-stalks of moderate size or greatly developed. Palp of external maxillipeds joined to the antero-internal or rarely the antero-external angle of the merus. Dactyls of the ambulatory legs styliform and devoid of spines. The abdomen usually does not cover the whole width of the sternum between the last pair of legs.

Species mostly small and littoral.

\section{Genus Uca Leach.}

Carapace transverse, widest in front, the antero-lateral angles acute; dorsal surface smooth and granulated. Orbits large, extending to the lateral angles; eye-stalks long and slender. Merus of the maxillipeds generally transverse, smaller than the ischium, distally truncated, and not emarginate at the antero-interual angle; palp joined to the anteroexternal angle of the merus. Chelipeds in the male very unequal; hand in the larger cheliped very large, fiugers longer than the palm. Smaller cheliped (both chelipeds in the female) feeble. 
Uca crenulata (Lock.)

Pe.I. f. . - 9 .

Gelasimus crenulatus Lockington, Proc. Cal. Acad. Sci., Vol. VII, 1877, p. 149.

Gelasimus vocator Kingsley (not Herbst), Proc. Acad. Nat. Sci. Phila., 1580, p. 147 .

Gelasimus gracilis Rathbon M., Proc. U. S. Nat. Mus., Vol. XVI, 1893, p. 244.

Uca vocator Ortmann (not Herbst), Zool. Jahrb. Abth. f. Syst., Bd. X, 1897 , p. 352.

Uca gracilis Rathbun MI., Proc. U. S. Nat. Mus., Vol. XXI, 1898, p. 603.

Carapace smooth, convex, with the $\mathrm{H}$-shaped impression prominent. Front wide. The lower edge of the superior orbital margin is arched forward morestrongly in the middle than the upper one. Lateral margins nearly parallel for a short distance behind the prominent antero-lateral angles of the carapace and then converging. Merus of the maxillipeds much broader than long and much shorter than the ischium. Merus of the large cheliped with the inner margin denticulated and the outer surface crossed by transverse granulated rugæ; carpus with the outer surface granulated and the inner surface crossed by an oblique, usually granulated ridge; hand finely granulated on the outer surface; inner surface with a granulated or tuberculated ridge running from the lower margin to the carpal groove; there is often a line of granulations extending from the upper end of this ridge towards the upper margin of the hand; the carpal groove is deep and covered by the overhanging upper edge of the palm; fingers long and slender; the pollex is nearly straight or bent slightly upwards, and truncated at the tip; dactyl longer than the pollex, curving most strongly near the tip and generally armed with a tooth near the middle of the inner margin. Ambulatory legs pubescent, the merus transversely ringose. Abdomen of the male seven-jointed, the second joint very short.

Todos Santos Bay near San Diego (Lockington); La Paz, Lower California! Guaymas! Sonora, Mexico! San Luis Gonzales Bay! Todos Santos Bay, La Paz, Lower California, San Diego (Miss Rathbun).

The specimens of Miss Rathbun from La Paz and San Luis Gonzales Bay I have seen, and also Mr. Lockington's types. The other specimens examined were in Lockington's collection.

This species is closely allied to pugnax Smith, but is distinguished by the more convex carapace, which is 
much wider behind; by the narrower abdomen in the male with the shorter second segment; by the more slender fingers in the large cheliped, and the more slender merus joints in the ambulatory legs. It may be distinguished from coloradensis Rathbun by its darker and more convex carapace, the more slender merus joints in the ambulatory legs, and by the different curvature of the upper side of the palm in the large cheliped. It is a much smaller species than brevifrons Stimpson, and has a relatively wider and more convex carapace and very different upper orbital margins.

\section{Uca rectilata (Lock.) Pl.I. f. $10-14$.}

Gelasimus rectilatus Lockington, Proc. Cal. Acad. Sci., Vol. VII, 1877, p. 148.

Gelasimus annulipes Kingsley (not Milne-Edwards), Proc. Acad. Nat. Sci. Phila., 1880, p. 148.

Carapace wide, nearly flat transversely, but longitudinally strongly convex. Front broad and arched strongly forwards. The upper edge of the superior orbital margin is strongly curved; the lower edge runs close to the upper but is distinct; the lower margin of the orbit is prominently denticulated, especially at the rounded outer angle. Postorbital angle prominent, acute, and directed obliquely outwards; the lateral margins of the carapace are straight, converging from the postorbital angles to the straight posterior margin. Maxillipeds with the ischium large, smooth, strongly convex; merus oblique, much wider than long, but narrower than the ischium and about one-third its length. A longitudinal groove on either side of the buccal area. Merus of the larger cheliped but slightly rugose with the angles rounded; carpus lightly granulated on the upper surface; hand similar to that of crenulata; the outer surface of the palm finely granulated and the lower edge margined; an oblique, granulated ridge on the inner surface extending from the lower margin to the deep carpal groove; no oblique ridge above this one as in crenulata; two parallel lines of granules behind the articulation of the dactyl, the posterior of which is continued upon the pollex; pollex tapering, a tooth near the middle, the extremity slightly excavated; dactyl curved more strongly toward the tip, which slightly overreaches the pollex. Ambulatory legs slender. Abdomen of the male seven-jointed, the first two joints short. 
Length of carapace, male................. $8.75 \mathrm{~mm}$.

Width of carapace, male ..................... $13.5 \mathrm{~mm}$.

Length of larger hand, male.............. $19 \mathrm{~mm}$.

Length of carapace, female............... $7.75 \mathrm{~mm}$.

Width of carapace, female................ $12.25 \mathrm{~mm}$.

Described from Lockington's types (Cat. No. 3112) in the collection of the California Academy of Sciences.

West coast of Lower California (Lockington).

This species differs from U. gibbosa (Smith) in having the surface of the carapace even, with the branchial regions not at all inflated, and in having seven, instead of five, abdominal segments in the male.

$U$. stenodactyla is reported from San Diego by Ortmann, who unites with this species gibbosa (Smith) and speciosa Ives $^{1}$.

\section{Genus Speocarcinus Stimpson.}

Carapace longitudinally convex both in front and behind, transversely nearly plane; sides converging behind. The space between the outer ends of the orbit exceeds one-half the width of the carapace. Antero-lateral margins dentate. Ocular peduncles of moderate length; eyes small. Orbits and antennæ similar to those of Panopeus. Palate devoid of a median elevation. Maxillipeds widely gaping; merus rather short and bearing the palp at the summit. Chelipeds short and stout. Ambulatory legs slender, smooth, with depressed, ciliated dactyls. Genital openings of the male in the sternum.

Abdomen of the male with the base much narrower than the last thoracic sternum; third, fourth and fifth segments coalesced.

Type.-S. carolinensis Stimpsos.

\section{Speocarcinus californiensis (Lock.)}

Eucrate ? californiensis Lockingtox, Proc. Cal. Acad. Sci., Vol. VII, 1877, p. 33.

Carapace strongly convex longitudinally, transversely plane, nearly smooth above, but minutely granulated towards the pubescent margins. Median region divided into three areas by pubescent sulci; a longitudinal, pubescent line on the branchial regions which are separated from the

1 See Zool. Jahrb. Abth. f. Syst., Bd. X, 1897, p. 356. 
hepatic by a transverse sulcus. Front over one-fourth the width of the carapace, the anterior margin straight and emarginate in the center. Upper margin of the orbit nearly straight, not interrupted by fissures; lower margin with an external fissure and a rounded inner lobe. Ocular peduncles slender and about two-thirds as long as the width of the front and furnished anteriorly with two converging rows of long hairs. Anterolateral margin strongly curved and furnished with three teeth (including the postorbital), the first two of which are thin-edged and lobate, the second one broadly rounded; the last tooth is acute. Buccal area widened in front. External maxillipeds diverging anteriorly, the merus distally truncated, with the antero-external angle rounded and not produced. Chelipeds unequal; merus short, thick, trigonous, with the edges granulated, and furnished with a prominent tooth at the supero-distal angle; carpus with a spine at the antero-internal angle and a short, longitudinal, granulated ridge at the distal end of the outer surface; hands wide, mugh compressed, the outer surface nearly smooth but granulated near the upper and lower margins; upper edge acute and sharply granulated; fingers ridged, the pollex not deflexed. Legs smooth, glossy, pubescent; dactyls slender with strongly pubescent margins, the last pair and to a less extent the preceding pair npturned. First segment of the abdomen in the male short and wide, but much narrower than the last thoracic sternum; second segment a little longer but markedly narrower than the first; third segment as wide proximally as the first, the sides converging rapidly to the coalesced fourth segment; remaining segments tapering gradually to the rounded extremity.

Length of carapace.......................... $16 \mathrm{~mm}$.

Width of carapace........................... $21 \mathrm{~mm}$.

San Pedro, California. Lives in holes on muddy beaches.

Quite closely allied to carolinensis St. from the Atlantic coast, but is distinguished by having three instead of five antero-lateral teeth, and by its longer eyepeduncles. From granulimanus Rath. it differs in the number of antero-lateral teeth, the smoother hands, and in having the antero-external angle of the merus rounded and not produced.

\section{Family GRAPSID $Æ$.}

Carapace depressed or moderately convex, more or less quadrilateral, the lateral margins straight or slightly arcuate. Front usually broad, never very narrow. Orbits and eye-stalks of moderate size. Palp of the 
maxillipeds joined to the summit or antero-external angle of the merus. Chelipeds in the adult male subequal and quite well developed; dactyls of the ambulatory legs styliform, compressed, and armed with strong spines. The base of the abdomen in the male usually covers the whole width of the last thoracic sternum.

The species, with rare exceptions, are littoral or inhabitants of shallow water.

Carapace striated.

Orbits normal. ..................... Pachygrapsus.

Orbits bulged outward.................. Grapsodius.

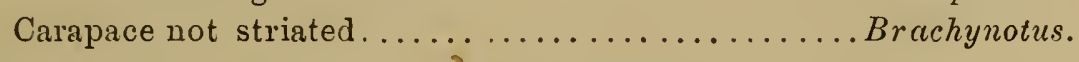

\section{Genus Pachygrapsus Randall.}

Carapace trapezoidal, depressed, and marked with transverse striæ. Front depressed and over one-half the width of the carapace. Inferior subocular lobe small, not reaching the front, thus allowing the antennæ to enter the orbit. Eye-peduncles short and stout. Maxillipeds devoid of a piliferous ridge and having a wide rhomboidal gap between them; merus as broad as or broader than long, distally truncated and bearing the palp at the summit. Chelipeds subequal, the merus trigonal, with the anterior margin distally dentated. Legs of moderate length, merus dilated and compressed, and furnished with an anterior subterminal tooth or spine; dactyls more or less spinulous. Antero-lateral margins entire or with one or two teeth. Abdomen in the male seven-jointed and covering the whole width of the last thoracic sternum.

Type.-P. crassipes Raxdall.

\section{Pachygrapsus crassipes Randall.}

Pachygrapsus crassipes Raxdall, Journ. Acad. Nat. Sci. Phila., Vol. VIII, 1839, p. 127. H. Milne-Edwards, Ann. Sci. Nat. (3), T. XX, 1853, p. 166. Stimpsor, Journ. Bost. Soc. Nat. Hist., Vol. VI, 1857, p. 467. Lockington, Proc. Cal. Acad. Sci., Vol. VII, 1877, p. 153. Streets, Bull. U. S. Nat. Mus., No. 7, 1877, p. 115 . Kingsley, Proc. Acad. Nat. Sci. Phila., 1880, p. 199. DE MAx, Notes Leyden Mus., Vol. XII, 1890, p. 86, Tab. V, fig. 11. ORtuaxn, Zool. Jahrb. Abth.f. Syst., Bd. VII, 1894, p. 707. Rathbun M., Proc. U. S. Nat. Mus., Vol. XXI, 1898, p. 604 .

Carapace nearly square (the sides converging slightly posteriorly), moderately convex, the entire upper surface, except the cardiac and intestinal regions, transversely striated. The front is broad, depressed, slightly 
arcuated; a single tooth at the outer angle of the front; behind the front are four lobe-like prominences, the two middle ones the more conspicuous, and separated from each other by a groove whose sides are marked with sharp lines. A single tooth on the lateral margin behind the prominent postorbital. The notch at the infero-external angle of the orbit is deep. Orbits deep, the inferior margins strongly granulated. Antennæ minute. Merus of the maxillipeds quite strongly produced at the antero-internal angle; first joint of the palp large and compressed. Merus of the chelipeds short, trigonal, and transversely rugulose, the anterior margin laminate and armed at the distal end with three teeth; carpus finely rugose externally and bearing a tooth or tubercle at the antero-internal angle; hand in the adult male larger than all the preceding joints combined; a raised line usually present on the upper side of the palm and a delicate line on the lower portion of the outer surface. Merus joints of the legs transversely rugulose, strongly compressed and expanded, especially in the last three pairs, the postero-distal angles in the anterior pairs armed with a variable number of teeth; in the last or last two pairs they are rounded and usually edentate; dactyls short, compressed, and spinous on both margins. Third joint of the abdomen in the male strongly convex at the sides; following joints increasing successively in length.

Length of carapace, male.................... $36.5 \mathrm{~mm}$.

Breadth of carapace, male................. $41 \mathrm{~mm}$.

Length of carapace, female................ $30 \mathrm{~mm}$.

Breadth of carapace, female............... $34 \mathrm{~mm}$.

Japan (Stimpson, Ortmann), Sandwich Islands (Randall), Oregon! northern California! San Francisco Bay! Monterey! San Diego! Gulf of California (De Man). A very common species on rocky shores.

This species was originally reported by Randall from the Sandwich Islands, where it has not since been found. On the other hand, P. parallelus, which Randall reported as coming from the Columbia River, has not since been found on the west coast of the United States. It is probable, as Stimpson suggests, that the labels of the two species were accidentally exchanged. Several other species reported from this coast by Randall have not since come to light. Possibly mixing of labels has occurred in other cases also. 


\section{Genus Brachynotus De Haan.}

Carapace subquadrate, not markedly striated, and having two teeth behind the orbital angle. Front wide, not strongly deflexed. Maxillipeds without a wide rhomboidal gap; ischium transversely truncated; merus large and not produced at the antero-external angle; palp joined in a notch at the middle of the distal margin.

T'ype.-B. sexdentatus (Rrsso).

\section{Brachynotus nudus (Dana).}

Pseudograpsus nudus Dana, Proc. Acad. Nat. Sci. Phila., 1851, p. 249; Crust. U. S. Expl. Expd., Part 1, 1852, p. 335, Pl. XX, fig. 7. StimPsox, Journ. Bost. Soc. Nat. Hist., Vol. VI, 1857, p. 469.

Heterograpsus nudus Stmpson, Proc. Acad. Nat. Sci. Phila., 1858. p. 104. Lockington, Proc. Cal. Acad. Sci., Vol. VII, 1877, p. 152. Whiteaves, Can. Nat. (2), Vol. VIII, 1878, p. 471. Sмiтh, Rep. Prog. Geol. Surv. Canada, 1878-9, B, p. 206. Rathbon R., The Fisheries of the U. S., Sec. 1, 1884, p. 765. Newcombe, Bull. Nat. Hist. Soc. Brit. Col., 1895, p. 25. Ortmann, Zool. Jahrb. Abth. f. Syst., Bd. VII, 1894, p. 715. Walker, Traus. Liverpool Biol. Soc., Vol. XII, 1898, p. 273.

Heterograpsus sanguineus Krngslex (not De HaAN), Proc. Acad. Nat. Sci. Phila., 1880, p. 20 s.

Carapace posteriorly flat, smooth and punctate, anteriorly convex, undulated, and furnished with small, scattered granules. A curved line of light-colored pits extending from the auterior end of the H-shaped impression to the last autero-lateral tooth. Front bilobed, the median emargination shallow, but comparatively broad. The two transverse prominences behind the front are evenly rounded. Antero-lateral margins strongly arcuated and granulated; the second tooth behind the acute postorbital much smaller than the preceding ones. Posterior margin of the epistome granulated, the arcuated median portion separated from the subquadrate, projecting, lateral portions by a conspicuous, deep, smooth interval. On the pterygostomian regions a ridge running parallel with the antero-lateral margin and armed with numerous smooth, small, rounded denticles or granulations. Maxillipeds punctated; a groove behind the broad, raised, inuer margin of the merus. Chelipeds smooth, and mottled above with small, roumd, red spots; antero-internal angle of the merus in the adult male produced into a rounded, smooth lobe; carpus with a subacute prominence on the inner side; hands smooth, with a fine longitudinal ridge along the lower side of the outer surface; fingers with small, corneous tips. In the males the hands are inflated and bear a large 
patch of long, fine hair on the inner surface. Legs rather short, smooth, punctate and nude; dactyls short, stout, scabrous; those of the last pair less than two and one-half times (often less than twice) as long as wide, and upturned at the tip.

The color of this species is quite variable. It is generally of a mahogany red, but may be purplish, dark red, or red marbled with white. I have seen some specimens with the upper side almost entirely white. But amid all the variations of color, the red spots on the chelipeds remain, so far as I can determine, an absolutely constant character. Young specimens present greater color variations than older ones.

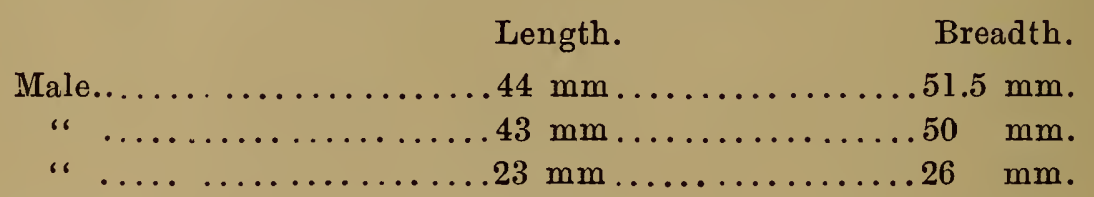

Female. ..............22 $\mathrm{mm} \ldots \ldots \ldots \ldots 25.5 \mathrm{~mm}$.

Sitka (Kingsley); Vancouver's Island (Smith); Puget Sound; common from Oregon to Lower California; Gulf of California (Kingsley). Found among rocks near the shore.

This species differs from sanguineus (De Haan), with which it has been united by Kingsley, in having a tuft of hair on the inner side of the hand in the male, and in the different inferior orbital margin.

\section{Brachynotus oregonensis (Dana).}

Pseudograpsus oregonensis Dana, Proc. Acad. Nat. Sci. Phila., 1851, p. 248; Crust. U. S. Expl. Expd., Part I, 1852, p. 334, Pl. XX, fig. 6. Stimpson, Proc. Cal. Acad. Sci., Vol. I, 1856, p. S8; Journ. Bost. Soc. Nat. Hist., Vol. VI, 1857, p. 468 . Milne-Edwards, Anu. Sci. Nat. (3), Zool., T. XX, p. 157. Cooper, Rep. Expl. and Sur. to Pac. Ocean, Vol. XII, 1860, Book 2, p. 389. Strmpson, Proc. Acad. Nat. Sci. Phila., 1858, p. 104. Lockington, Proc. Cal. Acad. Sci., Vol. VII, 1876, p. 152. Kingsley, Proc. Acad. Nat. Sci. Phila., 1880, p. 209. Ratinun, R., The Fisheries of the U.S., 1884, Sec. 1, p. 765. 
Carapace more strongly undulated in front than in nudus but not so much flattened behind; the posterior portion is not punctate and the anterior portion may be sparsely granulated. Front four-lobed, the median lobes the most prominent. The median portion of the epistome is not granulated nor separated from the lateral portions by a deep smooth interval. The ridge on the pterygostomian region furnished with several smooth, blunt teeth. The prominences behind the front are more conspicuous than in nudus and sometimes end abruptly anteriorly. External maxillipeds smooth and punctated; surface of the merus next to the inner margin flat. Chelipeds smooth; carpus with a prominent inner angle; hands with a fine longitudinal ridge on the lower part of the lower surface which becomes very faint with age. In the adult male there is a rounded lobe on the antero-internal of the merus and a patch of long hair on the inner side of the hand. Legs bairy, the dactyls narrower than in nudus, those of the last pair upturned.

The color is a dull gray mottled with ferruginous spots. The spots on the legs are small, but there may be blotches of considerable size on the carapace. The color is not so variable as in the preceding species although very young specimens are occasionally marked with large blotches of white.

Length, $23 \mathrm{~mm}$; breadth, $28 \mathrm{~mm}$.

This species may readily be distinguished from the preceding by its dull color, the hairiness of the legs, the four-lobed front, and the absence of round red spots on the chelipeds so characteristic of that closely related species. Nudus is found chiefly among the rocks, while oregonensis prefers the mud flats, where it is usually found in abundance.

Vancouver's Island. Common on mud flats from Puget Sound to Lower California., It is also found among rocks near the shore.

\section{Grapsodius, gen. nov.}

Carapace striated above, with the sides converging behind, and armed with a single tooth behind the postorbital. Front broad, not deflexed, but with the median portion depressed. Eye-peduncles short. Orbits with the posterior surface bulging outwards instead of concave. Maxillipeds narrow, widely gaping, and devoid of an oblique piliferous ridge; merus 
subcordate, shorter than the ischium, the antero-internal angle produced; palp joined near the middle of the distal margin of the merus. Dactyls spinulous. Abdomen of the male seven-jointed.

Type.-G. eximius HoLmes.

\section{Grapsodius eximius, sp.-noi.}

ec. Carapace undulated in front and flattened behind where it is more strongly striated; sides strongly converging posteriorly. The front is over one-half the width of the carapace and has the outer angles more or less projecting and rounded; the anterior edge is thin and minutely granulated; viewed from above it is nearly straight, being slightly convex on either side of the middle where it is a little concave; viewed from in front it sags downward in the center. The orbits are remarkable in being swollen outward so that there is no hollow receptacle, as is usually the case, for the reception of the eyes; the superioi orbital margin is marked by a fine ridge extending from the outer side of the front to the postorbital tooth; the inferior orbital margin is marked by a line of granules extending from the lower side of the postorbital tooth to the buccal area. Maxillipeds slender and wide apart. The ischium is much longer than the merus but not so wide; merus with the outer margin convex and the antero-external angle broadly rounded; the inner margin is straight and the antero-internal angle is produced into a prominent narrow lobe; first joint of the palp strongly convex near the middle of the inner margin; exognath at the base about one-half as wide as the ischium and tapering regularly to the tip which reaches slightly beyond the middle of the merus. Chelipeds subequal; merus short, trigonal, the outer surface transversely striated, the inner margin produced into a laminate expansion which is distally truncated and dentate; carpus with a spine near the middle of the upper margin; hands smooth and inflated; the upper margin of the palm is broadly rounded, but bears a fine ridge; a very fine ridge on the lower side of the outer surface extending upon the pollex; fingers subcylindrical, not ridged or grooved, and armed within with small teeth. Merus of the ambulatory legs dilated and compressed much as in Pachygrapsus crassipes, with the upper margins acute and ending in a tooth a little behind the supero-distal angle; the infero-distal angle, in all but the last pair, is dentate; carpal joints with a few small spines near the distal end of the upper margin; propodi with the sides strongly convex and the upper and lower margins spiny; dactyls rather narrow, shorter than the propodi, strongly spinose above and below, and terminating in slender claws. The abdomen in the male is widest at the thind segment, behind which it tapers to the tip, the sides converging more rapidly towards the posterior end; first segment much longer than the second; third segment about as long 
as the fourth, the sides strongly convex; fifth segment scarcely longer than the fourth and shorter than the sixth; last segment triangular, acute.

Length of carapace, $18.5 \mathrm{~mm}$; width of carapace, $21 \mathrm{~mm}$; width of front, $11.2 \mathrm{~mm}$.

San Diego, California. Collected by A. U. Crawford.

This species is described from a single dried and somewhat imperfect specimen contained in the Museum of the University of California. The form and arrangement of the antennæ and antennules could not be determined, nor could I make out whether or not the inferior orbital lobe was in contact with the front. The front, legs, maxillipeds, and striations on the carapace are similar to those of Pachygrapsus, but the character of the orbits separates it from that genus as. well as all the other genera of the Grapsidæ.

\section{Family PINNOTHERID $Æ$.}

Carapace convex or depressed, often more or less membranaceous, the antero-lateral margins entire or very slightly dentate. Front narrow. Orbits and eye-peduncles very small. Buccal area convex anteriorly. The merus and often the ischium of the maxillipeds is well developed, and the palp may be joined to the summit, antero-internal angle, or, rarely, the antero-external augle of the merus. Chelipeds usually small, or of moderate size. Ambulatory legs variable; dactyls generally styliform and not armed with spines.

The members of this family are generally of small size, and most of them inhabit the shells of bivalved molluscs. Some species inhabit the intestine of echinoderms and others the tubes of annelid worms. The Pinnotheridæ are divided by Miers into four subfamilies, only two of which are found in our limits.

\section{Subfamily PINNOTHERINÆ.}

Carapace usually convex, subglobose, or transverse. Front not ros. trated. Ischium of the maxillipeds rudimentary or absent. The ambulatory legs are all well developed (the last pair is sometimes small); dactyls often short. 


\section{Genus Pinnotheres Latr.}

Carapace smooth, subglobose, more or less membranaceous and scarcely wider than long. Orbits small, nearly circular. Front narrow, with the anterior margin nearly straight. Antenuules transverse. Maxillipeds oblique, the merus large, usually curved, the last joint of the palp joined to the inver margin of the preceding one. Ambulatory legs subequal and of moderate length.

\section{Pinnotheres nudus Holmes.}

Pinnotheres nudus Holmes, Proc. Cal. Acad. Sci., 2d Ser., Vol. IV, 1895, p. 563, figs. 1-5.

Carapace a little broader than long, subquadrate to orbicular in outline, curving downwards towards all the margins; surface smooth and naked. Front rounded, deflexed, not protruding. Orbits ovate. Antennules oblique. Maxillipeds oblique, neatly fitting the buccal area; merus broad, smooth, subquadrate, the outer margin produced into a broadly rounded, laminate expansion; penultimate joint oblong and distally rounded; last joint spatulate, articulated near the base of, and extending somewhat beyond the preceding one. Chelipeds rounded, smooth, devoid of spines or teeth; hands narrow, rather thick; fingers subconical, subequal to the palm. The three anterior pairs of ambulatory legs subequal; dactyls nearly straight; those of the fourth pair longer and more slender than the other's.

Length, $20 \mathrm{~mm}$; breadth, $24 \mathrm{~mm}$.

\section{Santa Cruz (Dr. Anderson's Coll.)! Monterey!}

\section{Pinnotheres pugettensis, sp. nov.}

Carapace soft, smooth, subpentagonal. Front triangular, acute, curved downwards, scarcely protruding beyond the general contour of the carapace. Orbits nearly circular. Antennæ shorter than one-half the width of the front. Maxillipeds very oblique, strongly pubescent; merus narrower than in nudus, the outer margin convex; penultirnate joint broad, subquadrate, distally truncated, last joint minute, joined slightly in advance of the middle of the preceding one but scarcely reaching beyond the tip. Chelipeds smooth; merus short, the upper margin furnished with loug hairs; hands narrow, elongated, rounded, smooth, the dactyls and iuner side of the palm short/pubescent; fingers subcylindrical, nearly straight, a little shorter than the palm, the tips strongly hooked, dactyl with a low tooth near the base of the inner margin. Ambulatory legs slender, increasing slightly in length posteriorly; propodi hairy above and 
below; dactyls narrow, compressed, convex above, abruptly contracted near the tip into a short, curved claw; in the three anterior pairs the dactyls are shorter than the propodi and leave the lower margin neariy straight; in the last pair the dactyl is much longer than the propodus, much longer than the preceding dactyls, and has the lower margin concave. The outer surface of the palm is brownish with light-colored reticulations.

Length of carapace, $10 \mathrm{~mm}$; ; length of first ambulatory leg, $9.5 \mathrm{~mm}$. Width of carapace, $10.5 \mathrm{~mm}$; l length of last ambulatory leg, $10.5 \mathrm{~mm}$.

Described from a single female specimen found by Professor W. E. Ritter in the branchial cavity of a species of Cynthia from Puget Sound. Collection of the University of California.

\section{Genus Fabia Dana.}

Closely allied to Pinnotheres. Carapace smooth, more or less membranaceous, not much broader than long, and marked by a pair of longitudinal sulci which extend backward from the upper margin of the orbits, enclosing between them the median area. Front not rostrated. Eyes normal, not widely separated. Antennulary fossettes not widely separated. Maxillipeds with the merus large and the ischium rudimentary; third joint of the palp articulated on the inner margin of the preceding one. Ambulatory legs subequal and rather sleuder; dactyls short.

Type.-F. subquadrata DaNA.

This genus differs from Pinnotheres in no important character except the longitudinal sulci on the carapace.

\section{Fabia subquadrata Dana.}

Fabia subquadrata Dana, Proc. Acad. Nat. Sci. Phila., 1851, p. 253; Crust. U. S. Expl. Expd., Part I, 1852, p. 382, Pl. XXIV, fig. 5. Strmpsox, Journ. Bost. Soc. Nat. Hist., Vol. VI, 1857, p. 470. Lockixgtos, Proc. Cal. Acad. Sci., Vol. VII, 1877, p. 155. Sмiтh, Rep. Prog. Geol. Surv. Canada, 1878-9, B, p. 206. Newcombe, Bull. Nat. Hist. Soc. Brit. Col., 1893, p. 25.

Carapace smooth, glossy, membranaceous, subquadrate in outline, with the angles broadly rounded; the space between the longitudinal sulci is longer than wide and slightly narrowed behind; antero-lateral margin rounded and marked by a raised line. Front very short and turned 
abruptly downwards, having no trace of a median or transverse groove. Eye-stalks short, stout, rounded and lodged in nearly circular orbits. Antennules obliquely plicated in very wide fossettes. Antennæ minute. Maxillipeds very oblique; merus large, smooth, curved and distally rounded; the penultimate joint of the palp is broad, flattened, and bears the minute third joint near the middle of the inner margin. Chelipeds smooth and rather slender; hand long and narrow; palm about twice as long as wide, with the upper and lower margins parallel, and having one or two rows of hairs below, one of which reaches to the tip of the finger; fiugers longitudinal, subcylindrical, nearly straight, and shorter than the palm; dactyl with a tooth a little behind the middle of the inver margin. Legs slender, glossy, and nearly naked, but the upper side of the merus and the lower side of the propodus are generally more or less pubescent; dactyls pubescent, about half the length of the propodi, and subuncinate at the tip. Color in life, whitish; carapace and abdomen largely covered with orange.

Length of carapace, female, $11.5 \mathrm{~mm}$.; width, $13 \mathrm{~mm}$.

The following measurements are given by Dana from his specimen from Puget Sound: Length of carapace, 5.75 lines; breadth, 6.75 lines; breadth between post-frontal sutures, 2.25 lines; length of third joint of fourth pair of legs, 2.75 lines, or about two-fifths the breadth of the carapace.

Queen Charlotte Is. (Smith), Puget Sound (Dana), Farallon Is. and San Diego (Lockington), San Pedro! in shell of Tapes. It is found also in the shell of Pachydesma crassitelloides and sometimes in the tests of Echini.

\section{Genus Pinnixa White (emended).}

Carapace much wider than long. Front narrow, nearly transverse. Orbits broadly ovate or nearly circular, with a wide inner hiatus which is partly occupied by the basal antennal joints. Antennules trausversely or obliquely plicated in wide fossettes which communicate with each other beneath the front. Eye-stalks very short. Epistome linear-transverse. Ischium of the maxillipeds small; merus large, the distal portion of the outer margin convex; palp joined to the summit of the merus, the third joint joined on the inner side of the preceding one near the base. Chelipeds of moderate size; merus trigonous; carpus smooth; hand large, com. pressed. Second ambulatory legs larger than the first; the third pair is the largest of all; fourth pair much shorter than the third and relatively stouter than the first and second. . The abdomen in both sexes is sevenjointed and narrower at the base than the width of the last thoracic sternum.

T'ype.-P. cylindrica SAY. 


\section{Pinnixa occidentalis Rath.}

Pinnixa occidentalis Rathbun, Proc. U. S. Nat. Mus., Vol. XVI, 1893, p.

248. Newcombe, Bull. Nat. Hist. Soc. Brit. Col., 1893, p. 26.

Male: Carapace nneven, about $t$ wice as wide as long; median region tumid and bounded by sulci on either side and behind; a transverse crest on the cardiac region which is not interrupted in the middle but becomes lower and curves backwards. Behind this crest, which is more prominent in the male, the carapace slopes rapidly downward, being nearly at right angles to the surface in front of it. Front narrow, depressed, furnished with a median groove, and not projecting beyond the general contour of the carapace; a pair of prominences behind the anterior margin which is slightly produced at the center. The antero-lateral margin is marked by a sharp, more or less gramulated line which begins a short distance external to the orbit and meets the postero-lateral margin at a little less than a right angle. Antennæ longer than the width of the front. Maxillipeds nearly longitudinal; second joint of the palp narrow (over twice as long as wide), and tapering slightly from the base to the rounded tip; last joint narrowly spatulate (about four times as long as broad), joined near the base of and extending much beyond the preceding one; outer surface of the last two joints sulcated. Chelipeds stout; hand broad, smooth and shining, slightly widened distally, the upper and lower margins rounded and scabrous; pollex broad, short, deflexed and furnished with one or more teeth on the inner margin; dactyl much curved, sometimes having a minute tooth near the middle of the inner margin. The first pair of ambulatory legs is slender, having slender dactyls which are subequal to the preceding joint; second pair similar to the first but longer and stouter; third pair longer and much stouter than the second, but more slender than in tubicola or littoralis; the dactyls slender, almost straight, and about equal to the propodi; fifth pair stouter than the first and nearly as long, reaching considerably beyond the merus of the preceding pair; dactyls slender, straight, and about equaling the propodi. The abdomen tapers gradually from the second segment to the last, which is rounded; the third, fourth, and fifth segments are subequal and slightly louger than the sixth. The appendages and sides of the carapace are more or less pubescent. The upper and lower margins and, to a less extent, the surfaces of the ambulatory legs, are scabrous.

Length of Carapace. Breadth of Carapace. Length of Third Ambulatory Leg.
Male ........
$7 \mathrm{~mm}$. $19 \mathrm{~mm}$.
“ ...... $9.5 \mathrm{~mm} \ldots \ldots \ldots \ldots \ldots 19.5 \mathrm{~mm} \ldots \ldots \ldots \ldots 27 \mathrm{~mm}$.

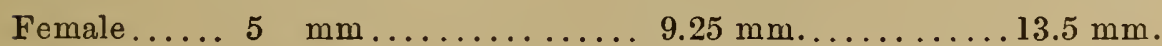
“ $\quad \ldots \quad \ldots 10.5 \mathrm{~mm} \ldots \ldots \ldots \ldots \ldots .20 .5 \mathrm{~mm} \ldots \ldots \ldots \ldots 24 \mathrm{~mm}$. 


\section{Described from specimens received from Miss Rath- bun.}

Alaska to Washington, San Diego (Rathbun); British Columbia (Newcombe).

In the female the carapace is more tumid and the chelipeds smaller. One small female which I collected on the coast of Humboldt County, Calif., had the carapace entirely covered with a short pubescence.

\section{Pinnixa californiensis Rath.}

Pinnixa californiensis Rathbur M., Proc. U.S. Nat. Mus., Vol. XVI, 1893, p. 249; and Vol. XXI, 1898, p. 605.

This species is very closely allied to occidentalis, but the carapace is relatively wider and more flattened above, the cardiac ridge does not curve backwards so strongly in the middle, the antero-lateral ridge is straighter, and curves backward more abruptly toward the outer end, the median region is less tumid, and the carapace descends more abruptly at the sides. The second abdominal segments in the males of the two species that I have do not present any appreciable differences, although in the specimens described by Miss Rathbun the sides of that segment were parallel in californiensis and divergent posteriorly in occidentalis. The ambulatory legs are almost exactly alike in the two species and differ much from those of the other Pinnixas on our coast.

Length of Carapace. Breadth of Carapace. Length of Third A mbulatory Leg.

Male ......4.75 $\mathrm{mm} . . . . \ldots \ldots . .10 \mathrm{~mm} . \ldots \ldots \ldots . .13 \mathrm{~mm}$.

Female....4.5 $\mathrm{mm} \ldots \ldots . \ldots . .9 .75 \mathrm{~mm} \ldots \ldots \ldots . \ldots 12 \mathrm{~mm}$.

Described from specimens received from Miss Rathbun.

Monterey Bay and off Point Ano Nuevo, California; Magdalena Bay, Lower California (Rathbun). The locality of the specimens described is lat. $36^{\circ} 47^{\prime} 50^{\prime \prime} \mathrm{N}$.; lon. $121^{\circ} 49^{\prime \prime} \mathrm{W}$.; depth, 37 fathoms. 


\section{Pinnixa tubicola Holmes.}

Pinnixa tubicola Holmes, Proc. Cal. Acad. Sci., 2d Ser., Vol. IV, 1895, p. 569, $\mathrm{Pl}, \mathrm{XX}$, figs. 17 and 18 .

General form subcylindrical. Carapace about two and one-half times. as Iong as wide, strongly curved downward towards the anterior margin and at the sides. A shallow, transverse depression behind the gastric area, behind which is a convex (not crested) transverse intumescence, from which the carapace curves sharply downwards towards the broad, slightly concave posterior margin. Front short, deflexed, not projecting. beyond the general contour of the carapace. Outer portion of the anterolateral margins defined by a ridge. The last joint of the palp of the maxillipeds is spatulate and joined near the base of, and extending considerably beyond the preceding one. Chelipeds rather small; hand oblong, longer than the preceding joints combined; fingers hooked at the tips, their inner margins meeting when closed. First pair of ambulatory legs slender, with slender dactyls which about equal the length of the propodi; second pair much longer and stouter than the first, the dactyls relatively stouter than in the first pair and a little shorter than the propodi; third pair stouter and a little longer than the second and furnished with shorter and stouter dactyls, which are markedly shorter than the propodi; fourth pair similar to but much shorter than the third.

Length of carapace, $4 \mathrm{~mm}$; width, $10 \mathrm{~mm}$.

Puget Sound! Trinidad! Cape Mendocino! Bodega Bay! San Pedro! San Diego!

\section{Pinnixa littoralis Holmes.}

Pinnixa littoralis Holmes, Proc. Cal. Acad. Sci., 2d Ser., Vol. IV, 1895, p. 571, Pl. XX, figs. 14-16.

Carapace naked, flattened above; a transverse depression behind the median region followed by a transverse intumescence. The front is not strongly depressed and projects beyond the general outline of the carapace; it is anteriorly truncated and furnished with a median groove. Maxillipeds similar to those of tubicola; the terminal joint extends only a short distance beyond the preceding one. Chelipeds large, smooth; hand large, compressed, oblong, but widening slightly distally; pollex short, directed obliquely downwards and furnished at the tip with a notch, into which the point of the dactyl closes; dactyl curved, and when closed against the pollex, a large rounded space is left between them. Ambulatory legs almost entirely naked, more slender than in tubicola, first pair but little shorter than the second, which is but little shorter than the 
third; the dactyls in all the legs are little, if any, more than one-half the length of the propodi and are curved at their corneous tips. Abdomen of the male tapering evenly from the base to the tip; the sides of the penultimate joint are concave, those of the remaining joints straight.

Length of carapace, $4.5 \mathrm{~mm}$; breadth, $9.5 \mathrm{~mm}$; length of third ambulatory leg, $11 \mathrm{~mm}$.

\section{Bodega Bay! near Fort Bragg, California!}

\section{Pinnixa longipes (Lock.).}

Tubicola longipes Lockington, Proc. Cal. Acad. Sci., Vol. VII, 1877, p. 55. Pinnixa longipes Lockington, Ibid., Vol. VII, 1877, p. 156. Streets and

Kingsley, Bull. Essex Inst., Vol. IX, 1877, p. 107. Holmes, Proc. Cal. Acad. Sci., 2d Ser., Vol. IV, 1895, p. 573, Pl. XX, figs. 19 and 20.

Carapace considerably more than twice as wide as long, somewhat flattened above and furnished with a transverse depression behind the gastric area. Front slightly projecting, furnished with a median groove and a transverse groove behind the anterior margin. The last joint of the palp of the maxillipeds is spatulate and joined near the base of, and slightly exceeding the preceding joint. Chelipeds small, short, hairy; hands oblong, compressed. First two pairs of ambulatory legs slender (the secoud somewhat larger than the first), and furnished with slender, nearly straight dactyls which are about equal in length to the propodi; following pair of legs enormously developed; merus with a kind of flange on the posterior margin; dactyl stout, curved, much shorter than the propodus; last pair small and stout, scarcely reaching beyond the middle of the merus of the preceding pair; dactyl stout, curved, shorter than the propodus.

Tomales Bay (Lockington)! San Pedro, Calif.!

This species lives in the tube of an annelid worm (Clymenella). It forms the extreme point of modification of this peculiar genus. There is probably no other crab which has such great width relatively to its length, there is certainly no known species in which the fourth pair of pereopods is so enormously enlarged; and I believe there is no Brachyuran which exceeds it in smallness of size. 


\section{Pinnixa faba (Dana.)}

Pinnitheres faba Dana, Proc. Acad. Nat. Sci. Phila., 1851, p. 248; Crust. U. S. Expl. Expd., Part I, 1852, p. 3S1, Pl. XXIV, fig. 4. Bate, in Lord's Nat. in Vancouver's Island, Vol. II, 1866, p. 271.

Pinnixa faba Strmpson, Journ. Bost. Soc. Nat. Hist., Vol. VI, 1857, p. 470. Cooper, Rep. Expl. and Surv. Pac. Ocean, Vol. XII, Book 2, 1860, p. 387. Haswell, Cat. Anstralian Crust., p. 113. Newcombe, Bull. Nat. Hist. Soc. Brit. Col., 1893, p. 25.

Carapace strongly convex, both longitudinally and transversely; no transverse ridge behind the gastric area. Antero-lateral margins marked by a low ridge which disappears near the orbits." Front slightly projecting and divided into two rounded lobes. Antennules transversely plicated. Antenni much longer than the width of the front. The penultimate joint of the palp of the maxillipeds projects considerably beyoud the terminal one; both joints are more or less sulcate on the outer surface. Hands of the chelipeds flattened, widest just behind the articulation of the dactyl, and more or less pubescent on the inner side between the fingers; fingers gaping at the base; dactyl curved, acute and furnished with a tooth near the middle of the inner margin; and (generally) a row of hairs on the upper edge; pollex short, nearly straight, and obliquely truncated at the tip. First pair of ambulatory legs shorter than the second; dactyls subconical from a stont base and slightly curved; third pair longer and stouter than the second, the dactyl similar in form though stouter; last pair larger than in most of the species, the propodus reaching beyond the merus of the preceding pair; dactyls more slender than those of the third pair. Upper and lower edges of the ambulatory legs (generally) quite strongly pubescent. Abdomen of the male tapering evenly to the penultimate joint, which tapers more rapidly than the preceding ones; last joint about as long as wide and rounded at the tip.

Vancouver's Island (Smith); Queen Charlotte Island (Newcombe); Puget Sound (Dana); Shoalwater Bay (Cooper); San Pedro, Calif.!

Dr. H. P. Johnson found several specimens of this species in the cloaca of a large species of Holothurian, Liosoma arenata St. It more commonly occurs in the shells of large bivalved molluses. 


\section{Pinnixa (Scleroplax) granulata (Rath.).}

Scleroplax granulatus Rathbun M., Proc. U. S. Nat. Mus., Vol. XVI, 1893, p. 251.

Carapace strongly convex, curving downward towards all the margins; sides rounded. Front very narrow (not one-fifth the width of the carapace), somewhat produced, almost transverse (slightly convex in the center), and uniformly convex above, having no median or transverse groove. No prominences behind the front. Median region not marked by sulci. Surface of the carapace more or less granulated anteriorly and near the margins, elsewhere smooth and punctate. Antero-lateral margin defined by a finely granulated ridge which runs parallel to the inferior margin of the carapace until very near the point, where it disappears, when it bends toward the lower margin but is not continued far enough to meet it. Orbits nearly circular. Antennules nearly transverse. Maxillipeds nearly longitudinal; merus broad, not curved; second joint of the palp narrow and longer than the merus, tapering gradually to its rounded tip; third joint rather narrow, spatulate, joined near the base of, and slightly exceeding the preceding joint; both of the last joints are grooved on the outer surface and fringed with long hair. Chelipeds of the female small, granulated, shorter than the following legs; hands pubescent, of moderate size, margins rounded; palm more or less inflated; pollex nearly longitudinal; dactyl curved. Ambulatory legs slender, compressed, not markedly unequal; dactyls very long, slender, almost straight, about equaling the propodi in all the pairs, and furnished with long, sharp, corneous tips; the first pair is somewhat smaller than the second, which is smaller than the third pair. Abdomen of the female smooth and shining.

Length of carapace, female, $7.75 \mathrm{~mm}$; breadth, $10.75 \mathrm{~mm}$; length of third ambulatory leg, $11 \mathrm{~mm}$.

Ensenada, Lower California (Miss Rathbun); Bodega Bay, Calif.!

The genus Scleroplax cannot be sustained, I believe, as some undoubted Pinnixas have a hard carapace and there are transition forms between granulata, in which the third pair of ambulatory legs is but little larger than the others, and the species in which the third pair is greatly developed. There are similar gradations between the very wide forms like longipes and the narrower species like granulata and faba. 


\section{Genus Parapinnixa Holmes.}

Carapace much broader than long, the anterior margin nearly straight. Frontal process deflexed. Orbits nearly round. Antenuules transversely or obliquely plicated, the fossettes communicating with each other beneath the front. Buccal area small, subtriangular. Maxillipeds with the ischium rudimentary, the merus large, triangular; palp ffo 6 - $/$ i three-jointed, the last joint joined to the tip of the preceding one. First pair of ambulatory legs the largest, the others diminishing successively in length, the last pair being quite small. Abdomen of female small, not nearly covering the sternal area.

Type.-P. nitida (Lock.)

\section{Parapinnixa affinis, sp. nov.}

Closely allied to $P$. nitida, but the carapace is less than twice as wide as long, while in that species the width of the carapace is over twice its length; the surface of the carapace is smooth and shining and the anterior margin straight. Frout triangular, depressed, having a short median groore. Antennules oblique. Buccal area small, triangular, rounded in frout, the posterior portion partly covered by a projection of the sternum. Chelipeds stout, smooth; hand thickened, smooth, rounded above and below; dactyl hooked at the tip and armed with a small tooth near the middle of the inner margin, the upper side smooth; pollex with two teeth at the tip. First pair of ambulatory legs larger than the others; dactyls short and stout. Next two pairs comparatively sleuder, having longer dactyls; last pair small, reaching about to the tip of the merus of the preceding pair; dactyls short and stout. Abdomen of the female widest at the third segment, behind which its shape is triangular, the tip broadly rounded.

Described from a single female specimen collected at Dead Man's Island, San Pedro, Calif., by Mr. F. W. Bancroft, July, 1895. Collection of the University of California.

The maxillipeds in this species are similar to those of nitida. They were accidentally lost after I had removed them from the specimen; the palp appeared to have but two joints, but the examination was not made with sufficient care to make me feel sure of this point. 


\section{Genus Cryptophrys Rathbun.}

Carapace subpentagonal, hard, convex, not much broader than long. Front produced. Orbits nearly circular and lodged in the sides of the front, only a small part of them visible from above. Antennules oblique or transverse. Buccal area much curved. Maxillipeds very oblique, the distal extremities (not as is usual the inner margins) being opposite each other and separated by a space in which the palpi are lodged; ischium rudimentary; merus large and curved; palp two-jointed and joined to the antero-external angle of the merus. Chelipeds moderately stout, the palm in the male broad and inflated. Ambulatory legs compressed; first three pairs subequal; fourth pair shortest. The base of the abdomen in the male does not cover the whole of the last thoracic sternum.

Type.-C. concharum RATHBUN.

\section{Cryptophrys concharum Rath.}

Cryptophrys concharum Rathbon M., Proc. U. S. Nat. Mus., Vol. XVI, 1893, p. 250.

Carapace smooth, slightly longer than broad; a faint sulcus behind the gastric region but no longitudinal sulci as in pubescens. Front emarginate. Antennules large, nearly transverse. Ocular peduncles short, stont, and completely filling the orbits. Antero-lateral margins marked by a ciliated line. Sides of the carapace broadly rounded. Merus of the maxillipeds with the outer margin curved, the distal portion almost transverse; the last joint of the palp four-sided, the extremity widened. Chelipeds and ambulatory legs margined by a row of coarse hairs. Ambulatory legs widened and quite strongly compressed; second pair a little longer than the others; fourth pair overreaching the carpus of the preceding pairs; dactyls short, terminating in slender, curved, corneous tips. Abdomen in the male widest at the second joint; the large, compound segment has the margin at first convex and then slightly concave; the two following segments broader than long; terminal segment subrectangular but distally rounded; the last two segments may be partly coalesced.

Length, $4.7 \mathrm{~mm}$; breadth, $4.2 \mathrm{~mm}$.

False Bay, San Diego County, Calif., from the mantle of Mya arenaria L. and Puget Sound from the mantle of Cardita borealis Con rad (Miss Rathbun). San Diego!

Described from specimens from Puget Sound kindly sent me by Miss Rathbun. A specimen I collected at San Diego was found on the beach free from any host. 


\section{Subfamily ASTHENOGNATHINÆ.}

Exterual maxillipeds with both ischium and merus well developed. Last pair of ambulatory legs not rudimentary or abortive.

\section{Genus Opisthopus Rathbun.}

"Carapace usually firm and unyielding; smooth, subquadrilateral, regions not defined; lateral margius regularly arcuated. Epistome very short. Abdomen seven-jointed, in the male not covering the sternum between the coxæ of the last pair of ambulatory legs. Eye-peduncles short. Antenni small, sicuated at the inner orbital hiatus; basal joint small. Antenuulr obliquely plicated. External maxillipeds with the ischium well dereloped, the merus broad, the palpus three-jointed, the ultimate joint articulated on the inner side of the penultimate. Chelipeds moderate; ambulatory legs subequal in leugth, joinis flattened."

Type.-O. transversus RathвоN.

\section{Opisthopus transversus Rath.}

Opisthopus transversus RathBor M., Proc. U. S. Nat. Mus., Vol. XVI, 1893, p. 252.

Carapace thin, convex, transverse. Front deflexed, with a slight median sulcus. Ischium of the maxillipeds broad; merus as broad as long, with the antero-external angle broadly rounded; palp large, last joint " narrow, inversely spatulate, overreaching the penultimate joint. Chelipeds rather stout; merus broad, trihedral; palm a little longer than the fingers, thick, slightly compressed, margins rounded, lower margin convex." Ambulatory legs similar; second pair longest; fourth pair shortest; dactyls small, curved, little more than half the length of the propodi.

Length of Carapace.

Width of Carapace.

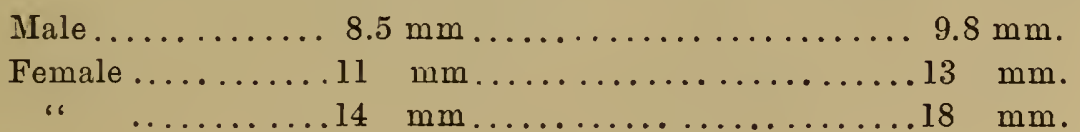

Monterey and Point Loma (Miss Rathbun). One male from the shell of Lucapina crenulata Sowerby from Monterey. San Diego! 


\section{Subtribe OXYSTOMATA, or LEUCO- SOIDEA.}

Carapace very variable in form. Epistome rudimentary. Buccal area narrowed in front. Antennules longitudinal or oblique. The afferent branchial channels enter either behind the pterygostomian regions and in front of the chelipeds, or at the antero-lateral angles of the palate. Verges of the male in the sternum or the coxæ.

\section{Family CALAPPID $Æ$.}

Afferent branchial channels opening behind the pterygostomian regions and in front of the chelipeds. The palp of the external maxillipeds is not entirely concealed by the merus. Verges of the male on the coxæ of the last pair of legs.

\section{Genus Platymera Milne-Edwards.}

Carapace convex, transversely elliptical, with a strong spine at the lateral angles; antero-lateral margins arcuated and dentate; postero-lateral margins not produced into lateral expansions. Front narrow. Orbits oval, deep, of moderate size, and furnished with a prominent fissure in the lower margin. The basal antennal joint is situated in the wide inner orbital hiatus and does not reach the front; flagellum small. Buccal cavity comparatively in front and more or less completely divided by a median ridge. The external maxillipeds do not completely cover the anterior portion of the buccal area; merus subequal to the ischium and excavated at the antero-internal angle; palp situated at the antero-internal angle of the merus and not completely covered over; the epipodite forms a broad, semilunar plate which covers the opening of the afferent branchial channels. Chelipeds large and, when folded, fitting closely to the body; merus trigonal; hands large, compressed, distally widened, surmounted by a laminate and dentate crest, and furnished with a longitudinal, granulated ridge near the lower side of the onter surface. Ambulatory legs slender, compressed, and furnished with long, styliform dactyls; first three pairs subequal in length, the fourth the shortest. Sternal plastron oval. The abdomen in the male is composed of five distinct joints, the third of which is furnished with a prominent, transverse posterior crest.

Type.-P. Gaudichaudii MiLne-EdwaRds. 


\section{Platymera Gaudichaudii Milne-Edwards.}

Platymerce Gaudichaudii Minne-Edwards, Hist. Nat. Crust., T. II, 1837, p. 10S. Edwards and Lucas, D'Orbigny's Voy. l'Amer. Mérid. VI, Part I, 1843, p. 28, Pl. XIII, fig. 1. FAXov, Mem. Mus. Comp. Zool. Harvard Coll., Vol. XviII, 1895, p. 32. Rathbux M., Proc. U. S. Nat. Mus., Vol. XXI, 1898, p. 610.

Platymera californiensis Rathbox M., Proc. U. S. Nat. Mus., Vol. XVI, 1893, p. 253.

Carapace strongly convex, evenly granulated and furuished with several small, depressed tubercles. The anterior margin of the front is truncated and strongly concave when seen from in front. Postorbital tooth very small. Antero-lateral margin regularly arcuated and armed with about fifteen small teeth separated by concave interspaces. Lateral spine large, straight, subcylindrical. Maxillipeds granulated; ischium dentated on the inner margin; merus very deeply excirvated at the antero-internal angle. Merus of the chelipeds armed with a spine at the infero-distal angle, above which is a small tooth; carpus with some small tubercles on the outer surface; hands also furnished with several small tubercles on the outer surface; the ridge on the lower portion of the outer surface is very large and bears a small tooth near the proximal end; the superior crest is more or less hairy and armed with six teeth; a granulated ridge on the lower side of the hand; pollex short, subtriangular, flattened, depressed; the outer margin of the finger is prominent, granulated, and when closed, is at right angles to the palm. Upper margins of the ambulatory legs granulated, either the first or the second pair may be the longer.

Length of carapace, $41 \mathrm{~mm}$.; breadth between tips of lateral spines, 79 $\mathrm{mm}$.; length of lateral spine, $12 \mathrm{~mm}$.

Described from a specimen received from Miss Rathbun.

Chili; Panama to lat. $37^{\circ} 0^{\prime} 30^{\prime \prime}$ N., lon. $122^{\circ} 33^{\prime} 30^{\prime \prime}$ W. Depth, 29 to 204 fathoms.

\section{Family LEUCOSIID $Æ$.}

Afferent branchial channels opening at the antero-lateral angles of the palate. Palp of the external maxillipeds entirely concealed beneath the merus. Verges of the male on the sternum.

\section{Genus Randallia Stimpson.}

Carapace subhemispherical; evenly rounded at the sides, with two lobes or teeth on the posterior margin. Front narrow, very short, with a concave anterior margin. Eyes small, and located in small, circular orbits 
which are provided with two or three marginal fissures. Antennules obliquely plicated, the laminiform basal joint capable of closing over and concealing the following joints. Antennæ minute, with the basal joint comparatively large. Merus of the maxillipeds subtriangular, shorter than the ischium, reaching nearly as far forward as the front; exognath broad and nearly as long as the endognath. Chelipeds rather long; merus subcylindrical; hand narrow; fingers acute and somewhat compressed. Ambulatory legs of moderate length, the joints not dilated; dactyls styliform. The base of the abdomen in the male covers the last thoracic sternum; distal portion narrowed.

Type.-R. ornata (RANDALL).

\section{Randallia ornata (Randall).}

Ilia ornata RANDAll, Journ. Acad. Nat. Sci. Phila., Vol. VIII, 1839, p. 129. Guiaia ornata Gibbes, Proc. Am. Ass. Adv. Sci., 1850, p. 186.

Randallia ornata Strmpson, Proc. Bost. Soc. Nat. Hist., Vol. VI, 1857, p. 85; Journ. Bost. Soc. Nat. Hist., Vol. VI, 1857, p. 471, Pl. XIX, tig. 3; Ann. N. Y. Lyc. Nat. Hist., Vol. VII, 1860, p. 69 . Rathbus M., Proc. U.S. Nat. Mus., Vol. XXI, 1898, p. 613.

Carapace nearly smooth, but furnished anteriorì with a few scattered granules and a few larger granulations at the sides. A granulated intumescence on the hepatic area and a blunt, granulated projection on the pterygostomian regions. A small tubercle on the posterior portion of the branchial region. Posterior margin of the carapace elevated, granulated, and furnished with two pointed tubercles. Maxillipeds granulated, the exognath considerably narrower than the endognath. Merus of the chelipeds subcylindrical, pustulate; carpus granulated; hand long, palm inflated, and granulated on the upper margin; fingers slender, sulcate, generally longer than the palm, and finely dentate. Ambulatory legs subcylindrical; propodi with acute, grauulated upper margins; dactyls longer than the propodi; those of the first pairs compressed; those of the last depressed. Abdomen of the male narrowly triangular, acute, five-jointed, the third joint longer than the two following ones. Penultimate abdominal segment in the female large, smooth, convex, covering nearly the entire sternum; last joint small, oblong, distally rounded. The sternal surface in the female is deeply excavated and bounded by a prominent rim, against which the large segment of the abdomen closes. The inner side of this segment is hollowed out, thus forming a capacious chamber for holding the ova. At the anterior margin of the rim is a deeply concave notch which receives the small, terminal segment of the abdomen.

The carapace is of a light color marbled with reddish patches which are larger in front.

Length and breadth of a specimen each $48 \mathrm{~mm}$. 
Mendocino County, Calif.! Santa Barbara! Santa Catalina Island! San Diego! Magdalena Bay and off Abreojos Point, Lower California (Rathbun).

\section{Randallia bulligera Rathbun.}

Randallia bulligera Rathbun M., Proc. U. S. Nat. Mus., Vol. XXI, 1898, p. 614, Pl. XiLIV, fig. 6.

A small species. Carapace a little longer than wide and covered with distinct, smooth, bead-like tubercles; a sulcus behind the tumid hepatic regions, and in front and at the sides of the intestinal area; posterior margin of the carapace with two, pointed, granulated tubercles; a granulated tubercle on the posterior end of the branchial area, and a single. tubercle on the intestinal region; frontal margin concave. Pterygostomian regions with a longitudinal, tuberculated prominence. Antero-lateral angles of the buccal area with three prominent lobes which project in front of the maxillipeds. Sternum and abdomen tuberculated. 'Maxillipeds with prominent tubercles. Merus of the chelipeds cylindrical, tuberculated like the carapace; carpus and hand granulated. Ambulatory legs granulated; dactyls slender, longer than the propodi.

Coloration much as in ornata.

Magdalena Bay, Lower California (Miss Rathbun); off San Diego, 30 fathoms!

Easily distinguished from ornata by the numerous bead-like tubercles on the carapace and the lobes at the anterior end of the buccal area.

\section{Tribe MACROURA.}

Body generally elongated, though sometimes broad. Abdomen generally large and exceeding the carapace in length, the sixth segment usually bearing well developed pleopods which, with the telson, form a strong tail-fin. Eye-peduncles not lodged in weil defined orbits. Antennules generally elongated and not lodged in fossettes. Antennæ usually furnished with a scale (exopod) attached to the second joint. The external maxillipeds are typically pediform. Any or none of the pereopods may be chelate. The vulvæ of the female are in the coxæ of the third pair of legs. 
Kex to the Sobdivisions of the Macroura.

Abdomen asymmetrical Paguridea. Abdomen symmetrical.

Exoskeleton calcareous; pereopods mostly six-jointed.

None of the three anterior pairs of pereopods chelate... Loricata. All of the three anterior pairs of pereopods chelate... Homaridea.

First pair, or first two pairs of pereopods chelate; third pair never chelate.

Last pair of pereopods reduced, slender, folded.

Thoracic sternum broad.............. Galatheidea.

Thoracic sternum linear................. Hippidea.

Last pair of pereopods not greatly reduced.....Thalassinidea. Exoskeleton generally corneous; pereopods seven-jointed.

Antemnal scale large. Swimming forms with generally laterally compressed bodies.

Third pair of pereopods chelate............... Penceidea. Third pair of pereopods not chelate................ Caridea.

\section{Subtribe HIPPIDEA.}

Carapace ovate or subquadrate, comparatively smooth, the regions not well defined. Interantenuulary region broad. Eyes small. Antennules generally well developed, with one flagellum elongate, the other short or absent. Antennæ with a large five-jointed peduncle, with or without an acicle. Maxillipeds more or less operculiform. Dactyls of the ambulatory legs flattened; fifth pair of legs slender and filiform. Thoracic sternum linear. Abdomen partially extended; telson large; penultimate abdominal joint with a pair of biramous lamellate appendages, which, however, do not form a caudal til in connection with the telson. The males have no abdominal appendages, except the last pair. Pterygostomian regions free from the epistome.

\section{Family HIPPID $A$.}

Antennal acicle small or absent. Maxillipeds operculiform, the merus broad; exognath wanting. First pair of legs not subchelate. Telson elongated, lanceolate.

\section{Genus Hippa Fabr.}

Antennules of moderate length. Antennal flagellum very long, stout, multiarticulate and strongly ciliated. Maxillipeds with the ischium very small and the merus very large; the terminal joint narrow and compressed. Dactyls of the first parr of legs oval and lamellate.

Type.-H. emerita L. 


\section{Hippa analoga St.}

Hippa emerita De Saussure, Rev. et Mag. de Zool., T. V, 1S53, p. 367. Ortiaxi, Zool. Jahrb. Abth. f. Syst., Bd. IX, 1S96, p. 232.

Hippa talpoidea DarA., Proc. Acad. Nat. Sci. Phila., 1S54, p. 175.

Hippa analoga Strupsox, Proc. Bost. Soc. Nat. Hist., Vol. VI, 1857, p. S5;

Journ. Bost. Soc. Nat. Hist., Vol. VI, 1S57, p. 4 S6. Mrers, Journ.

Linn. Soc. London, (Zool.) Vol. XIV, 1S79, p. 324, Pl. V, fig. 10.

Ortuavs, Zool. Jahrb. Abth. f. Syst., Bd. VI, 1892, p. 537, P1. XXVI, fig. 1.

Carapace oblong-oval, very convex, and marked with irregular, trans. verse, crenulated lines which become much less marked towards the sides and posterior end. An impressed, nearly straight, transverse line behind the front, and an impressed line which is concave in front on the median region. Median lobe of the front subtrianguiar but rounded at the tip; the lateral lobes are triangular and acute and project farther forward than the median lobe from which they are separated by round, smooth sinuses. Antero-lateral margins serrated. Eye-stalks long and very slender. Second joint of the antennal peduncle furnished with three spines of which the median is the largest and upturued at the tip; lowest spine smallest; superior spine more or less upturned; flagellum very long, curved and bent back under the body. Merus of the maxillipeds with the lobe at the antero-internal angle rounded. First pair of thoracic legs with a strong spine at the supero-distal angle of the carpus and at the infero-distal, angle of the propodus; dactyl ovate. Dactyls of the second and third pairs falcate, very broad at the base, and subacute at the tip. Telson narrowly triangular, acute; outer surface convex, smooth, glossy; margins raised and furnished with two rows cf hairs, the inner row lying on the surface.

Length of carapace, $29 \mathrm{~mm}$.; width, $23 \mathrm{~mm}$.; length of telson, $19 \mathrm{~mm}$.; width of telson, $9.5 \mathrm{~mm}$; length of abdomen when extended, $37 \mathrm{~mm}$. The ratio of the length of the carapace to its breadth is quite variable.

Oregon to Panama on sandy beaches.

\section{Family ALBUNEIDÆ.}

Anterior legs more or less perfectly chelate. The maxillipeds are subpediform or oniy moderately expanded, and furnished with an exognath. Telson not elongated, generally ovate and lamellate.

\section{Genus Blepharipoda Randall.}

Eye-pednncles very slender, elongated, cylindrical, and articulated in the middle. Antennules and antennær rather long, with multiarticulate flagella. Antennæ devoid of an acicle. Merus of the maxillipeds narrow, similar to the carpus; carpus not produced at its antero-external angle.

Type.-B. occidentalis RAydall. 


\section{Blepharipoda occidentalis Randall.}

Blepharipoda occidentalis Randall, Journ. Acad. Nat. Sci. Phila., Vol. VIII, 1839, p. 131, Pl. VI. Gibbes, Proc. Am. Ass. Adv. Sci., 1850, p. 187. Dana, Crust. U.S. Expl. Expd., Part I, 1852, p. 406 . Stimpson, Journ. Bost. Soc. Nat. Hist., Vol. VI, 1857, p. 486; Proc. Acad. Nat. Sci. Phila., 1858, p. 230. Miers, Jouru. Linn. Soc. London, Vol. XIV, 1879, p. 334. Ortmann, Zool. Jahrb. Abth. f. Syst., B'd. IX, 1896, p. 222.

Carapace oblong, scabrous in front, but smooth and punctate behind. The middle of the carapace is elevated, forming a longitudinal ridge which ends anteriorly in a spine immediately behind the transverse postfrontal impression. A transverse impression behind the median region and an oblique one on either side terminating at the last lateral spine. Front with a median spine separated by a rounded sinus from the more prominent triangular spine-tipped, lateral teeth. Antero-lateral margin with three large spines and a smaller fourth spine some distance further back. The last joint of the eye-peduncles is but little longer than the preceding one. Antenuules with the upper flagellum long (over one-haif the length of the carapace) and strongly ciliated; lower flagellum scarcely as long as the peduncle. Peduncle of the antennæ long (nearly one-half the length of the carapace), the last two joints cylindrical and ciliated on the outer surface; flagellum curled, strongly ciliated on one side, and somewhat shorter than the peduncle. Ischium of the maxillipeds dentate on the inner margin and produced at the antero-internal angle; exognath reaching considerably beyond the midale of the merus. Chelipeds strong; merus short, stout, with one or more spines on the lower side; carpus scabrous externally, with the supero-distal angle produced into a large, compressed, triangular, spine-tipped tooth; at the base of this tooth the upper margin is armed with a variable number of spines; and there may be several small spines on the anterior edge; hand flattened, the outer surface scabrous and furnished with two spines, one near the base, the other behind the gap between the fingers; a spine near the middle of the lower margin, in front of which there may be several smaller ones; pollex broad, triangular, much compressed, with the inner margin armed with a variable number of spines; dactyl rather slender, curved, and spiny on the outer edge. The ambulatory legs have the anterior margins of the carpi spinulous and the antero-distal angles produced; dactyls subfalciform, but varying greatly in shape in the different pairs. The slender last. pair of legs ends in a small, well developed chela. The lateral expansions of the fifth abdominal segment are subacute. The inner ramus of the uropods is narrower than the outer and articulated near the middle of the side of the peduncle, the outer one joined to the tip. Telson short, 
suborbicular, thick and convex in the middle, but with the sides laminate.

Length of carapace, $46.5 \mathrm{~mm}$; breadth of carapace, $35 \mathrm{~mm}$.

Length of carapace, $47 \mathrm{~mm}$; breadth of carapace, $36 \mathrm{~mm}$.

San Diego (Randall)! Monterey (Miers); Santa Monica, Calif.! Estero Bay! San Quentin Bay, Lower California!

\section{Genus Lepidopa Stimpson.}

Eye-peduncles lamellate, compressed, almost squamiform; corner rudimentary. Antenumles long. Antenur with a very small accessory joint; flagellum very short. Maxillipeds with the fourth joint produced at the antero-external angle into a lobe which reaches to or beyond the distal extremity of the fifth (penultimate) joint.

Type.-L. scutellata (FABR.)

\section{Lepidopa myops St.}

Lepidops myops Stimpson, Ann. N. Y. Lyc. Nat. Hist., Vol. VII, 1860, p. 241. Miers, Journ. Linn. Soc. (Zool.) London, Vol. XIV, 1879, p. 333, Pl. XIV, fig. 16.

Lepidopc myops Ortmann, Zool. Jahrb. Abth. f. Syst., Bd. IX, 1896, p. 226.

Carapace oblong, with an obtuse median ridge, and marked with transverse grooves. Front trilobed, the median lobe rounded and shorter than the lateral lobes, which are acute. A spine at the antero-lateral angles. Posterior margin of the carapace deepiy concave in the center. Ocular peduncles oblong, broadly rounded in front, the cornea when present minute and located on the margin near the antero-lateral angle. Antennules ciliated and over twice the length of the carapace. Antennæe shorter than the carapace; a thin lamina on the inner side of the basal joint; acicle minute; flaelglum scarcely as long as the peduncle. Chelipeds stout; hand high, and strongly compressed; pollex very short and curved; finger rather slender, curved, and, when closed, lying nearly at right angles to the long axis of the hand. The dactyls are compressed, falcate, dissimilar. The second, third, and fourth abdominal segments are furnished with wide, wing-like expansions which diminish in length and breadth posteriorly. Telson about as wide as long and rounded at the sides and apex.

Length of carapace, $15 \mathrm{~mm}$; breadth, $17 \mathrm{~mm}$.

Cape St. Lucas (Stimpson); Lower California! San Diego (five specimens)!

The small teeth on the median frontal lobe mentioned by Stimpson are present on only a part of the specimens I have seen. 


\section{Subtribe GALATHEIDEA.}

Rostrum present. Body flattened, the carapace divided by a lateral (anomoural) line. Abdomen flattened, the sides of the segments generally laterally produced. Tail-fin well developed. Pterygostomian regions free from the epistome. External antennæ four-jointed, the second and third joints fused; acicle small or absent. First pair of pereopods chelate; the last pair chelate, rudimentary, and folded in the branchial chamber.

\section{Legion PORCELLANINEA.}

Carapace broad, smooth. Antennules concealed. Antennæ long and generally furnished with a scale. Ischium of the maxillipeds broad and flattened; merus broad, with a prominent inuer lobe. Chelipeds large, often flattened; first three pairs of ambulatory legs well developed; last pair slender, inflexed. Abdomen loosely bent under the trunk.

These crabs in the form of the carapace, the bend of the abdomen, and in their flattened maxillipeds resemble the true Brachyura; but these resemblances are not indicative of true affinity for both groups had, in all probability, an independent origin from Macrouran ancestors.

\section{Genus Petrolisthes St.}

Carapace subovate, depressed, generally longer than wide. Front triangular, entire or dentate, usually depressed, the margins more or less undulated. Eyes of rather large size. First basal joint of the antennæ very short, not reaching the upper margin of the carapace; the second joint is flattened and more or less cristate; flagellum long. Chelipeds broad and flattened; the carpus elongated, with or without teeth on the inner margin. The dactyls of the ambulatory legs are short and stout and terminate in a siugle claw.

Type.-P. violaceus (GUERIN). 


\section{Petrolisthes cinctipes (Randall).}

Porcellana cinctipes Raxdall, Journ. Acad. Nat. Sci. Phila., Vol. VIII, 1S39, p. 136.

Porcellana rupicola Stimpsox, Proc. Bost. Soc. Nat. Hist., Vol. VI, 185`, p. S5; Journ. Bost. Soc. Nat. Hist., Vol. VI, 1S57, p. 480, Pl. XIX, fig. 2. Bate in Lord's Nat. in Vancoiver's Is., Vol. II, 1S66, p. 276. Petrolisthes rupicolus Strmpsox, Proc. Acad. Nat. Sci. Phila., 1S58, p. 227. Lockingtox, Ann. Nat. Hist. (5), Vol. II, 1878, p. 396. Newcombe, Bull. Nat. Hist. Brit. Col., 1593, p, 30.

Petrolisthes cinctipes Ortuarr, Zool. Jahrb. Abth. f. Syst., Bd. X, 1897, p. 27 S.

Carapace longer than wide, and quite distinctly areolated; the auterior portion is roughened by minute prominences and the branchial regions are transversely finely striated. Front triangular, depressed, blunt, transversely concave above, with a rounded notch on either side of the base next to the orbit. Antero-lateral margin marked by a raised line. Ocular peduncles somewhat flattened; superior margin of the orbit slightiy concare. Antennal peduncle granulated; the flagellum may exceed one and one-half times the length of the carapace, and is furnisbed with a few setæ which are longer than the width of the joints. Ischium of the maxillipeds finely rugose, the distal margin transverse and broadly rounded; the outer border is prolonged into a lobe; the lobe on the inner side of the merus is prominent and distally rounded. Chelipeds granulated above; a small tooth at the antero-distal angle of the merus; carpus slightly tapering towards the distal end; no teeth on the anterior margin but the inner angle is prominent and evenly rounded; the posterior surface of the carpus is rugose, the upper edges of the projecting rugæ formiug a rough ridge along the posterior margin which terminates distally in a tooth; hands strongly flattened, outer edge acute, nearly straight along the middle; tips of the fingers curved. Ambulatory legs more or less rugose, the merus expanded and nude; propodi hairy and furnished with a few short spinules near the distal end of the posterior margin; dactyls short, hairy, curved, acute, and generally furnished with a few minute spines below. The posterior pair of sutures in the telson is oblique.

Length, $20.5 \mathrm{~mm}$; breadth, $19.75 \mathrm{~mm}$.

Vancouver's Island (Bate, Newcombe); Kumboldt County, Calif.! San Francisco Bay! Monterey! Santa Barbara! Santa Catalina Island! San Diego! San Miguel Island; west coast of Lower California and Gulf of California (Lockington). 
This is one of the most common of our California crabs and is generally found under rocks at low tide. According to Ortmann (l.c.) "Die in Philadelphia aufbewahrten Originale Randall's zeigen, dass cinctipes dieselbe Art ist wie rupicola. Der von Randall angegebene fundort 'Sandwich-Ins.' beruht offenbar auf der unter seinem Material vorgekommenen Verwechslung der Localitäten." I am unable to follow Ortmann in uniting eriomerus St. with this species. The two forms occur together on a great part of the California coast and keep perfectly distinct.

\section{Petrolisthes_eriomerus St. Pl.I. f.15}

Petrolisthes eriomerus Strmpson, Ann. N. Y. Lyc. Nat. Hist., Vol. X, p.

119. Lockington, Ann. Nat. Hist. (5), Vol. II, 1878, p. 397.

Closely allied to cinctipes. Carapace smooth and punctate, though there are often minute prominences, especially anteriorly, which are not so marked as in the preceding species. Front not so strongly deflexed as in cinctipes. The antennæ may be over twice the length of the carapace and are devoid of setæ. Distal extremity of the ischium of the maxillipeds more or less truncated. Chelipeds longer and smoother than in cinctipes; the carpus is narrower and has the sides parallel; the antero-interual angle is much less prominent and the ridge on the posterior margin rougher. The merus joints of the ambulatory legs are hairy and less dilated than in the preceding species. The last pair of sutures on the telson is transverse or nearly so.

Humboldt County, Calif., to San Francisco Bay! Point Mendocino (Stimpson)! I have collected numerous species at the latter, or type locality. Cinctipes is also abundant in the same place.

\section{Genus Pachycheles Stimpson.}

Carapace round-ovate, or suborbicular, and not longer than wide, the posterior portion of the subbranchial region subquadrate and separated from the larger anterior portion by a membranons interval. Front but little produced, subacute, edentulous. First joint of the antennal peduncle 
produced and joined to the margin of the carapace; second joint at some distance from the orbit. Chelipeds thick and roughened; carpus short. Dactyls short and terminating in a single claw.

Type.-P. grossimanus (GoERIX).

\section{Pachycheles rudis St.}

Pachycheles rudis Stimpsox, Ann. N. Y. Lyc. Nat. Hist., Vol. VII, 1862, p. 76; Proc. Acad. Nat. Sci. Phila., 185s, p. 228. Lockrngton, Ann. Nat. Hist. (5), Vol. II, 1878, p. 404. Newcombe, Bull. Nat. Hist. Soc. Brit. Col., 1893, p. 30. Ortuan, Zool. Jahrỉ. Abth. f. Syst., Bd. X, 1897, p. 294.

Carapace nearly smooth, quite strongly convex longitudinally, and finely striated on the branchial regions. Front short, deflexed, entire, and hairy above. Sides of the carapace evenly rounded and marked by a raised line. Sinus in the posterior margin deep and subacute in the middle. Superior margin of the orbit concave but not raised; outer angle of the orbit acute. Distal end of the ischium of the maxillipeds evenly rounded; inuer lobe of the merus prominent, rounded. Chelipeds unequal, with a rough, irregular, grauulated, or tuberculated upper surface, which is more or less hairy; merus with an anterior tooth; carpus short, about as broad as long, the anterior margin laminate, angular, and often furnished with one or more teeth; the posterior margin is convex and the upper surface bears two more or less evident longitudinal, granulated ridges; hands broad, subtriangular, very nueven above, and furnished with a rounded protuberance near the middle; the lower surface is glossy and very finely granuiated at the center, but the granules become larger towards the margins; fingers stout, granulated. Ambulatory legs stout and more or less rugose; dactyls short, curved, and furnished with two or three spines below; posterior margins of the propodi with a few spines.

Length, $14.5 \mathrm{~mm}$; breadth, $15.25 \mathrm{~mm}$.

British Columbia (Newcombe); Humboldt County, Calif., to San Francisco Bay! Monterey! Santa Rosa Is.! Santa Catalina Is.! Found under rocks at low tide. Lockington states that he found young specimens of this species in a bottle of material, without label, from Lower California. 


\section{Pachycheles pubescens, sp. nov.}

Carapace suborbiculate, not so convex longitudinally as in rudis, and more or less distinctly areolated in front, where it is marked by small, transverse punctures. Branchial regions transversely striated. Sinus of the posterior margin of the carapace subacute and not nearly so deep as in the preceding species. Front entire moderately deflexed, somewhat produced and rounded in the center. The membranous interval separating the parts of the subbranchial region is nearly vertical. Eyos large. Antenual peduncle compressed. Superior orbital margin concave; postorbital tooth acute. The ischium of the maxillipeds is finely transversely rugose and the distal margin is more or less truncated. Upper surface of the chelipeds not rugose or tuberculated, but coarsely granulated and setose; granulations large, smooth, shining, generally transverse, those on the hand larger, becoming more acute towards the outer side, where they give rise to a denticulated margin; a tooth on the anterior margin of the merus; carpus generally a little wider than long, the anterior margin laminate and cut into three or four teeth armed with secondary denticles, which are most numerous on the proximal tooth; hand similar in shape to that of rudis; fingers stout, the inner margins hairy. Legs stout, setose. Propodi and dactyls spinulous below.

Length of carapace, $15 \mathrm{~mm}$.; width, $15 \mathrm{~mm}$.; length of carpus, $11.5 \mathrm{~mm}$.; width, $11.5 \mathrm{~mm}$; l length of hand, $22 \mathrm{~mm}$; width, $13 \mathrm{~mm}$.

Drake's Bay, Calif.! Farallon Islands! Humboldt County, Calif.!

This species differs from Pachycheles setimanus (Lockington), the types of which I have examined, in its somewhat narrower carapace, more prominent front and broader pollex.

\section{Collection of the University of California.}

\section{Legion GALATHEINEA.}

Carapace elongated, generally rugose, and quite distinctly areolated; rostrum prominent, acute. Ocular peduncles short and stout, and lodged in incomplete orbits. Antennules not lodged in fossettes. Antennæ with the second and third joints often coalesced; flagellum long. Maxillipeds subpediform, the ischium and merus narrow. Chelipeds often slender and elongated. Fifth ambulatory legs feeble and inflexed. Abdomen broad and bent under the body; in the female the second to fifth segments 
generally bear appendages; in the male there are often sexual appendages on the first two segments, and the appendages on the three following segments may be well developed or rudimentary; the last pair of appendages is always well developed and forms, with the telson, a strong tail-fin.

\section{Genus Munida Leach.}

Carapace rugose, generally spinous, the cardiac area distinctly defined; the infero-lateral regions are not swollen ont and are separated from the dorsal surface by a well defined margin. Rostrum slender and styliform, with a supraorbital spine on either side of the base. Ocular peduncles free; eyes normal. Chelipeds and ambulatory legs elongated and slender. One or more of the abdominal segments usually furnished with a series of spinules on the anterior dorsal margin.

T'ype.-M. rugosa (FABR.).

This genus is represented off the coast of California by a species Munida (Grimothea) gregaria, the Galathea gregaria of Fabricius, which still appears to be of uncertain systematic position. Miers considers it the young of Munida subrugosa, while Henderson thinks it doubtful that such is the case. ${ }^{1}$ Owen ${ }^{2}$ reports this species from "off San Francisco."

\section{Genus Pleuroncodes St.}

Near Munida. Carapace rugose, with the infero-lateral margins swollen out so that the sutures (anomoural lines) are visible from above. Rostrum styliform, with a supraorbital tooth on either side of the base. Ocular peduncles free; eyes large, normal. Insertion of the antenni not concealed beneath the antero-lateral angles of the carapace. Merus of the maxillipeds unarmed, the penultimate joint slightly dilated.

Type.-P. monodon (MILive-Edwards).

1 See Miers' Catalogue of New Zealand Crustacea, p. 168 ; Henderson, Challenger Reports Vol. XXVII, p. 124; and Milne-Edwards and Bouvier, Ann. Sci. Nat. (7), T. XVI, 1894 pp. 256 and 314.

2 Zöology of Beechy's Voyage, Crustacea, 1839, p. 87. 


\section{Pleuroncodes planipes $S t$.}

Pleuroncodes planipes Stimpson, Ann. N. Y. Lyc. Nat. Hist., Vol. VII, 1860, p. 245. A. Milne-Edwards, and Bodvier, Ann. Sci. Nat. (7), T. XVI, 1894, pp. 248 and 245.

Closely allied to $P$. monodon from the coast of Chili. Carapace crossed by setose striæ but, with the exception of a few spinules behind the supraorbital teeth, devoid of spines. Rostrum long, very slender, scabrous above, and continued back upon the carapace as a carina; supraorbital teeth spine-like. A spine at the rounded antero-lateral angle of the carapace, behind which there are a few spines on the margin. Ocular peduncles not reaching the tip of the rostrum; eyes large. Maxillipeds with a small spine at the antero-internal angle of the ischium; penultimate joint moderately dilated. Chelipeds long, slender, and spinous; merus slender, trigonous, spinulous, especially on the edges, and generally exceeding the tip of the rostrum; carpus spinous; hand long, narrow, spinulous, with the upper and lower margins parallel; fingers slender, straight, longer than the palm, the tips curved. Ambulatory legs scabrous, ciliated, with the penultimate joints flattened. Abdomen devoid of spines.

"This species," says Stimpson, "lives in the open ocean, and is sometimes found in vast quantities in the Pacific off the American Coast. It was taken by $\mathrm{Mr}^{2}$. Grayson in N. lat. 24\%, W. Ion. $130^{\circ}$. In March, 1859, it was thrown ashore in considerable numbers at Monterey, California."

Ninety miles southwest of San Francisco, Calif.! 150 miles southwest of Cape St. Lucas, Lower California, numerous specimens!

\section{Subtribe PAGURIDEA.}

Carapace with a lateral (anomoural) line. Pterygostomian regions free from the epistome. External antennæ with a five-jointed peduncle and, generally, with an acute, movable acicle. First pair of pereopods large, chelate, often unequal; last pair small and generally more or less chelate. Abdomen asymmetrical, the lower and often the upper side membranous; the appendages generally reduced or absent, and commonly occurring only on one side. 


\section{Legion LITH ODINEA.}

Carapace broad, often resembling that of the Brachyura. Rostrum generally well developed. Third ambulatory legs subequal to the preceding pair; last pair feeble, chelate, and folded in the branchial chamber. Sternum wide. Abdomen bent under the thorax; in the male it is devoid of appendages, but in the female the first segment miy bear a small pair, and each of the four following segments often has an appendage only on the left side.

\section{Key to the Genera of Lithodinea.}

Carapace smooth and produced laterally into two wings, which conceal the ambulatory legs............................ Carapace not so produced.

Carapace devoid of spines or tubercles on the upper surface.

Carapace much flattened, hairy............... Hapalogaster.

Carapace not much flattened; acicle curved........Edignathus.

Carapace not much flattened; acicle straight........ Dermaturus.

Carapace with spines or tubercles above.

Carapace with deep pits above...............Phyllolithodes.

Carapace not deeply pitted.

Abdomen membranous. Carapace spiny.... Accuntholithodes. Abdomen furnished with calcareous plates.

Carapace tuberculated .............. Lopholithodes.

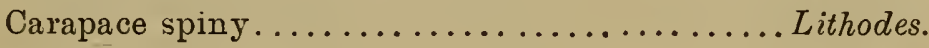

\section{Genus Hapalogaster Brandt.}

Carapace flattened and marked with chitinous, uncalcified lines; lateral margin with teeth or spines. Last joints of the external maxillipeds dilated. Chelipeds depressed, very unequal; hands more or less trigonal, moving horizontally. Ambulatory legs depressed. Abdomen soft, loosely inflexed, the basal segment with a transverse, calcareous plate on either side.

Type.-H. Mertensii BraxdT.

\section{Hapalogaster cavicauda St.}

Hapalogaster cavicauda Strupsox, Ann. N. Y. Lyc. Nat. Hist., Vol. VII, 1860, p. 81, Pl. I, fig. 7; Proc. Acad. Nat. Sci. Phila., 1858, p. 232. Schalfeew, Mélan. biol., Tome XIII, p. 326, du Bull. Acad. imp. sci. St. Petersb., Tome XXXV, p. 332. BoAS, Vid. Selsk. Skr., 6 Rœkke, Natur. og Math., Afd. 1, 2, 1894, p. 194, P1. VI, fig. 200. Bouvier, Ann. Sci. Nat. (7), Tome XVIII, 1894, p. 166, Pl. XI, fig. 2, and PI. XII, figs. 1, 15, 27 and 29; Ibid. (8), Tome I, 1896, p. 2, et seq. 
Body and legs much flattened and densely covered with short hair. Carapace subcordate, nearly smooth, but roughened or granulated at the insertions of the hairs. Front short, acute, narrowly triangular. Postorbital tooth large, acute, and extending nearly as far forward as the front. Superior orbital margin concave and furnished with a small, acute tooth which is separated from the postorbital by a deep fissure. The portion of the antero-lateral margin in front of the cervical groove is convex, sublaminate, edentate, and separated from the portion behind the groove by an incision; two marginal teeth at the origin of the sutures. Ocular peduncles short, hairy, and swollen at the base, where they are furnished with a small, smooth tubercle. Antennro about as long as the carapace; acicle ovate, acute, very thin, more or less transparent, and margined by hairs on both sides; a smooth, slender spine joined beneath, and reaching nearly to the tip of the acicle. Second joint of the palp of the maxillipeds with a rounded inner lobe; last joint rounded distally and somewhat flattened. Chelipeds flattened, not tuberculated, anterior margin of the merus produced and cut into two teeth; carpus produced into a tooth at the postero-distal angle and bearing a single spine at the proximal end of the anterior margin; larger hand with one or more small, calcareous tubercles on inner face behind the articulation of the dactyl; inner margin of the smaller hand produced into a rounded lobe behind the base of the dactyl; the fingers of the smaller hand are excavated within, the edges corneous and armed with small, calcareous denticles. Ambulatory legs much flattened and very hairy, the anterior margins deeply incised, forming four or five closely approximated teeth on each of the larger joints; postero-distal angle of the carpi produced into a tooth or lobe which is very prominent on the third pair; dactyls short, flattened, the curved, corneous tips turned obliquely to the plane of compression. The abdomen is broad and bent abruptly at about the third segment, the reflexed portion not so hairy as the upper side; the calcareous plates on the basal segment are wide and separated by a membranous interval in which there is no median plate. In the female the left side of the abdomen is coriaceous and segmentally incised.

Length of carapace from tip of rostrum, $17 \mathrm{~mm}$; breadth, $19 \mathrm{~mm}$; length of large hand, $28 \mathrm{~mm}$; length of small hand, $20 \mathrm{~mm}$.

Northern to southern California! Monterey (Stimpson)! Found under rocks at low tide. Common. 


\section{Hapalogaster Mertensii Brandt.}

Hapalogaster Mertensii BRAxd, Mélanges biologiques, Tome I, 1850, p. 58. Stimpsox, Journ. Bost. Soc. Nat. Hist, Vol. VI, 1857, p. 480. SchalfeEw, Mélang. biol., Tome XIII, 1892, p. 327, figs: 4 and $5 a$, du Bull. Acad. imp. sci. St. Petersb., Tome XXXV, 1892, p. 333. Newcombe, Bull. Nat. Hist. Soc. Brit. Col., 1893, p. 28. Bodvier, Ann. Sci. Nat. (8), Tome I, 1896, p. 4 et seq.

Carapace with scattered tufts of setro on the upper surface. Rostrum acuminate, longer than in cavicauda. A large, sharp spine at the outer orbital angle, and a smaller sharp spine on the superior orbital margin, separated from the last by an incision. No marginal spines in front of the cervical groove, but behind it there are five slender spines which decrease in size posteriorly. Merus of the large cheliped armed in front with a pair of large spines having a small spine on either side; carpus armed with several spines subserially arranged; hand narrow, with three rows of large spines on the outer surface and a row of smaller spines on the upper edge; in the smaller hand there are four spines on the outer border, three on the inner edge, a row of three spines on the upper surface near the inner side, and a single spine between this row and the outer edge near the gap between the fingers. Ambulatory legs armed with sharp spines on the anterior margin.

Described from five specimens in the National Museum from Kadiak, Alaska (No. 19471), collected by W. J. Fisher.

\section{Sitka (Brandt); Kadiak (Schalfeew)! British Columbia} (Bouvier); near Victoria (Newcombe).

\section{Hapalogaster Grebnitzkii Schalfeew.}

Hapalogaster Grebnitzkii Schalfeew, Mélang. biol., Tome XIII, 1892, p. 329, figs. $3 a$ and $3 b$, du Bull. Acad. imp. sci. St. Petersb., Tome XXXV, 1892, p. 335. Bouvier, Ann. Sci. nat. (8), Tome I, 1896, p. 4 et seq.

Closely allied to Mertensii. Carapace devoid of prominent tufts of setæ. Rostrum prominent, acuminate; a large spine at the outer orbital angle and a sharp spine on the superior orbital margin which is relatively larger than the corresponding spine in the preceding species. Margin of the carapace behind the cervical groove armed with five spines, which decrease in size posteriorly. Legs armed with setose spines. The merus of the large cheliped is similar to that of Mertensii, but the carpus has 
fewer spines above; hand shaped as in Mertensii, but having only two rows of spines on the outer surface and a row of small spines on the inner edge; there is a broad, smooth interval on the outer surface, which in Mertensii is armed with the median row of spines. The number and arrangement of the spines on the smaller hand is the same as in the preceding species, with the exception that there is no spine behind the gap between the fingers.

Described from numerous specimens in the National Museum from Humboldt Bay (No. 19443, Albatross collection); Behring Is., Kadiak Is. (Schalfeew).

\section{Genus Dermaturus Brandt.}

Carapace more or less lyrate, devoid of prominent spines or tubercles and marked with transverse striæ; lateral margins unarmed. Rostrum triangular, simple. A small tooth on the margin of the orbit within the outer orbital angle. First and second joints of the antennæ with a spine at the outer angle; acicle oblong, straight; last two joints of the peduncle subcylindrical. Last two joints of the maxillipeds not dilated. Chelipeds very unequal, not flattened; hands rounded, fingers excavated within. Ambulatory legs subcylindrical; dactyls spiny below and armed with long, sharp claws. Abdomen soft, loosely inflexed.

Type.-D. Mandtii BRANDT.

\section{Dermaturus Mandtii Brandt. Pl.I. f. 16}

Dermaturus Mandtii BrandT, Bull. phys.-math. Acad. imp. sci. St. Petersb., Tome VIII, 1850, p. 50; Mélanges biologiques, Tome I, 1850, p. 58. Stimpson, Proc. Acad. Nat. Sci. Phila., 1858, p. 232. Bouvier, Ann. Sci. nat. (7), Tome XVIII, 1895, p. 173; Ibid. (8), Tome I, 1896, p. 19.

Hapalogaster Mandtii Schalfeew, Mélang. biol., Tome XIII, 1892, p. 332, figs. 2 and $5 c$, du Bull. Acad. imp. sci. St. Petersb., Tome XXXV, 1892, p. 338.

Carapace narrowly lyrate, not much wider behind than in front, the upper surface unarmed, but marked with prominent, transverse striæ, the anterior edges of which are furnished with short, appressed setio. Rostrum prominent triangular, having a minute kuob of granules just behind the acute tip. Outer orbital angles acute, reaching about as far forward as the middle of the rostrum; a small, but prominent tooth on the transverse posterior margin of the orbit a short distance internal to the onter angle. Eye-peduncles with transverse, setose ridges. The spine at the 
outer angle of the second joint of the antenna is long and narrow, reaching beyond the middle of the acicle; acicle narrow, oblong, straight, the tip rounded, the margins, especially the inner, setose. The last two joints of the maxillipeds are not dilated. Chelipeds with transverse granulated ridges which are furnished with a fringe of appressed setro on the distal side; merus of the large cheliped with 5-6 teeth on the anterior margin; carpus armed in front with three teeth, the proximal one being quite prominent; hand crossed by double rows of granules which become broken up into separate groups on the pollex; fingers with tufts of setæ; merus of the small cheliped armed in front with several spines which decrease rapidly in size towards the distal end; anterior margin of the carpus with three teeth, the proximal one much the largest; hand narrow, anterior margin of the palm with four small teeth at the ends of lines of granules; fingers hairy, longer than the palm; a group of granules above the base of the dactyl. Ambulatory legs crossed with setose striæ; claws long and sharp.

Described from two specimens obtained from the National Museum.

Pribyloff Is. (Brandt); Kadiak Is.; Behring Is. (Schalfeew); lat. $55^{\circ} 34^{\prime} 30^{\prime \prime} \mathrm{N}$; ; lon. $162^{\circ} 31^{\prime} 45^{\prime \prime}$. W.; 19 fathoms!

\section{Genus Edignathus Benedict.}

Carapace lyrate, convex, devoid of spines or tubercles and furnished with a short simple rostrum. Antennal acicle flattened, the inner margin thick and concave, the outer thin and convex; last two joints of the peduncle subcylindrical; flagellum long. Maxillipeds subpediform; the last two joints dilated. Chelipeds unequal; tips of the fingers excavated within. First three pairs of ambulatory legs subequal, subcylindrical; dactyls with curved, corneous claws. Abdomen soft, thick, broad, and loosely inflexed, the basal, and to a less extent, the last two segments strengthened by calcareous plates.

Type.-O. Brandti (SCHaLfeEw).

This genus is closely allied to Dermaturus with which it has been united by Bouvier. It differs from Dermaturus in having a more or less crescent-shaped acicle, in the different marking of the carapace, and in not having the last two joints of the maxillipeds dilated. 


\section{Edignathus Brandti (Schalfeew).}

Hapalogaster Brandti SchaLFeEw, Mélang. biol., Tome XIII, 1892, p. 330, figs. 1 and 5b, du Bull. Acad.imp. sci. St. Petersb., Tome XXXV, 1892, p. 336 .

Edignathus Gilli Benedict, Proc. U. S. Nat. Mus., Vol. XVII, 1894, p. 487. Dermaturus Gilli Bodvier, Ann. Sci. nat. (8), Tome I, 1896, p. 19.

Carapace lyrate, convex above, and covered with flat scale-like plates which are setose on the anterior margin. Rostrum short, triangular, acute and curved downwards. Outer orbital angle subacute, the inner orbital tooth represented by a minute prominence. Upper surface of the antennal acicle furnished with minute spines; lower surface smooth. Chelipeds very unequal and covered with low, granulated, wart-like tubercles; in the larger cheliped the anterior margin of the merus is produced and cut into three or four teeth; the anterior margin of the carpus is furnished with a jagged tooth near the base; the hand is large and swollen, the fingers are somewhat gaping at the base, the tips excavated within. In the smaller cheliped the process on the anterior side of the merus is generally cut into two small teeth; a tooth on the anterior margin of the carpus; the hand is narrower and less tumid than in the large cheliped; the fingers are deeply excavated within and meet along the entire inner margin; outer margin corneous like the tip and armed with a few small teeth. Ambulatory legs more or less hairy; a group of small spines on the inferodistal angle of the propodi; dactyls ending in black, curved, acute tips and armed below with five or six black spines. Abdomen covered with a short pubescence; the margins fringed with long hairs; the calcareous plates on the last two segments inconspicuous. Four two-jointed, uniramous appendages on the left side of the abdomen in the female. The margin of the left side of the abdomen in the female is hardened and segmentally incised, but this is not the case in the male.

Length of carapace from tip of the rostrum to the posterior emargination, $15.5 \mathrm{~mm}$; breadth, $15.5 \mathrm{~mm}$; length of large cheliped, $40 \mathrm{~mm}$.; length of small cheliped, $28 \mathrm{~mm}$.

Alaska (Benedict)! British Columbia! Humboldt County, Calif., to San Francisco Bay! Silte sehulfecer)

This species is often found on the rocks among the mussels. It may be easily recognized by its lyrate carapace covered by the very peculiar scale-like plates and the very unequal chelipeds with their wart-like tubercles.

Through the kindness of Mr. Benedict I have examined the types of his Gilli (No.18525, U. S. Nat. Mus.). 


\section{Edignathus inermis (St.).}

Hapalogaster inermis Stmpson, Ann. N. Y. Lyc. Nat. Hist., Vol. VII, 1860, p. 243. Schalfeew, Mélang. biol., Tome XIII, 1892, p. 326, du Bull. Acad. imp. sci. St. Petersb., Tome XXXV, 1892, p. 332. Newcoube, Bull. Nat. Hist. Soc. Brit. Col., 1893, p. 2S. Boovier, Anu. Sci. Nat. (7), Tome XVIII, 1895, p. 172.

Dermaturus inermis Bouvier, Ann. Sci. Nat. (8), Tome I, 1896, p. 19.

"Carapace longer than broad, smooth above except where some minute transverse, setose scabrosities or minute squamro are sparsely distributed, occurring most abundantly toward the sides. Margins unarmed, smooth. No sinus at the juncture of the cervical suture with the lateral margin. Rostrum convex above, almost carinated; apex scarcely acute. Inner orbital tooth minute, inconspicuous. Outer orbital tooth (antero-exterior angle of the carapax) far less prominent than the rostrum. Acicle rather short and broad, irregularly somewhat dentated along the exterior margin. Feet subcylindrical, almost naked, rugose above with minute and somewhat rounded setose tubercles; dactylus three-fourths as long as the penult joint and armed with a long unguiculus. Plates of the first joint of the abdomen narrow.

"Length of carapax, 0.4 ; breadth posteriorly, 0.38 inch."

Puget Sound (Stimpson); Queen Charlotte Is. (Newcombe); Sitka (Schalfeew).

Judging from Stimpson's description, O. Brandti is very closely related to this species and not improbably will prove identical with it. The setose squamæ in the specimens of Brandti I have seen were thickly set instead of "sparsely distributed," the upper surface of the carapace being almost entirely covered by them, except a small, narrow area along the median line, where they were small and scattered. Stimpson's specimen was probably immature and the character that separates Brandti may be due to age. In all the characters except the abundance and distribution of the squamæ Brandti agrees with Stimpson's description. Schalfeew considered his Brandti closely allied to, if not identical with inermis, and Bouvier, who had a specimen of the latter 
at hand, states that it agrees perfectly with the description and figures of Brandti. The specimen Bouvier called inermis, however, may not have been that species, for if it agreed perfectly with Schalfeew's description and figures of Brandti, it could not agree perfectly with Stimpson's description of inermis. The figure of Brandti shows the squamæ on the carapace to be thickly set.

\section{Genus Acantholithodes Holmes.}

Carapace lyrate, flattened, and covered with setose spines. Rostrum prominent and terminated by strong spines. The first basal joint of the antennæ has one or more spines on the outer side; the second basal joint is produced forwards on the outer side into a long, pointed process whose outer margin is armed with several strong spines; acicles pointed, spiny, joined to the end of the second joint above the spiny process; fourth and fifth bisal joints subcylindrical. The ischium of the maxillipeds is widened, produced forward at the antero-internal angle, and dentate on the inner margin; the last two joints of the palp are not markedly dilated. The legs are covered with setose spines; chelipeds of moderate size; more. or less unequal; fingers excavated within and furnished with calcareous teeth and corneous extremities. First of the three pairs of ambulatory legs subequal. Abdomen soft, the integument spiny; the first and last two segments strengthened by calcareous plates.

Type.-A. hispidus (Strmpson).

\section{Acantholithodes hispidus (St.).}

Dermaturus hispidus Strmpson, Ann. N. Y. Lyc. Nat. Hist., Vol. VII, 1860, p. 242. Whiteaves, Can. Nat. (2), Vol. VIII, 1878, p. 471. Bouvier, Ann. Sci. Nat. (7), Tome XVIII, p. 174 et seq., PI. XI, figs. 3 and 16 ; I894, Pl. XII, figs. 2, 16, and 31; Ibid. (8), Tome I, 1896, p. 19.

Acantholithodes hispidus Holmes, Proc. Cal. Acad. Sci. (2), Vol. IV, 1895, p. 575.

Carapace flattened, lyrate, covered with long setose spines, which become somewhat larger towards the margins. Median region tumid and separated from the cardiac by a very deep, transverse sulcus; a prominent depression between the median and branchial regions. Rostrum quite large and ending in three spines; a large fourth spine above and behind the median one. 
Eye-peduncles hispid and retractile against the anterior margin of the carapace. Antenuules large. Antenna shorter than the carapace; first basal joint with a spine on either side; second joint produced into a long acute process whose onter margin is armed with four or five spines; acicle narrow, acuminate, armed externaily with numerous spines and about equaling the lower spiny process. Ischium of the maxillipeds with two small, subconical teeth on the outer surface near the antero-internal angle; merus hispid, not dilated, and longer than the ischium; last joint of the palp flattened below. Chelipeds unequal, very spiny; two or three very large spines on the anterior margin of the merus and carpus; in the larger hand the palm is inflated, the fingers deflexed, shorter than the palm, excavated within, corneous tipped, and furnished with calcareous, molar-like teeth. In the smaller hand the palm is not so strongly inflated, the fingers are longer and straighter and more deeply excavated within; the corneous tips are more extensive and the calcareous teeth are smaller and more numerous. Ambulatory legs spiny, somewhat compressed; dactyls about two-thirds the length of the propodi. Abdomen short, broad, and soft, the spines not so large as on the carapace; on the basal segment there is a median plate and two wide lateral ones; the plate on the penultimate segment is oblong; the last one is small, rounded, and about as long as wide.

Length of carapace from tip of rostrum, $58 \mathrm{~mm}$; wid th of carapace, $56 \mathrm{~mm}$.

Monterey (Stimpson)! Vancouver's Is. (Whiteaves); "California"!

A rare species. Stimpson's description was drawn from a small female which was somewhat broader than long, .85 in. by .9 in. Our description is taken from a single male from Monterey collected by Dr. Ritter.

\section{Genus Phyllolithodes Brandt.}

Carapace triangular, and provided with rounded tubercles which surround an excavated area on the dorsal surface; lateral margins armed with spines. Rostrum prominent, ending in two cornua. Acicle of the antennæ cut into prominent lobes. Chelipeds unequal, spinose. Ambulatory legs subcylindrical and armed with spines. Abdomen furnished with calcareous plates in which is a central membranous area.

Type.-P. papillosus Brandt. 


\section{Phyllolithodes papillosus Brandt.}

Phyllolithodes papillosus Brandt, Bull. phys.-math. Acad. St. Petersb., Tome VII, 1849, p. 175. Stimpson, Journ. Bost. Soc. Nat. Hist., Vol. VI, 1857, p. 476; Proc. Acad. Nat. Sci. Phila., 1858, p. 231; Ann. N. Y. Lyc. Nat. Hist., Vol. VII, 1862, p.80; Whiteaves, Can. Nat. (2), Vol. VIII, 1878, p. 471. Bouvier, Ann. Sci. Nat. (7), Tome XVIII, 1895, p. 174, Pl XI, fig. 12; Pl. XII, figs. 14 and 25; Pl. XIII, fig. 1; Ibid. (8), Tome I, I896, p. 22.

Petalocerus bellianus White, Proc. Zool. Soc. London, 1856, p. 134, P1. XLII; Ann. Nat. Hist. (2), Vol. XV, 1855, p. 307 . Bate, Proc. Zool. Soc. London, 1864; in Lord's Nat. in Vanconver's Is., Vol. II, 1866, p. 275 .

Carapace triangular and covered with strawberry-like tubercles which form a smaller elevated triangle whose sides are parallel to the sides of the carapace; a pair of large, deep pits on the dorsal surface. Rostrum prominent, divided into two, blunt, diverging, obliquely compressed horns, and bearing on the upper side a high, bilobed crest. On the under side of the rostrum there is a spiny process directed forwards and curving slightly upwards, above the base of which is a pair of much smaller spines. Antero-lateral margin constricted behind the hepatic regions. A subacute spine at the outer orbital angle which is directed forwards, downwards, and slightly inward; two spines of unequal length just external to the postorbital; behind the constriction, the antero-lateral margin is armed with three, long, slender, rather blunt spines which exceed the anterior ones in length. The postero-lateral angles of the carapace are produced outwards into flattened expansions which bear three blunt projections, the anterior one of which is elongated, slightly compressed, pointing upwards, outwards and forwards; the posterior projection is short and rounded. Posterior margin of the carapace transverse and furnished with a row of rounded tubercles. Antennal acicle furnished with three smooth, flattened, subequal, spatulate processes. The chelipeds are unequal and thickly covered with long, slender, more or less compressed, blunt spines, which are largest on the merus and carpus and gradually diminish in size toward the tip and lower margin of the hand; the two hands are similar; fingers stout, corneous-tipped, and excavated, the outer sides furnished with numerous tufts of setæ. Ambulatory legs subequal, subcylindrical, and thickly covered with long spines similar to those of the chelipeds. Basal abdominal segment mearly vertical and deeply pitted on either side like the following segments.

Length of carapace from tip of the rostral horn, $52 \mathrm{~mm}$; width between tips of postero-lateral horns, $51 \mathrm{~mm}$.

Kadiak Is. (Brandt); Vancouver's Is.(Bate, Whiteaves); Monterey (White); "California", several specimens! 


\section{Phyllolithodes bicornis (Bate).}

Petalocerus bicornis BATE, Proc. Zool. Soc. London, 1864, p. 664; in Lord's Nat. in Vancouver's Is., Vol. II, 1866, p. 271.

Phyllolithodes bicornis Bouvier, Aun. Sci. Nat. (8), Tome I, 1896, p. 22.

This species is evidently closely allied to papillosus. The carapace is "anteriorly produced into two, horizontal, horn-like processes. The second pair of antenni have a compound scale, consisting of two large and two short compressed processes, and a third joint is furnished with two or three sharp, short strong processes." This species differs from papillosus, according to Bate, "in having a horizontal, bifurcate rostrum to the carapace, being more distinctly tuberculated, and in the pereopoda being more strongly spinated."

Color, yellow, with purple between the tubercles.

"Dredged in Esquimalt Harbor in ten fathoms of water."

The character of the rostrum does not distinguish this species from papillosus, as I have seen in the latter species all stages between prominent rostral spines and short, blunt knobs. Of the other distinguishing characters I cannot speak. Had not Bate specimens of papillosus from near the same locality for comparison, one would be inclined to regard this species as a synonym of the preceding one.

\section{Genus Cryptolithodes Brandt.}

Carapace transverse, nearly smooth, high in the middle and produced laterally into two wing-like expansions which cover the ambulatory legs. Rostrum broad, flattened, deflexed. Antero-lateral margins arcuate, often dentate, and meeting the postero-lateral margins at an angle. Ocular peduncles quite slender and approximated at their enlarged bases. Antemnules separated by a considerable interval, the first joint enlarged. First basal joint of the antennæ very short; second joint with a crest above and a large process on the outer side; acicle broad and laminate; flagellum rather short. Ischium of the maxillipeds small, the inner margin denticulated; merus with the outer surface flattened; joints of the palp compressed. Chelipeds unequal and more or less covered by the carapace; hands stout, compressed, the fingers excavated within. The three anterior pairs of 
ambulatory legs are subequal, crested above for a part of their length; dactyls with curved, acute tips. Abdomen flattened, triangular, fitting neatly into a depression in the sternum; behind the entire basal segment the abdomen bends abruptly, and the three following segments are divided into a median row of plates with a series of lateral plates on either side; the penultimate segment is devoid of lateral plates and conceals the minute, triangular telson.

T'ype.-C. typicus Brandt.

\section{Cryptolithodes typicus Brandt.}

Cryptolithodes typicus Brandt, Bull. phys-math. Acad. St. Petersb., Tome VII, 1849, p. 175; and Tome XI, 1853. Strmpson, Journ. Bost. Soc. Nat. Hist., Vol. VI, 1857, p. 472, Pl. XIX; Proc. Acad. Nat. Sci. Phila., 1858, p. 231. Bate, Proc. Zool. Soc. London, 1864; in Lord's Nat. in Vancouver's Is., Vol. II, 1866, p. 271. Bouvier, Ann. Sci. Nat. (7), Tome XVIII, 1895, p. 189, and (8), Tome I, 1896, p. 28.

Carapace very wide. Rostrum very much deflexed, not distally widened, the upper surface rounded, the anterior extremity truncated with the angles rounded. Lateral angles of the carapace acute; the posterior margin bulges outward very slightly in the middle. Seen from below the carapace is strongly concave and not at all flattened out towards the sides. The depression between the cardiac and median region is shallow. Teeth on the posterior margin of the carapace obscure; those on the anterolateral margin small. Orbital sinus much less deep than in sitchensis. Chelipeds very low, rounded tubercles; large hand with the outer surface tuberculated and the upper side rounded; small hand acute above. The merus joints of the ambulatory legs are furnished below with a deep groove bounded by the sharp, produced, lower margins. Abdomen crossed by transverse ridges.

Described from a small, dried specimen in the U.S. National Museum (No. 3475) collected by Dall at Belkoffsky Bay, Alaska (25 fathoms).

Northern California (Brandt); Monterey (Stimpson); Vancouver's Is. (Bate). 


\section{Cryptolithodes sitchensis Brandt. Pl. II, f. 21-25.}

Cryptolithodes sitchensis BRANDT, Bull. phys.-math. Acad. imp. sei. St. Petersb., Tome XI, 185̃3, p. 133; Mélanges biologiques, Tome I, p. 654. Strupson, Journ. Bost. Soc. Nat. Hist., Vol. VI, 1857, p. 476; Proc. Acad. Nat. Sci. Phila., 1858, p. 231. Newcombe, Bull. Nat. Hist. Soc. Brit. Col., 1893, p. 26, Pl. XI: Bouvrer, Ann. Sci. Nat. (7), Tome XVIII, 1895, p. 189, Pl. XI, figs. 11 and 15, Pl. XII, fig. 26; Ibid. (8), Tome I, 1896, p. 28.

Cryptolithodes alta-fissura BAte, Proc. Zool. Soc. London, 1864, p. 665; Ann. Nat. Hist. (3), Vol. XV, p. 485; in Lord's Nat. in Vancouver's Is., Vol. II, 1866, p. 271.

Carapace transversely subelliptical; median region high and surmounted by a ridge or crest, which extends to the middle of the front anteriorly; a pair of transverse ridges extending upon the hepatic region from the sides of the median eleration. Behind the median region the carapace is much inflated and rounded and furnished with a rounded elevation behind the depression at the posterior end of the median area. Median ridge obsolescent on the posterior portion of the carapace. Surface of the carapace smooth, microscopically very closely punctated, and furnished here and there with very small, rounded tubercles which, in some specimens, are almost entirely absent. The rostrum is deflexed at an angle of about 45 degrees and widened towards the distal end, which is transverse and furnished with a small median tooth. The lateral expansions of the carapace are produced forwards to about two-thirds the length of the front, forming a large deep, rounded, orbital sinus on either side. The antero-lateral margins are strongly arcuated, curving most sharply a little in front of the middle, the posterior third being almost straight and much more nearly longitudinal than transverse; the antero-lateral teeth are eight to ten in number and separated by concave interspaces of variable length; they are small and variable, often subacute, but sometimes represented by small undulations. The lateral angles of the carapace much exceed 90 degrees, and the lateral teeth are larger than those in front. Posterior margin strongly arched, and generally devoid of teeth, although there may be one or two small ones near the lateral angles. A very prominent longitudinal crest on the pterygostomian regions. The ocular peduncles are smooth, bent upwards, and flattened above, the bases much enlarged. The superior crest on the second joint of the antennæ is short and high and the laminate outer process is triangular, produced at the postero-external angle, and extending forward in a sharp point considerably exceeding the fourth joint of the peduncle; the fifth joint is strongly compressed, having a high, thin crest on the upper side, which is produced at the distal end; flagellum nearly naked, scarcely as long as the peduncle; the acicle is very 
thin, unarmed, about as wide as long, concave above, very strongly curved externally, the upturned inner margin somewhat irregular and nearly straight. The ischium of the maxillipeds is small, trigonal, the outer angle furnished with a small tooth; of the two edges which face the middle line, the imner one is the longer and finely denticulated, the outer one is furnished with two rounded teeth; the merus is smooth, flattened, strongly produced at the outer angle, the inner and outer margins sharp, the onter surface transversely concave; the joints of the palp are strongly compressed and crested above. Chelipeds stout; inner margin of the ischium acute; inner margin of the merus with a compressed (occasionally subconical) tooth; the carpus has a ridge on the outer surface, an acute projecting distal margin, and a tooth over the upper hinge joint of the hand; hands smooth, compressed, with a single, rounded, longitudinal ridge a little below the middle of the outer surface; the high upper crest is produced at the distal end; fingers short and stout, dactyl with a superior crest which is most prominent at the proximal end. Ambulatory legs smooth, naked, strongly compressed, with the upper edges acute; the lower side of the merus is flattened, not deeply grooved as in typicus; the acute inferior margin of the propodi ends distally in a short spine; dactyls spinulous below, about three-fourths the length of the propodi. The sides of the abdomen in the male are nearly straight, but in the female they are convex and more or less unequal; the basal joint is nearly vertical, with a depression on either side of the center; the posterior side more strongly concave in the female than in the male; the sutures of the median and lateral pieces alternate, those between the lateral pieces being transverse in the male but oblique on one side in the female, the penultimate segment is oblong, distally widened, and concave at the distal end; the telson is very small and fits into the space between the bases of the chelipeds.

Length of Carapace.

Width of Carapace.

\begin{tabular}{|c|c|}
\hline Male .........47 & 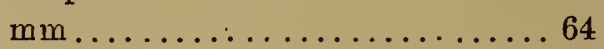 \\
\hline$\ldots 36$ & $\ldots \ldots 53$ \\
\hline$\ldots 35$ & $\ldots \ldots \ldots \ldots 50$ \\
\hline$\ldots \ldots \ldots 32$ & $\operatorname{mm} \ldots \ldots \ldots \ldots \ldots \ldots \ldots 4$ \\
\hline “ $\ldots \ldots \ldots \ldots 16$ & $\operatorname{mm} \ldots \ldots \ldots \ldots \ldots \ldots \ldots \ldots \ldots \ldots \ldots \ldots \ldots$ \\
\hline
\end{tabular}

Female.......36.5 mm ................ $49.5 \mathrm{~mm}$.

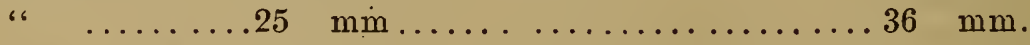

The males I have seen in a fresh condition were all of a uniform, bright red color! Two (females seen were red but with a purplish tinge irregularly marked with blotches of a lighter color, This species is often seen at low tide on the sides of rocks where, at some distance, 
it might readily be mistaken for a species of bright red incrusting sponge which is found in similar situations.

Near Sitka (Brandt); Alaska! Vancouver's Island (Bate); Victoria; Queen Charlotte Island (Newcombe); British Columbia (Bouvier); Port 'Townsend! Cape Mendocino! Point Arena, Calif.!

In young specimens the posterior margin of the carapace is straighter than in adults; the ridge on the outer surface of the hand is plainer and there may be one or more additional ridges more or less plainly visible. In females the posterior portion of the carapace is very tumid, and the posterior margin bulges backwards more strongly than in the males.

\section{Cryptolithodes brevifrons Miers.}

Cryptoluthodes brevifrons MILer, Proc. Zool. Soc. London, 1879, p. 48, Note. Boovier, Ann. Sci. Nat. (8), Tome 1, 1896, p. 28.

This species is described in a foot-note as follows:

"There is a dried specimen in the [British] Museum from Vancouver's Island which closely resembles $C$. typicus, but is distinguished by the form of the rostrum, which is obtusely triangular, and does not project beyond the anterior margin of the carapax. This I propose to call C. brevifrons."

\section{Genus Lopholithodes Brandt.}

Carapace broad, pentagonal or hexagonal, convex above; with the margins and upper surface armed with setose tubercles. Rostrum short, spiny. Acicle of the antennæ with the margins and generally the upper surface spiny. The terminal joint of the mandibular palp is elongated and flattened, and bent backward so as to lie between the concave inner faces of the mandibles. Chelipeds unequal, tuberculated; carpus with a prominent lobe on the inner side. Ambulatory legs short, tuberculated, and capable of being folded under the carapace. Basal segment of the abdomen 
entire, the three following segments with lateral plates and also small marginal plates on one or both sides; penultimate joint devoid of lateral plates; telson very small.

Type.-L. Mandtii Brandt.

Large crabs of rough aspect, confined to the Pacific Coast of North America.

In this genus the chelipeds and ambulatory legs, when folded, fit neatly together, thus affording protection to the mouth-parts and under side of the body in a very effective manner.

Until the present time Lopholithodes Brandt has been ranked as a synonym of Echinocerus White, the date of Brandt's genus being given as 1849 and that of White's as 1848. But while Vol. VII of the Bulletin of the St. Petersburg Academy of Sciences bears the date 1849, the number containing the description of Lopholithodes bears the date of publication June 29, 1848. The part of the Proceedings of the Zoological Society of London in which White's description of Echinocerus appeared was received from the printer November 14, 1848. The name Lopholithodes, therefore, has priority.

\section{Lopholithodes Mandtii Brandt.}

Lopholithodes Mandtii Brandt, Bull. phys.-math. Acad. St. Petersb., . Tome VII, 1849, p. 174.

Echinocerus cibarius WhIте, Proc. Zool. Soc.London, 1848, p. 47, Pls. II and

III; Cat. of Crust. in Brit. Mus., p. 56. Stmpson, Journ. Bost. Soc. Nat. Hist. Vol. VI, 1857, p. 477; Proc. Acad. Nat. Sci. Phila., 1858, p. 231. Bate, in Lord's Nat. in Vancouver's Is., Vol. II, 1866, p. 276. Whiteaves, Cau. Nat. (2), Vol. VIII, 1878, p. 471. Newcombe, Bull. Nat. Hist. Soc. Brit. Col., 1893, p. 26. Bouvier, Ann. Sci. Nat. (7), Tome XVIII, 1894, p. 184, Pl. XI, fig. 13, Pl. XII, figs. 13 and 24; Ibid. (8), Tome I, 1896, p. 27.

Ctenorhinus setimanus Gibbons, Proc. Cal. Acad. Sci., Vol. I, 1855, p. 48. Échinocerus sentimanus Strmpson, Proc. Cal. Acad. Sci., Vol. I, 1856, p. 88; Journ. Bost. Soc. Nat. Hist. Vol. VI, 1857, p. 477; Proc. Acad. Nat. Sci. Phila., 1858, p. 231. Bouvier, Ann. Sci. Nat. (7), Tome XVIII, 1894, p. 184; Ibid. (8), Tome I, 1896, p. 27. 
Carapace strongly convex, wider than long, the whole surface-the large tubercles as well as the intervening spaces-roughened by small short, setose tubercles which vary greatly in size from low, nearly smooth swellings to rough, subconical projections. Median region very prominent, having a subconical apex a little in front of the middle and a cluster of small, rounded, or subacute tubercles near the posterior end; a large, subconical elevation on the cardiac region in front of which, on either side, is a depressed, comparatively smooth area; median and cardiac areas separated by a comparatively smooth sulcus; a large subconical elevation on the branchiai regions and two smaller tubercles on the posterior margin of the carapace. A peculiar smooth wart-like prominence on either side of the median area. Rostrum short and consisting of a strong subconical spine above the base of which is a knob bearing two lateral spines or tubercles with (generally) a spine or tubercle above and below the notch between them. A deep, rounded sinus on either side of the front which serves as an orbit, external to which is an acute spine; beyond this spine is a large spine which extends nearly as far forwards as the rostrum and in the sinus between the latter spine and the postorbital there is generally a small spine or tooth. The antero-lateral margin is armed with a variable number (about eight) of prominent spines and several smaller ones; the middle portion is convex, flattened, and produced. A large, knob-like prominence at the postero-lateral angles which is separated from the last antero-lateral spine by a conspicuous sinus. Ocular peduncles two-jointed, thickly set with spines above, and not nearly reaching the tip of the rostrum. Acicle of the antennæ narrow, tapering, much exceeding the tip of the peduncle, and furnished with about thirty strong, smooth, sharp spines. Ischium of the maxillipeds armed within with dark-colored teeth; a tooth on the outer surface near the antero-internal angle; exognath somewhat exceeding the merus. Chelipeds short, the first and second joints with irregular tuberculous projections on the under side; one or more prominent spines on the antero-internal angle of the merus; the lobe on the inner side of the carpus is very large and acute and margined with sharp, spine-like tubercles; spines on the outer surface of the hands large and numerous; four or five large spines on the upper margin of the larger hand and three or four on that of the smaller. Ambulatory legs subequal, strongly tuberculated, quadrangular at the base; carpi and propodi subcylindrical but very irregular; dactyls short and stout. The basal abdominal segment is strongly concave behind, especially in the female, and nearly at right angles to the carapace; there are two prominent tubercles near the middle and several on the margins; the remaining segments are studded with numerous subconical tubercles; between the median plates there are small, transverse, secondary plates which may be divided by longitudinal fissures; penultimate segment oblong and distally concave. 
The abdomen of the male is subtriangular behind the basal segment; that of the female rounded at the sides and tip and bent to one side.

Length, $200 \mathrm{~mm}$; breadih, $245 \mathrm{~mm}$.; length of larger cheliped, $202 \mathrm{~mm}$.; length of first ambulatory leg, $195 \mathrm{~mm}$. Some specimens are widest between the tubercles at the postero-lateral angles, while others are widest between the tips of the last spines on the antero-lateral margin.

Sitka (Brandt); Vancouver's Is. (Bate); near the mouth of the Columbia River (White); Farallon Islands! Monterey!

\section{Lopholithodes foraminatus $(S t)$}

Echinocerus foraminatus Stimpson, Ann. N. Y. Lyc. Nat. Hist., Vol. VII, 1860, p. 79. Newcombe, Bull. Nat. Hist. Soc. Brit. Col., 1893, p. 27, Pl. III. Bouvier, Ann. Sci. Nat. (7), Tome XVIII, 1894, p. 184; Ibid. (8), Tome I, 1896, p. 27.

Carapace depressed, wider than long, the tubercles on the upper surface mostly small and subconical; median region elevated, furnished with a conical tubercle near the middle, and a group of smaller tubercles near the posterior end; cardiac region with a few subconical tubercles; an irregular line of tubercles extending from the median area to the postero-lateral angles of the carapace; the greater portion of the upper surface is covered with depressed, more or less papillose elevations. A smooth spot on either side of the median area as in Mandtii. Rostrum rather short, with the median spine much as in Mandtii and a cluster of spiny tubercles above the base. External to the orbits there are three spines in a nearly transverse line, behind which the antero-lateral margin is at first concave, then strongly convex; the spines on the convex portion of the margin are large and subconical; behind the convex part the margin is concave and devoid of spines; posterior margin of the carapace arcuated and studded with conical tubercles. Eye-stalks spinulous. Antennal acicle with strong spines on the margins but aimost devoid of spines on the upper surface. Chelipeds very spiny; merus with the antero-internai angle produced and with a flattened, nearly semicircular area at the supero-distal angle; carpus with the inner lobe prominent, and with the outer edge excavated, forming a smooth, deep, rounded sinus which, when approximated to the shallower corresponding sinus on the anterior edge of the carpus of the first pair of ambulatory legs, forms a smooth, nearly circular hole; hands quite similar to those of Mandtii. Ambulatory legs and abdomen much as in the preceding species. 
"Near San Francisco" (Stimpson); Farallon Islands! Victoria (Newcombe).

Easily recognized by the remarkable foramen between the chelipeds and the first ambulatory legs.

\section{Genus Lithodes Latr.}

Carapace broad, more or less depressed and spiny. Rostrum generally prominent and armed with spines. The large basal segment of the abdomen may be entire or composed of three or more plates; the three following segments are furuished with median, lateral, and marginal plates.

\section{Lithodes Rathbuni Benedict.}

Lithodes Rathbuni Benedict, Proc. U. S. Nat. Mus., Vol. XVII, 1894, p. 482.

Paralithodes? Rathbuni Bouvier, Ann. Sci. Nat. (8), Tome I, 1896, p. 23.

Carapace armed with four spines on the gastric area and four (two long and two short ones) on the cardiac; branchial region with six spines. Rostrum composed of five branches, the main stem sharply bent npward and deeply bifurcate; the lower spine projecting nearly horizontally. The right cheliped is rather slender; the carpus has more than twelve spines; palm with two rows of four spines each on the median, outer surface. Ambulatory legs slender and very spiny. Antennal acicle very long and slender.

Known from a single male specimen taken off San Simeon Bay, Calif., in 211 fathoms.

\section{Lithodes californiensis Benedict.}

Lithodes californiensis Benedict, Proc. U. S. Nat. Mus., Vol. XVII, 1894, p. 483.

Paralithodes? californiensis Bodvier, Ann. Sci. Nat. (8), Tome I, 1896, p. 23.

Very closely allied to $L$. Rathbuni, but having the spines on the carapace shorter and stouter and the rostrum simply bifid instead of divided into two, well-developed horns. 
Known from two female specimens taken off Santa Cruz Island, Calif., in 155 fathoms.

There are several other species of Lithodes found further north on our coast, viz., L. brevipes, camtschaticus, cequispinus, and Couesi. Panamensis occurs on the west coast of Central America.

\section{Legion PAGURINEA.}

\section{The Hermit Crabs.}

Carapace elongated, generally membranaceous behind the cervical groove. Rostrum small. Abdomen generally long and unprotected by calcareous plates. First two pairs of ambulatory legs well developed, last two pairs small. Last abdominal segment furnished with a pair of ap. pendages.

Species usually inhabiting the coiled shells of Molluses.

\section{Family PAGURID瓜.}

Antennular peduncle of moderate size, the first joint short and stout, second and third slender and cylindrical; both flagella small. The peduncle of the antenna is subcylindrical; acicle lanceolate. Gills phyllobranchiate. Abdomen soft, asymmetrical.

\section{Genus Pagurus Fabr.}

Front with a rostral projection. Ocular peduncles with the basal scale of moderate size and wide apart. Antennal acicle slender and elongated; flagellum long and naked. Chelipeds rarely subequal, the right usually the larger. Fourth pair of pereopods subchelate. First and second abdominal segments without genital appendages. Males without a protruded vas deferens.

Type.-Pagurus Bernhardus (Lins.).

It has been recently pointed out by Mr. J. E. Benedict $^{1}$ that the generic name Eupagurus will have to be superseded by the older name Pagurus. "I believe,"

1 Ann. Nat. Hist. (6), Vol. XVIII, July, 1896, p. 99. 
says Mr. Benedict, "that the genus Pagurus, as now constituted, does not contain a single one of the original species placed in it by Fabricius; but be that as it may, a valid and therefore imperative reason for making the change lies in the fact that Bernhardus was designated as the type of Pagurus by Latreille in $1810^{1}$." The old genus Pagurus was divided by Brandd in his work on Crustacea in Middendorff's Siberische Reise ${ }^{2}$ into several subordinate sections or subgenera, one of which containing Bernhardus and its allies was called Eupagurus or the true Pagurius. Brandt's subgenus Eupagurus was afterwards raised to the rank of a genus with Bernhardus as the typical species, thus depriving the older genus of its type. Eupagurus must, therefore, give way to the older name.

The species of the genus Pagurus are very numerous and often difficult to determine. The west coast of North America seems especially rich in these forms. The Albatross collections in museums of the University of California and the California Academy of Sciences have been of especial value to me in studying our species of this genus, and at the U. S. National Museum, through the kindness of Mr. Benedict, I have examined some species from this coast not previously met with. At one place or another I have seen all the species of Pagurus here described.

A few Atlantic species have been reported from this coast: P. Kröyeri from Puget Sound by Stimpson, and Bernhardus from the north Pacific by Brandt. The Bernhardus as Mr. Benedict suggests (in litt.) may be aleuticus or alaskensis.

The genus Pagurus is divided by Mr. Benedict into four subgenera as follows: 


\section{Subgenus Eupagurus.}

Pagurus "with the large surface of the left hand horizontal. Species not inclined to be hairy."

Typical species, P. Bernhardus (Linn.).

$P$. aleuticus, alaskensis and ochotensis belong here. All a re large species with the upper surface of the left hand triangular and the edges prominent.

\section{Subgenus Trigonocheirus.}

Pagurus "with the outer face of the left hand oblique and more or less triangular. In some cases it is flattened, in others concave, or very much swollen as in hirsutiusculus. The species are frequently very hairy."

Typical species $P$. trigonocheirus Stimpson.

This group includes the greater number of the species here described, viz., trigonocheirus, capillatus, Dalli, Brandti, Rathbuni, Tanneri, confragosus, Newcombei, Kennerlyi, hirsutiusculus, Samuelis, minimus, granosimanus, and Hemphillii.

In many of the species the left hand is small and rounded, presenting no distinctly outlined upper face. In others the left hand is trigonous, with a well-defined, triangular face bounded by prominent edges. The first five species mentioned are very closely allied. In all three the chelipeds are very unequal, the carpus of the larger one oblong with the sides flattened and the upper surface furnished with short spines or spiny granules; the hand is oblong, evenly convex above, and armed like the carpus; the smaller hand has a prominent, triangular supero-external face. Rathbuni can be distinguished by the peculiar round pubescent patch on the upper side of the carpus. Tanneri and confragosus are distinguished from all the others by the ridge on the upper surface of the larger hand. Newcombei can be 
recognized by the bright red tips of the chelipeds and dactyls. Kennerlyi has the spines on the upper surface exceptionally long and slender. Hirsutiusculus, granosimanus, Samuelis and Hemphillii are small, littoral species. They are the forms most commonly met with along the shore at low tide. Granosimanus may readily be distinguished from the other three by its rounded, median, frontal projection and its broader left hand. Hirsutiusculus may be recognized by its strong pubescence, the short anterior portion of the carapace, and short eye-stalks.

\section{Subgenus Elassocheirus.}

Pagurus "with the left hand very small, in some cases almost rudi. mentary. The large hand is always wide or broadly ovate, excepting in munitus and Gilli where the carpus is exceedingly wide and the hand moderately so. Eye-scale semicylindrical, grading to triangular, sharp and pointed. Species not hairy; many of them smooth and glabrous."

Typical species, P. tenuimanus (DaNa).

Besides the type the only species of this group in our limits are munitus and californiensis.

\section{Subgenus Labidocheirus.}

Pagurus "with the manus of the left cheliped cylindrical."

Typical species, P. splendescens (OwEN).

\section{Pagurus alaskensis (Benedict).}

Eupagurus alaskensis Benedict, Proc. U. S. Nat. Mus., Vol. XV, 1892, p. 2.

Anterior portion of the carapace a little wider than long and sparingly pubescent. Median tooth of the front triangular, acute, and produced considerably beyond the lateral ones, which are rounded, but furnished with a small spine. Ocular peduncles short, stout, constricted in the middle, and about one-half the length of the anterior portion of the carapace. Eye-scales subovate, with the apex blunt or subacute, the upper surface concave and the subterminal spine visible from above. Antennal acicle trigonous, reaching much beyond the tips of the ocular peduncles; 
the upper surface flat, the inner margin spinulous and pubescent. Chelipeds spinulous, markedly unequal, and almost devoid of pubescence. Merus of the larger cheliped oblong, trigonous, the upper surface with a few transverse, granulated, or spinulous rugæ near the distal end; carpus with the inner and outer sides flattened, the upper surface convex and spinous, with a row of stout spines on the inner edge; hand oblong, slightly wider than the carpus; inner side flattened; upper surface moderately convex and covered with acute granulations; outer margin defined by a row of spiny granules; fingers armed within with tuberculous teeth. Merus of the smaller cheliped compressed; carpus with the inner side flattened, the supero-lateral surface convex and covered with spiny granules; outer margin raised; upper surface convex; upper internal margin armed with a row of strong spines, external to which is a similar row on the upper surface; hand oblong, flattened, and covered with sharp granules; outer margin raised; upper surface convex, the inner surface of the palm and dactyl flattened; dactyl much longer than the palm, the upper surface rounded. Ambulatory legs with the merus and propodus spinulous above, the dactyls long, curved, twisted, becoming thinner but not decreasing in width towards the tip, and pectinated below with slender, closely set, parallel spinules.

Concerning the color of this species Mr. Benedict says: "In alcoholic specimens the general color above is a light purple with iridescent reflections; below light tinged with reddish. A red streak runs around the prehensile edge of the thumbs and behind the dactyls to the inner margins of the hands. There is an oblong patch of red on the outer distal margins and on the upper surface of the merus joints of the cheliped. The lower outer surface of the carpal joints of ambulatory legs is pointed with red. The propodal joints and dactyls are longitudinally streaked with red.) This species is very close to Bernhardus but is easily distinguished by its broader and shorter left hand, by the wide dactyls of the ambulatory legs, by the acicula, and by its pearly iridescence."

\section{Alaska; off Washington in 31 to 38 fathoms (Bene- dict).}

\section{Pagurus aleuticus (Benedict).}

Eupagurus aleuticus Benedict, Proc. U. S. Nat. Mus., Vol. XV, 1892, p. 3.

Closely allied to alaskensis. The teeth on the front are sharper, the lateral ones acute. Eye-peduncles stouter and over one-half the length of the anterior portion of the carapace. Antennal acicle similar to that of alaskensis but broader at the base and not projecting so far beyond the tips of the eye-peduncles. The chelipeds are very similar to those of alaskensis but the spines are more prominent; a prominent line of spiny granulations 
on the upper surface of the dactyl, which is represented only by an obtuse ridge in the preceding species. On the dactyl of the smaller hand there is an oblique, smooth surface visible from above which is not found in alcuskensis, and the supero-erternal surface of the carpus of the smaller cheliped is much more flattened and the onter edge of the hand more elevated and more sharply spinose. The dactyls are similar in form to those of alaskensis, but are easily distinguished by the deep sulci on the upper side bounded by sharp, minutely spinulous edges.

\section{Aleutian Is. (Benedict).}

\section{Pagurus ochotensis (Brandt).}

Eupagurus ochotensis Braxdr, Middendorff's Sibirische Reise, Bd. II, Th. 1, 1S5̃1, p. 108. Stiupsox, Proc. Acad. Nat. Sci. Phila., 1858, p. 248. Bernhardus armatus Dasa, Proc. Acad. Nat. Sci. Phila., 1851, p. 269;

Crust. U. S. Expl. Expd., Part I, 1852, p. 442, Pl. XXVII, fig. 2. Eupagurus armatus Stimpsox, Journ. Bost. Soc. Nat. Hist., Vol. VI, 1857, p. 4S4. Bate in Lord's Nat. in Vancouver's Is., Vol. II, 1866, p. 278. Whiteaves, Can. Nat. (2), Vol. VIII, 1878, p. 471.

Anterior portion of the carapace wider than long; the three projections of the front about equally advanced. Ocular peduncles short and stout, but little over one-half the leugth of the anterior portion of the carapace. Eye-scales acute, with a prominent, subterminal tooth. Acicle slender, flattened above, and extending far beyond the eyes. Chelipeds spiny, the carpus of the larger one with the sides flat and sharply gramulated, the upper surface evenly rounded and spiny, with a row of longer spines along the inner margin; hand oblong, evenly rounded above, and spiny like the carpus; dactyl with a row of spines on the outer edge and another row near the middle of the outer surface. Smaller cheliped reaching a little beyond the base of the dactyl of the larger one; carpus and hand spiny above, the inner edge of the palm somewhat raised and armed with two rows of spines, the outer spines being the shorter. The meral, carpal, and propodal joints of the ambulatory legs are spinous above; the dactyls are spinous, twisted, grooved on each side, and nearly as long as the two preceding joints. A large species.

Described from specimens (No. 14951) in the U.S. National Museum.

Puget Sound (Dana); Sitka! San Diego, Calif.! 


\section{Pagurus trigonocheirus (St.)}

Eupagurus trigonocheirus Stimpson, Proc. Acad. Nat. Sci. Phila., 1858, pp. 237 and 249. Mordoch, Rep. Int. Polar Expd. to Pt. Barrow, Part IV, 1885, p. 138, Plate I, figs. $1,1 a$ and $1 b$. Benedict, Proc. U. S. Nat. Mus., Vol. XV, 1892, p. 1 .

The three prominences of the front are subequal, the lateral ones ending in a minute spine. The anterior portion of the carapace is longer than wide and more or less pubescent; a tuft of hairs on the median projection of the front. Eye-slalks rather stout and much shorter than the width of the carapace. Eye-scales subovate, acute, more or less pubes. cent and not at all channeled above. Acicle rounded, pubescent, and reaching the tip of the ocular peduncle. Chelipeds pubescent; right cheliped with the ischium denticulated on the lower margin; merus trigonal, supero-lateral surface much rounded and scabrous; lower surface spinulous; the supero-distal margin spiny; carpus thick, oblong, the upper surface convex and covered with short spines; inner and outer surfaces flattened and less strongly spinose; hand oblong, slightly narrower than the distal end of the carpus; the upper surface convex and covered with short spines; inner margin obtuse; outer margin subacute, except near the base, and spinulous; lower surface spinulous near the margins; fingers shorter than the palm; dactyl narrower than the pollex, with a spinulous, subacute outer margin and a longitudinal row of short spinules on the upper surface. Smaller cheliped reaching beyoud the carpus of the larger one; merus compressed, spinulous below; carpus compressed, distally widened, especially on the lower side, the upper margin spinulous; hand trigonous, the supero-lateral face wide, flattened, subspinulous or granular, the edges acute; the upper edge is the longer, with the posterior portion convex and spinulous, the spinules becoming smaller on the pollex; dactyl narrow and nearly smooth. Ambulatory legs scabrous or spinulous on the margins; the two small posterior pairs are smooth and strongly pubescent.

Length, 3 inches.

Arctic Ocean and Behring Sea (Stimpson); Alaska!

\section{Pagurus capillatus (Benedict).}

Eupagurus capillatus Benedict, Proc. U. S. Nat. Mus., Vol. XV, 1892, p. 8.

Anterior portion of the carapace a little longer than wide. Median frontal lobe broadly rounded. Ocular peduncles more than two-thirds as long as the anterior portion of the carapace, and slender. Acicle not reaching to the tip of the eye. Hand of larger cheliped twice as long as 
wide and rather sparsely set with sharp, stout spines. Hand of smaller cheliped narrow, slender, with the supero-exterual surface narrower than in trigonocheirus, and the edges not so strongly produced. Dactyls of the ambulatory legs slightly twisted.

Very near pubescens from the Atlantic. For an enumeration of the differences, see Benedict, l. c., p. 9.

Alaska; Washington in 40 fathoms (Benedict).

\section{Pagurus Brandti (Benedict).}

Eupagurus Brandti Bexedict, Proc. U. S. Nat. Mus., Vol. XV, 1892, p. 9.

Median portion of the frout triangular and produced scarcely beyond the lateral teeth. Eye-stalks rather stout. Acicles scarcely extending beyond the eyes. Hand of the larger cheliped twice as long as wide. Hand of the smaller cheliped as in trigonocheirus. Ambulatory legs almost entirely unarmed; dactyls slender, slightly twisted and longer than the propodi. Color of alcoholic specimens "everywhere reddish. Spines everywhere red or red pointed."

Aleutian Islands (Benedict); Captain's Harbor, Unalaska, 80 fathoms!

\section{Pagurus Dalli (Benedict).}

Eupagurus Dalli Bexedict, Proc. U. S. Nat. Mus., Vol. XV, 1892, p. 9.

Very closely allied to Brandti. Median lobe of front triangular, acute, and produced further beyond the lateral teeth than in Brandti. Eyepeduncles more slender than in Brandti or trigonocheirus. Acicle reaching but little beyond the eyes. The carpus of the small cheliped is not so high, and the supero-external surface of the hand is not nearly so wide at the base as in the last two species. The dactyls of the ambulatory legs are long, more slender than in Brandti, and not twisted.

Aleutian Islands, Unalaska (Benedict); Iluliuk Harbor, 10 fathoms!

"This species," says Benedict, "is closely allied to Kröyeri, trigonocheirus, and Dalli. The small chelipeds of all have the triangular outer face, and in general the species resemble each other very much. With a large series of all I find substantial specific characters. 
Brandti and Dalli are found together in a depth of from 15 to 85 fathoms in the Aleutian Island region. They grow to a length of three inches. They are separated at sight by a sharply defined band of white on the distal end of the merus joints of Dalli, which is entirely wanting in Brandti."

\section{Pagurus Rathbuni (Benedict).}

Eupagurus Rathbuni Benedict, Proc. U.S. Nat. Mus., Vol.XV, 1892, p. 14.

Near trigonocheirus, but with the median projection of the front acute and projecting considerably beyond the lateral teeth. Eye-peduncles stout, not two-thirds as long as the anterior portion of the carapace. Eyescales ovate, concave above, with a subterminal spine. Chelipeds resembling those of trigonocheirus; the hand of the larger one over twice as long as wide. Hand of the smaller cheliped much narrower than in trigonocheirus, the edges not nearly so prominent; fingers curved downwards. Ambulatory legs spinulous above; dactyls twisted, longer than the propodi, and nearly devoid of spinules with the exception of a few on the lower side near the tip.

Alaska.

This species is distinguished from all the other hermit crabs of the coast by the possession of a circular patch of fine hairs on the antero-internal angle of the upper surface of the carpus of the large cheliped. It is also distinguished from the four preceding species by its larger median frontal prominence.

\section{Pagurus Tanneri (Benedict).}

Eupagurus Tanneri Benedict, Proc. U. S. Nat. Mus., Vol. XV, 1892, p. 10.

Anterior portion of the carapace as wide as long. Median frontal tooth triangular, much larger and projecting much further forward than the lateral teeth, which are broadly triangular, subacute, and furnished with a terminal spine. Ocnlar peduncles stout; corner dilated; scales ovate and furnished with a subterminal spine which is visible from above, the upper surface more or less concave. The outer spine of the second basal antennai joint reaches to, or beyond the middle of the fourth joint; acicle 
slender and exceeding the tips of the ocular peduncles. Chelipeds spinulons and pubescent; merus oblong, the supero-lateral surface rounded and scabrous, or spinulous; lower surface spinulous, and deroid of marked prominences; carpus thick, oblong, the inner and outer surfaces flat; upper surface convex, spinous, with the inner and onter edges defined by rows of spines; hand about as wide as the carpus and over twice as long as broad; on the upper surface behind the gap between the fingers is a longitudinal ridge, which is continued forward upon the pollex though diminishing in size; the ridge bifurcates behind, forming two lower, less marked ridges which diverge toward the posterior margin; on either side of this ridge the surface of the hand is depressed and less spiny than elsewhere; fingers flattened and bent downwards; a row of short spinules on the outer margin of the dactyl and a similar row near it on the upper surface. Merus of the smaller cheliped compressed, spinulous below; carpus compressed, but widened at the distal end of the lower side, having a rounded, spinulous process at the antero-external angle; upper edge with two series of spines; hand trigonous, supero-external face subtriangular, deeply concave; edges prominent, spinulous; a row of spinules extending from the proximal margin to the upper ridge, which it meets a short distance from the base; the surface below the upper edge is concave and limited below by a row of spinules; fingers curved downwards; dactyl slender, nearly smooth. Ambulatory legs subequal, spinulous above; dactyls slender, longer than the propodi, quite strongly twisted, and obsoletely spinulous.

\section{Alaska; off Washington from 167 to 559 fathoms (Benedict).}

\section{Pagurus confragosus (Benedict).}

Eupagurus confragosus Benedict, Proc. U. S. Nat. Mus., Vol. XV, 1892, p. 11.

Very near Tanneri. The median lobe of the front is acute but not so prominent as in that species. Ocular peduncles short, stout, distally widened, and not two-thirds the length of the anterior portion of the carapace. Chelipeds much like those of Tanneri; the larger hand is slightly wider, with the outer margin more curved; the triangular area between the two diverging ridges of the upper surface is wider, and the more prominent inner ridge is interrupted at about its posterior third, the two parts changing direction at this point; the elevated apex of the triangle where the ridges meet is not continued forward as a high crest as in Tanneri, but the ridge begins to descend immediately toward the pollex; fingers much flattened, but scarcely curved downward. Smaller hand scarcely distinguishable from that of Tanneri. Ambulatory legs subequal; dactyls slender, curved, twisted, nearly devoid of spinules. 
"The two species," says Benedict, "are readily separated by the inner side of the raised triangle of the larger hand. In this species it cuts off the inner depression of the upper surface from the proximal margin of the palm, while in T'anneri this depression is allowed to reach the margin by a curvature of the ridge."

Alaska! off Washington and the mouth of the Columbia River in 68-178 fathoms (Benedict).

\section{he wing ances, \\ Pagurus = Newcombei (Benedict).}

Eupagurus Newcombei Benedict, Proc. U. S. Nat. Mus., Vol. XV, 1892, p. 17.

Anterior portion of the carapace longer than wide. Median frontal tooth short and obtuse; the lateral teeth broadly rounded and slightly prominent. Eye-stalks moderately slender and a little over one-half the length of the anterior portion of the carapace. Eye-scales subtriangular, slightly concave above, the subterminal spines prominent. Antennal peduncles longer than the eye-stalks; acicle nearly reaching the tip of the eye. Chelipeds very unequal; merus of the larger one stout; the onter surface is convex and nearly smooth, but there are some transverse spinulous rugæ near the supero-distal angle; two prominent tubercles on the lower side; carpus oblong, scarcely one-half longer than wide, and of nearly equal width throughout; outer surface flat; inner surface a little concave; upper surface evenly convex, thickly covered with spiny granules, and bordered on the inner side by a row of short spines, internal to which is a parallel row of smaller spines; hand no wider and scarcely longer than the carpus, and covered above with spiny granules; outer edge acute, especially on the pollex, and armed with short spines; fingers with minute, corneous tips; dactyl margined with spiny granules. Small cheliped pubescent; merus compressed, and more or less spinulous below; carpus armed with ten or twelve long, curved spines on the upper edge; outer surface with several spines on the upper side and spiny granules further down; hand longer than the carpus, with a triangular, spinulous, superoexternal face; a sulcus on the posterior portion of the upper edge. The carpus and propodus of the ambulatory legs are armed above with spines, which are much smaller in the second pair, where they may be absent on the propodi; dactyls spinous below and about as long as the propodi.

Color in alcohol: chelipeds reddish, the tips of the fingers bright red. The ambulatory legs are spotted with red; the base of the dactyls and the distal end of the propodi are bright red.

British Columbia (Benedict); Sitka! Port Townsend! 


\section{Pagurus Kennerlyi (St:).}

Eupagurus Kennerlyi Stimpsox, Proc. Acad. Nat. Sci. Phila., 1864, p. 153. Bexenict, Proc. U. S. Nat. Mus., Yol. XV, 1592, p. 19. Walker, Trans. Liverpool, Biol. Soc., Vol. XII, 1898, p. 275.

Anterior portion of the carapace a little longer than wide. Median tooth of the front triangular, low, subacute; lateral teeth rounded, with a prominent submarginal spine making them appear acute. Eye-peduncles moderately slender and fully two-thirds the length of the anterior portion of the carapace; corner not large and scarcely dilated. Eye-scales suborate, dorsally concare, with a prominent subterminal spine, which is visible from above. Antennal peduncle exceeding the eyes; acicle rounded above and seldom reaching the tip of the eye. Chelipeds very unequal, pubescent, and spiny; merus nearly trihedral, the outer surface convex and nearly smooth; carpus short, distally widened; inner surface smooth, glossy, more or less concave; outer surface flattened, nearly smooth; upper face corered with scattered hairy prominences; inner edge furnished with seven or eight slender curved spines; a parallel row of three or four spines near the distal end; hand oblong, wider and much longer than the carpus; upper surface with seven to nine rows (including the marginal rows) of spines, a tuft of long hairs arising from the base of each spine; fingers corneous tipped; outer margin of the dactyl with a prominent row of short spines and a similar row on the upper surface. Merus of the left cheliped with the lower side spinulous; carpus compressed, with a double row of spines on the upper surface; hand with the supero-external surface widened at the base and thickly set with strong spines; upper edge with a smooth sulcus. Ambulatory legs pubescent, the upper sides devoid of spines except on the carpus of the anterior pair; dactyls not twisted, about equalling the propodi and armed below with slender spines.

Alaska (Benedict); Puget Sound (Stimpson)! Kadiak Is., lat. $55^{\circ} 35^{\prime} 30^{\prime \prime} \mathrm{N}$.; ion. $162^{\circ} 31^{\prime} 45^{\prime \prime} \mathrm{W}$.; 19 fathoms!

\section{Pagurus hirsutiusculus (Dana).}

Bernhardus hirsutiusculus Dana, Proc. Acad. Nat. Sci. Phila., 1851, p. 269;

Crust. U. S. Expl. Expd., Part 1, 1852, p. 443, Pl. XXVII, fig. 3.

Eupagurus hirsutiusculus Stimpson, Journ. Bost. Soc. Nat. Hist., Vol. VI, 1857, p. 484; Proc. Acad. Nat. Sci. Phila., 1858, pp. 237 and 249.

Carapace and legs pubescent; anterior portion of the carapace a little wider than long; median tooth triangular and acute; lateral teeth obsolete. Ocular peduncles short, about one-half the length of the anterior portio $n$ of the carapace; cornfæ scarcely dilated. Fye-scales oblong 
obtuse, concave on the upper side, with the subterminal spine visible from above. Antero-external process of the basal antennal joint short and stout, not reaching the middle of the fourth joint of the peduncle, and double pointed; acicle rounded, pubescent on the inner side, and not reaching the middle of the last joint of the peduncle. Chelipeds very unequal; merus of the larger one trigonal, with the angles rounded and the surfaces convex and marked with small, transverse, granulated, pubescent rugæ; carpus oblong, distally widened, the sides rounded and the upper surface very convex; surface covered with pubescent, granulated rugæ similar to those on the merus, which become broken up, in many places, into separate granules; hand oblong, nearly twice as long as wide, the upper surface evenly convex and granulated; fingers short and stout, the dactyl with a row of granules on the upper side parallel to the outer edge. Smaller cheliped with the merus and carpus compressed and granulo-scabrous; hand small, narrow, with the sides rounded and having no prominent angles; palm more or less inflated, with often a trace of a groove near the proximal end of the upper surface; surface of the hand granulated; fingers pubescent with corneous edges. Ambulatory legs granulo-scabrous, but not spinous, except on the lower side of the dactyls and the distal end of the propodi; dactyls nearly straight, almost as long as the propodi, and not twisted.

Alaska! Behring Is.! Puget Sound; Oregon; northern to southern California! Common on the shore at low tide.

\section{Pagurus Samuelis (Stimpson).}

Eupagurus Samuelis Stimpson, Proc. Bost. Soc. Nat. Hist., Vol. VI, 1857, p. 86; Journ. Bost. Soc. Nat. Hist., Vol. VI, 1857, p. 482; Proc. Acad Nat. Sci. Phila., 1858, p. 250; Ann. N. Y. Lyc. Nat. Hist., Vol. VII, 1860, p. 90, Pl. I, fig. S. ORtmann, Zool. Jahrb. Abth. f. Syst., Bd. VI, 1892, p. 301, Pl. XII, fig. 12.

Closely allied to hirsutiusculus. Body and legs quite strongly pubescent. Anterior portion of the carapace considerably longer than wide. Median tooth of the front quite prominent and sharp; lateral teeth represented only by a slight convexity in the margin. Ocular peduncles moderately stout, somewhat constricted in the middle, and about one-half as long as the anterior portion of the carapace. Ocular scales subovate and dorsally concave, with the subterminal spine visible from above. Antennal peduncle exceeding the eyes by fully one-half the length of the last joint; acicle rounded above, pubescent on the inner margin, not reaching the middle of the last joint of the peduncle, but nearly reaching the tip of 
the eye-stalk. Chelipeds very unequal, the larger one elongated, granulated, nearly devoid of pubescence, but furnished with minute setro which arise from the base of the granules; merus compressed, the angles rounded, length about one-half greater than the height; outer surface convex and more or less granulo-rugose toward the distal end; carpus in the adult a little over one-half longer than wide, the upper surface evenly convex and rounded off to the sides, the onter of which is granulated and more or less flattened; inner side somewhat more strongly granulated and slightly concave; on the posterior portion of the carpus there are several transverse, granulated rugre which become gradually replaced anteriorly by isolated, rounded gramnles; hand oblong (but not twice as long as wide), broader than the carpus, becoming more elongated with age; upper surface evenly convex and grannlated like the curpus, the granules becoming longer on the pollex; outer margin acute, grannlo-denticulate, the granules becoming less sharp with age; fingers shorter than the palm; outer margin of the dactyl granulo-denticulate; a granulated line on the upper surface parallel to the margin; tips of the fingers corneous in yonng, but calcareons in old specimens. Smaller cheliped pubescent, not reaching the base of the dactyl in adults, and often scarcely reaching the base of the hand; merus spinulous below; carpus compressed, the upper edge armed with nine or ten sharp spines external to which is a parallel row of smaller spines; the granulations on the lower surface become more or less spiny towards the anterior margin; hand granulated, narrow, oblong, not shorter than the merus; palm rounded, having no prominent ridges or angles; fingers corneous tipped. Ambulatory legs pubescent, the propodi granulo-spinose above; dactyls rather stout, spinous below, and markedly shorter than the propodi. The dactyls are of a bluish color with a longitudinal reddish stripe on the sides; distal end of the propodi bluish.

Patrick's Point! Mendocino County! Pescadero! Monterey (St.)! Santa Catalina Is.! San Pedro! San Diego! Japan (Stimpson, Ortmann).

I very strongly doubt that the $E$. Samuelis reported from Japan by Stimpson and Ortmann is the same as our California species.

\section{Pagurus minimus, sp. nov.}

Anterior part of the carapace abuut as wide as long; median projection of the front triangular, acute, the lateral ones rounded. Eye-scales pointed, with a very prominent subterminal spine. Ocular peduncles stout, cylindrical, a little flattened distally, and about two-thirds the length of the anterior portion of the carapace, reaching about the middle of the 
last joint of the antennal peduncle. Acicle short, slender, nearly reaching the tip of the cornew, but not reaching the middle of the last joint of the peduncle. Chelipeds pubescent; merus of the larger one compressed, the angles rounded; carpus one-half longer than broad, distally widened, the upper surface rounded, not sharply marked off from the lateral faces, and armed with short spines which are inclined forwards; inner face convex, but less so than the outer, which is evenly rounded; hand oblong, widening distally to a short distance beyond the base of the dactyl; the base of the hand is armed with spines, which are inclined forwards like those of the carpus, and is strongly convex longitudinally, giving the hand the appearance of being bent downwards; pollex broad, the outer edge evenly rounded, sharp, upturned, and armed with anteriorly directed spines, the upper surface smooth and concave; dactyl broad, widest a little beyond its articulation, the outer margin sharp, spiny, evenly curved, the upper surface nearly smooth and concave; inner margin of both fingers furnished with large, white, tubercular teeth; lower side of the hand evenly convex from side to side, the distal two-thirds longitudinally nearly straight, tapering evenly to the tip of the pollex. Hand of small cheliped narrow, rounded, the upper face oblique; fingers longer than the palm. Ambulatory legs rather slender and pubescent; dactyls slender, curved, tapering from the base, spiny below, and longer than the propodi.

General color reddish, with spots of darker red; larger cheliped a darker red than the rest of the body, especially at the distal end; ocular peduncles with a median, transverse, light-colored band.

Length, three-eighths of an inch.

Described from a single female specimen dredged in 30 fathoms off San Diego, February 11, 1899. The specimen carried numerous pale green eggs.

This species is best distinguished by the character of the larger hand, which is convex at the narrow base, both longitudinally and transversely, while the distal portion is nearly smooth, longitudinally straight, but transversely concave. Collection University of California.

\section{Pagurus granosimanus (St.)}

Eupagurus granosimanus Stimpson, Ann. N. Y. Lyc. Nat. Hist., Vol. VII, 1860, p.90. Sмгтн, Rep. Prog. Geol. Sur. Canada, 1878-9, B, p. 211.

Anterior portion of the carapace a little longer than wide. Median tooth of the front broad and rounded; lateral teeth represented only by slight convexities of the margin. Ocular peduncles moderately stout, and 
about two-thirds the length of the anterior portion of the carapace; corner transverse and scarcely dilated. Eye-scales subovate, more or less concave on the dorsal surface, the subterminal spine visible from above. Antennal aeiole reaching but little beyond the eyes, exceeding them by much less than half the length of the terminal joint; acicle not nearly reaching the corner or the middle of the last joint of the peduncle. Chelipeds very unequal, the right one elongated in adults, devoid of pubescence, and strongly granulated; merns a little less than one-half longer than high, the auterior portion of both lower edges denticulated; lower surface furnished with two rounded tubercles; outer surface convex and roughened as in Samuelis; carpus oblong, more than one-half longer than wide, but not twice as long; upper surface evenly convex and strongly granulated; sides flattened; upper edges rounded; hand oblong, nearly twice as long as wide, slightly wider and about one-sixth longer than the carpus, the upper surface evenly convex and granulated, the granules becoming larger on the pollex; outer margin acute, especially on the pollex, and granulo-dentate; dactyl nearly as long as the palm, the outer edge acute, granulo-dentate; tips of the fingers calcareous; smaller cheliped nearly devoid of pubescence; merus compressed; carpus rather stout, the upper margin sharp and armed with 5-7 spines; the upper part of the external surface is more or less spiuulous, the lower portion granulorugose; hand oblong, wider than the carpus, and longer than the carpus or merus; the supero-external surface rather wide at the base and strongly granulated; supero-internal edge marked proximally by a ridge, external to which is usually a slight groove. Ambulatory legs spinous on the upper edges; dactyls spinous below and armed with smaller spines above, shorter than the propodi, not twisted, and armed with long, corneous claws.

Color in alcohol reddish; legs dark and marked with small bluish spots behind the small tufts of setæ; granules bluish.

\section{Monterey (Stimpson)! San Pedro! San Diego! Pesca-} dero! Patrick's Point, Humboldt County, Calif.! Puget Sound!

\section{Pagurus Hemphillii (Benedict).}

Eupagurus Hemphillii Benedict, Proc. U. S. Nat. Mus., Vol. XV, 1892, p. 16.

Closely allied to granosimanus and Samuelis. Carapace glossy, the anterior portion much longer than broad. Median tooth acute, the lateral teeth represented by a convexity in the margin. Eye-stalks rather sleuder and about two-thirds the length of the anterior portion of the carapace. Eye-scales subovate, more or less concave above, and subacute, the subterminal spine visible from above. The antennal peduncle somewhat 
exceeds the eye-stalk but not by one-half the length of the last joint; acicle small, much shorter than the eye-stalk, not reaching the posterior third of the last joint of the peduncle. Chelipeds markedly unequal; merus strongly compressed, the outer surface quadralateral, nearly smooth, but marked more or less as in Samuelis; anterior portion of both lower margins denticulated; a small tubercle at the lower posterior angle; carpus oblong, deep, twice as long as wide, the sides flattened, the upper surface convex, thickly granulated, with the edges rounded, there being no definite lateral margins; hand oblong, no wider than the carpus at the base, but widening distally, being broadest near the base of the dactyl; upper surface evenly convex and granulated like the carpus; outer edge acute; dactyl shorter than the palm. Merus of the left cheliped with the outer part of the lower margin spinulous; carpus with nine or ten spines on the sharp upper edge, external to which is a parallel row of much smaller spinules; hand much compressed, scarcely wider than the carpus, its broad, outer face nearly parallel with the inner one; a groove on the upper surface extending from the posterior margin nearly to the dactyl and margined on either side by spiny granules. Ambulatory legs slender, much compressed, the carpus and propodus of the anterior pair (and especially the right member) spinulous on the upper surface; dactyls spiuulous below, scarcely as long as the propodi and not twisted.

Color in alcohol, bright red, the tips of the dactyls light colored.

"California" (Benedict); Humboldt County, Calif.!

\section{Pagurus tenuimanus (Dana).}

Bernhardus tenuimanus Dana, Proc. Acad. Nat. Sci. Phila., 1851, p. 269; Crust. U. S. Expl. Expd., Part I, 1852, p. 447, Pl. XXVII, fig. 7.

Eupagurus tenuimanus Stimpson, Journ. Bost. Soc. Nat. Hist., Vol. VI, 1857, p. 483; Proc. Acad. Nat. Sci. Phila., 1858, p. 237. Sмгтн, Rep. Prog. Geol. Sur. Canada, 1878-9, B, p. 211. Benedict, Proc. U. S. Nat. Mus., Vol. XV, 1892, p. 1. W WLKeR, Trans. Liverpool Biol. Soc., Vol. XII, 189S, p. 274.

Carapace smooth, naked. Median process but little more prominent than the lateral teeth which end in a minute spine. Eye-scales narrowly oblong, subacute, channeled above, and having a minute subterminal spine not visible from above. First three joints of the antennal peduncle armed as in munitus; acicle rounded, the inner side pubescent, the tip reaching as far as, or a little beyond the ocular peduncles; flagellum long. Chelipeds very unequal; merus of the larger cheliped short, trigonous, with the sides convex, the length and breadth subequal; surface more or less tuberculated, especially near the supero-distal angle, which is furnished with several marginal spines; extero-distal angle with a few spines; carpus 
stout, a little longer than wide, the upper surface strongly convex and thickly corered with small, sharp tubercles; inner edge spinous; hand very wide and strougly flattened, with the edges produced into prominent, thin expansions, which make the hand much widor than the carpus; both surfaces thickly covered with small tubercles; inner edge of the hand convex, denticulated, and curved downward in the middle; fingers strongly compressed and hollowed ont above, both sides minntely tuberculated or granulated. Left cheliped with the merus flattened, denticulated on the upper margin and at the infero-distal angle; carpus compressed, upper surface granulated or tuberculated, the inner edge acute and spinous; hand flattened, similar in shape to that of munitus, but the raised margins are denticulated; upper surface granulated or minutely tuberculated, the proximal margin overlapped by, instead of overlapping, the distal margin of the carpus; lower surface smooth; fingers more or less pubescent. Ambulatory legs nearly naked, and marked with red spots; upper margins spinulous; dactyls slightly twisted, considerably longer than the propodi, the margins and anterior surface spinulous; sides of the preceding joints smooth and glossy.

Length of large cheliped, $81 \mathrm{~mm}$.; merus, $19 \mathrm{~mm}$.; width of same, 16 mm.; carpus, $26 \mathrm{~mm}$; width of same, $24.5 \mathrm{~mm}$; hand, $34 \mathrm{~mm}$., greatest width of same, $29 \mathrm{~mm}$; length of smaller cheliped, $51 \mathrm{~mm}$.

\section{Puget Sound (Dana); Kadiak Is., Alaska!}

\section{Pagurus californiensis (Benedict).}

Eupagurus californiensis Benedict, Proc. U. S. Nat. Mus., Vol. XV, 1892, p. 21. Faxox, Mem. Mus. Comp. Zool. Harvard College, Vol. XVIII, 1895, p. 55, Pl. XI, fig. 2-2e.

Median tooth of the front low and scarcely in advance of the broadly triangular lateral teeth. Ocular peduncles moderately stout and about three-fourths as loug as the anterior portion of the carapace, which is nearly as wide as long. Eye-scales oblong, subacute, deeply channeled above, and curved downward, the subterminal spine small. Acicle rounded, pubescent on the inner margin, and not reaching the tips of the ocular peduncles. Chelipeds of exceptionally unequal size; larger cheliped glossy; merus trigonous, the surfaces convex and nearly smooth, but siightly roughened with scattered, minute prominences; carpus much widened at its distal end where its breadth about equals its length; upper surface convex and furnished with scattered, depressed granulations; outer margin raised and finely granulated; inner margin prominent and armed with several short, unequal spines; outer surface more or less flattened; inner surface oblique and slightly concare; hand flattened, much wider 
than the carpus, and nearly as broad as long; upper surface evenly convex and covered with sharp granulations of unequal size; outer margin acute, denticulated, and evenly curred from the tip of the pollex to the base; inner margin produced, acute, more strongly denticulated than the outer, and ending in a prominent angle some distance from the base of the dactyl; fingers compressed; pollex very wide and furnished with several large granulations; dactyl with the upper margin sharply granulated and furnished with a granular line on the surface, between which and the outer margin the surface is deeply concave. Merus of the smaller cheliped compressed, narrow, and smooth, except on the lower side, which is spinulous toward the distal end; carpus compressed, armed above with two rows of spines, the included surface being slightly concave; hand small, oblong, with no prominent angles, a little longer than the carpus, but not exceeding the merus. Ambulatory legs glossy, nearly smooth; a spine at the supero-distal angle of the carpus projecting over the propodus; dactyls thin, pubescent, not twisted, and spinulous below, exceeding the length of the propodi.

Color of alcoholic specimens near orange; the ambulatory legs crossed by bands of a lighter color. There is a band of lighter color near the middle of the ocular peduncles.

\section{California (Benedict); Santa Catalina Island! Dredged in the harbor of Avalon.}

\section{Pagurus munitus (Benedict).}

Eupagurus munitus Benkdict, Pròc. U. S. Nat. Mus., Vol. XV, 1892, p. 19.

Carapace smooth, nearly naked, the anterior margin with three nearly equal teeth. Eye-scales oblong, channeled above. First joint of the antennal peduncle with a spine or tooth at the interior antero-inferior angle; second joint with a spine at the antero-internal angle, the inferodistal produced forward into a prominent spine which is generally double pointed; third joint with a spine at the apex; acicle rounded, pubescent on the inner side, and about reaching the tips of the ocular peduncles. Chelipeds very unequal, merus of the right cheliped short, trigonous; carpus broader than long, the margins produced into two large, thin, winglike expansions and curved so that the inner surface is concave; hand smooth, much narrower than the distai end of the carpus, and about twice as long as wide, the edges subparallel; onter edge siightly concave; fingers punctate, shorter than the palm. In the smaller cheliped the carpus is elongated aud compressed, the upper margin spiny; hand oblong, smooth, much flattened, the acute edges upturned, making the upper surface markedly concave; proximal margin acute and overlapping the distal 
end of the carpus; fingers smooth, more or less pubescent below, the dactyl provided with a crest which is a continuation of the elevated margin of the hand; the opposite margin is continued as a similar crest upon the pollex. Ambulatory legs slender, glossy, nearly naked, the upper margins of the last three joints more or less spinulous; dactyls slightly longer tban the propodi.

\section{Alaska!}

\section{Genus Paguristes Dana.}

Front with a distinct rostral projection. Ocular peduncles long and slender, the scales of moderate size. Antennules long. Antennal acicle robust, flagellum ciliated. Chelipeds equal or subequal, the fingers moving in a horizontal plane. Fourth pair of pereopods not chelate. The first two abdominal segments in the male and the first segment in the female bear sexual appendages.

Type.-P. longirostris DaNa.

\section{Paguristes turgidus (St.).}

Eupagurus turgidus Strmpson, Proc. Bost. Soc. Nat. Hist., Vol. VI, 1857, p. 86.

Clibanarius turgidlus Stmpson, Journ. Bost. Soc. Nat. Hist., Vol. VI; 1857, p. 484, Pl. XXI, fig. 1. Bate in Lord's Nat. in Vancouver's Is., Vol. II, 1S66, p. 278. Whiteaves, Can. Nat. (2), Vol. VIII, 1878, p. 471.

Paguristes turgidus Stimpson, Proc. Acad. Nat. Sci. Phila., 1858, p. 236;

Ann. N. Y. Lyc. Nat. Hist., Vol. VII, 1860, p. 86. Sмгтн, Rep. Prog: Geol. Sur. Canada, 1878-9, B, p. 211. WALker, Trans. Liverpool, Biol. Soc., Vol. XII, 1898, p. 275.

Carapace pubescent, the anterior portion longer than wide. Front tridentate, the median tooth much the largest. Ocular peduncles over onethird the length of the anterior portion of the carapace. Antennal acicle armed with several dark-tipped spines on the inner margin; flagellum short. Chelipeds hairy above, the upper surface covered with dark-tipped spines; fingers corneous tipped. Ambulatory legs hairy, the dactyls a little longer than the propodi. Attains a length of about three inches.

Puget Sound (Stimpson); Vancouver's Is. (Smith); Farallon Islands! Santa Catalina Is.!

\section{Paguristes parvus, sp. nov.}

Rostrum long, narrow and acute. Ocular scales cut into three spines. Ocular peduncles pubescent, enlarged at the base, and exceeding the peduncle of the antennr Acicle pubescent, reaching nearly to the tip of 
the peduncle, and having the outer margin armed with short spines; second joint of the peduncle produced, external to the acicle, into a process which is cut into three spines. Legs pubescent. Chelipeds equal, the merus nearly smooth; carpus with a flattened, subtriangular upper surface, the inner and outer margins of which are armed with three or four short, stout spines; hands with the upper surface coarsely granulated; the short inner margin armed with three short, stont spines; a longitudinal intumescence on the upper surface upon which are two rows of smali tubercles; fingers excavated within and having black, corneous tips. The upper margins of the carpi and propodi of the ambulatory legs are spinulous; dactyls scabrous, slender, nearly straight, and longer than the propodi. Length one-half inch.

Three specimens taken at White's Point near San Pedro, Calif., July, 1895.

\section{Collection University of California.}

\section{Paguristes Bakeri, sp. nov.}

Carapace hairy, the anterior portion nearly as wide as long, eroded in front and towards the sides, and having a few short spinules near the antero-lateral margins; front with three, subequal, triangular teeth. Ocular peduncles slender, cylindrical, two-thirds the length of the anterior portion of the carapace, and having a line of hairs on the upper side. Ocular scales armel with several marginal spines which become larger towards the tip. Peduncle of the antennæ nearly three-fourths the length of the eye-stalk; second basal joint with a spine at the antero-internal angle; the antero-external angle produced forward as a large, triangular, acute process which is armed with a few short spines on the outer margin. Acicle rather small, awl-shaped, hairy, reaching a little beyond the middle of the last joint of the peduncle, the inner margin armed with spines and the outer margin furnished near the tip with two spines which point obliquely upwards. Chelipers equal; merus trigonous, the upper anterior end hirsute and spiny and the two lower margins armed with short spines; carpus short, hirsute and spiny above, the inner margin of the upper side armed with abont six spines which increase in size anteriorly; outer face small, hard portion of the lower side reduced to a narrow, transverse bar, inner face flattened, with a concavity on its lower side, and armed with a few spines above and anteriorly; hands short and broad, widest across the base of the pollex, the upper surface flattened, hairy, armed with numerous spines, inner edge straight, the outer very strongly curved, inner faces flattened and armed with small spines, four spines on the inner margin behind the base of the dactyl; pollex rery broad at base; 
lower surface of hand tumid below base of pollex and armed with short spines; an angle of $90^{\circ}$ between its upper and inner faces. Ambulatory legs hairy; carpus of the anterior pair spiny above; propodus armed below with short spinules and above with seven or eight rather strong spines; dactyls flattened, much longer than the propodi, both margins closely set with spines; second pair much less spiny than the first.

There is a pair of very small, simple, two-jointed appendages on the first abdominal segment in the female, but the succeeding four segments have an appendage only on the left side; of these the first three (those on the second, third, and fourth segments) are well-developed and biramous, but the appendage on the fifth segment is smaller and reduced to a single branch. In the male the pair of appendages on the first abdominal segment is larger than in the female and the inner faces are channeled; the second segment has a pair of appendages, and the third, fourth and fifth segments have a uniramous appendage only on the left side.

General color dark reddish; legs more or less colored with blue.

Length of female $2.5 \mathrm{in}$; of males $4.5 \mathrm{in}$. and $5 \mathrm{in.}$

Described from three specimens from San Diego, Calif.: one a female loaned by the San Diego NaturalHistory Society, and two large males. For the opportunity of examining the latter I am indebted to Dr. Fred Baker of San Diego.

This species is allied to $P$. fecundus Faxon, but is distinguished by having a less prominent rostrum, much longer antennal flagellum, shorter dactyls on the second and third pereopods, and small but well-marked spines instead of "obscure teeth," on the terminal lobes of the telson.

\section{Holopagurus, gen. nov.}

Rostrum not prominent. Ocular peduncles moderately long and slender; basal scales close together. Antennal acicle rather short; flagellum hairy. Left cheliped larger than the right; fingers of both hands moving horizontally, their inner margins not excarated. Fourth pair of legs more or less chelate. First abdominal segment of the male devoid of appendages; second, third and fourth segments with an appendage only on the left side. Telson entire.

Type--H. pilosus. 


\section{Holopagurus pilosus, sp. nov.}

Anterior portion of the carapace slightly wider than long, eroded at the front and sides, and having a few short spinules near the antero-lateral margin. Frontal margin transverse, rostral projection represented by a small prominence which does not exceed the lateral ones. Ocular peduncles cylindrical, rather slender, and about two-thirds the length of the anterior portion of the carapace; corner not dilated; basal scales very wide at base, their inner sides produced forwards into a subacute, triangular lobe. Anterinular peduncle about equalling the eye-stalks. Peduncle of the antenum shorter than the eye-stalks, the second joint with a short spine at the antero-external angle but none at the antero-internal angle; last joint of the peduncle short, less than twice as long as wide; acicle straight, ciliated, evenly tapering to an acute tip, convex and roughened above, and not reaching the tip of the peduncle; flagellum shorter than the carapace and thickly set below with long hairs. Chelipeds of similar form, furnished with long hairs and short spines; merus trigonous, the lower side flattened, the upper edge sharp; carpus armed with short, scattered spines on the upper surface which is convex, rounding off insensibly to the small outer face; inner face flattened and separated from the upper surface by a rather sharp edge which is armed with sharp spines and turns outward near the base more sharply on the left cheliped than on the right; hands horizontally flattened, the upper surface gently convex and covered with scattered spines which are larger and more thickly set near the rounded margins; the larger hand is widest across the base of the fingers, beyond which it is quite abruptly contracted; the pollex is rather narrow a short distance beyoud the base, its inner and outer margins rounded, the tip corneous; dactyl subconical, the tip corneous and strongly curved, its surface thickly set, like the pollex, with short, corneous spines. The smaller hand is relatively narrower than the larger one, the inner and outer faces parallel; pollex not so much contracted beyond the base as in the larger hand, its outer margin evenly convex near the base and not slightly concave like that of its fellow. Ambulatory legs hairy and armed with spines on the upper sides of the merus, carpus and propodus; propodi subcylindrical, nearly smooth below; dactyls long, gently curved, flattened towards the tip, subcylindrical at the base, about twice the length of the upper side of the propodi, strongly twisted, and armed only with very short, corneous spinules. Dactyl of the fourth pair of legs extending for about one-third its length beyond the propodus. Coxæ of the last pair of legs separated by an oblong process of the sternum on the posterior side of which is a sharp, median groove. Abdominal appendages long and hairy.

The posterior portion of the carapace is more or less calcified, especially over the cardiac area, and the branchial regions are reticulated with mem. branous lines. 
General color yellowish white; the antennio are blue and the anterior portion of the carapace has more or less of the same coloration; a peculiar reddish coloration occurs on different parts of the body, notably on either side of the cardiac area of the carapace.

Length four inches; large cheliped three-eights of an inch longer than the smaller one.

One large male specimen and several small ones dredged in about 25 fathoms off San Diego, Calif. Collection University of California.

\section{Family PARAPAGURIDÆ.}

Similar to the Paguridæ but having trichobranchiæ, instead of phyllobranchiæ. Deep sea forms.

\section{Genus Parapagurus Smith.}

Resembles Pagurus. Third maxillipeds widely separated at the base. Chelipeds very unequal. Sternum between the first and second pereopods narrow. Eleven pairs of branchiæ, two at the base of the maxillipeds and each of the first three pereopods, and three at the base of the fourth. Well developed and symmetrical pairs of appendages on the first and second abdominal segments in the male.

Type.-P. pilosimanus Sмтн.

\section{Parapagurus Mertensii (Brandt).}

Pagurus Mertensii Braydt, Middendorff's Siberische Reise, Bd. II, Tḥ. 1, 1851, p. 112.

Eupagurus Mertensii Strmpsor, Journ. Bost. Soc. Nat. Hist., Vol. VI, 1857, p. 483; Proc. Acad. Nat. Sci. Phila., 1858, p. 237. Benedict, Proc. U. S. Nat. Mus., Vol. XV, 1892, p. 2.

Anterior portion of the carapace sparsely hairy and about as wide as long. Median frontal tooth prominent, acute, the lateral teeth small. Ocular scales orate, acute, concave above. Eye-stalks short, about onehalf the length of the anterior portion of the carapace. Acicle slender, rounded, sparsely ciliated, curved downwards, much exceeding the eyestalks, but not reaching the tip of the antennal peduncle. Chelipeds pubescent, spiny, very unequal; right cheliped very large; merus armed with a row of short spines on the inner and outer margins of the lower 
side; carpus long, the inner and outer margins spiny, and the convex upper surface armed with two rows of short spines; outer face more or less flattened; lower side bulging and armed with a few short spines; hand long, narrow, dorso-ventrally flattened, and bent inward at a slight angle to the carpus; the rounded upper surface furnished with small, subserially arranged granules which become more prominent on the fingers; inner and outer margins sharp, granulo-denticulate and parallel; lower surface of the palm with a broad, shallow concavity which extends nearly to the dactyl. Left cheliped slender; merus spiny below; carpus subcylindrical, with three rows of spines on the upper surface; hand narrow, much longer than the carpus; palm very short; fingers long, narrow, and curved downwards. Ambulatory legs long, compressed, and very slender; dactyls exceedingly long and slender and armed below with numerous spines.

Described from a single female specimen obtained from the U. S. National Museum from Mr. Benedict, who pointed out' that it was not a true Pagurus but belonged among the trichobranchiate forms.

Northern California, Nitkasund, Kadiak Is., Atcha, Kamtschatka (Brandt); lon. $33^{\circ} 55^{\prime} 30^{\prime \prime} \mathrm{N}$.; lat. $119^{\circ}$ $53^{\prime} 30^{\prime \prime}$ W.; 19 fathoms!

This species affords one of those curious cases of commensalism with colonies of hydroids sometimes found among deep sea pagurids. The colony of hydroids covering the shell in which the crab lives forms a membranous growth which extends beyond the boundary of the shell and, in course of time, according to Mr. Benedict, causes the shell to disappear, leaving its inhabitant with a membranous, instead of a calcareous domicile. In the specimen which I have, the covering is partly formed by the tip of a broken shell, but mainly by an extension of the membranous growth formed by the colony of hydroids. 'This arrangement certainly affords the crab the advantage of allowing it to grow, without its having to undergo the troublesome experience of changing its lodgings. (molme.s) 


\section{Subtribe THALASSINIDEA.}

Carapace short, compressed, and marked with two longitudinal sutures. Rostrum small or wanting. Both pairs of autenure elongated and furnished with long peduncles, those of the onter pair five-jointed and usually devoid of an acicle. First pereopods more or less chelate; second pair often chelate; third pair always simple. Last segment of the thorax movable. Abdomen long, the segments not overlapping, the side plates feebly developed. Tail-fin well developed. Branchiæ variable.

\section{Family CALLIANASSIDÆ.}

Carapace strongly compressed. Rostrum flattened. Eyes small. First pair of chelipeds generally unequal; second, pair with or without chelæ. Side plates of the abdomen absent. Telson and uropods broad and devoid of cross furrows. Burrowing crustaceans with soft, elongated bodies.

\section{Genus Upogebia Leach.}

Rostrum short and tridentate. Eyes small, with cylindrical peduncles. No antennal scale. External maxillipeds pediform. First thoracic legs subequal and subchelate, the pollex small; the remaining pairs not chelate. Abdomen long, with subquadrate joints; pleopods broad, the second pair similar to the others; uropods broad and foliaceous; telson broad, subquadrate, foliaceous. Podobranchiæ and mastigobranchiæ wanting.

Type.-U. stellata (MostaGo).

\section{Upogebia pugettensis (Dana).}

Gebia pugettensis Daxa, Proc. Acad. Nat. Sci. Phila., 1852, p. 19; Crust. U. S. Expl. Expd., Part I, 1852, p. 510, Pl. XXXII, fig. 1. Stimpson, Journ. Bost. Soc Nat. Hist., Vol. VI, 1857, p. 488, Pl. XXI, fig. 2. Lockingtox, Ann. Nat. Hist. (5), Vol. II, 1878, p. 299.

Gebia californica Stimpson, Proc. Cal. Acad. Sci., Vol. I, 1856, p. 88.

Upper portion of the carapace in front of the cervical groove flattened, scabrous, and hairy, and marked with three longitudinal grooves, the median groove being the shortest; front with the median tooth large, horizontal, triarigular, the lateral teeth short. A minute marginal tooth or spine-generally present a short distance below the lateral teeth. Anterolateral and postero-lateral angles rounded. Eye-stalks short, reaching very little further forward than the lateral teeth of the front. Antennules less 
than one-half the length of the antennæ, the flagella subequal. Peduncle of the antennæ exceeding that of the antennules; flagellum ciliated and longer than the carapace. Chelipeds equal; merus spinuloús and hairy below; carpus with the upper and lower edges spinulous, and having a spine at the antero-internal angle and another spine a short distance below it; hand with two parallel, scabrous, hairy lines on the upper edge and a transverse granulated line at the proximal end of the inner surface; a line of hairs on the outer surface which is continued obliquely across the carpus; lower side of the palm scabrous and hairy; pollex short, bent downwards, and having a tooth near the middle; dactyl obliquely compressed, incurved, acute, projecting, when closed, far beyond the tip of the pollex. Uropods short, the inner ramus distally rounded, truncated, the outer rounded. Telson entire, rectangular, wider than long.

Length, $112 \mathrm{~mm}$.

Queen Charlotte Is. (Smith); Vancouver's Is. (Bate); Puget Sound (Dana); Bodega Bay! San Francisco Bay! Monterey! Santa Catalina Is.! San Pedro! San Quentin Bay, Lower California (Lockington).

This species can generally be found wherever muddy beaches occur. It inhabits holes of one or more feet in depth, many of which are left uncovered at low tide, when the creatures can easily be dug out. Specimens are often taken, however, at a depth of several fathoms.

There is a peculiar parasitic crustacean, Phyllodurus abdominalis St., that is often found upon this species, being usually attached to the base of the abdominal appendages. Sometimes also a small bivalve molluse, Pythina rugifera, is found attached to this crustacean by its byssus.

The tooth on the pollex is sometimes absent, as it was in the specimen described by, Dana. "This tooth," says Stimpson, "is a prominent character in all the very numerous specimens in the Smithsonian Museum, but it is obsolete in the specimen described by Dana, although actual comparison shows them to be the same." In some small specimens from Catalina Island the small 
marginal spine beneath the lateral teeth of the front was absent, although they agreed with specimens from northern California in every other essential feature.

\section{Genus Callianassa Leach.}

Rostrum absent or reduced to a small point. Eye-peduncles flattened; cornea median, small or absent. Antennular flagella never shorter than the preceding joint. No antennal scale. External maxillipeds operculiform. First pair of pereopods very unequal and furnished with welldeveloped chelæ; second pair small and chelate; third pair with the pennltimate joint broadly expanded; fifth pair subchelate. Second pair of abdominal appendages in the female slender, the succeeding ones broad, foliaceous, and fringed with ciliated hairs. Caudal appendages wide. Gills with flattened filaments.

In this genus, according to Bate, only arthrobranchiæ are present, with the exception of a rudimentary masti. gobranchia on the third maxilliped.

\section{Callianassa californiensis Dana. Pl. II, f.27.}

Callianassa californiensis Dava, Proc. Acad. Nat. Sci. Phila., 1854, p. 175. Stimpson, Journ. Bost. Soc. Nat. Hist., Vol. VI, 1857, p. 489, Pl. XXI, fig. 4. A. Milne-Edwakds, Nouv. Archiv. Hist. Nat. Paris, Tome VI, 1870, p. 82. Lockington, Ann. Nat. Hist.(5), Vol. II, 1878, p. 301.

Callianassa occidentalis Strmpson, Proc. Cal. Acad. Sci., Vol. I, 1856, p. 88.

Front very short and rounded, with a small, triangular tooth on either side between the bases of the ocular peduncles and the antennæ. Ocular peduncles subtriangular, approximated at the bases, but diverging towards the acute tips which are somewhat upturned. Antennulary flagella subequal. Antennæ from one-half to two-thirds the length of the body, the peduncle nearly equalling that of the antennules. Chelipeds in the adult male with one arm enormously developed; ischium of the larger cheliped slender, compressed, incurved, distally widened, and finely denticulated on the acute lower margin; merus about as long as the ischium (generally a trifle longer) but stout, curved, smooth, almost naked except on the ciliated margins, and furuished with a prominent lobe at its infero-proximal angle; carpus very wide, a little longer than the merus, the outer surface smooth: naked, glossy, and evenly convex as if forming a part of the surface of a cylinder; margins acute, ciliated, and minutely serrulated; upper 
margin produced into a thin expansion overhanging the smooth inner surface; lower margin produced in a similar manner but not nearly so strongly; posterior margin below the articulation of the merus produced backwards into a broadly and evenly rounded lobe; hand narrower and a little shorter than the carpus, broadest at the base, with the ciliated margins more or less incurved towards the proximal end; a prominent hiatus between the fingers; a prominent upturned tooth between the bases of the fingers; fingers a little longer than the palm and furnished with tufts of cilia; dactyl longer than the pollex, minutely denticulated on the inner margin, and bent abruptly near the tip, forming a sharp hook. In the smaller cheliped the ischium resembles that of the larger one but is scarcely denticulated below; merus widest near the middle, shorter than the ischium, and devoid of the lobe at the base, but having an obsolescent tooth near the middle of the lower margin; carpus very long and narrow, with both surfaces convex; hand narrow, relatively much longer than the hand of the larger cheliped, but shorter than the carpus; palm oblong, the margins parallel, the fingers not gaping; dactyl longer than the pollex and not hooked at the tip. The smaller cheliped in the female is like that of the male but the larger cheliped is relatively smaller and of a different form; the ischium is like that of the smaller cheliped and the merus much the same but stouter and furnished with a more prominent inferior tooth; the carpus is similar in shape to that of the other cheliped but relatively shorter, scarcely one-half longer than broad, and but little longer than the merus; both surfaces convex, the margins not produced as in the male; hand as wide as the carpus, palm longer than broad, with the margins subparallel; fingers a little shorter than the palm; dactyl a little dilated near the base and curved at the tip. Ischium and merus of the ambulatory legs fringed with long hairs below; hand ovate, ciliated, much com. pressed, fingers longer than the palm. Candal appendages distally truncated. Telson scarcely shorter than the uropods and furnished with a rounded emargination at the tip.

Length of specimen, male, $61 \mathrm{~mm}$; length of larger cheliped, $50 \mathrm{~mm}$; of small cheliped, $32 \mathrm{~mm}$; width of carpus of large cheliped, $13 \mathrm{~mm}$; length of same, $155 \mathrm{~mm}$; length of hand to tip of dactyl, $10 \mathrm{~mm} . ;$ of merus, $12 \mathrm{~mm}$; of ischium, $10.5 \mathrm{~mm}$.. Length of larger cheliped of a female, $31 \mathrm{~mm}$; of smaller cheliped, $28 \mathrm{~mm}$.

California (Dana); Mutiny Bay, Alaska (Lockington); Puget Sound (Stimpson); Shoalwater Bay (Cooper); Bodega Bay! San Francisco Bay! Tomales Bay! Santa Barbara! San Pedro! 


\section{Callianassa longimana St. Pl. II, 28}

Callianassa longimana Stimpson, Proc. Bost. Soc. Nat. Hist., Vol. VI, 1857, p. 86; Journ. Bost. Soc. Nat. Hist., Vol. VI, 1857, p. 490, Pl. XXI, fig. 5. Cooper, Rep. Expl. and Sur. to Pacific Ocean, Vol. XII, Book 2, 1860, p. 388. BATE; in Lord's Nat. in Vancouver's Is., Vol. II, 1866, p. 279; Challenger Reports, Vol. XXIV, 1888, p. X9. A. Milve-Edwards, Nouv. Archiv. Hist. Nat. Paris, Tome VI, 1870, p. 83. Lockington, Anu. Nat. Hist. (5), Vol. II, 1878, p. 302.

Rostrum small but subacute, with two small, lateral teeth as in californiensis. Ocular peduncles and antennules much as in the preceding species. Antenure about one-half as long as the body. The chelipeds in the adult male are narrower than in californiensis; the ischium is of similar shape, with the lower margin finely denticulated and the outer surface more or less scabrous; merus similar to that of californiensis, but the upper margin is not convex and the lobe at the base is more prominent; carpus oblong, with the margins subparallel, ciliated, thin, but not produced nearly so much as in californiensis; outer surface smooth, glossy, and very convex; hand oblong, longer than the carpus, with thin, ciliated, parallel margins and a smooth, convex, glossy, outer surface; fingers shorter than the palm and furnished with tufts of cilia and not widely gaping when closed; the dactyl is dilated near the base, hooked at the tip, and projects but little beyond the pollex; upper edge and inner surface more or less granulated. The smaller cheliped resembles that of californiensis; merus widest near the middle, shorter than the ischium, often having a small tooth near the middle of the lower margin; carpus narrow, much longer than the ischium, convex and glossy on both sides, the margins parallel; hand of the same width as the carpus but scarcely as long; palm longer than broad; fingers long, ciliated and contiguous. The larger cheliped in the female is scarcely distinguishable from that of the female of californiensis. The smalier chelipeds are also very similar in the two species, but in longimana the hand and carpus are somewhat narrower. Ambulatory legs as in cailiforniensis. Telson with an obtuse emargination at the tip. Uropods distally truncated and slightly exceeding the telson.

Color whitish.

Length of a male specimen, $39 \mathrm{~mm}$; length of large cheliped, $39 \mathrm{~mm}$; ischium, $8 \mathrm{~mm}$.; merus, $8.5 \mathrm{~mm}$; carpus, $10.5 \mathrm{~mm}$.; hand, $13.5 \mathrm{~mm}$.; length of small cheliped, $22.5 \mathrm{~mm}$.; carpus, $6.5 \mathrm{~mm}$.; width of same, 2.1 mm.; length of merus, $4.2 \mathrm{~mm}$.; hand, $6.2 \mathrm{~mm}$.

Vancouver's Island (Bate); Shoalwater Bay (Cooper); Puget Sound (Stimpson); San Francisco Bay! San Pedro! 
San Diego! Santa Barbara Island! Santa Catalina Is.! San Quentin Bay, Lower California (Lockington).

It is remarkable that a species which resembles californiensis in almost all other respects should differ from it so markedly in the chelipeds of the adult male. The females are very much alike, but they can be distinguished by the differences in the rostrum and the relative stoutness of the smaller chelipeds.

\section{Callianassa gigas Dana.}

Callianassa gigas Dana, Proc. Acad. Nat. Sci. Phila., 1852, p. 19; Crust. U. S. Expl. Expd., Part I, 1852, p. 512, PI. XXXII, fig. 3. Sтimpson, Journ. Bost. Soc. Nat. Hist., Vol. VI, 1857, p. 489, Pl. XXI, fig. 3. A. Milne-Edwards, Nouv. Arch. Hist. Nat. Paris, Tome V1, 1870, p. 81. Lockington, Ann. Nat. Hist. (5), Vol. II, 1878, p. 302.

Front more or less triangular. Large hand strongly compressed and smooth; fingers similar, shorter than one-half the length of the hand and not gaping, the dactyl arcuate, acute; carpus more than one-half the length of the hand; merus narrow, toothed below at the base. Telson but little shorter than the uropods.

Length $4 \frac{1}{2}$ inches.

\section{Puget Sound (Dana).}

Callianassa affinis, sp. nov.

Male: Front obscurely tridentate. Ocular peduncles oblong, subacute, the inner margins not diverging toward the tip; cornea in front of the middle of the peduncle. Antennulary flagella subequal. Antennæ about one-half the length of the body. Ischium of the larger cheliped dentate below; merus stout, with a prominent lobe on the under side near the base, the lower side of which is denticulated; carpus short, with the postero-inferior angle broadly rounded and the margin not produced as it is in californiensis; hand fully twice the length of the carpus; palm oblong, both inner and outer faces convex; dactyl longer than the pollex, the extremity hooked and the inner margin furnished with a few stout teeth. Smaller cheliped slender; merus widest at the middle; carpus narrow, as long as the hand; fingers pubescent. First pair of ambulatory legs ciliated below. Telson broadly rounded and shorter than the uropods.

Point Loma, Calif.! San Clemente Is.! July, 1895. Collection University of California. 


\section{Subtribe HOMARIDEA.}

Carapace not strongly compressed and furnished with a more or less flattened rostrum. Antennal acicle present. First three pairs of pereopods chelate, the first pair large; last five pairs of pereopods with seven joints. Abdomen rather wide, the segments overlapping and laterally produced. Tail-fin well developed.

\section{Family ASTACID Æ.}

Carapace subcylindrical; rostrum well developed. Fifth thoracic segment movable. First abdominal segment in the male (and generally also in the female) furnished with sexual appendages. Telson and the outer branch of the uropods divided by a cross furrow.

Terrestrial or fresh water species confined to the northern hemisphere.

\section{Genus Astacus Fabr.}

This genus is distinguished from Cambarus chiefly by the possession of a pleurobranchia on the last thoracic segment. The Astacidø west of the Rocky Mountains belong, without exception, to the genus Astacus, while the numerous species inhabiting the Mississippi valley and the eastern states belong to the closely allied genus Cambarus.

\section{Astacus klamathensis St.}

Astacus klamathensis Strmpsor, Proc. Bost. Soc. Nat. Hist., Vol. VI, 1857, p. 87; Journ. Bost. Soc. Nat. Hist., Vol. VI, 1857, p. 494. Bate in Lord's Nat. in Vancouver's Iś., Vol. II, 1866, p. 278. HAGEN, Ill. Cat. Mus. Comp. Zool. Harvard Coll., No. 3, 1870, p. 93, Pl. III, fig. 169. Lockington, Ann. Nat. Hist. (5). Vol. II, 1878, p. 303. Faxon, Proc. Amer: Acad. Arts and Sci., Vol. XX, 1884, p. 151; Mem. Mus. Comp. Zool. Harvard Coll., Vol. X, No. 4, 1885, p. 131, Pl. VI, figs. 1 and 2; Proc. U.S. Nat. Mus., Vol. VIII, 1885, p. 356; Ibid., Vol. XII, 1890, p. 634; Ibid., Vol. XX, 1898, p. 665.

A rather small species with a smooth, punctated carapace. Rostrum not so long as in Trowbridgii, with the sides converging anteriorly and the dorsal surface concave and marked with an obscure median ridge; term. inal tooth acnminate and shorter than in Trowbridgii; lateral teeth acute or subacute and not produced into spines; a single spine on either side of 
the base of the rostrum, the posterior pair seen in Trowbridgii being absent. Dorsal area about twice as long as its width across the middle. Chelipeds much like those of Trowbridgii but there is no spine at the antero-internal angle of the carpus. Antero-lateral angles of the abdominal segments rounded; postero-lateral angles subacute.

Length, $95 \mathrm{~mm}$.

Klamath Lake! Sikon Creek; Des Chutes River; Walla Walla, Wenos Valley, Spokane Falls, Washington (Faxon); British Columbia in streams east of the Cascades (Bate); Eel River, Humboldt County, Calif.!

\section{Astacus Gambelii (Girard).}

Cambarus Gambelii GiraRd, Proc. Acad. Nat. Sci. Phila., 1852, p. 90; Ibid., 1853, p. 380.

Astacus Gambelii Agassiz, Proc. Acad. Nat. Sci. Phila., 1853, p. 375. Stimpson, Journ. Bost. Soc. Nat. Hist., Vol. VI, 1857, p. 492. HaGen, Ill. Cat. Mus. Comp. Zool. Harvard Coll., No. 3, 1870, p. 90, Pls. I, III, and XI. Lockington, Ann. Nat. Hist. (5), Vol. II, 1878, p. 303. FAXon, Proc. Amer. Acad. Arts and Sci., Vol. XX, 1884, p. 152; Mem. Mus. Comp. Zool. Harvard Coll., Vol. X, No. 4, 1885, p. 136; Proc. U. S. Nat. Mus., Vol. VIII, 1886, p. 356; Ibid., Vol. XX, 1898, p. 666.

Carapace obese, punctate. Rostrum short, acute, concave above, with the sides serrated and converging to the tip; a small spine on either side of the base behin.d which there may be a trace of a second pair. Dorsal area over twice as long as the width across the middle. Chelipeds large; merus much compressed, with the lower margins spinulous, the spine at the antero-internal angle small or absent; a spine on the upper side near the distal end; carpus devoid of spines, the upper edge with a longitudinal median depression; hands large, broad, scabrous, the upper surface of the palm thickly pilose on either side of the middle; lower side of the palm inflated.

Ogden River, Utah; Idaho; Mouth of Yellowstone River, Montana; Wyoming.

This species has been reported from California, but its occurrence there is not entirely certain. 


\section{Astacus Trowbridgii st.}

Astacus Trowbridgii Strmpson, Proc. Bost. Soc. Nat. Hist., Vol. VI, 1857, p. 87; Jouru. Bost. Soc. Nat. Hist., Vol. VI, 1857, p. 493. Cooper, Rept. Expl. and Sur. Pacific Ocean, Vol. XII, Book 2, 1860, p. 388. HAGEN, Ill. Cat. MIus. Comp. Zool. Harvard Coll., No. 3, 1870, p. 93, Pl. III, fig. 171, and Pl. X. FAxox, Proc. Amer. Acad. Arts and Sci., Vol. XX, 1884, p. 152; Mem. Mus. Comp. Zool. Harvard Coll., Vol. X, No. 4, 1S85, p. 134; Proc. U. S. Nat. Mus., Vol. VIII, 18s5. p. 356. Ibid., Vol. XX, 1S9S, p. 666 .

Carapace obese, punctate, nearly smooth, but roughened by minute prominences at the sides, and furnished with two pairs of spines at the base of the rostrum. Rostrum long, concave above, the sides very slightly converging anteriorly, each ending in an acute, upturned spine separated by a rounded notch from the long, slender, acuminate median spine which is also somewhat upturned. Antennules with a small spine on the lower side of the basal joint near the tip; peduncle shorter than the rostrum. Antennæx shorter than the body, with a strong spine on the outer side of the outer basal joint; acicie acuminate, nearly equaling the rostrum. Epistome triangular. Chelipeds long, but shorter than the body; merus compressed and armed below with a double series of spines, the outer series containing the less number; a strong spine at the infero-distal angle; a spine at the anterior end of the outer surface and another on the upper surface a little behind the anterior end; a spine at the antero-internal angle of the carpus and another on the anterior margin of the lower side; hands large, rough and punctate, with minute setæ in the punctures; fingers narrow, longer than the palm, irregularly dentated within, and spinulous toward the distal end of the outer margins; inner margin of the dactyl convex, the outer slightly concave. The lateral wings of the abdominal segments have the antero-distal angles rounded and the postero-distal angles subacute. Telson longer than broad, the terminal division nearly semicircular. Cardiac area wide.

Length of body, $141 \mathrm{~mm}$; of cheliped, $106 \mathrm{~mm}$; of hand, $54 \mathrm{~mm}$.

Columbia River, Oregon! Streams emptying into Shoalwater Bay (Cooper); Monterey (Faxon). The specimen from the latter locality was a large female "said to have been taken from a bunch of seaweed in salt water." 


\section{Astacus leniusculus Dana.}

Astacus leniusculus Dana, Proc. Acad. Nat. Sci. Phila., 1852, p. 20; Crust. U. S. Expl. Expd., Part I, 1852, p. 524, Pl. XXXIII, fig. 1. Stimpson, Journ. Bost. Soc. Nat. Hist., Vol. VI, 1857, p. 493. HAGEN, Ill. Cat. Mus. Comp. Zool. Harvard Coll., No. 3, 1870, p. 94. Lockington, Ann. Nat. Hist. (5), Vol. II, 1878, p. 304. Faxon, Proc. Amer. Acad. Arts and Sci., Vol. XX, 1884, p. 151; Mem. Mus. Comp. Zool. Harvard Coll., Vol. X, No. 4, 1885, p. 132, Pl. VI, fig. 4; Proc. U. S. Nat. Mus.,

Vol. VIII, 1886, p. 356. Ibid., Vol. XX, 1898, p. 666.

Closely allied to Trowbridgii. Carapace punctate. Rostrum trispinose, the median spine long and slender; $t$ wo pairs of spines at the base. Cardiac area rather wide. Carpus of the chelipeds unarmed with the exception of the antero-internal angle; merus denticulated and armed with a dorsal spine.

Length, 4 inches.

Columbia River (Dana); San Francisco County, Calif. (Faxon).

\section{Astacus nigrescens St.}

Astacus nigrescens Stimpson, Proc. Bost. Soc. Nat. Hist., Vol. VI, 1857, p. 87; Journ. Bost. Soc. Nat. Hist., Vol. VI, 1857, p. 492 . HAGEN, Ill. Cat. Mus. Comp. Zool. Harvard Coll., No. 3, 1870, p. 92, Pl. III. Lockington, Ann. Nat. Hist. (5), Vol. II, 1878, p. 303. Hoxley, The Crayfish, p. 244, fig. 62. Faxon, Proc. Amer. Acad. Arts and Sci., Vol. XX, 1884, p. 152; Mem. Mus. Comp. Zuol. Harvard Coll., Vol. X, No. 4, 1885, p. 135; Proc. U. S. Nat. Mus., Vol. VIII, 1886, p. 356; Ibid., Vol. XII, 1890, p. 634.

"Margins of the rostrum nearly parallel, denticulated with five or six small sharp spines on either side; the two anterior thoracic spines rather long. Dorsal area between the branchial regions as wide as in $A$. Gambellii, from which this species differs in its smaller and more slender hands, which are also without pubescence. The lateral angles of the abdominal segments are sharp, and the caudal segment has two slender spines on each side.

Color, blackish.

Length three inches."

Unalaska, Alaska; Fort Steilacoom, Washington; San Joaquin Slough, Coyote Creek, Santa Clara County; Alameda Creek, Alameda County, California (Faxon). 


\section{Astacus oreganus Randall.}

Astacus oreganus Randall, Journ. Acad. Nat. Sci. Phila., Vol. VIII, 1839, p. 13S, Pl. VII. DeKax, Zoology of New York, Part 6, Crustacea, 1844, p. 23. ErIchson, Wiegmann's Archiv. f. Naturg, (1), Bd. XII, 1846, p. 375. Strmpson, Journ. Bost. Soc. Nat. Hist., Vol. VI, 1857, p. 495. HAGes, Ill. Cat. Mus. Comp. Zool. Harvard Coll., No. 3, 1870, p. 95. Faxox, Mem. Mus. Comp. Zool. Harvard Coll., Vol. X, No. 4, 1885, p. 133.

Randall's description of this species is as follows:-

"Body fuscous, granulated, carpus with a sharp spine at the anterior angle; arm produced into a spine on each side anteriorly; thorax behind the front with five spines placed three before and one on each side behind the lateral ones; a large reddish spot on each side posteriorly; front little reflected on the sides, terminating in a long, slender spine and having a short, marginal spine on each side. Lon. $4^{\prime \prime}$. Testa granulata, bimaculata, fronte valde producta."

\section{Columbia River.}

Randall's specimen of this species has, unfortunately, been lost and nothing answering to his description has since been found. If the species belongs to the genus Astacus it differs from all the Astaci that are now known in the possession of a median thoracic spine. The figure accompanying Randall's description is so obviously inaccurate that it has no scientific value whatever. Dr. Hagen suggests that oreganus may be the same as leniuscilus, as both species come from the same locality. Faxon considers the species indeterminate.

The species described by Randall as Nephrops occidentalis was doubtless wrongly reported, through an exchange of labels, from Western America, instead of the Sandwich Islands. Ortmann, who puts the species in the genus Enoplometopus unites with it $E$. pictus A. Milne-Edwards. ${ }^{1}$

I See Kingsler, Bull. Essex Inst., Vol. XIV, 1883, p. 131, PI. II, fig. 1, and Ortmann, Zool. Jabrb. Abth. f. Syst., Bd. X, 1897, p. 274. 


\section{Subtribe LORICATA.}

Body not strongly compressed and often depressed. Rostrum broad, short or absent. Outer antennæ devoid of an acicle, the first joint of the peduncle fused with the epistome. All of the pereopods six-jointed, and none of them chelate except the last pair which is sometimes subchelate in the female. First abdominal segment devoid of appendages in both sexes. Posterior portion of the telson and uropods flexible. Gills trichobranchiate.

\section{Genus Panulirus White.}

Carapace spiny. Ocular peduncles small, free. Upper portion of the antennular segment wide, nearly horizontal, fused with the carapace, the surface furnished with spines, the sides smooth where they are rubbed by the bases of the widely separated antennæ. Flagella of the antennules long. Rostrum absent. A pair of spines on the anterior margin of the carapace over the eyes. Epistome devoid of a longitudinal furrow. Fifth pereopods of the female subchelate.

Pfeffer discards the name Panulirus on account of its similarity to Palinurus, the former name being derived from the latter by simply transposing the position of some of the letters. This does not appear to me a sufficient reason for discarding a generic name.

\section{Panulirus interruptus (Randall).}

Palinurus interruptus Randall, Journ. Acad. Nat. Sci. Phila., Vol. VIII, 1839, p. 137. Gibbes, Proc. Amer. Ass. Adv. Sci., 1850, p. 194.

Panulirus interruptus Stimpson, Proc. Cal. Acad. Sci., Vol. I, 1856, p..88; Journ. Bost. Soc. Nat. Hist., Vol. VI, 1857, p. 491. Rathвоn, R., The Fisheries of the U. S., Sec. 1, 1884, p. 7s0, Pl. 320. Ortmann, Zool. Jahrb. Abth. f. Syst., Bd. X, 1897, p. 260.

Senex interruptus Ortmann, Zool. Jahrb. Abth. f. Syst., Bd. VI, 1892, p. 23.

Carapace subcylindrical and covered with short spines. Rostral horns subparallel, compressed, and curved forwards. Upper portion of the antennulary segment with two pairs of spines, the margins raised and polished. The peduncle of the antennules slightly exceeds that of the antennæ; first joint about as long as the next two; second joint about three-fourths as long as the third; flagella longer than the peduncle, the 
outer one setose on one side except near the base. Peduncle of the antennr armed with short, strong spines; flagellum spinulous, compressed at the base, and exceeding the body in length. Epistome with the truncated anterior end armed with five or more spines, the median and outermost spines the largest. Ambulatory legs smooth, pubescent distally, the coxa of the last pair armed with a pair of spines. Abdominal segments furnished with a pair of transverse dorsal setose sulci which do not meet in the middle line except on the sixth segment. Telson spinulous at the base.

Southern California to Mexico. This is the common "spiny lobster" of the markets.

$P$. gracilis Streets, which has been united with interruptus, differs from the latter, according to Ortmann who has examined the types of both species, in having no transverse sulci on the segments of the abdomen.

\section{Subtribe CARIDEA.}

Body generally laterally compressed, the integument usually of flexible corneous texture. Carapace not united to the epistome. Antennules with a three-jointed peduncle, usually furnished with an external basal spine and two or three flagella. Antennal scale generally well developed. External maxillipeds generally pediform. Either, both, or neither of the first two pairs of pereopods may be chelate, the three posterior pairs always simple. Abdomen long, the sides produced downwards. Caudal fin well dereloped. Gills phyllobranchiate.

The Caridea are divided by Bate into four groups:-

1. Crangoninea, with the characters of the single family Crangonidr.

2. Polycarpinea: Carpus of the second pereopods annulated, or divided into secondary joints. Four families, Nikidæ, Alpheidæ, Hippolytidæ, Pandalidæ:

3. Monocarpinea: Carpus of second pereopods undivided. This group is divided by Bate into eleven families, only two of which are represented in our limits, the Atyidæ and the Palæmonidæ.

4. Haplopodinea: All of the thoracic legs similar. Single family, Hectarthropidæ. 


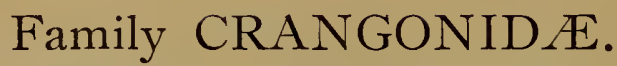

Mandibles slender, incurved, not divided at the apex, and devoid of a palp. External maxillipeds pediform. First pair of pereopods stouter than the second and subchelate, the dactyl closing against the margin of the hand, the pollex spiniform; second pair slender, simple or chelate, the carpus entire; all of the succeeding pairs simple.

\section{Genus Crangon Fabr.}

Rostrum very short and dorsally flattened. Eyes free. Antennules biflagellate. First pair of pereopods stouter than the second and but little longer. Third pair of pereopods slender, subequal to the first pair in length, and terminating in a styliform dactyl; the last two pairs are stouter than the third, and have long, more or less flattened dactyls. Branchiø five.

Type.-C. crangon (LiNs.).

\section{Crangon nigricauda St. Pl.II, f. 3)}

Crangon vulgaris Owen (non FABR.), Zool. Beechy's Voyage, 1839, p. 87. Dana, Crust. U. S. Expl. Expd., Part I, 1852, p. 536. Bate, in Lord's Nat. in Vancouver's Is., Vol. II, 1866, p. 278. Sмiтh, Rep. Prog. Geol. Sur. Canada, 1878-9, B, p. 212. Kingsley, Bull. Essex Inst., Vol. XIV, 1883, p. 129. Rathbun R., The Fisheries of the U. S., Sec. I, 1884, p. 817. Mordoch, Rep. Int. Polar Expd. to Pt. Barrow, Pt. IV, 1885, p. 138. Bate, Challenger Reports, Vol. XXIV, 1888, p. 485.

Crangon nigricauda Stimpson, Proc. Cal. Acad. Sci., Vol. I, 1856, p. 89; Journ. Bost. Soc. Nat. Hist., Vol. VI, 1857, p. 496, Pl. XXII, fig. 6. Streets and Kingsley, Bull. Essex Inst. Vol. IX, 1877, p. 108. Kingsley, Ibid., Vol. X, 1878, p.54. Lockington, Ibid., Vol. X, 1878, p. 159.

Crangon (Steiracrangon) nigricauda Kinahan, Trans. Roy. Irish Acad., Vol. XXIV, 1862, p. 57; Proc. Roy. Irish Acad., Vol. VIII, 1864, p. 68. Crangon alaskensis Lockington, Proc. Cal. Acad. Sci., Vol. VII, 1877, p.

34. Kingsley, Bull. Essex Inst., Vol. X, 1878, p. 54.

Crangon crangon affinis Ortuann, Proc. Acad. Nat. Sci. Phila., 1895, p. 180. Crangon vulgaris LinN., var. affinis DE HAAN, Walker, Trans. Liverpool

Biol. Soc., Vol. XII, 1898, p. 275.

Carapace with a spine on the gastric area and one on each hepatic region, the three situated in a transverse line. Rostrum short, grooved above, and rounded at the tip. Suborbital and antennal spines present, the latter the larger. Thoracic sternum furnished with a spine between the bases of 
the third pair of pereopods. The process on the onter side of the base of the antennules is broad, irregularly ovate, and about reaches the tip of the first joint; flagella louger than the peduncle, the inner one (and generally the outer) exceeding the tip of the antennal scale. Antennro as long as, or longer than the body; acicle about two-thirds the length of the carapace, with the antero-internal angle produced and rounded, extending as far forwards as (often further than) the spine at the outer angle. The external maxillipeds reach about as far forwards as the tip of the antennal scale. The first pair of chelipeds generally extend about as far forwards as the tips of the maxillipeds; merus with a spine near the middle of the lower side; hand oblong, about twice as long as wide, with the edges subparallel; the margin against which the finger closes is regularly convex and more nearly transverse than longitudinal; spinous pollex directed obliquely forwards. Third pair of pereopods slender and a little longer than the second. Antepenultimate abdominal segment carinated above; the sixth segment shows a tendency to become carinated and often has a slight median groove. Telson grooved above, subacute at the tip, and exceeding the sixth plus one-half of the fifth abdominal segment. Uropods narrow, rounded at the tip, and equalling (commonly slightly exceeding) the telson. An acute tooth on the sixth segment on either side of the base of the telson and a spine at the posterior inferior angles, between which there is a median ventral spine which is curved backwards; the posterior three-fourths or more of the ventral surface of this segment is marked by a groove.

Color in life dark gray with a blackish tail.

\section{Alaska to Lower California.}

This species differs from $C$. crangon of the Atlantic in having the fifth and sixth abdominal segments carinated above and in the groove on the under side of the sixth segment. It is also distinct from $C$. affinis. Affinis has a longer rostrum, a much narrower antennal scale, a much narrower and more acute telson. In the specimen of affinis figured by Bate ${ }^{1}$ the distal end of the hand is concave and is furnished with a tooth next to the pollex. The corresponding portion of the hand in nigricauda is evenly convex.

I have examined the types of Lockington's Crangon alaskensis.

\footnotetext{
1 Challenger Reports, Vol. XXIV, F1. LXXXVI, fg. 1.
} 


\section{Crangon franciscorum St.}

Crangon franciscorum Stimpson, Proc. Cal. Acad. Sci., Vol. I, 1856, p. 89; Journ. Bost. Soc. Nat. Hist., Vol. VI, 1857, p. 495, PI. XXII, fig. 5. Kinahan, Trans. Roy. Irish Acad., Vol. XXIV, 1862, p. 47; Proc. Roy. Irish Acad., Vol. VIII, 1864, p. 68. Cooper, Rep. Expl. and Sur. Pac. Ocean, Vol. XII, Book 2, 1860, p. 388. KingsLeY, Bull. Essex Inst., Vol. IX, 1877, p. 54; Ibid., Vol. XIV, 1883, p. 129, Pl. I, fig. 7. RathBUN R., The Fisheries of the U.S., Sec. I, 1S86, p.818. Sharp, Proc. Acad. Nat. Sci. Phila., 1893, p. 125. Ortmann, Ibid., 1895, p. 181.

Near nigricauda but more slender; the number and position of the thoracic spines are the same as in that species and the rostrum has almost the same form. Flagella of the antennules markedly unequal, the inner much exceeding, the outer not reaching the tip of the acicle. The antennær nearly equal, or slightly exceed the length of the body; acicle narrow, about three-fourths the length of the carapace, with the antero-internal angle rounded and not produced beyond the spine at the outer angle. Maxillipeds scarcely reaching so far forwards as the tip of the acicle. Chelipeds more slender than in nigricauda; merus with a spine near the middle of the lower side; hand narrowly oblong, mort than three times as long as broad, slightly wider and more inflated near the base; the margin against which the finger closes long, convex, and nearly longitudinal; the spinous pollex projects nearly transversely. The remaining pairs of legs similar to those of nigricauda. A well developed sternal spine. Antepenultimate abdominal segment rounded above, not at all carinated, with a pair of small spines at the posterior margin at the superolateral angles; sixth segment rounded, and devoid of a carina or groove above, sulcate below, with the spines at the posterior end the same in number and position as in the preceding species. Telson rounded, not grooved above, and tapering to an acute tip. Uropods as in nigricauda, generally slightly exceeding the telson.

Color "dark and light yellowish gray mottled. Eyes salmon-colored in life."

Length, $54 \mathrm{~mm}$; length of cheliped, $18 \mathrm{~mm}$; of hand, $8 \mathrm{~mm}$; of antennal scale, $11 \mathrm{~mm}$; of carapace, $14.5 \mathrm{~mm}$.; width of hand, $2 \mathrm{~mm}$.

Puget Sound; Shoalwater Bay (Cooper); Tomales Bay and Monterey (Stimpson); San Francisco Bay (Stimpson)!

This shrimp is very common in San Francisco Bay, where it is caught in large quantities for the markets. 


\section{Crangon nigromaculata Lock. \\ Pl.II, 32 .}

Crangon nigromaculata Lock INGTon, Proc. Cal. Acad. Sci., Vol. VII, 1877, p. 34 .

Crangon nigricauda Streets and Kingsley, Bull. Essex Inst., Vol. IX, 1877, p. 108. KingsLey, Bull. Essex Inst., Vol. X, 1878, p. 54. Lockington, Ibid., Vol. X, 1878, p. 159.

Crangon vulgaris Sмrтh, Rep. Prog. Geol. Sur. Canada, 1878-9, B, p. 212. Kivgsley, Bull. Essex Inst., Vol. XIV, 1882, p. 129.

Crangon crangon affinis Ortmane, Proc. Acad. Nat. Sci. Phila., 1895, p. 180. lat

Closely allied to nigricauda, but possessing the following distinguishing marks. It attains a considerably larger size, the rostrum is generally more nearly acute; the antennal scale is narrower and longer, being threefourths the length of the carapace and subequal to the telson; the hand is a little longer, with the anterior margin more nearly transverse; the antepenultimate abdominal segment is rounded (not carinated) above; the telson is acute at the tip, rounded above, and equaling (often slightly exceeding) the uropods, which are narrower than in nigricauda. The most characteristic and striking mark on this species is a large, colored spot on each side of the sixth abdominal segment. This spot has a bluish center surrounded by a black ring, outside of which is another ring of a yellowish color. The sides of the preceding abdominal segments are marked with small, yellow spots.) The chelipeds generally reach but little beyond the middle of the antennal acicle. In none of the specimens examined did they reach to the tip. With the exception of these differences this species agrees with nigricauda in all the characters mentioned in describing that form.

Although this species was regarded as a "color variety" of nigricauda by Kingsley and subsequently ranked as a synonym of that species by its own author, ${ }^{1}$ I am convinced that it should be restored to its rank as a distinct species. I have collected large numbers of nigricauda and nigromaculata from various localities on the coast of California, and have compared numerous specimens of both sexes and of all ages with considerable care. The large color mark on the sixth abdominal segment appears to be an absolutely constant character;

1 Bull. Essex Inst., Vol, X, p. 159. 
there is nothing corresponding to it or approaching it in any specimen of nigricauda I have seen. Both species are often brought up in the same dredge load and they can easily be separated at sight. The two species occur side by side from northern to Lower California without any notable approach to intergradation.

\section{Crangon alba, sp. nov.}

Closely allied to nigricauda, from which it differs in the following points: The antennal acicle is more narrowed at the tip and the membranous portion does not project forward. Hand slightly wider in the middle. The fifth and sixth segments of the abdomen are evenly rounded above and not at all crested. The lower side of the sixth abdominal segment is not grooved. The telson is evenly rounded above and devoid of a sulcus.

Color nearly white.

Dredged at Monterey, November, 1895. Collection University of California.

\section{Crangon stylirostris, sp. nov. \\ Pl. If, f. $33-35$}

Resembling nigricauda, with the spines on the thorax the same in num. ber and position, with the exception that there is no trace of a spine on the gastric area. Body stouter than in franciscorum. The rostrum is longer than in nigricauda, narrow, grooved above and tapering to a slender, acute tip, which is curved strongly downwards and much compressed laterally. The antennular peduncle does not reach so far forward as the middle of the antennal scale, the process on the outer side of the basal joint similar to that of nigricauda; the second joint of the peduncle is broader than long and much shorter on the outer than on the inner side; inner flagellum longer (but not one-half longer) than the outer, which about equals or a little exceeds the tip of the acicle. Antenno shorter than the body; acicle about two-thirds the length of the carapace and narrow at the distal end, with the antero-internal angle not at all produced. The external maxillipeds reach nearly to the tip of the antennal scale. The anterior chelipeds closely resemble those of nigricauda; a spine near the middle of the under side of the merus; hand oblong, about twice as long as wide, slightly widened distally, with the distal margin convex and oblique; spinous pollex oblique; finger fitting closely against the margin when closed. Second pair of pereopods more slender and a little longer than the thrrd; last two pairs subequal. Sternal spine well 
developed. Fifth abdominal segment evenly rounded above, having no trace of a carina; sixth segment rounded above, neither grooved or carinated, with the spines at the posterior end the same in number and position as in nigricauda, and with no groove on the lower side. Telson short, about equaling the length of the preceding segment and scarcely more than one-half the length of the carapace, the upper surface rounded (not grooved), the tip somewhat obtuse. The uropods are similar to those of nigricauda and extend considerably beyond the tip of the telson. Each of the abdominal segments in the male bears a median spine on the ventral side.

Length, $55 \mathrm{~mm}$.; length of carapace, $15 \mathrm{~mm}$; of antennal acicle, $10 \mathrm{~mm}$.; of telson, $8 \mathrm{~mm}$; of sixth abdominal segment, $7.5 \mathrm{~mm}$.

Two specimens, male and female, dredged at Trinidad, Humboldt County, Calif., together with numerous specimens of nigricauda.

Easily distinguished from the other species on the coast by the absence of a median thoracic spine, the short telson, and the acute rostrum. Collection University of California.

\section{Crangon munitus (Dana).}

Crangon munitus Dara, Proc. Acad. Nat. Sci. Phila., 1852, p. 20; Crust. U. S. Expl. Expd., Part 1, 1852, p. 536, Pl. XXXIII, fig. 5. Sтimpson, Journ. Bost. Soc. Nat. Hist., Vol. VI, 1857, p. 497. Kingsley, Bull. Essex Inst., Vol. X, 1878, p. 54; WALkER, Trans. Liverpool Biol. Soc., Vol. XII, 1898, p. 275.

Crangon (Sclerocrangon) munitus ORtmann, Proc. Acad. Nat. Sci. Phila., 1895, p. 179.

Abdomen not sculptured. Carapace seven-carinate, the median carina armed with two small spines. Lateral keels of the carapace smooth and, excepting the second from the median carina, ending in front in spines. Epimera of the abdominal segments without spinules.

Puget Sound (Dana).

I have examined the specimens from Magdalena Bay, Lower California, which Lockington ${ }^{1}$ has identified with munitus, and cannot agree with him in referring them to that species.

${ }^{1}$ Bull. Essex Inst., Vol. X, p. 159. 


\section{Crangon munitellus Walker.}

Crangon munitellus WALKER, Trans. Liverpool Biol. Soc., Vol. XII, 1898, p. 275, Pl. XVI, fig. 1 .

Body stout. Rostrum concave above and rounded at the tip. Carapace with a median carina with two teeth, and two short, parallel carinæ on either side terminating anteriorly in a tooth. Antennal acicle short and broad, with a strong central rib. Abdomen abruptly contracted at the fourth segment; "sixth segment darker colored than the others; a dark, transverse band on the caudal appendages.

"Length $25 \mathrm{~mm}$."

"Near C. munitus Dana, but differs in its much smaller size and in the second carina from the median terminating in a tooth half-way to the orbital margin, while in C. munitus it reaches the margin and has no tooth."

Puget Sound.

\section{Genus Paracrangon Dana.}

Rostrum elongate; eyes free. Second pair of pereopods wholly absent; fourth and fifth pairs acuminate, gressorial.

Type.-P. echinatus Dana.

\section{Paracrangon echinatus Dana. Pl.II. F. $36+3 \%$}

Paracrangon echinatus DANA, Proc. Acad. Nat. Sci. Phila., 1852, p. 20,; Crust. U. S. Expl. Expd., Part 1, 1852, p. 538, Pl. XXXIII, fig. 6. Stimpson, Jourr. Bost. Soc. Nat. Hist., Vol. VI, 1857, p. 497 . KingsLey, Bull. Essex Inst., Vol. X, 1878, p. 55. Whiteaves, Can. Nat. (2), Vol. VIII, 1878, p. 471. Sмiтh, Rep. Prog. Geol. Sur. Canada, 1878-9, B, p. 212. FAXon, Mem. Mus. Comp. Zool. Harvard Coll., Vol. XVIII, 1895, p. 131. Ortmann, Proc. Acad. Nat. Sci. Phila., 1895, p. 189.

"Beak elongate, obliquely porrect, bidentate at apex, unidentate above near middle, at base below in front a long curved spine. Carapax multispinous, along middle of back unequally four-toothed, either side 5-7 spinous. Abdomen above partly keeled, somewhat sculptured, sides acute. Hand elongate, immovable finger long and very slender. Fourth and fifth pairs of legs nearly naked, subequal.

Length of body, one and three-fourths inches. Length of beak half as long as carapax or rather longer than the line of it along the back. The 
exterior maxillipeds are very slender and short hairy. The fourth abdominal segment has a tooth and inside of it an emargination either side of middle, and the fifth is nearly similar."

Puget Sound, Oregon, obtained by dredging (Dana). Campbell Is. (Whiteaves); Vancouver's Is. (Smith); California and Japan (Faxon, Miers).

\section{Genus Sclerocrangon Sars.}

Carapace sculptured and armed with spines in the median line. Rostrum securiform, expanded below. First chelipeds stout; second pair slender, elongated, with a narrow hand and short dactyls. Abdomen generally sculptured and carinated above.

Type. $-S$. boreas (PHIPPS).

\section{Sclerocrangon boreas (Phipps).}

Cancer boreas PhIPps, Voyage North Pole, 1774, p. 190, PI XII, fig. 1.

Cancer homaroides Fabr. O., Fauna Grœnlandica, 1780, p. 24l; Mohr. Isl. Naturh. 1786, p. 108, No. 245, Pl. V.

Crangon boreas Fabr., Syst. Ent. Suppl., p. 409. Sabine, Appendix to Parry's 1st Voyage, No. 10, 1821, p. 57. Ross and Owes, Crust. in Appendix to Ross' 2nd Voyage, 1835, p. Ixxxi.

Cheraphilus boreas Kinahax, Proc. Roy. Irish Acad., Vol. VIII, 1864, p. 68. Miers, Ann Nat. Hist. (4), Vol. XX, 1877, p. 57. Murdoch, Rep. Int. Polar Expd. to Pt. Barrow, 1885, p. 139.

Sclerocrangon boreas SARS, Den Norske Nordhars-Expedition, VI, Zoologi, Crust., Part 1, p. 15. Stebing, Crustacea, p. 228 . ORtMANr, Zool. Jahrb. Abth. f. Syst, Bd. V, 1890, p. 532.

Crangon (Sclerocrangon) boreas Ortmanr, Proc. Acad. Nat. Sci. Phila., 1895, p. 178.

Carapace with three spines on the dorsal carina; a toothed carina on the branchial regions. Rostrum triangular, acnte. Abdomen sculptured, the anterior segments with a median dorsal carina, the sixth segment with a donble carina with a sulcus between the ridges. Epimera of the abdominal segments with only one spine each. Telson sulcate.

Arctic Europe and America, Labrador, Alaska, Siberia, "California," (Ross and Owen 1. c.). 


\section{Genus Nectocrangon Brandt.}

Rostrum wanting. Eyes hidden by the carapace. Second pair of pereopods chelate; dactyls of the last two pairs dilated and fitted for swimming. Branchiæ five on each side; none on the second maxilliped.

Type. $N$. lar (OweN).

\section{Nectocrangon lar (Owen).}

Crangon lar Owen, Zool. Beechy's Voyage, 1839, p. 88, PI. XXVIII, fig. I. Argis lar Kröyer, Nat. Hist. Tidskr., IV, 1842-3, p. 255, Pl. V, figs. 45-62.

Nectocrangon lar Bkandt, in Middendorff's Siberische Reise, Bd. II, Th. 1, 1851, p. 115. Strmpson, Proc. Acad. Nat. Sci. Phila., 1860, p. 25; Ann. N. Y. Lyc. Nat. Hist., Vol. X, 1873, p. 125. KInGSuey, Bull. Essex Inst., Vol. X, 1879, p. 55. Surth, Rep. Prog. Geol. Sur. Canada, 1878-9, B, p. 212; Trans. Conn. Acad., Vol. V, 1879, p. 61. Mordoch, Rep. Int. Polar Expd. to Pt. Barrow, 1885, p. 139. Ortmann, Proc. Acad. Nat. Sci. Phila., 1895, p. 181.

Median carina of the carapace armed with two spines behind the one at the anterior end. First five abdominal segments with a median dorsal carina, that of the fifth segment ending behind in a tooth or spine; the two carinæ of the sixth segment end posteriorly in a small spine. Telson acute, the carinæ armed with two or three pairs of spines near the tip.

Circumpolar: Arctic Ocean (Owen, Stimpson); Greenland (Kröyer); Labrador, Nova Scotia, Vancouver's Island (Smith); Pt. Barrow (Murdoch).

Owen's statement, that in this species "the second joint of the superior antenna is dilated and spiniform externally" is an error. He mistook the first joint for the second; the second is cylindrical.

A specimen in the U. S. National Museum (No. 7889) from Alaska agrees very closely with several specimens I have seen from the Atlantic. The ridges on the carapace are a little plainer than in the Atlantic forms; the carinæ on the abdomen are a little less acute and have a more decided tendency to fade out behind; the carina. of the fifth segment ends behind in a tooth, but those of the sixth segment do not. In specimens from the North. 
Pacific (Station 3441 Albatross Collection) the carinæ of the first four abdominal segments fade out before reaching the posterior end, but that of the fifth segment ends behind in a tooth, and the two carinæ of the sixth segment terminate posteriorly in small, acute teeth. In specimens from Vancouver's Island, according to Professor Smith, "the dorsal carina on the third, fourth, and fifth segments of the abdomen is broad and rounded, or flattened, and scarcely reaches the posterior edges of the segments, and the two carinæ on the sixth segment are rounded and fade out in the same way before reaching the posterior extremity of the segment." All of the Pacific specimens I have seen of this species came from farther north than Vancouver's Island, and it is an interesting fact that they are intermediate in character, as in locality, between specimens from the Atlantic and the forms described by Professor Smith.

\section{Nectocrangon alaskensis Kingsley.}

Nectocrangon alaskensis KINGSLEY, Bull. Essex Inst., Vol. XIV, 1882, p. 128, Ortuann, Proc. Acad. Nat. Sci. Phila., 1895, p. 182.

Carapace with four equally spaced, median spines and a small tooth between the first spine at the anterior end and the second. Orbits elongated. Antennular peduncles reaching about to the middle of the acicle. The abdomen has no carina on the first four segments except a slight on $\theta$ on the anterior portion of the first; the fifth segment has a prominent carina, which ends behind in a spine. The two carinæ on the sixth segment end behind in a spine. Telson acute, with three pairs of spines near the tip.

Alaska (Kingsley); Station 3257 Albatross Collection, numerous specimens!

\section{Family NIKID $\mathbb{E}$}

Rostrum horizontal. Ocular peduncles free. Mandibles devoid of a cutting edge and palp. First pair of pereopods simple or chelate. Second pair chelate, longer than the first and more slender, the carpus multiarticulate. 


\section{Genus Hippolysmata Stimpson.}

Carapace furnished with an elongated, compressed, dentate rostrum which is nearly horizontal. Antennules furnished with two long flagella. Mandibles strongly incurved, devoid of a palp, the apex undivided. Maxillipeds elongated, furnished with an exognath, and an epipodite, the terminal joint slender. First four pairs of pereopods furnished with an epipodite; the first pair is a little stouter than the others and chelate, the hand oblong; second pair filiform, multiarticulate and chelate. Abdomen smooth above.

Type.-H. vittata Stimpson.

Kingsley in his Revision of the Genera of Crangonidæ, Atyidæ and Palæmonidæ ${ }^{1}$ states, in defining this genus, that the first four pairs of feet are provided with an exopodite. This is probably a clerical error, the word exopodite having been substituted for epipodite. Stimpson says in his definition of this genus: "Pedes 1 mi-4 ti epipodo instructi.".

\section{Hippolysmata californica $S^{2} t$. Pl. $\bar{t}, f .38$.}

Hippolysmata californica Stimpson, Proc. Chicago Acad. Sci., Vol. I, 1866, p. 48; Ann. N. Y. Lyc. Nat. Hist., Vol. X, 1873, p. 123. Kingslex, Bull. Essex Inst., Vol. X, 1878, p. 56.

Hippolyte lineata Lockington, Proc. Cal. Acad. Sci., Vol. VII, 1877, p. 35.

Sharp, Proc. Acad. Nat. Sci. Phila., 1893, p. 116.

Rostrum slender, strongly ridged on the sides, bent downwards near the base, about one-half as long as the carapace, scarcely exceeding the antepenultimate basal joint of the antennules; it is armed above with six or seven teeth, the last tooth situated at considerably more than the usual interval from the preceding one and at about the anterior third of the calapace; below the rostrum is armed with three teeth; a strong spine above and a smaller one below the base of the antenna on the anterior margin. The spine on the outer side of the basal joint of the antennules reaches about two-thirds as far as the tip; last joint of the peduncle nearly as long as the preceding one; flagella subequal and longer than the body. Antennal acicle elongated, exceeding the tip of the antennular peduncle, and wide at the tip, where it is transversely truncated or broadly rounded. External

1 Proc. Acad. Nat. Sci. Phila., 1879, p. 413.

2 See Proc. Acad. Nat. Sci. Phila,, 1860, p. 26. 
maxillipeds equalling or exceeding the tips of the antennal scale, the terminal joint elongated and spinulons at the tip. In the first chelipeds the hand is narrow, a little longer than the carpus; fingers about twothirds as long as the palm. Second pair of pereopods very long and slender; ischium stonter than the merus and about as long, and more or less annulated towards the tip; merus divided into something over twenty annulations; carpus about as long as the merns and ischium combined and divided into about thirty-two annulations; hand minute, oblong, the fingers scarcely as long as the palm. The three posterior pairs of pereopods are subequal in length, much longer than the first pair, but shorter than the second; merus joints stouter than the distal ones and armed with scattered spinules; propodi elongated, minntely spinulous below; dactyls very short and armed below with spines. Postero-lateral angle of the fifth abdominal segment acute; that of the fourth segment rounded. Telson subacute, much shorter than the uropods, and armed on the rounded dorsal surface with two pairs of spinules.

This beautiful species is /very conspicuously marked with longitudinal stripes of drab and red or reddish brown.

Length from tip of rostrum to tip of telson, $47 \mathrm{~mm}$.; length of carapace from tip of rostrum, $17 \mathrm{~mm}$; length of acicle, $9.5 \mathrm{~mm}$; of first pair of chelipeds, $15 \mathrm{~mm}$.; of second pair, $25 \mathrm{~mm}$.; of third pair, $22 \mathrm{~mm}$.; of telson, $7 \mathrm{~mm}$.

San Diego (Stimpson)! Santa Catalina Is. (Lockington)! San Pedro! Found in tide pools.

I have examined the type specimens of Lockington's Hippolyte lineata. They unquestionably belong to the above species.

\section{Family ALPHEID $Æ$.}

Rostrum small or absent. Eye-peduncles short and concealed beneath a projection of the frontal margin of the carapace. Mandibles deeply divided at the apex and furnished with a palp. First pair of pereopods chelate and larger than the second pair which is slender, chelate and has the carpus annulated. Telson broad and rounded.

\section{Genus Alpheus Fabr.}

Carapace compressed, rounded above. Rostrum short or absent. Eyes completely hidden beneath the carapace. Antenuules biflagellate. Mandibles stont, the apical process narrow, palp two- or three-jointed. 
Anterior chelipeds stout, often very unequal. Second pair filiform, carpus cylindrical, annulated, hands small.

Type.-A. rapax FABR.

Key to the Species of Alpheus.

Front with a rostrum.

A spine on the infero-distal angle of the merus of the dentipes

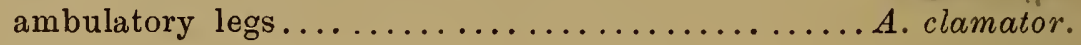

No meral spine.

No spine on the second basal antennal joint......... barbara.

A spine on the basal autennal joint.

Front trispinose.

Fingers of larger hand longitudinal; dactyl working nearly vertically........... equidactylus.

Fingers of large hand not longitudinal; dactyl short, curved, working horizontally...A. bellimanus.-

Front with but one spine............... californiensis.

Front devoid of a rostrum; dactyl joined to the lower side of the hand (Genus Betceus Dana).

Front emarginate in the center; hands oval............. cequalis.

Front not emarginate in the center; hands long and

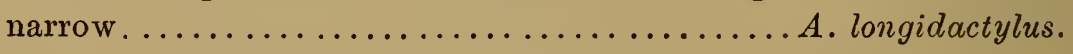

\section{Alpheus clamator Lock.} 位. II, $39 \forall 40$.

Alpheus clamator Lockington, Proc. Cal. Acad. Sci., Vol. VII, 1877, p. 43; Aun. Nat. Hist. (5), Vol. I, 1878, p. 469. KingsLey, Bull. Essex Inst., Vol. X, 1878, p. 58; Ibid., Vol. XIV, 1883, p. 117.

Alpheus transverso-dactylus KIngsLex, Bull. U.S. Geol. Sur., Vol. IV. No. 1, 1878, p. 196; Bull. Essex Inst., Vol. X, 1878, p. 58.

Alpheus candei Kingsley (not Guerin), Bull. Essex Inst., Vol. XIV, 1883, p. 124.

Front trispinose, the median spine short and separated by a deep sulcus from the small, acute, lateral spines which project nearly as far forward. Antero-lateral angle of the carapace devoid of a spine. Basal spine of the antennules broad, scarcely reaching the extremity of the first joint; second joint about twice as long as the third; outer branch of the flagellum much shorter than the inner one, the slender terminal portion shorter than the basal part; inner flagellum longer than the carapace. Second joint of the antenna with a spine below the articulation of the acicle; acicle narrow, nearly as long as the peduncle, with the outer side concave and ending in a strong spine which is separated by a deep, narrow cleft from the membranous inner portion; flagellum longer or shorter than the body. Maxillipeds about equaling the antennal peduncle. Chelipeds very unequal; 
merus of both trigonous, compressed, smooth, the upper surface edge ending abruptly, forming a sharp angle or tooth; carpus of smaller cheliped rounded, with a tooth at the anterior end of the upper side; carpus of the large cheliped very short, especially below, and devoid of teeth; large hand oblong, compressed, and greatly developed, being considerably larger than the thorax; proximal portion smooth and nearly naked, the distal portion deeply sculptured; a little in front of the middle of the palm the upper and lower edges are crossed by deep, transverse sulci, which are nearly opposite each other and are continued towards each other on the inner surface of the hand, their ends being separated by a shallow, longitudinal depression; the upper transverse sulcus is curved abruptly forwards a little external to the upper edge of the hand and joins a deep, transverse sulcus on the outer face behind the articulation of the finger; this last sulcus is continuous at its lower end with a longitudinal sulcus which ends near the middle of the palm; the transverse sulcus crossing the lower edge of the hand is curved abruptly forwards a little exterual to the lower mar. gin, forming a longitudinal sulcus which extends to the end of the pollex; this sulcus is separated from the longitudinal one above by a ridge which narrows distally and terminates in a curved spine or tooth just below the articulation of the dactyl and behind a short groove uniting the lower lougitudinal sulcus with the one above it; dactyl flattened, inclined down. wards, but working horizontally, the outer margin strongly convex, the inner concave near the thickened tip, but widened into a concave prominence near the base; the postero-external angle is flattened, forming a smooth surface which, when the finger is opened, abuts against a similarly flattened prominence behind it; pollex deeply grooved for the reception of the dactyl, ending below in a short, curred tooth. The small band is several times smaller than the larger one and not so deeply sculptured; the fingers are similar, longitudinal, and about as long as the palm, which is oblong and compressed; a small carina on the upper edge of the dactyl which does not reach the tip; a spine behind the articulation of the dactyl. Carpus of the second pair of legs five-jointed, the first two joints subequal, each 。 about as long as the fourth and fifth combined; third and fourth joints subequal, each shorter than the fifth; hand narrow, fingers slightly longer than the palm, which is subequal to the last joint of the carpus. The two following pairs stout, the merus large and armed with a spine near the infero-distal angle; carpus with a spine at the infero-distal angle and another further back; propodi with five or six spines below. Last pair of legs much less stout than the preceding pairs; merus and carpus devoid of a spine at the infero-distal angle; spines on the propodi feeble; dactyls of all the pairs short, curved, with a small spine behind the tip. Telson furnished above with a broad, shallow groove and two pairs of spinules.

Length of body, $31 \mathrm{~mm}$; of carapace, $11 \mathrm{~mm}$.; of large hand, $18 \mathrm{~mm}$; of small hand, $11 \mathrm{~mm}$. 
Farallon Is.! Monterey! Santa Barbara! San Pedro! San Diego! San Bartholome Bay, Lower California (Lockington).

Kingsley ${ }^{1}$ unites his Alpheus transverso-dactylus with A. candei Guerin from the Bermuda Islands and the West Indies, at the same time listing $A$. clamator Lock. as a distinct species. But as Kingsley's description of transverso-dactylus agrees perfectly with clamator, and as his specimens came from a locality where that species is abundant, there is no doubt in my mind that Kingsley's species is identical with the latter form. Having described as clamator ${ }^{2}$ what was really a distinct species, A. barbara Lock., Kingsley made out of specimens which really belonged to clamator a new species, transversodactylus. I am unable, moreover, to follow Kingsley when he subsequently unites his transverso-dactylus with A. candei. Candei, according to Guerin," "a la pièce basilaire des antennes externes prolongée en une longue pointe qui atteint la moité de la longeur de l'appendice lamelleaux," while in clamator this spine does not reach one-third the length of the acicle. In candei "les cuisses des troisieme et quadrieme pattes n'ont pas de dents," while in clamator both bear a prominent spinetooth. The rostrum is smaller in candei than in clamator, and there are differences in the form of the larger hand.

\section{Alpheus bellimanus Lock.

Alpheus bellimanus Lockington, Proc. Cal. Acad. Sci,, Vol. VII, 1877, p. 34; Ann. Nat. Hist. (5), Vol. I, 1878, p. 470. Krngsley, Bull. U. S. Geol. Sur., Vol. IV, No. 1, 1878, p. 199; Bull. Essex Inst., Vol. X, 1878 , p. 59; ibid., Vol. XIV, 1883, p. 111.

${ }^{3}$ Bull. Essex Inst., Vol. XJV, p. 124.

${ }^{2}$ Bull. U. S. Geol. Sur., Vol. IV, No. 1, p. 197.

${ }^{3}$ De Sagra's Hist. de Cuba; Crustacés, 1857, p. 50, Pl. II, figs. 9 and $9 a$. 
Allied to clamator. Front trispinose, the median spine the largest and not separated from the lateral spines by sulci. Antennules as in clamator; the acicle of the antemno about reaches the tip of the peduncle and is similar to that of clamator but the cleft between the spine and the inner portion is not so deep as in that species. Maxillipeds pubescent, reaching to the tip of the antennal pednncle. Chelipeds unequal, dissimilar; resembling those of clamator, but presenting the following differences: The transverse sulcus on the lower side of the larger hand is prolonged posteriorly on the inner side of the lower edge as a longitndinal sulcus, a feature not present in that species; there is no longitudinal sulcus on the inner surface of the hand separating the inner ends of the transverse sulci, and the upper, transverse sulcus is not so deep as in clamator. The smaller hand is sculptured much like the larger one but the sulci are not so deep, nor the ridges so prominent; the pollex is rather slender, a little shorter than the palm, and nearly longitudinal, curving a little downwards and having a ridge on the onter side a little above and parallel with the outer edge, the surface above which is somewhat excavated for the reception of the lower margin of the dactyl; dactyl contracted at the base but expanded a short distance beyond into a high, thin, rounded lamina, the plane of which is nearly vertical; the lower edge is nearly straight when seen from the side but curved when seen from below and ends in a short tooth which is curved downward and inward; its postero-external angle has a flattened projection which, when the finger is opened, abuts against a flattened projection of the palm as in the larger hand. Carpus of the second pair of legs fire-jointed, the first joint about as loug as the next two combined, second and fifth joints subequal and each about as long as the third and fourth together; hand narrow, fingers a little longer than the paim which is somewhat shorter than the last joint of the carpus. The two following pairs of legs not so stout as in clamator, neither the merus nor carpus with a spine at the infero-distal angle; propodi armed below with seren or eight pairs of spines; dactyls short, curved and devoid of a subterminal spine.

Length, $33 \mathrm{~mm}$; leugth of carapace, $12 \mathrm{~mm}$; of large hand, $17 \mathrm{~mm}$; of small hand, $13 \mathrm{~mm}$.

\section{Monterey; Santa Barbara! San Pedro! San Diego!}

\section{Alpheus barbara Lock.}

Alpheus clamator Kingsley (not Lockington), Bull. U. S. Geol. Sur., Vol. IV, No. 1, 1878, p. 197.

Alpheus barbara Lockisgtos, Ann. Nat. Hist. (5), Vol. I, 1878, p. 471. KingsLey, Bull. Essex Inst., Vol. XIV, 1883, p. 117.

I have seen no specimens of this species. It was described by Kingsley from a single imperfect specimen 
which he erroneously considered to belong to clamator Lock. Afterwards Lockington, perceiving that Kingsley's clamator was not true to name, rechristened the species A.barbara. The following is Kingsley's description:

"Basal spine of antennulæ stout, short, not reaching second join1 of peduncle; third joint half as long as preceding. Antennæ without spine on the basal joint. Antennal scale narrow, the spine at the anteroexterior angle acute, slender, reaching the end of the antennular peduncle. External maxillipeds rather broad, extending slightly beyoud the antennal scale. Feet of first pair unequal. Merus smooth, with a very slender spine on the distal portion above. Larger hand compressed, a constriction of each margin at about the middle, a spine above the articulation of the dactylus, behind which a sulcus runs obliquely across the superior margin. A second spine on the outside; thumb slender; dactylus compressed, semicircular in outline viewed from the side, slightly longer than the thumb. Smaller hand with both margins constricted; upper margin of palm tuberculate; a spine above the articulation of the dactylus; fingers about equal to the palm, completely closing. Ischium and merus of second pair equal; carpus five-jointed, first two joints equal, and each as long as the third and fourth, which are also equal; fifth joint nearly as long as the first. Merus joints of posterior pairs without spines; propodal joints spinulose beneath; dactyli slender. Santa Barbara, Cal. (W. G. W. Harford)."

\section{Alpheus californiensis, sp. nov.} Pl.II, f. $42, p l$. II, f. $43 \circ 44$.

Anterior portion of the carapace convex and furnished with a fine longitudinal line. Rostrum short, acute, continuous behind with a short cariua, which is separated from the ocular lobes on either side by a deep groove. Ocular lobes rounded in front and devoid of a tooth or spine. Antero-lateral angle of the carapace broadly rounded. Basal antennular spine broadly ovate, acuminate, and scarcely reaching the tip of the first joint of the peduncle; third joint of the peduncle less than half the length of the second; onter flagellum nearly oue-half as long as the iuner one, the slender, terminal part about one-half the length of the basal portion; inner flagellum about one-half the length of the body. Antennm about as long as the body; peduncle slightly exceeding that of the antenuules; a small spine on the infero-distal margin of the second basal joint; acicle not reaching the tip of the peduncle, outer margin slightly concave and terminating in a strong spine, which is separated from the membranous portion by a deep, narrow cleft. Maxillipeds somewhat exceeding the 
antenual peduucle. Anterior chelipeds very unequal; merus of both members compressed, and devoid of a spine at the supero-distal angle; carpus without a tooth or spine; hand of large cheliped large, oblong, compressed, upper and lower sides constricted near the middle, the upper constriction formed by a short, transverse groove a short distance behind the dactyl; pollex curved upwards and inwards at the tip and deeply excavated at the base for the reception of the dactyl; dactyl compressed, shorter than the palm, the outer margin strongly convex, the inner more or less concave and having a flattened process near the base which fits into the excaration in the pollex. Smaller hand long, narrow, pubescent, somewhat compressed and devoid of scuipturing; fingers narrow, straight, subequal to the palm, the tips hooked and crossing when closed. First joint of the carpus of the second pair of legs long, exceeding the second, which is about as long as the next $t$ wo combined; third and fourth joints subequal, each a little shorter than the fifth; hand shorter than the last two joints of the carpus. The two following pairs of legs are stouter than the last pair; merus devoid of a spine; propodi strongly spinose below. The sides of the first five abdominal segments are rounded. Telson broadly rounded at the tip and armed above with two pairs of spinules.

Length, $37 \mathrm{~mm}$; length of carapace, $12.5 \mathrm{~mm}$; of large hand, $15 \mathrm{~mm}$.; of small hand, $9 \mathrm{~mm}$.

San Pedro, Calif.; dredged in the harbor, July, 1895. Collection University of California.

\section{Alpheus equidactylus Lock. \\ Pl. III, $6.45+46$.}

Alpheus equidactylus Lockivgtos, Proc. Cal. Acad. Sci., Vol. VII, 1877, p. 35; Ann. Nat. Hist. (5), Tol. 1, 1878, p. 472. Kingsley, Bull. U. S. Geol. Sur., Vol. IV, No. 1, 1878, p. 199; Bull. Essex Inst., Vol. X, 187S, p. 59; Ibid., Vol. XIV, 1883, p. 111.

Carapace smooth, convex longitudinally on the upper side. Front trispinose, the median spine cousiderably larger than the lateral ones and not separated from them by sulci. Basal spine of the antenuules long, reaching vearly to the tip of the second joint of the peduncle; last two basal joints short and subequal; outer flagellum shorter than the more slender inner one, the slender part much longer than the basal portion. Second joint of the antenna with a spine below the acicle; acicle rather wide, longer than the peduncle. Maxillipeds sparingly pubescent and about reaching the tip of the antennal scale. Anterior chelipeds smooth, uaked, unequal, but of similar form; merus with the angles rounded and devoid of spines or teeth; carpus short, similar to that of the larger cheliped in clamator; hands oblong, narrow, compressed, smooth; a transverse sulcus crossing the upper edge of the hand behind the dactyl, from which a 
narrow, deep, longitudinal sulcus extends backwards on the upper edge in the larger hand almost to the posterior margin, but about two-thirds as far in the smaller one; fingers longitudinal, subequal (the dactyl slightly the longer), and working nearly vertically; pollex rather slender, tapering, the tip curved npwards and the inner margin armed near the base with two or three small teeth; dactyl, with one or two very small teeth near the base of the straight inner margin, the tip curved and crossing that of the pollex when closed; smaller hand more slender than the larger one, the fingers somewhat narrower, otherwise very similar. Carpus of the second pair of legs five-jointed, the first joint about as long as the four following ones combined, second, third and fourth joints subequal, the fifth a little longer; hand narrow, the fingers longer than the palm. Posterior pairs of legs slender; merus and carpus devoid of spines; dactyls with very slender tips. Sixth abdominal segment with a postero-lateral spine. Telson tapering, rounded above where it is furnished with two pairs of spinules, the tip rounded.

Length of body, $18 \mathrm{~mm}$; of carapace, $6.5 \mathrm{~mm}$; of larger hand, $7 \mathrm{~mm}$; of smaller hand, $5 \mathrm{~mm}$.

Monterey (Lockington)! Santa Barbara!

Mr. Kingsley has united $A$. equidactylus Lock. with A. heterochelis Say, ${ }^{1}$ probably on Lockington's authority, for he says: "Mr. Lockington informs me that his $A$. equidactylus, from Monterey, Cal., presents no appreciable differences from specimens of A. heterochelis, from Florida, that I sent him." There is evidently a mistake here, for heterochelis and equidactylus are so different that it is scarcely credible that they should be regarded as members of the same species by anyone who had carefully compared them. Lockington's species was described from a single, imperfect, dried specimen which had lost one of the anterior chelipeds, which Lockington in his later description of the same specimen was inclined, in opposition to his previous opinion, to regard as the larger member. Both hands in this species are elongated much like the smaller hand in heterochelis and, from a superficial comparison, Lockington probably concluded that his specimen was a

\footnotetext{
1 Proc. Acad. Nat. Sci. Phila., 1887, p. 329.
} 
heterochelis with the larger hand lost. The two species may, however, readily be distinguished aside from the great differences in the larger chelipeds, as heterochelis has no ocular spines, while in equidactylus the front is "trirostrate, without sulcus between rostrum and ocular spines" (Lockington). I have examined Lockington's type which has now lost both its hands.

\section{Alpheus (Betæus) æqualis (Lock.).}

\section{1 . II, \&u, 47,}

Betaus equimanus Lockisgton, Proc. Cal. Acad. Sci., Vol. VII, 1877, p. 43. Alpheus Harfordi Kingsuli, Bull. U. S. Geol. Sur., Vol. IV, No. 1, 1878, p. 198; Bull. Essex Inst., Vol. X, 1878, p. 58; Ibid. Vol. XIV, 1883, p. 124, Pl. II, tig. 4 .

Alpheus cequalis Krrgscer, Bull. U. S. Geol. Sur. Vol. IV, No. 1, 1878, p. 199.

Betaus aequalis Lockington, Ann. Nat. Hist. (5), Vol. I, 1878, p. 478.

Carapace moderately compressed, the dorsal side nearly straight. Front devoid of spines, emarginate in the middle and rounded in front of the eyes. Basal spine of the autennules long and slender, reaching beyond the middle of the secoud joint; second joint about twice the length of the third; the inner flagellum may exceed the length of the carapace; outer flagellum much shorter than the inner one, with the slender terminal portion subequal fo the basal part. Second joint of the antennæ with a spine below the articulation of the acicle; peduncle about equaling that of the antennules; scale narrowly oilong, nearly reaching the tip of the peduncle, the outer margin nearly straight and ending in a stroug spine which is separated by a deep, narrow cleft from the membranous portion; flagellum shorter than the body. Maxillipeds scarcely reaching the tip of the antemnal peduncle. Anterior chelipeds subequal; merus trigonous, com. pressed, scarcely more than twice as long as high; carpus devoid of a tooth or spine; hands oval, vertical, smooth, strongly compressed, and devoid of grooves or inequalities; dactyl slender, articulated on the lower side of the hand, and working vertically, the inner margin straight or somewhat concave near the base; pollex much wider than the dactyl; the entire inner margin may be straight, or there may be a deep, rounded notch near the base; tips of the fingers curved and crossed when closed; inner margins pubescent, the rest of the hand uaked. Carpus of the second pair of legs five-jointed, the first joint about as long as the three following ones com. bined, which are subequal and shorter than the fifth; hand narrow, palm nearly as long as the fingers or the last joint of the carpus. Posterior legs 
slender; dactyls short, with a subterminal spine. Postero-lateral angle of the sixth, abdominal segment acute, that of the two preceding segments subacute. Telson tapering, rounded at the tip, and armed on the convex dorsal surface with two pairs of spinules.

Color in life a dark purple.

Leugth of body, $19 \mathrm{~mm}$; of carapace, $6 \mathrm{~mm}$; of hand, $6 \mathrm{~mm}$.

Catalina Island (Lockington)! Santa Barbara (Kingsley); Point Arena!

This species is found under the mantle of the Abalone, Haliotis rufescens, but it is not confined to that habitat, for I found several specimens upon some seaurchins that were brought up from several feet of water at Catalina Island. Their color was a dark purple like the specimens described by Lockington and resembled the color of the sea-urchins in whose spines they were entangled when captured. At Point Arena I captured from under a rock at low tide a single specimen, which was nearly white.

\section{Alpheus (Betæus) longidactylus (Lock.).}

Betceus longidactylus Lockington, Proc. Cal. Acad. Sci., Vol. VII, 1877, p. 35; Ann. Nat. Hist. (5), Vol. I, 1878, p. 480.

Alpheus longidactylus Kingslex, Bull. U. S. Geol. Sur., Vol. IV, No. 1, 1878, p. 198; Bull. Essex Inst., Vol. X, 1878, p. 58; Ibid., Vol. XIV, 1883, p. 124.

Carapace quite strongly compressed and smooth, with no trace of a rostrum or ocular spines, and scarcely notched at the center. No spines or teeth on the anterior margin of the carapace. Basal spine of the antennules slender, elongated, about reaching the tip of the second joint; last two basal joints subequal; inner flagellum a little longer than the carapace, the outer one considerably shorter than the inner and contracted near the middle, the terminal portion slender. Antennæ with a spine at the inferodistal angle of the second basal joint; scale with a prominent terminal spine which nearly reaches the tip of the peduncle, the latter reaching about as far forward as the peduncle of the antennules. Maxillipeds nearly reaching the tip of the antennal peduncle. Chelipeds elongated, similar; merus with rounded angles, the distal end widened, the outer surface with a broad, oblique sulcus; a short, transverse groove at the 
supero-distal angle, behind which the upper margin ends abruptly bu+ does not terminate in a spine; the surface is granulated, the lower side granulo-spinulous; carpus short, rounded; hand large, oblong, compressed, scabrous, the margins rounded, the length much exceeding that of all the preceding joints combined; fingers slender, widely gaping, longer than the palm, the tips furnished with small, curved, corneous claws, which are crossed when the fingers are closed; pollex with a large tooth a littie behind the middle of the inner margin and a small, round tooth at the base. Carpus of the second pair of legs five-jointed, the first joint about as long as the three following ones combined; second, third, and fourth joints subequal, the tifth a little longer; hand oblong; fingers about as long as the palm, which is about one-half longer than wide and nearly as long as the last joint of the carpus. Postero-lateral angles of the fourth and fifth abdominal segments acute. Telson tapering, ronnded at the tip, with two pairs of spinules above. On the onter side of the distal end of the pednncle of the uropods there is a pair of prominent spines, behind which is a small third spine; a spine near the outer angle of the uropods. "Color of carapax of dried specimen green with nuances of russet and olive. The fingers of larger hand are light red, the tips green."

Length, $1.12 \mathrm{inch}$; length of larger hand, 0.56; of smaller hand, 0.36 .

San Diego (Lockington)! San Pedro!

This description is taken from Lockington's type specimen (No.96), which is preserved in the California Academy of Sciences. The specimen was dried and had lost most of its ambulatory legs. The unequal size of the chelipeds is exceptional.

Since writing the above description I have collected numerous specimens of this species at San Pedro, Calif., where it is found in abundance in tide pools on a rocky ledge near the entrance to the harbor. The hands are similar and generally equal and very much larger in adult males than in young males and females. The anterior margin of the carapace in some specimens is slightly convex, in others straight, while in a few it is slightly concave. In many adult females, and to a less extent in the adult males also, the dorsal surface of the carapace is bulged upwards, owing, doubtless, to the enlargement of the ovaries or testes. Many of the 
specimens were infested with a parasitic Isopod attached to the under side of the abdomen. The color varies in living specimens from olive green to olive brown; the legs are reddish, and in many specimens there is a light-colored dorsal stripe along the middle of the body. The specimens were taken June 25, 1895; most of the females were carrying ova.

\section{Family HIPPOLYTIDÆ.}

Rostrum generally prominent. Eyes not covered by the carapace. Mandibles with or without a cutting edge and palp. First pair of legs chelate and stouter than the second pair which is also chelate and has the carpus annulated.

The genera of this family need a thorough revision. The genus Hippolyte has long been a sort of receptacle for a large and somewhat miscellaneous assemblage of forms. Bate has instituted several new genera for many of the species but several more will doubtless be required. Most of the Pacific species of this family fall naturally into a group which I have characterized as the genus Heptacarpus.

\section{Genus Hippolyte Leach.}

Carapace produced into a laterally compressed, serrated rostrum which is excavated at the under side of the base. A supraorbital and antennal spine present. Ocular peduncles short. First joint of the antennular peduncle excavated above and armed with an external basal spine; second and third joints subcylindrical, the terminal one supporting two flagella, the outer of which is the shorter and more robust. Antennal scale with a spine at the distal end of the outer margin. Third maxillipeds with a short exognath and having the last joint armed with spinules at the tip. First pereopods short and stout with the carpus excavated at the extremity to receive the base of the hand. Second pair slender, a little longer than the first, and having the carpus three-jointed. The three following pairs of legs decrease slightly in length posteriorly; dactyls spinulous below. Abdomen smooth, the third segment posteriorly produced in the median dorsal line and somewhat arcuate. Branchiæ five.

Type.-H. varians LEACH. 
Bate's diagnosis of this genus was based on an examination of Leach's type specimens of varians. I have slightly modified Bate's description, as some of the species which Bate himself refers to Hippolyte contradict the characters of the genus as he defines it.

\section{Hippolyte californiensis Holmes.}

$$
\text { 기.2. fis } 38
$$

Hippolyte californiensis HoLıes, Proc. Cal. Acad. Sci. (2), Vol. IV, 1895, p. 576, figs. 21-26.

A long slender species. Rostrum sleuder, slightly upturned, a little longer than the carapace; upper margin armed with 3-5 teeth; lower margin with 4-5 teeth; base of the rostrum rounded and not continued upon the carapace. A supraorbital spine. Peduncle of the antennules about one-half as long as the rostrum; outer flagellum much shorter than the slender inner one, the last few joints much narrowed. First pair of chelipeds very short; hand broad and thick at the base, which fits into a depression in the carpus. Second pair of chelipeds more slender but much longer than the first pair; carpus three-jointed, the first joint the longest. Abdomen not crested or carinated. Telson truncated and spinulous at the tip.

Length, $38 \mathrm{~mm}$.

Bodega Bay, Calif., in the eel-grass! San Pedro! San Diego! Specimens from the last named locality are considerably smaller than those from Bodega Bay.

\section{Hippolyte Layi Owen.}

Hippolyte Layi Owes, Zool. Beechy's Voyage, 1839, p. 90, Pl. XXVII, fig. 3. BRA NDt, in Middendorff's Siberische Reise, Bd. II, Th. 1, 1851, p. 117. Stiupsox, Journ. Bost. Soc. Nat. Hist., Vol. VI, 1857, p. 499. Bate, in Lord's Nat. in Vancouver's Is., Vol. II, 1866, p. 279. KIngsLEY, Bull. Essex Inst., Vol. X, 1878, p. 62. Lockington, Ibid., 1878, p. 161.

I have seen no specimens which I can refer to $H$. Layi. Owen's short description of this species is as follows:

"Hip. rostro acuminato, supra multi-serrato, ante medium subtus quadri-serrato. Long. corp. unc. $2 \frac{1}{2}$. Color ruber."

A little more light on the subject is given in the discussion of the affin. ities of this species. "In addition to the difference in the serrations of 
the rostrum, which probably varies in different individuals of the same species (although the number was constant as above quoted in three specimens of each species which was preserved), Hip. Layi has a longer and narrower rostrum, extending to the extremity of the superior anten$\mathrm{n}$; the inferior seta of these antennæ is also proportionately longer. Hip. affinis has a spine above the eye, at the root of the rostrum, which is want. ing in the Hip. Layi; whilst this species has the fifth and sixth abdominal segments unispinous inferiorly on each side, Hip. affinis having the sixth segment only so armed.

"From the Alpheus Polaris of Sabine (Zool. Appendix to Parry's Voyage, p. 238, Pl. II, fig. 5) which is a Hippolyte of Leach, and from the species characterized by the latter author in the Malacostraca Podoph. Brit., the above species differ in the forms and proportions, as well as in the serrations of the rostrum."

Monterey (Owen); Vancouver's Island (Bate); Alaska (Lockington).

It is impossible to determine from Owen's description and figure in what genus this species belongs. It is certainly not a Hippolyte; it may be a Heptacarpus, but until more is known concerning it, it is best, I think, to leave its name unchanged.

\section{Hippolyte affinis Owen.}

Hippolyte affinis OwEN, Zool. Beechy's Voyage, 1839, p. 90, Pl. XXVII, fig. 4. BRaNdT, in Middendorff's Siberische Reise, Bd. II, Th. 1, 1851, p. 117. Stimpson, Journ. Bost. Soc. Nat. Hist., Vol. VI, 1857, 498. Kingsley, Bull. Essex Inst., Vol. X, 1878, p. 62.

Owen's short description of this species is as follows:

"Hip. rostro antennis superioribus breviore, supra multi-serrato, ante medium subtus sex-serrato. Long. corp. $1 \frac{1}{2}$. Color ruber."

Rostrum shorter than the antenuules, multi-serrate above, and armed below with six teeth in front of the middle. Length of the body $1 \frac{1}{2} \mathrm{inch}$. Color red.

Monterey (Owen).

There are several species of Hippolyte reported from Vancouver's Island by Professor Smith: viz., H. Gaimardii Milne-Edw.; H. Gronlandica, under which are 
included $H$. armatc and $H$. cornuta of Owen; H. Phippsii Kröyer, with which Smith unites $H$. turgida Kröyer, $H$. vibrans St. (o var.), and $H$. ochotensis Brandt; and $H$. spinus, which is now the type of Bate's genus Spirontocaris. All of these are circumpolar species, the western representatives of which I have not seen.

Another species of Hippolyte from Vancouver's Island has been described by Bate as H. esquimaltiana. It is not, however, a true Hippolyte, but the description is not sufficiently complete to enable one to determine just where it belongs. Hippolyte sitchensis Brandt has been reported from California by Stimpson, but a remark in Stimpson's description of $H$. picta discloses the fact that what he called sitchensis was probably another species. "Picta," says Stimpson, "differs from $H$. sitchensis in its longer external maxillipeds and non-carinated abdomen." It is certainly here implied that sitchensis has a carinated abdomen which, however, is not the case. Brandt in his description of that species says: "Annulus abdominis tertius facie dorsali ecarinatus," and further on that this species differs from $H$. gibba "durch den Mangel des Riickenkieles des dritten Bauchgürtels."

\section{Heptacarpus, gen. nor.}

Carapace carinated anteriorly and furnished with a dorsally serrated rostrum; the anterior margin is furnished with two spines, one just below the orbit, the other (generally the smaller) at the antero-lateral angle. No supraorbital spine. Ocular peduncles short, stout, single-jointed, and furnished with an ocellus on the posterior side. Antennules with a well developed onter basal spine; flagella two, a thick outer one terminating in a slender portion, and a slender (generally longer) inner one. Antennæ long, with a well developed scale, the outer margin of which ends in a spine. Maudibles strongly incurred, furnished with a slender apical process and a two-jointed palp. External maxillipeds deroid of an exognath. Anterior chelipeds stout, the carpus not excavated in front as in Hippolyte; hand oblong, the fiugers ending in small curved claws or hooks. Second pair of 
chelipeds filiform; carpus seven-jointed; hand small and narrow. Posterior legs of subequal length; carpus produced distally over the propodus; propodi and dactyls spinulous below. Telson tapering and armed above with several pairs of spines. Branchire five.

Type.-H. palpator (OweN).

Beside the characters mentioned in the diagnosis of the genus, all of the species I have seen agree in possessing the following features: There is a spine at the antero-external angle of the oblong first joint of the antennular peduncle and another spine on the lower margin of the inner side a short distance behind the distal end; the second joint of the peduncle has a spine on the outer side, and the third joint has a spine above the articulation of the thick flagellum, and there is generally a small spine above and internal to the articulation of the slender one. On the second joint of the antenna there is a blunt tooth above and a sharp spine below the outer edge of the scale. The tips of the external maxillipeds are armed with a circle of spines. The carpus of the anterior chelipeds has a short, transverse groove behind the inner distal margin.

\section{Heptacarpus palpator (Owen). Pl. III, f. $48+49$.}

Hippolyte palpator Owen, Zool. Beechy's Voyage, 1839, p. 89, Pl. XXVIII, fig. 3. Brandt in Middendorff's Siberische Reise, Bd. II, Th. 1, 1851, p. 117. Stimpson, Proc.' Cal. Acad. Sci., Vol. I, 1856, p. 89; Journ. Bost. Soc. Nat. Hist., Vol. VI, 1857, p. 499. Kingsley, Bull. Essex Inst., Vol. X, 1878, p. 62. Lockingtos, Ibid., Vol. X, 1878, p. 160.

? Hippolyte Hemphillii Lockington, Proc. Cal. Acad. Sci., Vol. VII, 1877, p. 35; Bull. Essex Inst., Vol. X, 1878, p. 160. Kingsley, Ibid., Vol. X, 1878, p. 63.

Rostrum slender, horizontal, considerably shorter than the carapace and armed above with six teeth, the last two (or three) of which are on the carapace; the lower margin may be devoid of teeth, or there may be a small tooth near the tip. The outer basal spine of the antennules reaches. nearly to the tip of the second joint of the peduncle; the upper distal margin of the first basal joint is armed with four spines, the spine at the 
outer angle being separated by a considerable interval from the other three which are close together. The spine above the articulation of the slender inner flagellum is very short; onter flagellum much shorter than the inner one. Antennal acicle tapering, longer than the telson; peduncle reaching about to the middle of the acicle which is in advance of the tip of the rostrum; flagellum often longer than the body: Mandibles with an oblong, thin, apical process which is armed at the distal end with several small teeth; palp two-jointed, about as long as the apical process behind which it normally lies. Maxillipeds very large, extending far beyond the tip of the antennal scale even in small specimens, while in adults the antepenultimate joint often reaches the tip of the acicle, the last joint extending beyond it for a distance greater than the length of the carapace; the outer margin of the antepenultimate joint is spinulous; last joint flattened, about four times the length of the preceding one and armed with a circle of spines at the tip and several smaller spines on the inner margin; there is a small epipodite but no exognath. Anterior chelipeds reaching considerably beyond the tip of the antennal scale; hand narrowly oblong. Second pair of chelipeds longer than the first; first joint of the carpus longer than the second; third joint longer than the first or fourth; fifth subequal to the fourth, longer than the sixth, which is much shorter than the seventh; hand about as long as the last three joints of the carpus. Posterior legs moderate, two or three spines on the outer side of the merus near the distal end; dactyls short, stout, about one-fourth the length of the propodi. Ail of the abdominal segments are rounded above; posterolateral angles of the fourth segment rounded or subacute, having a small spine-tooth; those of the fifth segment acute and ending in a spine. Telsou somewhat flattened above, where it bears four pairs of spinules; tip broadly rounded and furnished with a minute median spine between which and the spines at the outer angles there are on either side about four marginal setæ.

Monterey (Owen)! San Francisco Bay (Stimpson)! San Pedro! Santa Catalina Island! San Diego! Magdalena Bay (Lockingtơn).

Brandt refers some specimens from Alaska to this species. He says: "Wosnesenski brachte von der Insel Kadjak vier Exemplare einer Hippolyte mit die durch die langen, aüsseren Maxillarfüsse und mehrere andere Kennzeichen $H$. palpator ungemein ähneln. Ich möchte sie daher vorläufig zu ihr ziehen, obgleich, abweichend von palpator der Thorax derselben oben zwei-bis dreizähnig, der Stirnschuabel oben meist zwei-, zuweilen 
einzähnig, unten zahnlos und nur so lang wie die Augen erscheint, wahrend die inneren Antennen die Deckschuppen der aüssern Fuhler deutlich überragen. Die grössten Individuen messen von der Stirn zur Schwanzspitze 2", $4^{\prime \prime \prime}$, die Lange des Thorax beträgt $9 \frac{1}{3}$."

I think it more probable that the species Brandt describes belongs to $H$. brevirostris (Dana) than to $H$. palpator (Owen). I have never seen any specimen of palpator attain nearly such a large size as the specimen measured by Brandt. The other characters mentioned by Brandt agree perfectly with brevirostris. The locality at which Brandt's specimens were taken also favors this supposition, as brevirostris appears to be a more northern species than palpator, having been taken as far north as Vancouver's Island (Smith).

\section{Heptacarpus brevirostris (Dana).

$$
\text { Pl. III. f. } 5+51 \text {. }
$$

Hippolyte brevirostris DaNA, Proc. Acad. Nat. Sci. Phila., 1852, p. 24; Crust. U. S. Expl. Expd., Part I, 1852, p. 566, Pl. XXXVI, fig. 5. Stimpson, Proc. Cal. Acad. Ści., Vol. I, 1856, p. 89; Journ. Bost. Soc. Nat. Hist., Vol. VI, 1857, p.500; Proc. Acad. Nat. Sci. Phila., 1860, p. 33. BATE, in Lord's Nat. in Vancouver's Is., Vol. II, 1866, p. 279. Smith, Rep. Prog. Geol. Sur. Canada, 1878-9, B, p. 214. Kingsley, Bull. Essex Inst., Vol. X, 1878, p. 61. Lockington, Ibid., Vol. X, 1878, p. 160.

Hippolyte palpator BRAndt, Middendorff's Siberische Reise, Bd. II, Th. 1,185 l, p. 117.

Spirontocaris brevirostris WALKER, Trans. Liverpool Biol. Soc., Vol. XII, 189S, p. 276.

Allied to palpator, but larger and more robust. Carapace crested for a little more than its anterior third; rostrum short, not reaching the tip of the first joint of the peduncle of the antennules and armed above with five or six teeth, the last three or four of which are on the carapace, the posterior one being a little in advance of the middle; lower side of the rostrum devoid of teeth. The basal spine of the antennules reaches beyond the first joint of the peduncle; the spine above the articulation of the inner flagellum is very short; outer flagellum reaching beyond the antennal scale; inner flagellum about one-half longer than the outer. Antennal 
scale broad, short, about equal to the length of the telson; the peduncle extends abont two-thirds the distance to the tip of the acicle. Maxillipeds very large, similar to those of palpator; in adults the tip of the antepenultimate joint may reach the tip of the antennal scale. The first pair of chelipeds often reaches beyond the acicle. The relative lengths of the joints of the carpus of the second pair are about the same as in palpator; hand as long as the last three carpal joints. Posterior legs stouter than in palpator but otherwise very similar. Postero-lateral angle of the fourth abdominal segment broadly rounded but furnished with a minute spine-tooth; that of the fifth segment acute. Telson dorsally flattened, having four or five pairs of spinnles; tip rounded, wider than in palpator, and having several marginal setæ between the small median spine and the postero-lateral spines.

Length, $49 \mathrm{~mm}$; length of carapace, $16 \mathrm{~mm}$; of external maxillipeds, $32 \mathrm{~mm}$.

Sitka (Brandt); Vancouver's Island (Smith); Puget Sound (Dana); Humboldt County, Calif.! San Francisco Bay (Stimpson)!

Differs from palpator in its larger, stouter body, shorter rostrum, much shorter and broader antennal scale, and stouter posterior legs.

\section{Heptacarpus Taylori (St.) \\ Pl. II, f. $52+53$.}

Hippolyte Taylori Stimpsos, Journ. Bost. Soc. Nat. Hist., Vol. VI, 1857, p. 500. Kivgsley, Bull. Essex Inst., Vol. X, 1878, p. 61. LockingTON, Ibid., Vol. X, 1878, p. 160.

A short, plump species very closely allied to brevirostris, but the rostrum is shorter, reaching but very little beyond the anterior margin of the carapace and armed above with five or six teeth, the last three or four situated on the carapace; the teeth become more closely set and more strongly inclined forwards anteriorly, the end of the rostrum appearing curved downwards, although the lower margin is nearly horizontal; there is but one spine on the upper distal margin of the first joint of the antennules; the telson is narrower than in brevirostris, and the distance between the small median spine at the tip and the spines at the postero-lateral angles is not nearly so great, and there are only one or two marginal setæ on either side of the apex, instead of four or five as in the preceding species. None of the specimens of Taylori I have seen attain nearly the size reached by brevirostris. The rostrum is rarely so long as in that species, and when it is so it maintains its characteristic appearance. 
San Francisco Bay! Pescadero! Monterey! Magdalena Bay, Lower California (Lockington).

Although this species is very close to brevirostris, a comparison of several specimens of both species from different localities shows that they are distinct. Taylori is more southern in its range than brevirostris, but both species occur together in San Francisco Bay.

\section{Heptacarpus pictus ( $S t$.$) .$ Pl.III, f. $54+55$.}

Hippolyte picta Strmpson, Ánn. N. Y. Lyc. Nat. Hist., Vol. X, 1873, p. 125. KingsLey, Bull. Essex Inst., Vol. X, 1878, p. 62.

A small species, less robust than brevirostris or Taylori. Rostrum slender, straight, horizontal or slightly upturned and about two-thirds the length of the carapace; upper margin with six or seven quite evenly spaced teeth, the last two of which are on the carapace; lower margin with two to four teeth near the tip. The tip of the peduncle of the antennules reaches the middle of the antennal acicle but not the tip of the rostrum; the outer basal scale of the antennules reaches beyond the first joint of the peduncle but scarcely reaches the tip of the second joint; no spines on the distal margin of the first basal joint except the one at the external angle; no spine above the base of the slender flagellum; outer flagellum reaching a short distance beyond the tip of the antennal scale; inner flagellum about one-half longer than the outer. The antennæ may exceed the length of the body; acicle oblong, slightly tapering, and generally exceeding the tip of the rostrum. Maxillipeds shorter and more slender than in palpator, but reaching beyond the tip of the rostrum even in quite small specimens; last joint in adults about four times the length of the preceding one. Anterior chelipeds not reaching the tip of the antennal scale. The first and second joints of the carpus of the second pair are subequal; third joint about equal to the first two combined; fourth joint subequal to (or somewhat shorter than) the third, longer than the fifth, which exceeds the sixth; seventh joint considerably longer than the sixth; hand shorter than the last three joints of the carpus. Posterior legs moderately stout; the distal portion of the outer surface of the merus joints armed with a row of spines, which in the first pair often extends more than half way to the base; dactyls short, stout, about one-fourth the length of the propodi, and armed below with spines, the largest of which are near the tip. None of the abdominal segments are carinated above; postero-lateral angle of the fourth abdominal segment obtuse but having a small tooth; that of the fifth segment acute and produced into a spine. Telson rounded above and 
armed with four or five pairs of spinules; a small median spine at the tip, between which and the spines at the lateral angles there are one or two marginal setw.

Carapace beautifully marked with oblique crimson.bands; legs barred with crimson, the dactyls and tips of the propodi light colored.

Monterey (Stimpson); Santa Catalina Island! San Pedro! San Diego!

This beautiful little species is commonly found in tide pools. It is abundant at Monterey and San Pedro on rocky shores.

\section{Heptacarpus paludicola, sp. nov. Pl. III, f. $56+57$.}

Closely allied to picta. Rostrum slender, horizontal, about as long as the carapace, armed above with 6-S sharp, evenly spaced teeth, the last tooth on the anterior fourth of the carapace; lower margin armed with 2-4 teeth on the distal third or two-fifths. Antennular peduncle reaching two-thirds as far as the tip of the rostrum; basal spine extending beyond the tip of the first joint; upper distal margin of the first basal joint armed with a single spine at the outer angle. Antennal peduncie not reaching the middle of the acicle; acicle oblong, slightly tapering, closely resembling that of picta, and equalling the rostrum; flagellum as long as the body. Anterior chelipeds not reaching the tip of the acicle; hand narrow; palm fully as long as the carpus and about three times as long as wide. Second chelipeds about reaching the tip of the acicle; first joint of the carpus but little longer than the second, third and fourth subequal and each longer than the first, about equalling the fifth and sixth combined, fifth a little longer than the sixth and slightly shorter than the serenth; hand scarcely longer than the last two joints of the carpus. Posterior legs very slender; distal portion of the outer surface of the merus joints armed with a row of spines; dactyls short, about one-fourth the length of the propodi, narrower than in picta but similarly armed. Postero-lateral angles of the fourth abdominal segment subacute and furnished with a small tooth; that of the fifth segment acute. Sixth segment a little longer than in picta. Telson as in the preceding species. Color uniform green.

Humboldt Bay! Shelter Cove! Bodega Bay! June, 1894.

Large numbers of this species were caught in a trawl in the eel-grass in Humboldt Bay and Bodega Bay. The color is almost exactly that of the eel-grass in which 
they live. This species may be distinguished from picta by its larger size, different color, longer and more slender rostrum and the much more slender ambulatory legs. Collection University of California.

\section{Heptacarpus cristatus (St.).}

$$
\text { re.IIf. } 85+589 \text {. }
$$

Hippolyte cristata Stimpson, Proc. Acad. Nat. Sci. Phila., 1860, p. 33. Kingsley, Bull. Essex Inst., Vol. X, 1878, p. 62.

Spirontocaris cristata WALKER, Trans. Liverpool Biol. Soc., Vol. XII, 1898, p. 277.

Less robust than Taylori. Rostrum rather narrow, about two-thirds the length of the carapace, arched over the eyes where the teeth are most thickly set, and armed above with 5-8 teeth, the posterior two or three being on the carapace, while the most anterior one is situated some distance behind the tip; lower margin with two or three teeth near the tip. The basal spine of the antenuules reaches a little beyond the tip of the first joint. Antennal scale considerably longer than the rostrum and narrower than in palpator or Taylori; flagellum longer than the body. Maxillipeds reaching to or beyond the tip of the acicle; hand of the anterior chelipeds long and narrow. Second pair of chelipeds reaching the tip of the acicle; first joint of the carpus slightly longer than the second; third about as long as the first two; fourth, fifth and sixth decreasing snccessively in length; seventh longer than the fourth; hand nearly as long as the last three joints of the carpus. Posterior legs more slender than in palpator, the merus joints armed with spines on the distal portion of the outer surface; dactyls long, slender, evenly tapering, about half the length of the propodi. Abdomen moderate, none of the segments carinated above; postero-lateral angles of the fourth segment rounded but generally bearing a minute spine; those of the fifth segment acute and having a larger spine. Telson rounded above and having three pairs of dorsal spinules.

San Francisco Bay (Stimpson); Monterey! San Diego!

Easily distinguished from the other species described here by its long, slender dactyls.

\section{Heptacarpus carinatus, sp. nov.} Plitt. 7. 60 .

Carapace small in comparison to the abdomen; antennal spine well developed, larger than the spine at the antero-inferior angle. Rostrum rather narrow, evenly tapering, about equalling the carapace in length, 
the upper margin armed with 4-6 small teeth, the posterior one on the carapace, the anterior one a little behind the middle of the rostrum; lower margin armed with 4-6 teeth, the anterior tooth commonly near the tip. Ocular peduncles with an ocellus on the posterior side. The spine on the outer side of the base of the antennules reaches abont to the tip of the first joint; antennal scale narrow, about equalling the length of the rostrum, the sides parallel, the inner, membranous portion projecting much beyond the outer distal spine; flagellum about as long as the body; the peduncle reaches about as far forward as the penultimate joint of the peduncle of the anteunules. The external maxillipeds scarcely reach as far forward as the middle of the rostrum; last joint flattened, somewhat twisted, the tip armed with dark colored spines. The anterior chelipeds do not reach as far forward as the maxillipeds; hand thick at the base. Second pair of chelipeds reaching beyond the tip of the antemnal peduncle; first and third joints of the carpus subequal and longer than the second; fourth and fifth joints subequal and shorter than the third; sixth joint the shortest of all; seventh about as long as the two preceding ones combined; hand narrow, the palm a little longer than the last joint of the carpus. Posterior legs rather stout, the extero-distal angles of the merus joints armed with 1-3 spines, the last pair seldom having more than one. The third segment of the abdomen is posteriorly produced and crested. Telson with four pairs of spines on the dorsal surface.

Dredged in large numbers in shallow water in Monterey Bay, November, 1895.

The color varies with the surroundings. Specimens among the bright green sea-weeds are of a uniform bright green color, while other specimens living only a few yards away among the red sea-weeds imitate almost exactly the color of the algæ that surround them.

Collection University of California. USiv $89579-7 \%$

\section{Heptacarpus tenuissimus, sp. nov.}

- A very slender species. Anterior half of the carapace crested. Suborbital and antennal spines well developed. Rostrum longer than the carapace, horizontal and very slender, scarcely higher than wide, gently arching over the eyes, and armed above with four spines, the posterior spine on the carapace, the anterior one near the middle of the rostrum, the distal half of the upper margin being smooth; lower side of the rostrum with tive teeth. Basal spine of the antennules scarcely reaching the tip of the first joint. Acicle long and narrow, about equalling the rostrum, the 
sides parallel; peduncle not reaching the middle of the acicle. Maxillipeds rather short. Anterior chelipeds scarcely reaching the tip of the antennal peduncle. The three posterior pairs of legs are slender and have short dactyls. Abdomen slender, the third joint rounded above but produced backwards in the middle. Telson narrow and armed above with seven pairs of minute spinules.

Length, $25 \mathrm{~mm}$.

One specimen collected at Monterey by Dr. H. P. Johnson. USNMT 86808

Easily distinguished from all the other species of Heptacarpus by its very slender, elongated body and very narrow rostrum. Collection University of California.

\section{Heptacarpus Herdmani (Walker).}

Spirontocaris Herdmani WALKER, Trans. Liverpool Biol. Soc., Vol. XII, 1898, p. 277, Pl. XVI, fig. 2; Ann. Mag. Nat. Hist. (7), Vol. II, 1898, p. 276.

Carapace with a subocular spine and a small tooth at the antero-inferior angle. Rostrum horizontal, a little shorter than the carapace, the dorsal carina continued back upon the carapace nearly to the middle; "upper margin with five teeth, of which two are on the thorax, the second, third and fourth close together, the distance from the fifth to the point equal to the length from the second to the fourth. Lower margin with one tooth near the point." Maxillipeds reaching considerably beyond the tip of the acicle. First pair of legs reaching beyond the tip of the acicle, "the propodus as wide and more than twice as long as the carpus." "Abdominal segments having the lower margin rounded in the first four, acute in the fifth."

"One female with ova. Length, $30 \mathrm{~mm} . "$

\section{Heptacarpus ? stylus (St.).}

Hippolyte stylus Srimpson, Proc. Acad. Nat. Sci. Phila., 1864, p. 154. Kingslex, Bull. Essex Inst., Vol. X, 1878, p. 62.

Body slender. Carapace smooth, not crested, except for a short distance in front. Rostrum slender, styliform, perfectly straight and equal to the carapace in length; the upper side is armed with four or five teeth near the base, while the anterior two-thirds is devoid of teeth; lower side with five or six teeth. An antennal spine present but no supraorbital or pterygostomiau spine. Antennal scale oblong, scarcely shorter than the rostrum 
and obliquely truncate at the end. Maxillipeds very small, reaching only to the end of the antennal peduncle, or to the basal third of the rostrum; there is an epignath but no exognath. None of the pereopods have an epipod. Telson with four pairs of spinules on the dorsal surface.

Length, $1 \frac{1}{2}$ inch.

\section{Straits of Fuca (Stimpson).}

\section{Heptacarpus? Suckleyi (St.).}

Hippolyte Suckleyi Stimpson, Proc. Acad. Nat. Sci. Phila., 1864, p. 154.

Kingslex, Bull. Essex Inst., Vol. X, 1878, p. 62.

Carapace with the anterior half crested and sloping forwards. An anteunal and pterygostomian spine present but no supraorbital spine. Rostrum scarcely as long as the carapace, rather broad and curved, with a slender, acute tip; upper margin six-toothed, beginning at the anterior third of the rostrum; lower margin four-toothed. Maxillipeds reaching nearly to the tip of the acicle and devoid of an exognath or epignath. Pereopods long, the last pair nearly reaching the tip of the rostrum; first pair only provided with an epipod; dactyls of the last three pairs elongated, with only one terminal claw. Abdominal segments with smooth margins, the superior margin of the third segment obtuse.

Length, $1 \frac{1}{2}$ inch.

\section{Puget Sound (Stimpson).}

\section{Heptacarpus? gracilis (St.).}

Hippolyte gracilis Strmpson, Proc. Acad. Nat. Sci. Phila., 1864, p. 155. Kingsley, Bull. Essex Inst., Vol. X, 1878, p. 62.

A slender species. Carapace crested on the anterior third. Rostrum very slender, scarcely higher than wide and a little longer than the carapace; the upper side is armed with four teeth over the eye, in front of which it is smooth to the tip; lower side armed with four minute distant teeth. An antennal and a pterygostomian spine present. The thick flageilum of the antennules reaches the tip of the rostrum. Acicle a little longer than the rostrum. The maxillipeds reach the middle of the rostrum and have no exognath. Pereopods very slender and devoid of an epipod. Abdomen very long and strongly geniculated, the third segment compressed and prominent, penultimate joint much elongated.

Length, $1 \frac{1}{4}$ inch.

Puget Sound (Stimpson). Found in deep. water. 


\section{Genus Spirontocaris Bate.}

Carapace anteriorly carinated and produced into a deep, laterally compressed rostrum which is serrated ou both margins. There are two or more supraorbital spines, an antennal spine, and a spine at the anteroinferior angle of the carapace. First and second antennæ much as in Hippolyte. Mandibles with a broad molar process, a slender apical process, and a small, two-jointed palp. Third maxillipeds furnished with a small exognath and having the tip of the last joint armed with spinules. First pair of pereopods short, robust; second pair slender, the carpus sevenjointed. Posterior pereopods subequal, similar, and furnished with biunguiculate dactyls which are spinulous below.

T'ype.-S. spinus (SowERBY).

\section{Spirontocaris prionata (St.).}

Hippolyte prionata Strmpson, Proc. Acad. Nat. Sci. Phila., 1864, p: 153. KIngsley, Bull. Essex Inst., Vol. XIV, 1883, p. 127, P1. II, fig. 9. Sharp, Proc. Acad. Nat. Sci. Phila., 1893, p. 117.

Spirontocaris prionata WALKER, Trans. Liverpool Biol. Soc., Vol. XII, 1898, p. 277.

Carapace large, the anterior margin furnished with two spines, of which the upper one is the larger. There are two or three supraorbital spines in a longitudinal series; the upper side is crested nearly to the posterior margin and cut into three large teeth whose transverse anterior margins are armed on either side with several small spines. Rostrum very broad, widest a little behind the tip, the upper margin thickly set with small spines, while the lower margin is furnished with four cr five larger spines. Antennules short, the external basal spine large, reaching about to the tip of the peduncle; the first joint of the peduncle is longer than the next two and has a spine at the antero-external angle; second joint with a large spine on the outer side; third joint with a slender spine above the articulation of the larger flagellum and a similar spine near the articulation of the slender one; thick flagellum longer than the slender one, with a slender tip about one-third the length of the proximal portion. Antennæ somewhat shorter than the body; acicle subtriangular, about reaching the tip of the rostrum; peduncle not reaching the middle of the acicle. Mandibles stout, cutting edge long, slender, distally four-toothed, and slightly longer than the palp; palp two-jointed, the last joint narrow and about twice as long as the first. Maxillipeds very stout and exceeding the tip of the rostrum, the last two joints bent downwards; the antepenultimate joint is somewhat widened at the tip where it bears, on the upper side, two small prominences, each of which bears a spine and numerous setro last joint over twice the length of the preceding one, the tip armed with a circle of dark-colored spines; exopod small, scarcely reaching the tip of 
the antepenultimate joint. First pair of chelipeds not reaching the middle of the antennal scale; hand oblong, thick, the tips of the fingers hooked. Posterior legs stout, setose; dactyls about half the length of the propodi. Abdomen short, contracted behind the fifth segment; all the segments are rounded above but the third is produced backwards in the middle into a rounded, triangular process; the postero-lateral angles of the fourth and fifth segments are produced into an acute tooth. Telson flat above where it is armed with four pairs of spinules; tip armed with two pairs of spines (the inner pair being the longer) and a short, median spine or tooth.

\section{Puget Sound (Stimpson); Marmot Isles, Alaska (Sharp); Monterey!}

\section{Spirontocaris bispinosus, sp. nov.}

Carapace with two supraorbital spines, a triangular, tooth on the margin below"the orbit, and a short distance below this a spine behind the base of the antenna; antero-inferior angle of the carapace with an obsolescent spinule. Rostrum a little longer than the carapace, strongly upturned, with the basal half high and laminate, but abruptly contracted near the middle into a slender, styliform process; the rostrum is continued backward over the anterior two-thirds of the carapace as a carina; the npper margin is armed with 10-12 teeth which decrease in size and become more closely set anteriorly, there being several small teeth crowded together where the rostrum is abruptly narrowed, the two posterior teeth on the carapace; distal half of the upper margin devoid of teeth; lower margin armed with three or four low teeth on the basal half and a single tooth on the slender process. Eyes pyriform with very large cornex. Basal spine of the antennules reaching the middle of the second joint of the peduncle. Antennæ much longer than the body; acicle not nearly reaching the tip of the rostrum; peduncle reaching middle of acicle. Mandibles avith a slender apical process; palp two-jointed, subequal to the apical process, the first joint broad; second joint narrow, about twice as long as the first. Maxillipeds not quite reaching the tip of the acicle; exognath slender, not nearly reaching the tip of the antepenultimate joint. First chelipeds rather slender, nearly reaching the tip of the antennal peduncle; carpus not distally excavated and longer than the palm of the narrow elongated hand. Second chelipeds exceeding the acicle, carpus seven-jointed, third joint longer than the first two. Posterior legs long and slender, merus armed externally with spines, dactyls very slender. All the abdominal segments are rounded above. Telson rounded above and armed with three pairs of dorsal spines.

Puget Sound, June, 1898, five specimens. Collection University of California. 


\section{Spirontocaris lamellicornis (Dana).}

Hippolyte lamellicornis Dana, Proc. Acad. Nat. Sci. Phila., 1852, p. 24; Crust. U. S. Expl. Expd., Part 1, 1852, p. 567, Pl. XXXVI, fig. 6. Stimpson, Journ. Bost. Soc. Nat. Hist., Vol. VI, 1857, p. 498. KingsLEY, Bull. Essex Inst., Vol. X, 1878, p. 62.

Spirontocaris lamellicornis WALKER, Trans, Liverpool Biol. Soc., Vol. XII, 1898, p. 277.

"Beak long, broad, lamellate, produced nearly to posterior margin of thorax, bifid at apex, undulate above, four spines upon cephalothorax and about six upon proper beak, teeth or spines unequal, all nearly equally spaced; outline of beak below triangulately salient, two-dentate. Inner antennæ little longer than the beak. Apterior feet very slender, but little stouter than the next pair. Second pair hardly shorter than the third, carpus elongate, seven-jointed, third joint quite long. Tarsi of following pairs nearly unarmed, a few very minute spinules towards the base. Outer maxillipeds spinulous at apex, last joint pubescent above.

"Length of body one and one-half to two inches. The four dorsal spines are rather larger than those of the beak proper; and the first and last of the latter (not counting the bifid tip), are much smaller than the others; the outline of the whole is separately arcuate along the back and along the beak, with a concave outline between the two parts. The naked tarsus is peculiar. The base of the inner antennæ is hardly as long as half the beak, and the flagella scarcely reach beyond the tip of the beak. The second and third joints of the abdomen have the lateral margin triangulate or obtusely pointed, and in the next two this margin is acute. The third joint of the carpus of the second pair of feet is twice as long as the first and second joints together. The six posterior legs are nearly naked.

\section{"Dungeness, in the Straits of De Fuca, Northwest America."}

\section{Species not seen.}

\section{Family PANDALID $Æ$.}

Rostrum long, slender and spiny. Eyes free. Mandibles with a twoor three-jointed palp. First pair of pereopods simple; second pair chelate, with the carpus annulated. 


\section{Genus Pandalus Leach.}

Carapace smooth. Rostrum armed above and below with teeth and continued backward upon the carapace as a carina. Second pair of pereopods with the carpi unequal and multiarticulate.

Type. $\rightarrow P$. annulicornis LEACH.

\section{Pandalus Danæ St. PI.II. $7.61+62$}

Pandalus Dana Stimpson, Proc. Bost. Soc. Nat. Hist., Vol. VI, 1857, p. 87; Journ. Bost. Soc. Nat. Hist., Vol. VI, p. 502, Pl. XXI, figs. 6 and 7, 1557. Cooper, Rep. Expl. and Sur. to Pac. Ocean, Vol. XII, Book 2, 1860, p. 389. Kingsley, Bull. Essex Inst., Vol. X, 1878, p. 64. Sмiтh, Rep. Prog. Geol. Sur. Canada, 1878-9, B, p. 214. Rathbun, R., The Fisheries of the U. S., Sec. ], 1884, p. 821. Sharp, Proc. Acad. Nat. Sci. Phila., 1S93, p. 115.

Rostrum slender, about as long as the carapace and quite strongly upturned; upper margin armed with 10-12 sharp teeth, the posterior five of which are on the carapace, the last one a little behind the middle, the anterior half of the upper margin of the rostrum smooth; apex. trifid; lower margin armed with six or seven teeth which decrease in size anteriorly, the posterior tooth large and curved strongly forwards. Subocular spine well developed; antennal spine small. The appendage on the outer side of the basal joint of the antennules is small, lamellate, rounded at the tip and not reaching as far as the middle of the joint; inner flagellum longer than the outer one. Antennal scale narrow, tapering, not nearly so long as the rostrum; two spines on the onter side of the second joint of the peduncle; flagellum longer than the body. The maxillipeds do not reach the tip of the rostrum and may fall short of or exceed the tip of the acicle. First pair of legs shorter than the maxillipeds, the merus produced forwards at the infero-distal angle into a spine. Second pair elongated, very unequal, the longer member with a sharp crest on the inferoproximal portion of the ischium; the merus and distal end of the ischium are closely annulated; carpus very long, slender, divided into very numerous anuulations and channeled along one side; hand oblong, narrow, the fingers scarcely as long as the palm; the shorter cheliped is variable in length, exceeding or not equalling the tip of the rostrum; the ischium is not distally annulated and the merus is obscurely annulated, but the annulations of the carpus are distinct; hand similar to that of the longer cheliped. The three following pairs of legs are spinous and rather stout, decreasing in length posteriorly, the dactyls short and spinulous below. The postero-lateral angle of the fifth abdominal segment is rounded, but furnished with a minute tooth; that of the fifth segment 
subacute and furnished with a similar tooth. Telson a littie shorter than the uropods, furnished with a shallow superior groove, at the proximal end of which is a small tuft of hairs, and armed above with seven or eight pairs of spinules.

Length, $124 \mathrm{~mm}$.; length of carapace including rostrum, $58 \mathrm{~mm}$.; rostrum, $30.5 \mathrm{~mm}$; left cheliped, $67 \mathrm{~mm}$; right cheliped, $42 \mathrm{~mm}$; third pereopods, $65 \mathrm{~mm}$.

\section{Alaska (Sharp); Vancouver's Is. (Smith); Puget Sound (Cooper); San Francisco Bay (Stimpson)!}

\section{Pandalus pubescentulus Dana.}

Pandalus pubescentulus Dana, Proc. Acad. Nat. Sci. Phila., 1852, p. 24; Crust. U. S. Expl. Expd., Part 1, 1852, p. 568, Pl. XXXVI, fig. 8. Stimpson, Journ. Bost. Soc. Nat. Hist., Vol. VI, 1857, p. 501. KingsLEY, Bull. Essex Inst., Vol. X, 1878, p. 63. Sмгтн, Rep. Prog. Geol. Sur. Canada, 1878-9, B, p. 214.

"Carapax densely very short pubescent, margin below the eye with two spines. Beak longer than the basal scale of outer antennæ; ensiform, somewhat recurved, but apex not raised above level of back, 16-18 toothed above, teeth small and continued nearly to middle of back, towards apex unarmed, apex bifid, below seven-toothed. Feet nearly naked, third, fourth and fifth pair decreasing regularly in length, anterior pair but little longer than the first three joints of second pair.

"Length of body, 5 inches; of carapax, $2 \frac{1}{4}$ inches; of beak to the posterior tooth on the back, $1 \frac{5}{8}$ inches; of beak to the orbital sinus, its proper base, $1 \frac{1}{4}$ inches.

"Straits of De Fuca, at Dungeness, Oregon."

This species has been reported from Vancouver's Is. by Smith.

\section{Pandalus Gurneyi St.}

Pandalus Gurneyi Strmpson, Ann. N. Y. Lyc. Nat. Hist., Vol. X, 1873, p. 128. Kingstey, Bull. Essex Inst., Vol. X, 1878, p. 63.

"A large species, of the same size as $P$. borealis, etc. Surface of the carapax marked with shallow pits in clusters; not pubescent. Rostrum more than one-half longer than the carapax and unarmed above, except near the base, where the crest has eight or nine teeth, four of which are on the carapax; these teeth are small and rather distant. Below the rostrum is armed with nine teeth, the two teeth next the base being rather 
close together, large, and hook-shaped, but not broad. The feet of the third pair are rather short, not reaching the extremity of the rostrum; they terminate in well-formed, subcheliform hands.

"Found at Monterey, Calif., by A. S. Taylor, Esq."

\section{Pandalus franciscorum Kingsley.}

Pandalus franciscorum Krygsley, Proc. Acad. Nat. Sci. Phila., 1878, p. 94; Bull. Essex Inst., Vol. X, 1878, p. 63.

"Carapax with a miunte pubescence; antennal and branchiostegal spines acute; rostrum a fifth longer than the carapax, extending a fourth its length beyond the antenual scales, considerably recurved, ten or eleven teeth above, of which five are on the carapax and the remainder on the basal portion of the rostrum; distal half of the rostrum above smooth, the apex being minutely bitid or trifid; below with seven to nine teeth, the posterior being the largest. Third joint of the antennular peduncle a third longer than the preceding; flagella about as long as the carapax. Basal joint of the antennæe with a spine on the outside and another below; antennal scale long and proportionately narrower than in $P$. borealis Kröyer; flagellnm longer than the body. External maxillipeds falling short of the extremity of the antennal scale. Second pair of feet unequal, the shorter extending further forwards than the external maxillipeds. Posterior pairs stout, armed with spines below. Fifth and sixth abdominal segments with a spine at the infero-posterior angle. Telson narrow, a shallow furrow on its upper surface, apex obtusely triangular.

"Length, $110 \mathrm{~mm}$; carapax, $52 \mathrm{~mm}$.

"San Francisco, Calif., W. G. W. Harford."

\section{Family ATYIDÆ.}

Mandibles stout and divided, but not deeply so, and devoid of a palp. First two pairs of pereopods chelate, the tips of the fingers furnished with hairs. Rostrum variable. Fresh water forms.

\section{Syncaris, gen. nov.}

Carapace not carinated in front and armed with supraorbital and antennal spines. Rostrum long and slender, armed with teeth on one or both sides, and rounded above at the base. Antenuules biflagellate, the onter flagellum with a thickened basal portion. External maxillipeds furnished with an exognath. Two or more pairs of pereopods furnished with exopods. First pair of chelipeds short and rather stout; carpus short and 
distally excavated to receive the propodus. Second pair of chelipeds longer and more slender than the first, the carpus long and not distally excavated. The three following pairs of pereopods are longer than the. chelipeds; dactyls very short and spinulous below. All the abdominal segments rounded above. Tip of the telson truncated or broadly rounded.

Type.-S. pacifica (HoLmes).

This genus is intermediate between Atyephyra and Xiphocaris as defined by Ortmann. ${ }^{1}$ The latter genus, according to Ortmann, contains besides the type, $X$. elongata, the Ephyra? compressa of De Haan which Von Martens had placed in Atyephyra and for which Miers. had constituted provisionally the genus Paratya. Mr. Ortmann recognizes but one species of Atyephyra, viz., Desmarestii (the Caridina Desmarestii of Joly), which Brito Capello described as Atyephyra rosiana, making the new genus Atyephyra to receive it. Desmarestii being generically distinct from Caridina in the strict. sense becomes, therefore, the type of Atyephyra. Our two species differ from $A$. Desmarestii in not having the carpus of the second pair of pereopods distally excavated, in having the anterior part of the carapace rounded above instead of armed with a dentate carina and in having a prominent suborbital spine. S. Trewi approaches Atyephyra, however, in having exopods only on the first two pairs of pereopods instead of the first four as in pacifica. From Xiphocaris elongata both of our species differ in having supraorbital spines, in the less number of exopods, and in having the carpus of the first pair of chelipeds excavated. They approach more nearly $X$. compressa (De Haan), for in that species supraorbital spines are present, though there are exopods on all the pereopods, and the carpus of the anterior chelipeds is not hollowed out.

\footnotetext{
1 Proc. Acad, Nat. Sci. Pbila., 1894, p. 399.
} 
It was owing to the affinities of my pacifica with $X$. compressa (De Haan) that I was led to put the former species in the genus Miersia, the Ephyra? compressa (De Haain) having been placed in Miersia in Kingsley's revision of the genera of the Atyidæ. Mr. Kingsley, however, was wrong in referring compressa to Miersia, for, as Bate has pointed out, the type of that genus, $M$. pelagica, is marine and belongs properly in a different family.

\section{Syncaris pacifica (Holmes).}

Miersia pacifica Holmes, Proc. Cal. Acad. Sci. (2), Vol. IV, 1595, p. 577, PI. XXI, figs. 27 and 28.

Rostrum slender and about as long as the carapace; upper margin armed with one or two spines, the lower with 5-9 spines. A pair of supraorbital spines. Antennular flagella subequal, the outer one with a thickened basal portion. Antennal scale reaching about to the tip of the rostrum. All the pereopods except the last pair furnished with exopods. The first pair of legs is short, the carpus short and distally widened, the end excavated to receive the basal prominence of the palm. Second pair of legs longer than the first; carpus longer than the hand. The three following pairs are subequal; dactyls short. Telson tapering to a truncated or broadly rounded tip.

Length, $5 \mathrm{~cm}$.

Sonoma County, Calif., (L. E. Ricksecker coll.) Types in the Museum of the California Academy of Sciences.

\section{Syncaris Trewi, sp. nov.
Pl.IV, f.63.}

Carapace with supraocular and subocular spines; a tooth at the antero-inferior angle. Rostrum slender, slightly upturned, and about one-half the length of the carapace; the upper side is rounded and devoid of teeth, the lower margin armed with 3-5 teeth on its distal half. The basal spine of the antennules reaches slightly beyond the tip of the first joint; flagella subequal and about as long as the carapace exclusive of the rostrum; the basal third of the outer flagellum is markedly thicker than the distal portion. Antenum nearly as long as the body; acicle oblong, about equalling the rostrum, sides nearly parallel, tip broadly rounded and projecting considerably beyond the spine at the end of the onter 
margin. Maxillipeds not reaching the tip of the rostrum, the exognath not reaching the tip of the penultimate joint. Anterior chelipeds short; carpus short and excavated to receive the propodus. Second pair of chelipeds much longer than the first, carpus much longer than the hand and not distally excavated. The succeeding pereopods are longer than the chelipeds; merus and carpus with a few spines on the outer side; dactyls of the first two pairs about one-fourth the length of the propodi and armed below with numerous spines; dactyls of the last pair longer than those of the preceding pairs and of a different shape, the lower margin finely pectinated nearly to the terminal claw behind which are two spines. Telson rounded above and tapering to a broadly rounded or truncated extremity; upper surface armed with two pairs of short spines. Uropods longer than the telson.

Length 1.5 in.

Described from four specimens collected in a small stream near San Gabriel, Los Angeles County, Calif., by Mr. N. C. Trew. All the exopods in some of the specimens were broken off, but in others they were present on the first two pairs of pereopods. I have found no trace of exopods on any of the posterior pairs; they may have been present and become broken off but I do not think this is probable. Collection University of California. using 86807 4:

\section{Genus Caridina Milne-Edwards.}

Carapace with a well developed rostrum. Pereopods devoid of exopods. Carpus of the first exopods distally excavated; that of the second pair not excavated.

Type.-C. typus MiLne-EDwaRds.

\section{Caridina pasadenæ Kingsley.}

Caridina pasadence Kingsley, Bull. Essex Inst., Vol. XXVII, 1897, p. 98, P1. III, figs. 1-7.

Carapace not carinated anteriorly and furnished with a suborbital and an antenual spine. Rostrum three-fourths the length of the carapace, smooth above, bifid at the apex, and occasionally armed with a single tooth on the lower margin. Basal scale of the antennules reaching slightly beyond the tip of the first joint; inner margin of the first joint 
armed with a small spine. Antenne about two-thirds the length of the body; acicle narrow, reaching slightly beyond the tip of the antennular peduncle. Exognath of the external maxillipeds slender, not reaching the tip of the merus. First chelipeds short, rather stout; second pair twice the length of the first, the carpus much longer than the hand. Posterior pereopods elongated, dactyls curved, spinulous below.

Length, 32-39 $\mathrm{mm}$.

From streams near Pasadena, Calif., where it is said to be common. This species bears some resemblance to the form from near the same locality which is here described as Syncaris Trewi. It differs from the latter in having fewer teeth on the lower side of the rostrum, and, according to Kingsley's fig. 1, in the absence of a supraorbital spine. Kingsley's fig. 6, which represents a mandible with a two-jointed palp, probably refers to the mandible of Naushonia and not, as is stated in the explanation of the figures, to that of Caridina.

\section{Family PALAMONID止.}

Body compressed. Carapace dorsally rounded and furnished with a long, laterally compressed rostrum which is generally armed with teeth. Ocular peduncles well developed. Antennules with the first joint hollowed on the upper surface and furnished with a well developed basal spine; flagella two, one of which is frequently branched. Antennæ long, with a long acicle, the onter margin of which terminates in a tooth or spine. Mandibles with a molar tubercle and a cutting edge, with or without a palp. Third maxillipeds pediform. First two pairs of pereopods chelate; the carpus of the second pair not annulated.

\section{Genus Palæmon Fabr.}

Rostrum long, deep, dentate above and below. Frontal margin of the carapace armed with two teeth, the one above the other. No hepatic spine. Ocular peduncles pyriform and provided with an ocellus. Antennules with two long flagella, the outer one branched. Mandibles with a threejointed palp. External maxillipeds slender, with a short exognath. First pair of chelipeds slender; second pair larger than the first; the carpus elongated. 


\section{Palæmon Ritteri Holmes.}

Palamon Ritteri Holmes, Proc. Cal. Acad. Sci. (2), Vol. IV, 1895, p. 579, Pl. XXI, figs. 29-35.

Carapace crested on the anterior third or half. A spine beneath the angular suborbital projection of the anterior margin of the carapace and another spine behind the base of the antenna and above the rounded inferior angle. No hepatic spine. Rostrum a little longer than the carapace, tapering gradually from the widest portion to the acute tip; upper margin armed with seven or eight teeth, the posterior one of which is situated on the gastric region; lower margin with three teeth. Antennal scale oblong, shorter than the rostrum. First pair of chelipeds slender, not reaching beyond the tip of the rostrum; carpus devoid of a spine; hand slender. Second pair solnewhat larger than the first; carpus not half as long as the preceding joint; hand linear and slightly bent.

Length, $4.5 \mathrm{~cm}$.

$$
\text { San Diego, Calif. (Dr. Ritter). }
$$

\section{Genus Anchista Dana.}

Rostrum long and slender. Eyes prominent. Antennules with one flagellum partly divided. Mandibles devoid of a palp. External maxillipeds slender. Second pair of pereopods long, slender and equal. Dactyls slender, long, and nearly straight.

Type. $-A$. gracilis Dara.

\section{Anchista tenuipes, sp. nov.}

Rostrum about as long as the carapace, rather deep near the middle, armed above with six or seven teeth, the last one or two on the carapace; lower side armed with three or four teeth; the last dorsal spine is near the anterior third of the carapace. A supraorbital, an antennal and a hepatic spine present; antero-lateral angle of the carapace rounded and devoid of spines. Ocular pednncles large and furnished with an ocellus between the cornea and the proximal part of the stalk. Antennular peduncle shorter than the antennal scale; first joint with a small spine at the antero-external angle, the basal spine small, not reaching the middle of the joint; second and third joints of subequal length; flagella longer than the peduncle, the lower one very slender. Antennæx about as long as the body; a spine on the outer angle of the second basal joint; acicle oblong, equalling or exceeding the rostrum. Maxillipeds slender, not neariy reaching the tip of the acicle; exognath reaching considerably beyond the antepenultimate joint. Anterior pereopods very slender, and reaching scarcely beyond the 
carpus of the second pair; carpus slightly longer than the merus; hand very narrow, shorter than the carpus; fingers straight, subequal to the palm. Second pair of pereopods slender and greatly elongated, the carpus reaching beyond the rostrum; ischium, merus and carpus of subequal length, the latter furnished with two teeth at the distal end; hand long, very narrow, subcylindrical, exceeding the length of the carpus and merus combined; fingers slender, straight, about two-thirds as long as the palm, the tips hooked and crossed when the fingers are closed. The ambulatory legs are very slender, nearly naked, and subequal. The postero-lateral angle of the fifth abdominal segment is rounded, that of the sixth acute. Telson with two pairs of dorsal spinules.

Length of body, $18 \mathrm{~mm}$; of second chelipeds, $16 \mathrm{~mm}$.; of hand, $7 \mathrm{~mm}$.; of carpus, $3 \mathrm{~mm}$.

Santa Catalina Island, August, 1893; three specimens.

Closely allied to $A$. ensifrons Dana from north of Borneo, but is distinct. Collection University of California.

\section{Subtribe PENÆIDEA.}

Gills dendrobranchiate. Third pair of pereopods and frequently the first and second pairs chelate; the first pair never very large and stout, usually smaller than the others. Fourth and fifth pairs of pereopods always devoid of chelæ.

\section{Family PENÆIDÆ.}

Carapace generally compressed and produced backwards at the sides. Rostrum compressed and usually continued back upon the carapace as a carina. Eye-stalks generally two-jointed. Antennules biflagellate; first basal joint with an external spine and an unjointed appendage on the inner side; upper surface excavated. Antennæ long, with a large acicle. Mandibular palp never more than two-jointed. Third maxillipeds long and pediform. First three pairs of pereopods chelate and similar. Abdomen long and compressed, more or less carinated above; the sides of the first segment produced so as to overlap the sides of the carapace in front and those of the second segment behind.

\section{Genus Penæus Fabr.}

Body strongly compressed. Rostrum prominent, serrated. Eye-stalks two- or three-jointed. Flagella of the antennules not longer than the carapace. Mandibular palp two-jointed. First three pairs of pereopods 
chelate and furnished with small exopods and increasing in length posteriorly. No podobranchiæ. All the abdominal appendages bear two foliaceous branches except the last pair which, in the male, carries attached to the base a large, membranous appendage, which in the female is reduced to a rudiment.

\section{Penæus californiensis, sp. nov.}

Penceus canaliculatus Holmes (not Olivier), Proc. Cal. Acad. Sci. (2), Vol. IV, 1895, p. 581 .

$$
\text { Pl. IF, } 6.64-69
$$

Rostrum slender. acumilate, slightly arched, the upper margin ciliated and armed with nine or ten teeth, the last tooth on the gastric region and separated by an unusually wide interval from the preceding tooth; lower margin with two small teeth; the rostrum is continued backward upon the carapace as a carina nearly to the posterior end, its dorsal surface sulcate posterior to the last tooth; on either side a prominent groove which terminates abruptly a short distance in front of the posterior margin of the carapace; the outer margins of these grooves spread outward near the last rostral tooth and are continued anteriorly npon the lateral ridges of the rostrum. Above the base of the antennæ there is a strong marginal spine which is continued backwards into a carina; above this is a wide, oblique groove, at the posterior end of which is a small hepatic spine; a narrow groove, running obliquely downwards, joins the wide groove immediately above this spipe. Antero-lateral angle of the carapace rounded, with a sinus above. Antennular peduncle equalling or a little exceeding the rostrum, the inner appendage of the first joint long, narrow and ciliated; flagella much shorter than the peduncle. Antennal scale reaching about as far forward as the tip of the rostrum; the flagellum may exceed the length of the body. Chelipeds becoming more slender posteriorly and increasing in length, owing mainly to the increase in the length of the carpus; the second joint in the first two pairs has a spine at the distal end of the lower margin, and there is a second spine in the first pair on the lower side of the ischium; the chelro become longer and narrower posteriorly; the first is nearly as long as the carpus, while the third is scarcely half as long as that joint; two posterior pairs of pereopods subequal. The three anterior abdominal segments are not carinated above; the fourth is carinated at least on the posterior portion; fifth segment carinated, but not ending posteriorly in a tooth; the carina on the sixth segment is acute, with a groove on either side, and terminates in a tooth at the posterior end. Telson acute, about as long as the preceding segment, devoid of lateral spines, and furnished with a conspicuous dorsai groove, which extends from the anterior end to the tip. The uropods extend far beyond the telson: 
Length from tip of rostrum to tip of telson, $182 \mathrm{~mm}$; rostrum, $24 \mathrm{~mm}$; carapace including rostrum, $41 \mathrm{~mm}$; acicle, $27 \mathrm{~mm}$.; exterual maxillipeds, $45 \mathrm{~mm}$.; first chelipeds, $35 \mathrm{~mm}$.; carpus and hand of same, each $8 \mathrm{~mm}$.; carpus of second chelipeds, $14 \mathrm{~mm}$.; hand of same, $9 \mathrm{~mm}$.; carpus of third chelipeds, $23 \mathrm{~mm}$; hand of same, $10.5 \mathrm{~mm}$.; sixth abdominal segment, 25 mm.; height of same, $19 \mathrm{~mm}$.

Specimens examined, one male from near Anaheim, Calif., and two specimens, male and female, from San Francisco Bay.

Closely allied to $P$. braziliensis but having shorter and stouter legs. This species is also closely allied to canaliculatus, but, so far as I can obtain information concerning the latter species, our California forms differ from it in having a tooth at the posterior end of the sixth abdominal segment, in having the longitudinal ridges on the carapace spreading somewhat in the middle instead of running parallel; the anterior chelipeds are a little shorter than Bate's figure represents them to be in the typical form of canaliculatus. Possibly the California forms will later be connected with braziliensis or canaliculatus, but it is best, I believe, at present to regard them as forming a distinct species. Collection California Academy of Sciences.

\section{Suborder STOMATOPODA.}

Carapace small, leaving the last three or four segments of the thorax uncovered. Rostrum separated from the carapace by a movable joint. Eye-peduncles situated like the antenuules on a movable segment. First five pairs of thoracic appendages not biramous, the second pair large and chelate, last three pairs biramous and gressorial. Abdomen large, generally depressed; the first five pairs of pleopods with external gills. Uropods large and forming with the telson a strong tail-fin.

\section{Genus Pseudosquilla Dana.}

Abdomen smooth and strongly convex above, the sixth segment not fused with the telson. Telson with well developed submedian spines 
with movable tips, and one to four intermediate denticles between the submedian and intermediate spines. The dactyl of the large chelipeds is not strongly dilated at the base and has few or no marginal spines.

\section{Pseudosquilla Lessonii (Guerin).}

Squilla Cerisii Goerin, Voy. Coquille, Crust., 1830, p. 40 (S. Lessonii on plate).

Squilla spinifrons Owen, Proc. Zool. Soc. London, 1832, p. 6.

Squilla Lessonii Milne-Edwards, Hist. Nat. Crust., Tome II, 1837, p. 527.

White, List. Crust. Brit. Mus., 1847, p. 84.

Squilla monoceros Milne-Edwards, Hist. Nat. Crust., Tome II, 1837, p. 526. Nicolet in Gay's Hist. Chile, III, Crust., 1849, p. 224.

Pseudosquilla Lessonii Dana, Crust. U. S. Expl. Epd., Part 1, 1852, p. 662. Miers, Ann. Nat. Hist. (5), Vol. V, 1880, p. 113. Bigelow, Proc. U. S. Nat. Mus., Vol. XVII, 1894, p. 502.

Pseudosquilla marmorata Lockington, Proc. Cal. Acad. Sci., Vol. VII, 1877, p. 33.

Rostrum with acute outer angles and a long, median spine. Hand with three marginal spines; finger with two spines near the base. Sixth abdominal segment with four longitudinal carinæ which end posteriorly in spines. Telson with a median carina which ends posteriorly in a spine and five smaller carinæ on either side; the posterior margin has three large spines on either side of the triangular, median notch; two spinules between the submedian spines and the next large spine in front; a single spinule between the following pair of large spines. Basal prolongation of the uropod ending in one large spine with two spines on its inner margin; outer margin of the outer ramus of the uropods armed with spines which increase in size posteriorly, the last spine much exceeding the preceding ones.

Chili, S. lat. $00^{\circ} 46^{\prime}$; W. lon. $89^{\circ} 42^{\prime \prime}$; Wilmington, Calif. (Bigelow); Lower California; San Diego (Lockington)! Santa Catalina Island!

\section{Pseudosquilla stylifera (M.-Edw.).}

Gonodcictylus styliferus Milne-Edwards, Hist. Nat. Crust., Tome II, 1837, p. 530. Nicolet in Gay's Hist. Chile, III, Crust., 1849, p. 225.

Pseudosquilla stylifera Miers, Ann. Nat. Hist. (5), Vol. V, 1880, p. 112.

Bigelow, Proc. U. S. Nat. Mus., Vol. XVII, 1894, p. 502, fig. 3.

Rostrum longer than broad, acute, but not ending in a spine. Dactyl of the large chelipeds devoid of spines. Sixth abdominal segment longitudinally carinated. Telson with a median carina and a lateral one on 
either side; posterior margin with three large spines on either side of the median notch; a rounded denticle between the submedian and intermediate spines.

Chili; San Pedro (Bigelow); Santa Catalina Island! Point Mendocino, Calif.!

\section{Suborder SCHIZOPODA.}

Carapace rather small and generally not covering all the segments of the thorax. Eyes stalked. Mandibles generally furnished with an elongated palp. Maxillipeds similar to the succeeding appendages of the thorax which are furnished with well developed exopods. Ova carried beneath the thorax, with or without marsupial plates. Tail-fin well dereloped.

\section{Family MYSID $\approx$.}

Carapace small and membranaceous. Pereopods generally of similar form and slender. Branchiæ entirely absent. Females with a marsupial pouch. Pleopods generally rudimentary in the female and often so in the male. Inner ramus of the uropods usually furnished with an auditory organ.

\section{Genus Mysis Latr.}

Body slender. Antennal scale setose on both sides and not ending in a spine. Thoracic legs with the propodi subdivided. Fourth pair of pleopods in the male with the outer ramus greatly elongated; third pair of pleopods generally unlike those of the female, the remaining pairs simple and rudimentary as in the other sex.

Type.-M. oculata FABR.

\section{Mysis costata, sp. nov. Pl.II, $1.70-72$}

Rostrum broadly triangular, éfling in a spine. Ocular peduncles short, stout, and slightly flattened horizontally. First joint of the antennular peduncle about one-half longer than wide; second joint very short; outer flagellum about twice as long as the inner one and furnished with a few long setr near the base; the sensory organ of the male is well developed and furnished with a large, dense tuft of long curved hairs. Peduncle of the antennæ reaching about to the middle of the acicle but not reaching the tip of the peduncle of the antennules; second joint with a spine 
external to the base of the acicle; acicle narrow, tapering slightly towards the narrowly rounded tip and ciliated on both margins. Trunk of the mandibles very short and thick; penultimate joint of the palp widest a short distance from the base, whence it tapers to the distal end; second joint narrow, shorter than the preceding one, thickly setose, and having a large, curved, claw-like seta at the tip. The three pairs of maxillipeds end in a claw, the last joint of the third pair five-jointed; the propodi of the succeeding thoracic appendages are 5-7-jointed and end in a claw. Pleopods of the female simple and rudimentary. First three pairs of pleopods in the male simple and rudimentary, as in the female, and of similar form and nearly equal size; fourth pair with the exopod long, slender, smooth and curved, extending backwards beyond the tip of the sixth abdominal segment, the endopod short and furnished with long; plumose setæ; fifth pair of pleopods similar to, but slightly longer than the first three pairs. Telson very narrowly triangular, channeled above, and tapering to the narrow tip which is armed with strong spines; the margins are armed with strong spines, between which are several smaller ones. Inner caudal lamella narrow, widened at the base where the auditory organ is situated, rounded at the tip, and about equalling the telson; outer lamella about one-fourth longer than the inner one. The first abdominal segment is crossed with three and the following segments with two transverse ridges; first ridge on the sixth segment with a prominent median spine, second ridge with a pair of small median spines, and at the posterior margin of the segment there is a small median spine with a rounded lobe on either side. Two pairs of marsupial lamellæ.

Length, $10 \mathrm{~mm}$.

Numerous specimens taken in a tow net at San Pedro, Calif., July, 1896.

Collection University of California.

\section{Genus Neomysis Czerniavsky.}

Very closely allied to Mysis, from which it differs in having the long, narrow, antennal scale, which is setose on both margins, end in a sharp spine.

Type.-N. vulgaris (THOMPSON).

\section{Neomysis mercedis Holmes.}

Neomysis mercedis Holmes, Proc. Cal. Acad. Sci. (2), Vol. VI, 1897, p. 199, P1. XIX, figs. 1-10.

Rostrum rounded. Acicle narrow, elongated, tapering gradually to an acute tip, and furnished with thickly set, plumose setæo on both margins. 
The distal portion of the thoracic legs is divided into S-10 setiferous articulations, the last joint furnished with a claw. In the fourth pair of pleopods in the male the endopod reaches about to the middle of the slender, elongated exopod; terminal joint of the exopod short and bearing two large, sparingly plumose setro at the tip. Telson triangular, tip slightly emarginate, margins armed with several spines. Inner ramus of the uropods widened at the base and tapering to an acute tip which reaches beyond the telson; outer ramus much longer than the inner one, the sides subparallel to the rounded tip.

Almost colorless, with the exception of several large, irregularly branching pigment spots.

Lake Merced, Calif. Collected by Dr. H. P. Johnson.

\section{Neomysis franciscorum, sp. nov.}

Anterior margin of the carapace produced forwards into a wide quadrate lobe with a straight anterior margin and rounded angles. A strong spine at the antero-lateral angles of the carapace, above which the margin is concave. Eye-peduncles large and pyriform. Antemnular peduncle reaching about one-third the length of the acicle. First joint of the antennæ with a spine at the antero-external angle; peduncle one-fourth the length of the acicle, which is very narrowly lanceolate and ciliated on both margins. Epistome produced anteriorly into a spine. Last joint of the mandibular palp narrow and somewhat shorter than the preceding one which is much widened. Thoracic legs similar, the propodi divided into from ten articulations in the first, to fourteen in the last pair. All the pleopods in the female short and simple. Telson narrow, concave above, and tapering evenly to a point, the margins armed with numerous spines. Inner uropods narrow, tapering to an acute tip, and about equalling the telson.

Length, 1.25 in.; length of carapace, $\frac{5}{16} \mathrm{in}$; of telson, $\frac{5}{16} \mathrm{in}$.

\section{A single specimen taken in San Francisco Bay.}

This species is closely allied to Neomysis Rayii (Murdoch) from Point Barrow, but differs in having the telson acute instead of "truncated," and in having the terminal portions of the thoracic legs divided into a greater number of articulations. Collection University of California. 


\section{Genus Callomysis Holmes.}

Carapace with rounded angles and a deep posterior emargination. Antennal scale oblong, the outer margin naked and ending in a spine; inner and distal margins ciliated. Distal portions of the thoracic legs divided into numerous articulations. Pleopods in the female rudimentary but biramous; pleopods in the male short and small except the third pair, the outer ramus of which is much elongated. Telson armed with lateral spines and having a spinous emargination at the tip.

Type.-C. maculata Howmes.

\section{Callomysis maculata Holmes.}

Callomysis maculata HoLmes, Proc. Cal. Acad. Sci. (2), Vol. IV, 1895, p. 582, Pl. XXI, figs. 37-44.

Rostrum subtriangular. Last joint of the peduncle of the antennæ about as wide as long; acicle oblong, shorter than the peduncle, the tip truncated. Maxillipeds (first thoracic appendages) with the exopod longer than the endopod, the terminal portion divided into about fifteen articulations; the following pair of appendages much like the preceding but with a longer exopod; the endopods of the remaining pairs are longer than the exopods and have the terminal portion divided into 10-13 articulations. Pleopods rudimentary in the female, the rami of the first pair subequal; in the following pairs the outer ramus is minute. In the male the inner rami are shorter than the onter, the exopod of the third pair very long and slender; fourth and fifth pairs subequal and a little shorter than the first two pairs. Telson oblong, the sides armed with about eight strong spines; apical emargination with several slender spines. Uropods subequal and scarcely exceeding the telson. Nearly transparent, with large black pigment spots having numerous, irregularly branching radiations.

Length, $15 \mathrm{~mm}$.

Trinidad, Calif.; taken on a sandy beach in which the animals burrow as the waves recede. The females taken in June had their marsupial pouches filled with eggs or larvæ.

\section{Genus Heteromysis Smith.}

Body comparatively short. Carapace emarginate behind, not covering all the segments of the thorax. Eyes small. Antennal scale small, lamelliform, with both margins setose. Third maxillipeds much larger than 
the following appendages, propodal joint entire and spinous, terminal joint unguiform; the remaining legs slender, the terminal portion multiarticulate and devoid of a claw. Pleopods in both sexes small, simple, and similar. Telson deeply cleft at the apex.

Type.-H. formosa Sмiтн.

\section{Heteromysis odontops Walker.}

Heteromysis odontops WALKER, Trans. Liverpool Biol. Soc., Vol. XII, 1898, p. 278, Pl. XV, figs. 3-6; Ann. Mag. Nat. Hist. (7), Vol. II, 1898, p. 276.

Body rather slender; rostrum subacute. Eyes stout, with a tooth on the distal eud of the anterior margin of the peduncle. Legs behind the second pair with a terminal segment divided into eight articulations. Telson with the lateral margins slightly concave and armed with about twenty-four spines which extend over the whole length; tip of the telson with a deep, narrowly triangular cleft whose sides are armed with about thirty rather long spines. Inner uropod "considerably shorter than the outer, with four spines at the proximal end of the inner margin." The inner margin of the antennal acicle is figured as devoid of setæ-a character in which this species differs from the next.

Puget Sound.

\section{Heteromysis spinosus, sp. nov. Pl.IV, f. $73-76$.}

Body quite robust and somewhat depressed. Rostrum triangular, acute. First and third joints of the antennular peduncle of subequal length; second joint very short, the inner side longer than the outer; sensory organ represented by a minute papilla; inner flagellum short, not one-half the length of the outer one. Antennal scale small, oblong-oval, ciliated on both sides and at the rounded extremity; peduncle reaching about to the tip of the acicle, the last joint about three-fourths the length of the preceding one; flagellum about equal to the outer flagellum of the antennules. Trunk of the mandibles short and strongly curved; first joint of the palp very short, second loug, curved; the third joint much narrower and much shorter than the preceding one. Third maxillipeds large and stout, the penultimate joint with three pairs of spines on the inner mar. gin; claw strong and curved. The succeeding thoracic appendages are slender; the terminal portions divided into 8-10 articulations and ending in a slender claw. The pleopods are uniramous, rudimentary, and of similar form. Telson triangular, with a deep, triangular, terminal notch, 
the margins of which are closely set with small spinules; sides of the telson armed with spinules throughout their length. Inner caudal lamella about three-fourths the length of the outer one, but much longer than the telson and scarcely widened at the base where the small auditory organ is located. Both lamellæ are strongly ciliated and rounded at the tip.

Length, one-half inch.

\section{A single specimen taken at San Pedro, Calif., June, 1896. \\ Collection University of California.}

\section{Genus Mysidopsis Sars.}

Carapace comparatively small and not covering all the thoracic segments. Antennal scale lanceolate, setose on both edges, with a short apical articulation. First and second thoracic appendages powerfully developed; legs unequal, comparatively short and stout, the propodal joint divided into three articulations, the terminal one having a slender setiform claw. Pleopods in the male all natatory. Telson comparatively short, the apex entire or cleft.

Type.-M. didelphys (NoRMaN).

\section{Mysidopsis elongata, sp. nov. pe. IE. 6 : $77-80$}

A small, slender species with a long, narrow, somewhat depressed abdomen. Rostrum rounded. Eye-peduncles reaching about to the middle of the antennal scale. In the stout antennular peduncle of the male the first joint is nearly as wide as long, the second joint much wider than long, and the third somewhat longer than wide and furnished with a well developed sense organ below and a foliate appendage on the inner side. In the more slender peduncle of the female the first joint is over twice as long as wide, the second longer than broad, the third nearly as long as the first and devoid of the appendage found in the male; the inner flagellum in both sexes is shorter than the outer one, which does not attain half the length of the body. Antenu» short, the acicle narrow, tapering, but not ending in a spine, and having both edges fringed with plumose setæ; peduncle slender and about two-thirds the length of the acicle. The pleopods of the female are small, slender and uniramous, while those of the male are'large, biramous, and of similar form. Sixth abdominal segment about as long as the two preceding ones combined. Telson not one-half as long as the preceding segment and not reaching beyoud the middle of the inner ramus of the uropods; its general form is triangular, but the sides converge more strongly in the basal half; the tip is broadly rounded and 
ar'med with numerous, short, closely set spinules, which do not extend in front of the posterior third of lateral margins. The inner rami of the uropods are shorter than the sixth abdominal segment, somewhat widened at the base where the auditory organ is situatel, behind which the sides are nearly parallel to the abruptly rounded tip; outer ramus narrow, about . one-half longer than the inner one and abruptly rounded at the end.

Several specimens caught at San Pedro, Calif., by Dr. H. P. Johnson, December 29, 1895. Collection University of California.

\section{Genus Siriella Dana.}

Carapace small, rostrate. Eyes normal. Antennal scale with the onter margin naked and produced distally into a spine. Legs subequal, the propodi entire or only two-jointed and furnished with a transverse row of setro on either side of the stroug, sharp, falciform claw. Pleopods rudimentary in the female, larger and biramous in the male and often furnished with two spirally twisted appendages at the base of the inner ramus. Outer ramus of the uropods larger than the inner, having an imperfect articulation near the tip, and the outer margin armed with spines. Telson elongated, the margins spinous and the apex entire. Auditory organ well developed.

The species of this genus are mostly pelagic and many of them have a very wide range.

\section{Siriella pacifica, sp. nov.}

Rostrum triangular, acute. Eyes large. Peduncle of the antennules reaching nearly to the tip of the antennal scale, the first joint larger than the next two and concave above; second joint wider than long and bearing two large plumose setro at the distal end; third joint about twice as long as wide, with a single, large plumose seta near the middle of the inner margin and several similar setro at the tip; inner flagellum about two-thirds the length of the outer. Antennal scale oblong, the straight outer margin ending in a spine; distal margin rounded, produced beyond the outer spine, and furnished, like the inner margin, with long plumose setæ. Upper lip subcordate and produced at the anterior end into a long narrow spine. Propodi of the thoracic legs two-jointed with a transverse row of setre. at the distal end on either side of the base of the dactyl. Dactyls claw-like, tapering to a sharp, curved tip, and having a transverse or oblique row of setre at about the proximal third of their length. 
Pleopods in the male rather small. Telson narrow, channelled above, somewhat constricted behind the base, the sides gently rounded and tapering from near the middle to the narrowly rounded tip; the sides and tip armed with spines; three large spines on each margin of the slightly widened base, behind which is a short interval at the constriction devoid of spines, beyond which the margin is closely set with spines to the tip; two somewhat larger spines at the distal end between which are three very short spines and a pair of plumose setæ. Inner ramus of the uropods narrow, scarcely expanded at the base, distally rounded, slightly exceeding the telson, setose on both margins and furnished with strong spines along the inner side. Outer ramus larger and much wider than the inner, the outer margin armed with (10-14) spines which begin about the anterior fourth of its length and extend, gradually increasing in size, to the articulated portion, where the ramus is somewhat constricted and beyond which the margin is furnished with plumose setæ.

Length $11 \mathrm{~mm}$.

The color of several specimens preserved in formalin is white or a very pale pink. Pigment is scarce but on the posterior marsupial lamella of the females there is a pair of large, irregularly branched pigment spots, the two anterior lamellø haring each a single pigment spot.

Several specimens caught in a tow net at San Diego, Calif., October 15, 1898. A single female specimen taken at Santa Catalina Island, August 3, 1893. The marsupial pouch contained young embryos in specimens from both these localities.

Collection University of California.

This species resembles Siriella Thompsonii MilneEdwards, but may readily be distinguished by the twojointed propodi of the thoracic legs.

\section{Family EUPHAUSIID $Æ$.}

Carapace rather small, not calcareous. Brauchir arborescent, situated on the coxæ of the thoracic legs. Thoracic legs generally similar in form, the hinder pairs somewhat rudimentary. No marsupial lamellø. Pereopods well developed and natatory in both sexes. Inner ramus of the uropods devoid of an auditory organ. Telson long and slender, with two loug, spiniform appendages attached in front of the tip. 


\section{Genus Thysanoessa Brandt.}

Carapace rostrate, the antero-lateral angles produced. Eyes large, the peduncles short. Antennules with the first joint flattened and devoid of a dorsal, leaf-like appendage; flagella short. Maxillipeds slender and not greatly elongated. First pair of legs much longer than the rest; merus and carpus elongated; propodus compressed, the margins furnished with strong setro; last joint very short and setose. Penultimate pair of legs very small; endopod two-jointed. Last pair of legs quite rudimentary.

Type.-T. longipes BRANDT.

\section{Thysanoessa spinifera, sp. nov. Pl. LE, f.81.}

Rostrum lanceolate from a triangular base, carinated above, the carina extending back some distance upon the carapace. A prominent spine on either side of the base of the rostrum. A small spine a very short distance above the acute antero-lateral angle of the carapace which is produced forwards; a sinus between this angle and the spines at the base of the rostrum. Eyes large, nearly spherical, the cornea occupying most of the surface. Antennules stout, the first joint flattened, about reaching the tip of the rostrum, the antero-external angle armed with a small spine; second joint prismatic, about two-thirds the length of the first but a little longer than the third. Antenna scarcely half the length of the body, the last joint of the peduncle abont three-fourths the length of the third, and reaching nearly to the tip of the acicle; acicle narrowly oblong, the sides nearly parallel, the tip reaching the tip of the second basal joint of the autennules; outer margin slightly coucave, ending distally in a spine; inner margin slightly convex and furnished with long setr; the distal end is broadly rounded, transverse, and furnished with setro like the inner margin. Mandibles stout; terminal joint of the palp oblong-elliptical, the inner margin setose, the setæ increasing in length towards the tip, the terminal seta long and stout. Maxillipeds moderately long; first joint of the endopod short and tapering distally; second joint elongated, slender, about as long as the following joints combined; third joint longer than the fourth; last joint tapering, about three-fifths the length of the preceding one, the tip bearing a very long seta. First pair of legs (gnathopods) comparatively short for the genus, exopod two-jointed, the first joint not reaching the tip of the first joint of the endopod; second joint of the endopod slender and elongated, furnished with fine cilia on one margin; third joint furnished distally. with long setæ and about as long as the two following joints combined; fourth joint with both margins furnished with strong setæ; terminal joint very short, furnished with four or five large setæ and several smaller ones. Second pair of legs with the 
exopod reaching the tip of the first joint of the endopod; third joint of the endopod about equalling the two following; last joint about one-fourth the length of the preceding one. The four succeeding pairs of pereopods are similar to the first but decrease successively in length posteriorly. The penultimate pair of pereopods is very small; the endopod is twojointed, the tip of the first joint nearly reaching the tip of the exopod. The last pair of pereopods is probably represented by a minute styliform appendage on the last tuft of branchiæ. Abdomen slender, the lateral angles acute, the first five segments carinated above, the carinn on the fourth and fifth segments ending posteriorly in a long spine; sixth segment rounded above but ending posteriorly in a small spine which is curved downwards. Telson long, deepiy channelled above, the anterior fourth with the sides nearly parallel, the posterior portion tapering to the acute tip; subapical spines extending beyond the tip; a pair of marginal spines near the middle of the dorsal surface and another pair above the bases of the subapical spines. Uropods subequal to the telson, the inner ramus narrowly lanceolate; outer ramus much broader and slightly longer than the inner, the outer angle subacute.

Length, $30 \mathrm{~mm}$.

Taken near Fort Bragg, Calif., June, 1894.

This species may be distinguished from $T$. longipes Brandt by its more slender rostrum, differently shaped antennal scale, by having the third basal joint of the antennules shorter, instead of longer than the second, and in having the first pair of pereopods considerably shorter. The corneæ are nearly round and not divided by a constriction into an upper and a lower portion as in T. gregaria and macroura described by Sars.

Collection University of California.

\section{Thysanoessa gregaria Sars.}

Thysanoessa gregaria SARs, Forhandl. Vidensks. Selsk., Christiania, No. 7, 1883; Challenger Reports, Vol. XIII, 1885, p. 120, P1. XXI, figs. 8-17; Pl. XXII, figs. 1-30.

Rostrum large, triangular; acute; antero-lateral angle of the carapace produced into a sharp, triangular process; lower margin of the carapace with a small tooth behind the middle. Eyes very large, subglobose, the upper part of the large cornea constricted; an incision between the smaller 
upper portion of the cornea and the peduncle. First basal joint of the antennules elongated, flattened, and armed with a spine at the anteroexternal angle; second and third joints of subequal length; flagella shorter than the peduncle. Second basal joint of the antennæ longer than wide, with a slender spine at the antero-external angle; third joint very short; last two joints very slender, the terminal one not quite reaching the tip of the narrow acicle. Legs short, diminishing in length posteriorly, the first pair much longer than the others, and geniculated, the terminal joint very short. Abdomen smooth above, none of the segments produced into spines. Telsoin very narrow, the apex acuminate, the subapical spines smooth and reaching a short way beyond the tip; dorsal surface with two pairs of small spines. Inner ramus of the uropods very narrow and about reaching the tip of the telson; outer ramus broader and somewhat shorter than the inner, the postero-external angle acute. Preanal spine in the form of a broad plate, the posterior margin of which is armed with spmules.

Length, $18 \mathrm{~mm}$.

Numerous specimens taken in tow at Avalon, Santa Catalina Island, August 13, 1893.

This is a pelagic species and is very extensively distributed in the Atlantic and Pacific oceans, both north and south of the equator. 



\section{APPENDIX.}

A few species have recently been reported as occurring in the area covered by this paper which have not been mentioned in the preceding pages. Some new species also have been added, and certain changes made in nomenclature after the proof of most of the paper had been corrected and returned. For the sake of completeness a short account of these contributions is given in the following notes.

\section{Philyra pisum De Haan.}

Philyra pisum De HaAN, Fauna Japonica, Crust., 1850, p. 131, Pl. XXXIII, fig. 7. Oktmann, Zool. Jahrb. Abth. f. Syst., Bd. VI, 1892, p. 582, Pl. XXVI, fig. 16. Calman, Ann. N. Y. Acad. Sci., Vol. XI, No. 13, 1898, p. 262.

This species has been recently reported from Puget Sound by Calman. "A single male specimen," says Calman, "lacking both chelipeds and some of the ambulatory legs, is referred to this species. I have been able to compare it with two specimens dredged in Yokohama Bay by Professor D'Arcy Thompson, and also with three specimens from the Strassburg Museumidentified by Dr. Ortmann (l. c.), and sent to us by the great kindness of Professor L. Döderlein, by whom they were collected in the same neighborhood. The resemblance in both cases is so exceedingly close that in spite of the imperfection of the Puget Sound specimen I have no hesitation in adding $P$. pisum to the list of species inhabiting both sides of the North Pacific." 


\section{Pagurus Middendorffii Brandt.}

Pagurus (Eupagurus) Middendorffi BRANDT, Middendorff's Siberische Reise, Bd. II, Th. 1, 1851, p. 108, Pl. V, figs. 1-16.

Eupagurus Middendorffi Stimpson, Journ. Bost. Soc. Nat. Hist., Vol. VI, 1857, p.482; Proc. Acad. Nat. Sci. Phila., 1858, p. 250. Calman, Ann. N. Y. Acad. Sci., Vol. XI, No. 13, 1898, p. 260.

This species has recently been reported from Puget Sound by Calman. It was reported by Brandt from Okhotsk Sea and Sitka, Alaska, and later by Stimpson from Japan.

\section{Pagurus splendescens Owen.}

Pagurus splendescens Owen, Zoölogy Beechy's Voyage, 1839, p. 81, Pl. $\mathrm{XXV}$, figs. 1 and $1 a$.

Eupagurus splendescens Calman, Ann. N. Y. Acad. Sci., Vol. XI, No. 13, 1898, p. 260.

This species also has been found by Calman to range as far south as Puget Sound. It is quite different from the other species of Pagurus here described. The carapace is very short and broad and much harder than in the other species, the whole surface being "granulate, much resembling the back of a toad." The front is tridentate and the rostrum is very long, reaching beyond the middle of the short, stout eye-stalks. The anterolateral angles of the branchial regions are produced forwards into a prominent process. The antennæ are longer than the chelipeds and the acicle is acute and "notched along the upper part." The chelipeds are elongated, very unequal in size, hirsute and granulate below; "above they/bear long rows of small tubercles and reflect hues of green and gold with metallic lustre; a pink hue is also reflected in some positions." Dactyls of the left hand long and curved downwards. Ambulatory legs longer than the chelipeds, the dactyls twisted. Kamtschatka (Owen). 


\section{Spirontocaris spinus (Sowerby).}

Cancer spinus Sowerby, Brit. Misc., 1806, p. 47, Pl. XXI.

Hippolyte spizus Owex, Appendix to Ross's Second Voyage, 1835, p. lxxxiii; Pl. III, fig. 2.3

Spirontocaris spinus BATE, Challenger Reports, Vol. XXIV, 1888, p. 596, Pls. CVI and CVII.

For further references and synonyms, see BATE, l. c.

A short, robust species. Rostrum beginning at the posterior end of the carapace as a carina, which is strongly arched and armed with four or five large teeth; the lamina or rostrum proper is high, much shorter than the carapace, more or less truncated at the tip, and armed above with several teeth which decrease in size auteriorly; lower side strongly curved distally and armed with one or more teeth. Two snpra-orbital teeth on either side, the posterior one the larger. A prominent antennal spine and a smaller spine at the antero-inferior angle of the carapace. Outer spine at the base of the antenuules large, about reaching the tip of the third joint of the peduncle. Acicle extending beyond the rostrum. Maxillipeds stout, exceeding the rostrum, the terminal joint flattened, about four times the length of the preceding joiut, the tip armed with spines; exognath not reaching the tip of the antepenultimate joint. First pair of chelipeds rather slender. Third carpal joint of the second pair longer than the first and second combined, but not twice as long. Dactyis of the ambulatory legs short and spiny below. Third segment of the abdomen produced backward into a prominent beak.

This species has been reported from very near our limits, and as it is very closely allied to S. lamellicornis (Dana), and will probably be found to occur along with that species, this description is inserted in order to distinguish the two forms. I have not seen any representatives of S. spinus from the Pacific coast, but Dana's description and figures of lamellicornis agree quite closely with specimens of spinus that I have from the north Atlantic. It is possible that the so-called western representatives of spinus belong to Dana's species, for the differences between the two forms are not greater than those often found between widely separated members of an extensively distributed species. The third joint of the carpus of the second pair of chelipeds is somewhat 
larger in lamellicornis than in spinus, and the rostrum is also larger. The chief difference, however, between the two species seems to be in the dactyls of the ambulatory legs; in spinus they are rather stout and strongly spiny below, while in lamellicornis they are more slender and nearly devoid of spines, having only a few minute spinules near the base.

\section{Spirontocaris grœnlandica ( $F a b r$.}

Astacus gronlandicus FABRICIUs, Syst. Ent., 1775, p. 416.

Hippolyte gronlandica MIERs, Anu. Nat. Hist. (4), Vol. XX, 1877, p. 62.

Sм ттн, Rep. Prog. Geol. Sur. Canada, 1878-9, B, p. 214; Trans. Conn.

Acad. Sci., Vol. V, 1880, p. 85, Pl. X, fig. 2. Calman, Ann. N. Y.

Acad. Sci., Vol. XI, 1898, p. 260.

Spirontocaris grcenlandica WALKEK, Trans. Liverpool Biol. Soc., Vol. XII, 1898, p. 276.

This species, which has previously been mentioned as having been reported by Professor S. I. Smith from Queen Charlotte's Islands, has been found both by Walker. and by Calman to occur in Puget Sound. The carina on the carapace extends about to the posterior margin and is armed with four large teeth; the rostrum is short and very slender, scarcely higher than wide, and projects nearly straight in front; the upper margin is armed with from two to four spines, the lower with two or three. Maxillipeds robust, exceeding the acicle. Anterior chelipeds stout. Ambulatory legs rather stout, spiny, the dactyls short and spiny below. Sides of the segments of the abdomen acute.

I have not seen western representatives of this species.

Miss M. J. Rathbun has recently made Lophoxanthus bellus (Stimpson) the type of a new genus Lophopanopeus, ${ }^{1}$ in which are included also Lophoxanthus leucomanus (Lockington) and $L$. frontalis (Rathbun). In

1 Bull. Lak. Nat. Hist. State Univ. Iowa, 1898, p. 272. 
her key to the Cyclometopa of North America ${ }^{1}$ Miss Rathbun gives the names of three new species of Lophopanopeus from the Pacific coast, Lophopanopeus Lockingtoni and diegensis from San Diego, Calif., and L. Heathii from Monterey. Fuller accounts of these species, it is stated, are soon to appear in the Proceedings of the United States National Museum. Lophopanopeus Heathii has the carpus of the chelipeds smooth, or nearly so, as in frontalis, but the color of the pollex does not extend back upon the hand. Diegensis and Lockingtoni have the carpus very rough as in leucomanus. Lockingtoni is said to be distinguished from leucomanus and diegensis by the slightly bilobed carpal joints of the ambulatory legs; diegensis has the carpus of the chelipeds covered with tubercles and not with reticulating ridges as in leucomanus.

$\dot{A}$ new species of Cancer, C. Jordani from Monterey, is also announced in the same paper. In this species the fronto-orbital width is nearly half the width of the carapace. The carapace is slightly areolated and the antero-lateral teeth are strong and projecting. The carpus of the chelipeds has two spines at the inner angle, the one above the other. Cancer Anthonyi is reported in the key from the region between Monterey and San Diego; it was originally described from Playa Maria Bay, west coast of Lower California. ${ }^{2}$ Miss Rathbun does not recognize the genus Trichocarcinus as distinct from Cancer.

Reference may be made to two articles contributed by Prof. J. S. Kingsley to the "Synopses of North American Invertebrates," published by the American Naturalist. ${ }^{3}$ The first article consists of a key to the species of

\footnotetext{
${ }^{1}$ American Naturalist, Vol. XXXIV, Feb., 1900, p. 131.

2 Proc. Biol. Soc. Washington., Vol. XI, 1897, p. 111

${ }^{3}$ American Naturalist, Sept. and Oct., 1899.
} 
Caridea of North America. The species occurring within or near our limits of which figures are given are the following: Alpheus aqualis (=Harfordi); Caridina pasadenoe; Crangon boreas; Crangon munitellus; Crangon munitus; Crangon franciscorum; Hippolyte affnis; Hippolyte californiensis; Hippolyte Gaimardii; Hippolyte Layi; Hippolyte Phippsii; Hippolyte polaris; Heptacarpus brevirostris, Herdmani and palpator (as Hippolyte); Hippolysmata californica; Palomon Ritteri; Pandalus Dano; Pandalus pubescentulus; Paracrangon echinatus; Syncaris pacifica (as Acanthephyra). The large cheliped of Alpheus Candei is figured, but whether the specimen from which the figure was drawn came from the eastern or western coast of North America is uncertain. The figure resembles the cheliped of Alpheus clamator, and may have been taken from a specimen of that species (see p. 184).

The species here described as Syncaris pacifica is placed by Kingsley in the genus Acanthephyra. The type of Acanthephyra, viz., A. armata A. Milne-Edwards ${ }^{1}$ is, however, a marine species belonging properly to a different family from that which includes Syncaris. In $A$. armata the abdomen is carinated and the rostrum extends back as a carina upon the carapace; there is no supraorbital spine, and the mandible is provided with a twojointed palp. In Syncaris neither the carapace nor the abdomen is carinated, a supra-orbital spine is present, and the mandible, as in the other genera of the Atyidæ, is devoid of a palp.

The second article consists of a key to Astacoid and Thallassinoid Crustacea. Figures are given of the chelipeds of Upogebia pugettensis, Callianassa gigas, longimana and californiensis.

${ }^{1}$ Ann. Sci. Nat. (6), T X1, 1881, Art. No. 4, p. 12. 


\section{BIBLIOGRAPHY.}

1852. Agassiz, L. Communication on Cambarus Gambelii. Proc. Acad. Nat. Sci. Phila., Vol. VI, p. 375,

1864. Bate, C. SPexce. Characters of New Species of Crustaceans Discovered by J. K. Lord on the Coast of Vancouver Island. Proc. Zool. Soc. London, 1864, p. 661 .

1865. Ann. Nat. Hist., (3), Vol. XV, p. 485.

1865a. - Vancouver Island Crabs, in J. K. Lord's Naturalist in Vancouver's Island and British Columbia, Vol. II, p. 262.

18s8. - Report on the Macroura. Challenger Reports, Vol. XXIV.

1841. Bell, Thos. On the Crustacea of the Coasts of South America. Trans. Zool. Soc. London, Vol. II, p. 39.

1853. - British Stalk-eyed Crustacea, London.

1855. Horæ Carcinologicø: A Monograph of the Leucosoidea. Trans. Linn. Soc. London, Vol. XXI, p. 277.

1892. Benedict, J. E. Preliminary Descriptions of Thirty-seven New Species of Hermit Crabs of the Genus Eupagurus in the U.S. National Museum. Proc. U. S. Nat. Mus., Vol. XV, p. 1.

1892. Corystoid Crabs of the Genera Telemessus and Erimacrus. Ibid., p. 223.

1894. Descriptions of New Genera and Species of Crabs of the Family Lithodidæ, with Notes on the Young of Lithodes camtschaticus and Lithodes brevipes. Ibid., Vol. XVII, p. 479.

1891. Benedict, J. E. and Rathbur, M. J. The Genus Panopeus. Proc. U.S. Nat. Mus., Vol. XIV, p. 355.

1893. Bigelow, R. P. Preliminary Notes on the Stomatopoda of the "Albatross" Collections and on Other Specimens in the National Museum. Johns Hopkins Univ. Circulars, No. 106, p. 100.

1594. - Report upon the Crustacea of the Order Stomatopoda Collected by the Steamer Albatross between 1885 and 1891 and on Other Specimens in the U.S. National Museum. Proc. U.S. Nat. Mus., Vol. XVII, p. 489.

1880. Boas, J. E. V. Studier over Decapodernes Sloegtskabsforhold. Vid. selsk. Skr., 6 Rokke, Natur. og Math., Afd. 1, p. 2.

1S92. Bouvier, E. L. Paguriens recueillis par M. Dignet, sur le littoral de la Basse Californie. Bull. Soc. philomath. de Paris, (8), Tome V, p. 18.

1894. Recherches sur les affinités des Lithodes et des Lomis avec les Paguridés. Ann. Sci. Nat. (7), Tome XVIII, p. 157.

1895. - Sur une Collection des Crustacés décapodes recueillis en Basse-Californie par MI. Diguet. Bull. du Mus. d'histoire naturelle, No. 1, pp. 6 and 159. Paris. 
1895. - Sur la distribution géographique des Crustacés de la sous famille des Lithodinés. Ibid., No. 2, p. 70.

1895. - Sur les Palémons recueillis dans les eaux douces de la BasseCalifornie. Ibid., No. 4, p. 159.

1896. - Sur la Classification des Lithodinés et sur leur Distribution dans les Océans. Ann. Sci. Nat. (8), Tome I, p. 1.

1848. Brandt, J. F. Die Gattung Lithodes Latreille nebst vier neuen ihr verwanten von Wossnessenski entdecten, als Typen einer besondern Unterabtheilung (Tribus Lithodea) der Edward'schen Anomouren. Bull. phys.-math. Acad. St. Petersbourg, Tome VII, No. 11, p. 171, June 29.

1848. Vorlänfige Bemerkungen ìber eine neue, eigenthümliche, der Fauna Russland's angehörige Gattung oder Untergattung von Krabben (Crustacea Brachyura) aus der Edward'schen Abtheilung der Corysten [Platycorystes.] Ibid., Tome VII, p. 177, July 12.

1850. Bericht iiber die für die Reisebeschreibung des Hrn. von Middendorff von J. F. Brandt bearbeiteten Krebsthiere aus den Abtheilung der Brachyuren (Krabben), Anomouren und Makrouren (Krebse). Ibid., Tome VIII, p. 234; also in Mélanges biol., Tome 1, p. 49, Jan. 28.

1850. Vorläufige Bemerkungen über eine neue aus zwei noch unbeschriebenen Gattungen und Arten gebildite Unterabtheilung (Hapalogastrica) der Tribus Lithodina, begleitet von einer Characteristik der eben genannten Tribus der Anomouren. Ibid., Tome VIII, p. 266, Feb. 13; also in Mélanges biol., Tome I, p. 54 .

1851. Krebse, in Middendorff's Siberische Reise, Bd. II, Th. 1, p. 79.

1853. Ueber eine neue Art der Gattung Cryptolithodes (C. sitchensis). Bull. phys.-math. Acad. St. Petersbourg, Tome XI, p. 254.

1886. Brooks, W. K. Report on the Stomatopoda. Challenger Reports, Vol. XVI.

1898. Calman, W. T. On a Collection of Crustacea from Puget Sound. Ann. N. Y. Acad. Sci., Vol. XI, p. 259.

1860. Cooper, J. G. Report on the Crustacea Collected on the Survey. Reports of Explorations and Surveys for a Railroad Route from the Mississippi River to the Pacific Ocean, Vol. XII, Book 2, p. 387.

1899. Coutiere, H. Les "Alpheid»". Ann. Sci. Nat. (Zool.), 8th Ser., Tome IX, p. 1.

1851. Dana, James D. Conspectus Crustaceorum quæ in Orbis Terrarum Circumuavigatione, * * * lexit et descripsit J. D. Dana. Am. Journ. Sci. (2), Vol. XI, p. 268.

1851-52. Conspectus etc., continued. Proc. Acad. Nat. Sci. Phila., Vol. V, p. 247, and Vol. VI, pp. 6 and 73. 
1552. Crustacea of the U. S. Exploring Expedition. U. S. Exploring Expedition, Vol. XIII, Part 1.

1Să4. Catalogue and Description of Crustacea Collected in California by Dr. John L. Le Conte. Proc. Acad. Nat. Sci. Phila., 1854, p. 175.

1554. Description of a New Species of Cryptopodia from California. Am. Journ. Sci. (2), Vol. XVIII, p. 430.

1846. Errchsox, W. F. Uebersicht der Arten der Gattung Astacus. Wiegmann's Archiv für Naturgeschichte, Bd.,XII, pp. 86 and 375.

1S85. Faxos, Walter. List of the Known Species of Cambarus and Astacus. Proc. Am. Acad. Arts, and Sci., Vol. XX, p. 135.

1S55. A Revision of the Astacidro. Mem. Mus. Comp. Zool. Harard College, Vol. X, No. 4.

1S86. A List of the Astacidr in the U. S. National Mnseum. Proc. U. S. Nat. Mus., Vol. VIII, p. 356.

1890. Notes on North American Crayfishes. Proc. U. S. Nat. Mus., Vol. XII, p. 619.

1893. Preliminary Descriptions of New Species of Crustacea. Bull. Mus. Comp. Zool. Harvard College, Vol. XXIV, No. 6, p. 149.

1S95. —_The Stalk-eyed Crustacea. Mem. Mus. Comp. Zool. Harvard College, Vol. XVIII, p. 1.

1S96. - Supplementary Notes on the Crustacea. Bull. Mus. Comp. Zool. Harvard College., Vol. XXX, No. 3, p. 153.

1898. - Observations on the Astacidro in the United States National Museum and in the Museum of Comparative Zoology, with Descriptions of New Species. Proc. U. S. Nat. Mus., Vol. XX, p. 643 .

1856. Gerstaecker, C. E. A. Carcinologische Beiträge. Archiv für Naturgeschichte, Bd. XXII, p. 101.

1850. Gibbes, Lewis R. On the Carcinological Collections in the United States. Proc. Am. Ass. Adv. Sci., Vol. III, p. 167.

1859. Monograph of the Genus Cryptopodia. Proc. Elliott Soc. Charleston, S. C., Vol. I, p. 32.

185̄. Gibboss, W. P. On Ctenorhinus setimanus, New Genus and Species from the Farallones. Proc. Cal. Acad. Sci., Vol. 1, p. 48.

1S52. Grrard, C. A Revision of the North American Astaci. Proc. Acad. Nat. Sci. Phila., Vol. VI, p. 87.

1870. Hagen, H. A. Monograph of North American Astacidæ. Ill. Cat. Mus. Comp. Zool. Harvard College, No. 3.

1899. HAY, W. P. Synopses of North American Invertebrates. VI, The Astacidio of North America. Amer. Nat., Vol. XXXIII, p. 957.

1SSS. Hexdersor, J. R. Report on the Anomoura. Challenger Reports, Vol. XXVII. 
1782-1804. Herisst, J. F. W. Naturgeschichte der Krabben und Krebse.

1895. Holmes, S. J. Notes on Wost American Crustacen. Proc. Cal. Acad. Sci. (2), Vol. IV, p. 563.

1896. Description of a Now Schizopod from Lako Merced. Ibicl. (2), Vol. VI, p. 199.

1878-79. Huxcey, Tros. If On the Classification and Distribution of the Crayfishes. Proc. Zool. Soc. London; the same in Fronch in the Arch. Zool. Exp. et Gen., Tome VIII, p. 79.

1880. The Crayfish. International Science Series. New York.

1862. Kinaran, J. R. On the Brittanic Species of Crangon and Galathea, with Some Remarks on the Homologies of These Groups. I'rans. Roy. Irish Acad., Vol. XXIV, p. 45.

1864. Synopsis of the Species of the Families Crangonidio and Galatheidiv Which Inhabit the Seas around the British Isles. Proc. Roy. Irish Acad., Vol. VIII, p. 67.

1878. Krnasley, J. S. A Symopsis of the North Amerienn Species of the Genus Alphous. Bull. U. S. Geol. Sur. 'T'err. (Haydon), Vol. IV, No. 1, p. 189.

1878. - Notes on the North American Cariden in the Musoum of the Penbody Academy of Science at Salem, Mass. Proc. Acad. Nat. Sci. Phila., 1878, p. 89.

1878. - List of North American Crustacen belonging to the Suborder Carider. Bull. Essex Inst., Vol X, p. 50.

1879. - On a Collection of Crustacen from Virginin, North Carolina and Florida, with a Revision of the Genera of Crangonida and Paliomonidio. Proc. Acad. Nat. Sci. Phila., 1879, p. 383.

1880. Carcinological Notes: Revision of the Gelasimi. Ibid., p. 135.

1880. Carcinological Notes: Revision of the Genus Ocypoda. Ibid., p. 179.

1880. Carcinological Notes: Synopsis of the Grapsidw. Ibid., p. 187.

1881. - - Notes on North American Decapoda. Proc. Bost. Soc. Nat. Hist, Vol. XX, p. 145.

1883. - Carcinological Notes. Bull. Essex /nst., Vol. XIV, p. 105.

1899. —_ Synopses of North American Invertebrates. III, The Caridea of North America. Amer. Nat., Vol. XXXIII, p. 709.

1899. - Synopses of North American Invertebrates. IV, Astacoid and Thalassinoid Crustrcen. Ibid., p. 819.

1842. Kköyer, H. Monographisk fremstilling af slnogten Hippolytes Nordiske Artor. Coponhagen.

1829. Latrinlie, P. A. Crustacés in Cuvier's Regno Animale. 2 Ed., Tome IV. Paris.

1875. Lockington, W. N. On the Crustacen of California. Proc. Cal. Acad. Sci., Vol. V, p. 350. 
1877. - - Remarks on the Crustacea of the Pacific Coast with Descriptions of Some New Species. Ibid., Vol. VII, p. 28.

1877. - Description of Seventeen New Species of Crustacea. Ibid., Vol. VII, p. 41.

1877. - Description of a New Genus and Species of Decapod Crustacean. Ibid., Vol. VII, p. 55.

1877. Remarks on the Crustacea of the Pacific Coast of North America including a Catalogne of the Species in the Museum of the California Academy of Sciences. Ibid., Vol. VII, pp. 63-78, 94-108, 145-156.

1878. - Remarks on Some New Alphei, with a Synopsis of the North American Species. Ann. Nat. Hist. (5), Vol. I, p. 465.

1878. Remarks upon the Thalassinidea and Astacidea of the Pacific Coast of North America. Ibid. (5), Vol. II, p. 299.

1878. - Remarks upon the Porcellanidea of the West Coast of North America. Ibid. (5), Vol. II, p. 394.

1878. Notes on the Pacific Coast Crustacea. Bull. Essex Inst., Vol. $\mathrm{X}, \mathrm{p} .159$.

1877. MIERs, E. J. Report on the Crustacea collected by the Naturaiists of the Arctic Expedition in 1875-6. Ann. Nat. Hist. (4), Vol. $\mathrm{XX}, \mathrm{pp} .52$ and 96.

1877. On a Collection of Crustacea, Decapoda and Isopoda, chiefly from South America, with Descriptions of New Genera and Species. Proc. Zool. Soc. London, 1877, p. 653.

1878. - Revision of the Plagusiinæ. Ibid. (5), Vol. I, p. 147.

1878. - Notes on the Penæidæ in the Collection of the British Museum, with Descriptions of Some New Species. Proc. Zool. Soc. London, p. 298.

1879. - On a Collection of Crustacea made by Capt. H. C. St. John in the Corean and Japanese Seas. Ibid., p. 18.

1879. Revision of the Hippidea. Journ. Linn. Soc. London, Vol. XIV, p. 312.

1879. — On the Classification of the Maioid Crustacea, or Oxyrhyncha, with a Synopsis of the Families, Subfamilies and Genera. Ibid., Vol. XIV, p. 634 .

1880. - On the Squillidæ. Ann. Nat. Hist. (5), Vol. V, pp. 1 and 108.

1886. - Report on the Brachyura. Challenger Reports, Vol. XVII.

1862. Milne-Edwards, Alphonse. Monographie des Crustacés fossiles de la famille des Cancériens. Ann. Sci. Nat. (4), Tome XVIII, p. 31 .

1858-61. Études zoologiques sur les Crustacés récents de la famille des Portuniens. Archiv. du Mus. Hist. Nat. Paris, Tome X, p. 309 .

1865. Études zoologiques sur les Crustacés récents de la famille des Cancériens. Nouv. Arch. Mus. Hist. Nat., Tome I, p. 177. 
1870. - Révision du genre Callianassa (Leach) et description de plusieurs espèces nouvelles de ce groupe faisant partie de la collection du Musénm. Nouv. Archiv. Mus. Hist. Nat., Tome VI, p. 75.

1879. - Mémoire sur les Crustacés décapodes du genre Dynomène. Ann. Sci. Nat. (6), Tome VIII, Art. 3.

1881. ÉEtudes sur les Xiphosures et les Crustacés de la Région Mexicaine. Miss. Sci. au Mex., 5 partie, Tome I.

1894. Milne-Edwards A. Et Bodvier, E. L. Considérations générales sur la Famille des Galathéidés, Ann.Sci. Nat. (7), Tome XVI, p. 191.

1834-40. Milne-Edwards, Henri. Histoire Naturelle des Crustacés. Paris.

1852-53. Mémoire sur la famille des Ocypodiens. Ann. Sci. Nat. (3), Tome XVIII, p. 128, and Tome XX, p. 163.

1843. Mrlne-Edwards, H. et Lucas. Crustacés in D'Orbigny's Voyage dans l'A merique Mèridionale., Tome VI. Paris.

1884. Murdoch, J. Description of Seven New Species of Crustacea and One Worm from Arctic Alaska. Proc. U.S. Nat. Mus., Vol. VII, p. 518.

1885. Report of the International Polar Expedition to Point Barrow, Alaska., Part 4, Natural History, p. 89. Washington.

1893. Newcombe, C. F. Catalogue of the Crustacea in the Provincial Museum, Victoria. Bull. Nat. Hist. Soc. Brit. Col.

1849. Nicolet, H. Crustacea in Gay's Historia fisica y politica de Chile; Zoologia, Tome III, c. 4 tav. in fol. Paris.

1897. Nobili, Giuseppe. Decapodi e Stomatopodi raccolti dal Dr. Enrico Festa nel Darien, a Curaçâo, La Guayra, Porto Cabello, Colon, Panama, ecc. Boll. Mus. Zool. Anat. Comp. d. R. Univ. di T'orino, Vol. XII.

1863. Ordway, A. Monograph of the Genus Callinectes. Journ. Bost. Soc. Nat. Hist., Vol. VII, 567.

1890-94. Ortuann, A. Die Decapoden-Krebse des Strassburger Museums. Zoologische Jahrbücheb, Abth. für. Syst., etc., Bd. V, pp. 437 and 693 ; Bd. VI, pp. 1, 241 and 532; Bd. VII, pp. 23, 411 and 683.

1894. The Pelagic Schizopoda. Bull. Mus. Comp. Zool. Harvard College, Vol. XXV, No. 8, p. 99.

1894. A Study of the Systematic and Geographical Distribution of the Decapod Family Atyidro Kingsley. Proc. Acad. Nat. Sci. Phila., p. 397.

1895. A Study of the Systematic and Geographic Distribution of the Decapod Family Crangonidr Bate. Ibid., p. 173.

1896. -Die geographische Verbreitung der Decapodengruppe der Hippidea. Zool. Jahrb. Abth. f. Syst., Bd. IX, p. 219.

1896. Das System der Decapodenkrebse. Ibicl., p. 409.

1897. Die geographische Verbreitung der Decapoden-Familie Trapeziidr. Ibid., Bd. X, p. 201. 
1897. -_ Carcinologische Studien. Ibid., Bd. X, p. 307.

1839. Owex, R. Crustacea in the "Zoology of Beechy's Voyage."

1SS1. Pfeffer, G. Die Panzerkrebse des Hamburger Museums. Verh. Naturw. Vereins Hamburg-Altona (2), Bd. V, p. 22.

1892. Rathbun, Mary J. Catalogue of the Crabs of the Family Periceridr in the U. S. Nat. Mus. Proc. U. S. Nat. Mus., Vol. XV, p. 231.

1893. Catalogue of the Crabs of the Family Maiidæ in the U.S. National Museum. Ibid., Vol. XVI, p. 63.

1893. - Descriptions of New Genera and Species of Crabs from the West Coast of North America and the Sandwich Islands. Ibid., Vol. XVI, p. 223.

1893. - Descriptions of New Species of American Fresh-Water Crabs. Ibid., Vol. XVI, p. 649.

1S94. Notes on the Crabs of the Family Inachidæ in the U. S. National Museum. Ibid., Vol. XVII, p. 43.

1895. - The Genus Callinectes. Ibid., Vol. XVIII, p. 349.

1897. - Descriptions de nouvelles espèces de Crabes d'eau douce appartenant aux collections du Muséum d'histoire naturelle de Paris. Bull. d'Mus. hist. nat. Paris, No. 2, p. 58.

1897. - Synopsis of the American Sesarmæ with Description of a New Species. Proc. Biol. Soc. Washington, Vol. XI, p. 89.

1897. - Synopsis of the American Species of Palicus Philippi (=Cymopolia Roux) with Descriptions of Six New Species. Ibid., p. 93 .

1897. - Synopsis of the America Species of Ethusa with Description of a New Species. Ibid., p. 109.

1897. Description of a New Species of Cancer from Lower California, and Additional Note on Sesarma. Ibid., p. 111.

1897. A Revision of the Nomenclature of the Brachyura. Ibid., p. 153.

1898. The Brachyura Collected by the U. S. Fish Commission Steamer Albatross on the Voyage from Norfolk, Virginia, to San Francisco, California, 1887-1888. Ibid., Vol. XXI, p. 567.

1899. - Notes on the Crustacea of the Tres Marias Islands, from North American Fauna, No. 14, p. 73, U. S. Dept. of Agriculture, April 29.

1899. List of the Crustacea known to occur on or near the Pribilof Islands. The Fur Seals and Fur-Seal Islands of the North Pacific Ocean, Part III, p. 555. Washington.

1900. Symopses of North American Invertebrates. VII, The Cyclometopous or Cancroid Crabs of North America. Amer. Nat., Vol. XXXIV, p. 131. 
1884. Rathbon, RichaRd. Natural History of Economic Crustaceans of the United States. The Fisheries of the United States, Section I, History of Aquatic Animals: Published by the U. S. Fish Commission.

1839. Randali, J. W. Catalogue of the Crustacea brought by Thos. Nuttall and J. K. Townsend from the West Coast of North America and the Sandwich Islands and Descriptions of such Species as are apparently New, etc. Journ. Am. Acad. Nat. Sci., Vol. VIII, p. 106.

1884. Richters, F. Beitrag zur Kentniss der Krustaceen-Fauna des Behringsmeeres. Abhandl. senckenberg. Nat. Gesell., Bd. XIII, p. 401 .

1885. Sars, G. O. Report on the Schizopoda. Challenger Reports, Vol. XIII.

1853. Sadssure, H. De. Description de quelques Crustacés nouveux de la côte occidentale du Mexique. Rev. et Mag. de Zool. (2), Tome V, p. 354, Pls. XII and XIII.

1857. Diagnoses de quelques Crustacés nouveaux des Antilles et du Mexique. Ibid. (2), Tome IX, p. 304.

1857. - Diagnoses de quelques Crustacés nouveaux de l'Amérique tropicale. Ibid. (2), Tome IX, p. 501.

1858. - Memoire sur divers Crustacés nouveaux des Antilles et du Mexique. Mem. Soc. Phys. Geneve., Tome XIV, p. 417.

1892. SchalfEew, P. Carcinologische Bemerkungen aus dem Zoologischen Museum der Kaiserlichen Akademie der Wissenschaften. Mélanges biologiques, Tome XIII, p. 325; du Bull. Acad.impériale des sciences de St. Pétersbourg, Tome XXXV, p. 331.

1893. Sharp, B. D. Catalogue of Crustaceans in the Museum of the Academy of Natural Sciences of Philadelphia. Proc. Acad. Nat. Sci. Phila., p. 104.

1869. Smith, Sydney I. Descriptions of a New Genus and Two New Species of Scyllaridø and a New Species of Aethra from North America. Am. Journ. Sci. Vol. XLVIII, p. 118; also in Ann. Nat. Hist. (4), Vol. IV, p. 228.

1869. - - Notes on New or Little Known Species of American Cancroid

Crustacea. Proc. Bost. Soc. Nat. Hist., Vol. XII, p. 274.

1869. - Notes to Verril. American Naturalist, Vol. III, p. 245.

1869-70. List of Crustacea Collected by J. A. McNiel in Central America. Rep. Peabody Acad., 1869-70, p. S7.

1871-73. - Notes on American Crustacea, 1.-Ocypodoidea. Trans. Conn. Acad. Sci. (1869), Vol. II, p. 113, with 4 Pls.

1878-79. - Notes on Crustacea Collected by Dr. G. M. Dawson at Vancouver's and the Queen Charlotte Islands. Rep. Prog. Geol. Sur. Canada, 1878-79, B, p. 206. 
1893. Stebbing, T. R. R. A History of Crustacea. International Scientific Series. New York.

1S56. Strmpsox, Wm. On Some California Crustacea. Proc. Cal. Acarl. Sci., Vol. I, p. 87.

1857. Notices of New Species of Crustacea of Western North America. Proc. Bost. Soc. Nat. Hist., Vol. VI, p. 84.

1857. On the Crustacea and Echinodermata of the Pacific Shores of North America. Journ. Bost. Soc. Nat. Hist., Vol. VI, p. 444.

185s, '60. - Prodromus descriptionis animalinm evertebratorum, quæ in Expeditione ad Oceanum Pacificum Septentrionalem, a Republica Federata missa, *** observavit et descripsit W. Stimpson. Proc. Acad. Nat. Sci. Phila., 1858, pp. 31, 93, 159, 225; and 1860, p. 22.

1860. - Sketch of a Revision of the Genera of Mithracidø. Am. Journ. Sci. (2), Vol. XXIX, p. 132.

1860. - - Notes on North American Crustacea. Ann. N. Y. Lyc. Nat. Hist., Vol. VII, pp. 49 and 176.

1864. Descriptions of New Species of Marine Invertebrata from Puget Sound. Proc. Acad. Nat. Sci. Phila., 1864, p. 153.

1866. Descriptions of New Genera and Species of Macrourous Crustacen from the Coasts of North America. Proc. Chicago Acad. Sci., Vol. I, p. 46.

1871. - Notes on North American Crustacea. Ann. N. Y. Lyc. Nat. Hist., Vol. X, p. 92.

1893. - Extract from an Unpublished Report of Dr. William Stimpson, on the Crustacea of the North Pacific Exploring Expedition, 1853 to 1856. Proc. U.S. Nat. Mus., Vol. XVI, p. 95. Appended to Miss Rathbun's paper, No. 2.

1870. Streets, T.H. Notice of Some Crustacen of the Genus Libinia, with Descriptions of Four New Species. Proc. Acad. Nat. Sci. Phila., 1870, p. 104.

1871. - Descriptions of Five New Species of Crustacea from Mexico. Ibid., p. 225.

1871. Catalogue of Crustacea from the Isthmus of Panama. Ibid., p. 238.

1877. Contributions to the Natural History of the Hawaiian and Fanning Islands and Lower California (Crustacea). Bull. U. S. Nat. Mus., No. 7, p. 103.

1877. Streets, T. H. ANd Kingslex, J. S. An Examination of Types of Some Recently Described Crustacea. Bull. Essex Inst., Vol. IX, p. 103.

1882. Stuxberg, Anton. Evertebratfaunen i Siberiens Ishav. VegaExpeditionens Vetenskapliga Iakttagelser, Bd. I, p. 677. 
1815. Tilesius, W. G. De Cancris Camtschaticis, Oniscis, Entomostracis, et Cancellis marinis microscopicis noctilucentibus, cum appendice de Acaris et Ricinis Camtschaticis. Mem. Acad. Sci. St. Petersbourg, Tome V, p. 331.

1886. Underwood, L. M. List of Described Species of Fresh Water Crustacea from America North of Mexico. Bull. Illinois State Lab. Nat. Hist., Vol. II, p. 323.

1898. Walker, A. O. Crustacea Collected by W. A. Herdman, F. R. S., in Puget Sound, Pacific Coast of North America, September, 1897. Trans. Liverpool Biol. Soc., Vol. XII, p. 268.

1898. Malacostraca from Puget Sound, N. W. America. Ann. Nat. Hist. (7), Vol. II, p. 275.

1846. White, Adam. On a New Genus of Crustacea. Ann. Nat. Hist., Vol. XVII, p. 497.

1847. L-List of Crustacea in the British Museum. London.

1848. Description of Echinocerus cibarius, a New Species and Subgenus of Crustacea. Proc. Zool. Soc. London, Vol. XVI, p. 47.

1855. On a New Species of Anomourous Crustacean Belonging to the Family Homolidæ Found by Mr. Wm. Lobb, at Monterey in California in the Winter of 1850. Ann. Nat. Hist. (2), Vol. XV, p. 307; also in Proc. Linn. Soc. London, Vol. II, p. 329.

1856. Some Remarks on Crustacea of the Genus Lithodes, with a Brief Description of a Species Apparently Hitherto Unrecorded. Proc. Zool. Soc. London, Vol. XXIV, p. 132.

1878. Whiteaves, J. F. On Some Marine Invertebrata from the West Coast of North America. Canadian Naturalist (2), Vol. VIII, p. 464.

1836. Wiegmann, A. Beschreibung einiger neuen Crustaceen des Berliner Museums aus Mexiko und Brazilien. Archiv. für Naturgeschichte, Bd. II, p. 145. 


\section{INDEX TO GENERA AND SPECIES OF CALIFORNIA STALK-EYED CRUSTACEA.}

Names of new genera and species in heavy faced type; synonyms in italics.

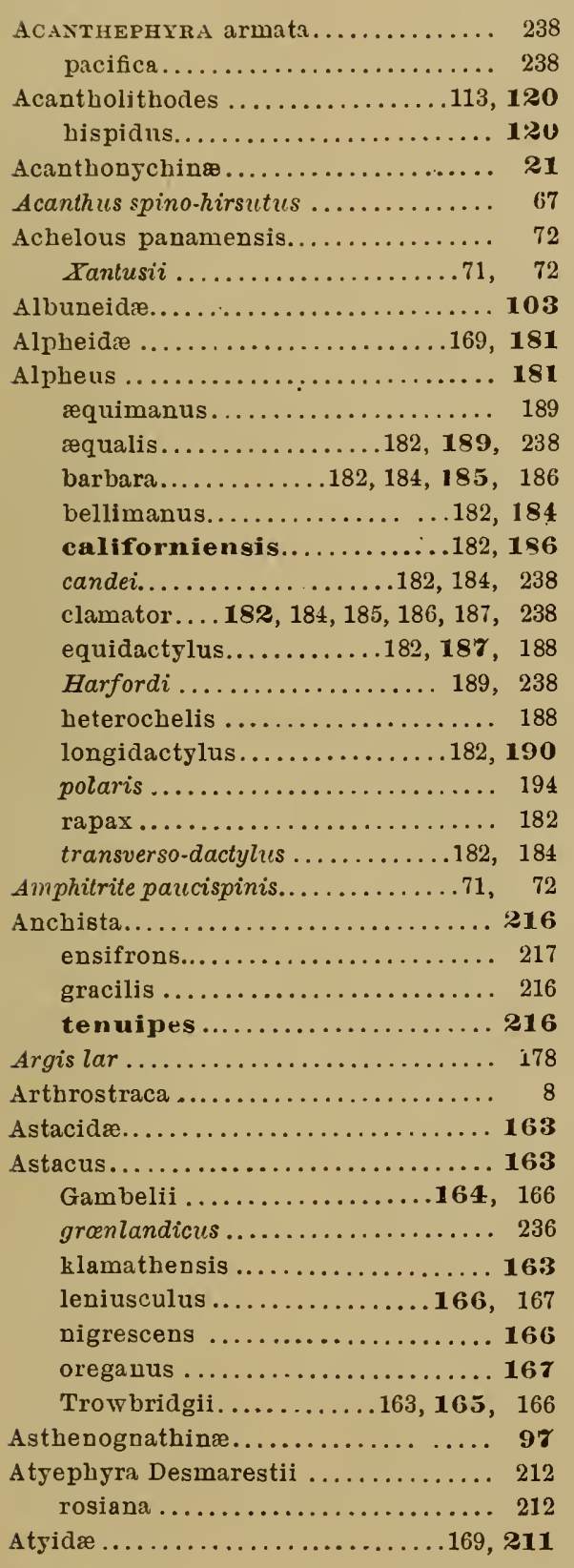

Bernhardus armatus.............. 137

hirsutiusculus.................. 143

tenuimanus................. 148

Betous cequalis................... 189

equimanus.................... 189

Harfordi..................189, 238

longidactylus ................ 190

Blepharipoda................... 103 occidentalis...............103, 104

Brachynotus ................ 89,81 uudus..................81, 83 oregonensis .............8 83 sexdentatus ................ 81 Brachyura ...............10, 12, 14, 15

Calappide.................... 98

Callianassa .................... 159 affinis.................... 162 californiensis .........159, 161, 238 gigas................162, 238 longimana..............161, 238 occidentalis................... 159 Callianassidæ................... 15

Callinectes ..................... bellicosus.................. $\mathbf{7 3}$ diacanthus.................... 73

Callomysis .................... 2R4 maculata................... $2 \mathbf{2 4}$

Cambarus Gambelii................ 164 Cancer.................47, 55, 237 amphiœtus................... 55 antennarius.......47, 48, 49, 53, 51 Anthonyi................... 237 boreas ........................ 177 cheiragonus ................... 69 gibbosulus................... 55 gracilis................. homaroides.................. 177 irroratus ..................... 50 Jordani .................... 237 magister...............47, 50, 52 opilio .................... 39 oregonensis........53, 54, 55, 82, 83 perlatus.................... 47 phalangium................... 39 productus.............47, $49, \quad 50$ spinus...................... 235 
Cancrini $. . . \ldots \ldots \ldots \ldots \ldots \ldots \ldots \ldots, \mathbf{4} \boldsymbol{7}$

Cancroidea ...................15, 47

Cardita borealis................... 96

Caridea ........................102, 169

Caridina ......................... 214

Desmarestii................... 212

pasadenæ.................214, 238

typus ....................... 214

Catometopa.......................

Cheiragone...................... 68

Cheiragonus cheiragonus............ 69

hippocarcinoides............... 69

Cheraphilus boreas................. 177

Chionœcetes ...................31, 39

behringianus.................. 39

opilio .....................39, 40

Tanneri...................... 40

Chorilia longipes.................. 33

Clibanarius turgidus............... 151

Clymenella..................... 92

Crangon...........................170

affinis..................... 171

alaskensis.................170, 171

alba........................ 174

boreas ...................177, 238

crangon.................170, 171

crangon affinis .............170, 173

franciscorum..........17 $2,174,238$

lar........................ 178

munitellus .............176, 238

munitus.............175, 176, 238

nigricauda..................

$170,171,172,173,174,175$

nigromaculata............. 173

stylixostris................ 174

vulgaris ...................170, 173

vulgaris var. affinis. ........... 170

Crangonidæ..................169, 170

Crangoninea..................... 169

Cryptolithodes.................113, 123

alla-fissura ..................... 125

brevifrons .................. 127

sitchensis.................124, 1\%5

typicus ..............124, 126, 127

Cryptophrys.................... 96

concharum ................... 96

pubescens.................... 96

Cryplopodia occidentalis............. 44

Ctenorhinus setimanus.............. 128

Cumacea........................ 8

Cyclometopa.................... 47

Cycloxanthops.................... 56

novem-dentatus ..........56, 59

rugosa ................... 59 sexdecimdentatus............... 56

vittatus.................... 58

Cycloxanthus californiensis.........56, 58 novem-dentatus...........56, 58, 59 vittatus $\ldots \ldots \ldots \ldots \ldots \ldots \ldots \ldots \ldots, \quad 58$

Cynthia......................... 87

DASYGXINE.....................

Dasygyius.....................

tuberculatus ............. 28

Decapoda...................... 8

Dermaturus...................113, 116

Gilli....................... 118

hispidus..................... 120

inermis....................... 119

Mandtii...................... 116

Echinocerus cibarius................ 128

foraminatus ................. 130

setimanus .................... 128

Elassocheirus................... 135

Enoplometopus occidentalis........ 167 pictus ..................... 167

Entomostraca................... 7

Ephyra compressa................. 212

Epialtus ...................... $\quad \mathbf{2 1}$

bituberculatus............... 21

(Antilibinia) Nuttallii........... $\mathbf{2 3}$

productus..................22, 23

Erileptus...................... 20

spinosus.................... 21

Eucrale californiensis.............. 77

Eupagurus...................132, 134

alaskensis.................... 135

aleuticus .................. 136

armatus..................... 137

Bernhardus.........132, 133, 134, 136

Brandti..................... 139

californiensis .. ............... 149

capillatus...................... 138

confragosus................... 141

Dalli........................ 139

Gilli...................... 135

granosimanus .................. 146

Hemphillii................... 147

hirsutiusculus................. 143

Kennerlyi................. 143

Kröyeri................133, 139

Mertensii ................... 155

Middendorffii................ 234

munitus....................... 150

Newcombei .................... 142

ochotensis...................... 137

Rathbuni................... 140

Samuelis..............144, 145, 147 
splendescens .................... 234

Tanneri...................... 140

tenuimanus.................. 148

trigonocheirus ............... 138

turgidus..................... 151

Euphausiidæ...................228

FABIA.................... 8 subquadrata................... 8

Fisheria depressa ..............37, 38

Galathea gregaria.................. 111

Galatheidea.....................102, 106

Galatheinea...................... 110

Gebia californica................. 157 pugettensis.................. 157

Gecarcinidæ..................... $\mathbf{7 4}$

Gelasimus annulipes ................ 76

crenulatus................... 75

gracilis...................... 75

rectilatus..................... 76

vocator ...................... 75

Gonodactylus styliferus.............. 220

Grapsidæ.....................74, 78

Grapsodius ................. 79,83 eximius.................... 84

Grapsoidea...................16, 74

Guiaia ornata.................... 100

HaLiotis rufescens.............. 190

Hapalogaster ..................... 113

Brandti......................... 118

cavicauda...............113, 115

Grebnitzkii .................... 115

inermis .................... 119

Mandtii....................... 116

Mertensii ..................113, 115

Haplopodinea .................. 169

Hectarthropidæ................... 169

Heptacarpus .............192, 194, 195

brevirostris...........198, 200, 238

carinatus ................ 202

cristatus.................... 202

gracilis.....................205

Herdmani ...............204, 238

palpator .......196, 198, 199, 202, 238

paludicola.................201

pictus..................200, 201

stylus .................... 204

Suckleyi.................... 205

Taylori ...............199, 200, 202

tenuissimus . ..............203

Herbstia.................31, 36, 37

(Herbstiella) camptacantha...... 37 parvifrons................ 37, 38
Herbstiella..................... 37

camptacantha................. 37

Hermit crabs.................... 132

Heterocrypta................... 44

occidentalis .................. 44

Heterograpsus nudus................ 81

oregonensis (see errata) ......... 82

sanguineus................... 81

Heteromysis.................... 224

formosa.................... 225

odontops .................... 225

spinosus .................. 225

Hippa ...................... 102

analoga ..................... 103

emerita...................102, 103

talpoidea.................... 103

Hippidæ. ..................... 102

Hippidea .................... 102

Hippolysmata.................. 180 californica ...............180, 238 vittata..................... 180

Hippolyte..................192, 194 affinis..................194, 238

armata...................... 195

brevirostris.................. 198 californiensis .............193, 238 cornuta...................... 195 cristata...................... 202 esquimaltiana.................. 195 Gaimardii................194, 238 gracilis........................ 205 grœnlandica...............194, 236 Hemphillii..................... 196 lamellicornis................... 208 Layi ................... 193, 238 lineata..................180, 181 ochotensis................... 195 palpator..................196, 198 Phippsii .................195, 238 picta....................195, 200 polaris....................... 238 prionata...................... 206 sitchensis................... 195 spinus .....................195, 235 stylus...................... 204

Suckleyi...................... 205

Taylori........................ 199

turgida ..................... 195

varians ...................... 192

vibrans....................... 195

Hippolytidæ ..................169, 192

Holopagurus ................. 153 pilosus..................153, 154

Homaridea .................102, 163 


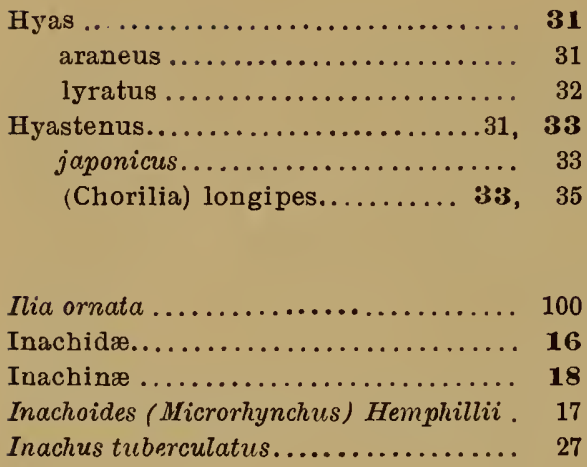

KeLP Crab...................... 22

LABIDOCHEIRUS.................. 135

Lambrus frons-acutis............44, 45

Leiolambrus................... 4.5 punctatissimus ............... 46

Lepidopa ...................... 105 myops................... 105

scutellata................... 105

Lepidops see Lepidopa.............. 105

Lepidops myops................... 105 Leptopodiinæ................... 1 7

Leptostraca..................... 8

Leucosiidæ...................... 99

Lencosoidea...................... 98

Libinia ........................ 4

affinis .......................... 43

canalaculata.................43, 44

emarginata................ $\mathbf{4 3}$

Liosoma arenata.. ............... 93

Lithodes .....................113, 131

æquispinus.................. 132

brevipes................... 132

californiensis................ 131

camtschaticus ................ 132

Couesi . ..................... 132

panamensis................. 132

Rathbuni ................... 131

Lithodinea......................113

Lopholithodes . ...............113, 12' foraminatus ................. 130

Mandtii.................128, 130

Lophopanopeus ................ 236 bellus....................... 60

diegensis .................. 237

frontalis................64, 236, 237

Heathii..................... 237

leucomanus.................. 61

Lockingtoni ................. 237
Lophoxanthus ................. 59 bellus.........60, 61, 62, 63, 64236 var. leucomanus........... 63 frontalis $\ldots \ldots \ldots \ldots \ldots \ldots \ldots \ldots 61,64$ lamellipes .................. 59 leucomanus.........61, 63, 64, 236 Lophozozymus (Lophoxanthus) bellus... 60 var. leucomanus............. 63

frontalis .................... 64

Loricata....................102, 168

Loxorhynchus ................... $\mathbf{2 9}$

crispatus.................... 30 grandis.................. 30

Lucapina crenulata................ 97

Lupa bellicosa................. 73

MaCroura ................9, 12, 14, 101

Maiidæ ........................ $\$ 1$

Maiinæ....................... $\mathbf{3 1}$

Maiinea ........................ 16

Maioidea..................... 16

Malacostraca ................... 8

Metacarcinus magister............. 50

Micropanope latimana............. 67

Microphrys tumidus............... $\quad 35$

Microrhynchus ................... 27

Hemphillii................... 17

(Inachus) tuberculatus ........... 27

Miersia pacifica................... 213

pelagica...................... 213

Mimulus....................... 23

foliatus................... 23

Monocarpinea.................... 169

Munida........................ 111

(Grimothea) gregaria........... 111

rugosa....................... 111

subrugosa $\ldots \ldots \ldots \ldots \ldots \ldots \ldots \ldots, 111$

Mya arenaria................... 96

Mysidæ ........................ 221

Mysidopsis ...................226

didelphys................... 226

elongata.................... 226

Mysis...................... 221

costata.................. 221

octulata..................... 221

Nebalia $\ldots \ldots \ldots \ldots \ldots \ldots \ldots \ldots, 7, \quad 8$

INectocrangon..................... 18

alaskensis .................. 189

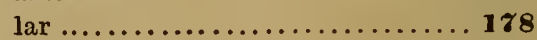

Neomysis..................... $2 \boldsymbol{Z} \mathbf{Z}$

franciscorum............. 223

mercedis................... $22 \mathbb{2}$

Rayii ..................... 223

vulgaris .................. 222 
Neorhynchus.. ................ 27 mexicanus ................27, 28

Nephrops occidentalis ........... 167

Neptunus asper................. 71 Xantusii.................. 71

Nikidre..................169, 179

OcrPodID.................... $\boldsymbol{\gamma}_{\mathbf{4}}$

Edignathus ............... 113, 117 Brandti.............117, 118, 119 Gilli.................. 118 inermis ..... ............ 119

Opisthopus .................. 97 transversus . .............. 97

Oregonia....................... 19 gracilis.................19, 20 hirta................... 20 longimana.................19, 20

Oxyrbyncha.................. 16;

Oxystomata $\ldots \ldots \ldots \ldots \ldots \ldots \ldots \ldots 16,98$

P.CH YCHELES ................. 108

grossimanus................. 109

pubescens ................ 110

rudis..................109, 110

setimanus ................. 110

Pachydesma classitelloides.......... 88

Pachygrapsus ...............79, 85 crassipes ............... 81 parallelus................... 80

Paguridæ ..................132

Paguridea..................102, 112

Pagurinea..................132

Paguristes..................... 151

Bukeri ................... 152

fecundus .................. 153

longirostris................ 151

parvus.................... 151

turgidus .................... 151

Pagurus ............132, 131, 135, 155 alaskensis.........133, 134, 135, 135 aleuticus .............133, 134, 136 Bernhardus..........132, 133, 134, 136 Brandti . .................134, 139 californiensis .............135, 149 capillatus ...............134, 138 confragosus..............134, 141 Dalli ....................134, 139 Gilli...................... 135 granosimanus .............134, 146 Hemphillii ...............134, 147 hirsutiusculus.........134, 143, 144 Kennerlyi ...............134, 143 Kröyeri ..................133, 139 Mertensii.................. 155 Middendorffii

234 minimus................134, 145 munitus.............135, 148, 150 Newcombei..............134, 14\% ochotensis ...............134, 137 pubescens.................... 139 Rathbuni ..............134, 140 Samuelis................134, 144 splendescens .............135, 234 Tanneri ............. 134, 140, 141 tenuimanus..............135, 148 trigonocheirus ......134, 138, 139, 140

Palæmon.....................215 Ritteri.................216, 238

Palæmonidæ.................169, 215

Palinurus ....................... 168 interruptus ................ 168

Pandalidæ................... 169, 208

Pandalus........................ 209

annulicornis ................. 209

borealis................... 210

Danæ.................209, 238

franciscorum...............211

Gurneyi...................210

pubescentulus............210, 238

Panulirus................... 168 gracilis.................. 169

iuterruptus............... 168

Paracrangon ................. 176 echinatus.............176, 238

Paralithodes californiensis.......... 131

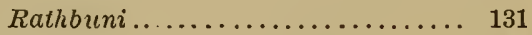

Parapaguridæ................. 155

Parapagurus.................. 155

Mertensii................. 15.5

pilosimanus................ 155

Parapinnixa.................. 95 affinis.................... 95

nitida..................... 95

Paratja...................... 212

Parthenope punctatissima.......... 46

Parthenopidæ.................. 4

Parthenopinea................. 44

Pelia.......................31, 35 mutica................... 36 pacifica ................. $\mathbf{3 6}$ pulchella................... 35 tumida.................. 35

Penæidæ.....................

Penæidea . ................102, 217

Penæus .....................217

braziliensis. ................. 219

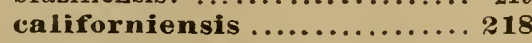

canaliculatus ..............218, 219

Periceridre.................. 42

Pericerinæ.................. 43 


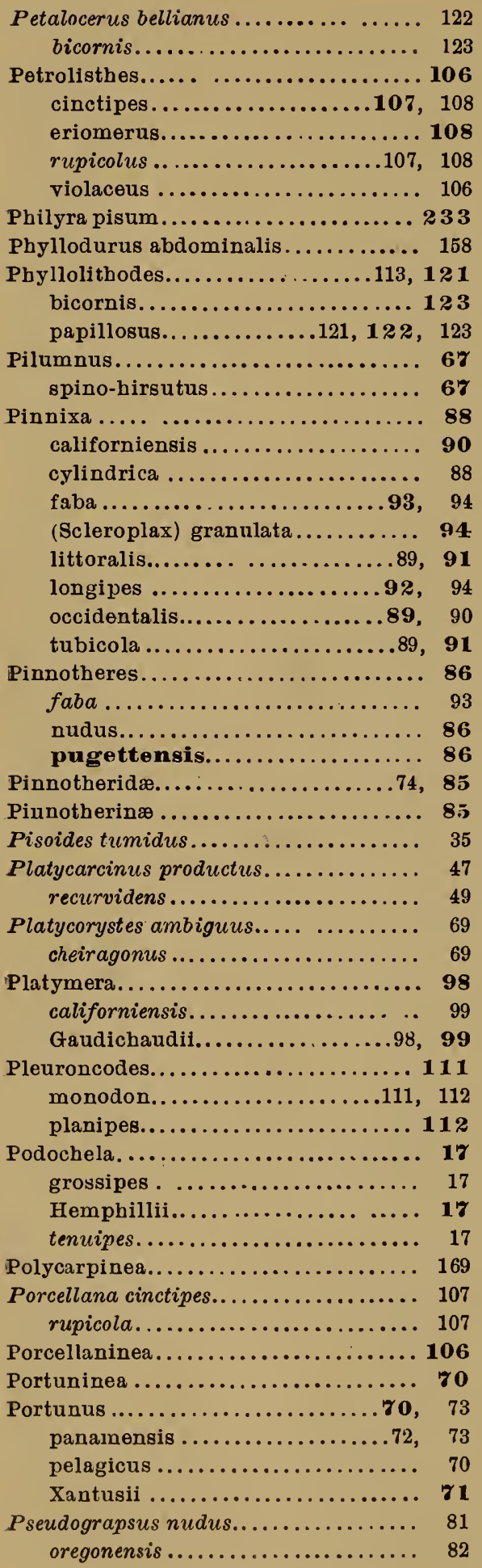

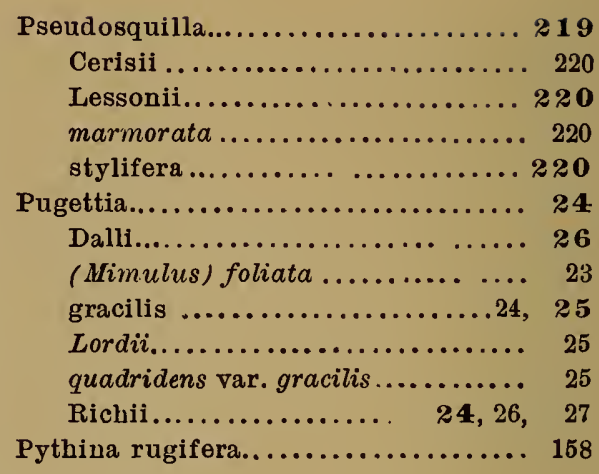




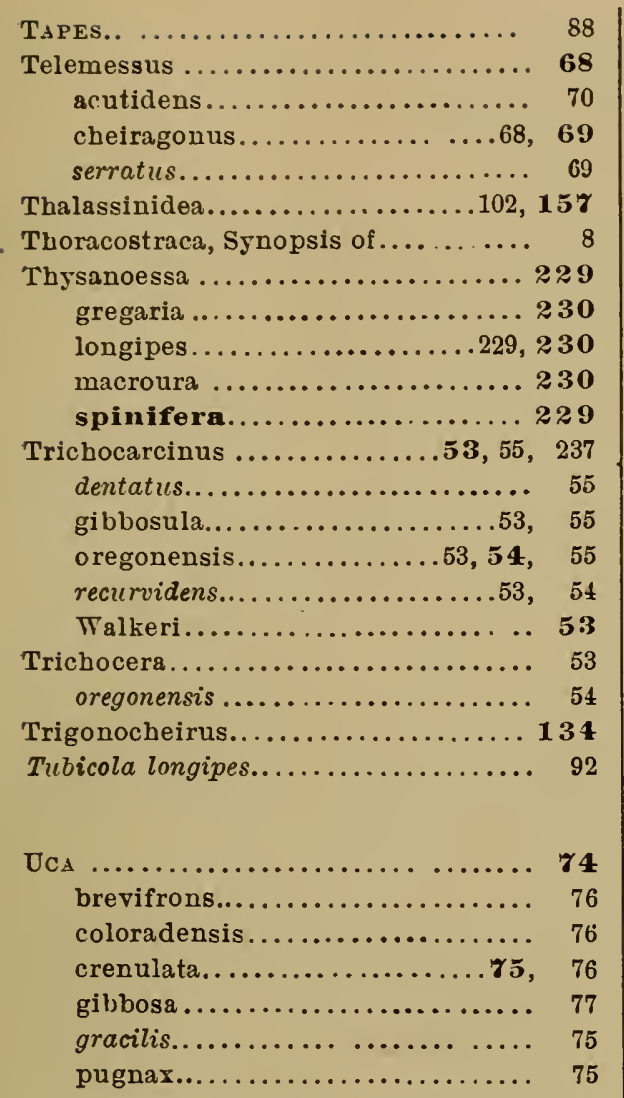

rectilata................... $\gamma_{6}$

speciosa................... 77

stemodactyla................. 77

vocator..................... 75

Upogebia .................... 157

pugettensis.............15 7,238

stellata.................... 157

ХaNthis..................... 65

latimanus.................. 66

Taylori..................... \$55

Xanthini...................55, 68

Appendix to................. 68

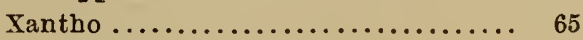

bella ...................... 60

Hemphilliana ................ 60

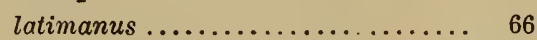

novem.dentatus..............56, 58

spini-tuberculatus .............. 65

vittata.................... 58

Xanthodes........................ 65

Hemphilliana................... 60

Hemphillii.................60, 61

latimanus................... 66

leucomanus .................. 61

novem-dentatus................. 56

Taylori..................... 65

Xiphocaris compressa............. 212

elongata................... 212

Zanthopsis $\ldots \ldots \ldots \ldots \ldots \ldots \ldots \ldots \ldots \ldots \ldots$

\section{ERRATA.}

Page 60, in synonymy, for Xanthodes Hemphilliana read Xantho Hemphilliana.

Page 82, fourth line from bottom should read, "Heterograpsus oregonensis STimpson," etc.

Page 128, fourth line from bottom, for Echinocerus sentimanus read Echidnocerus setimanus.

Page 128, reference to Ctenorhinus setimanus, page 48 in first edition of Proc., page 47 in second edition; reference to Echidnocerus setimanus, page 88 in first edition of Proc., page 96 in second edition.

Page 137, in synonymy, for Eupagurus ochotensis read Pagurus (Eupagurus) ochotensis.

Page 137, in center of page, strike out ( ) around Brandt.

Page 194, second line from bottom, after "Island" insert "and Queen Charlotte Islands." 


\section{EXPLANATION OF PLATE I.}

The figures were drawn by means of a camera lucida.

Fig. 1. Epialtus productus, carapace.

Fig. 2. Cycloxanthops novem-dentatus.

Fig. 3. Lophoxanthus bellus, carapace.

Fig. 4. " " leucomanus, carapace.

Fig. 5. " " frontalis, carapace.

Fig. 6. " " hand.

Fig. 7. Ucc crenulata, carapace.

Fig. 8. " " " onter maxilliped.

Fig. 9. " " "

Fig. 10. " rectilata, carapace.

Fig. 11. " " " inner side of large hand.

Fig. 12. " " " maxilliped.

Fig. 13. " " " merus of large cheliped.

Fig. 14. " " carpus and hand of smail cheliped.

Fig. 15. Petrolisthes eriomerus, cheliped.

Fig. 16. Dermaturus Mandtii, acicle.

Fig. 17. Edignathus Brandtii, acicle.

Fig. 18. " " " outer maxilliped.

Fig. 19. " " " " squamæ of the carapace (enlarged).

Fig. 20. " " " outline of the carapace. 
Oc.Papers, Cal.Acad. Sei.Vol.Vil.

[Holmes] Plate I.
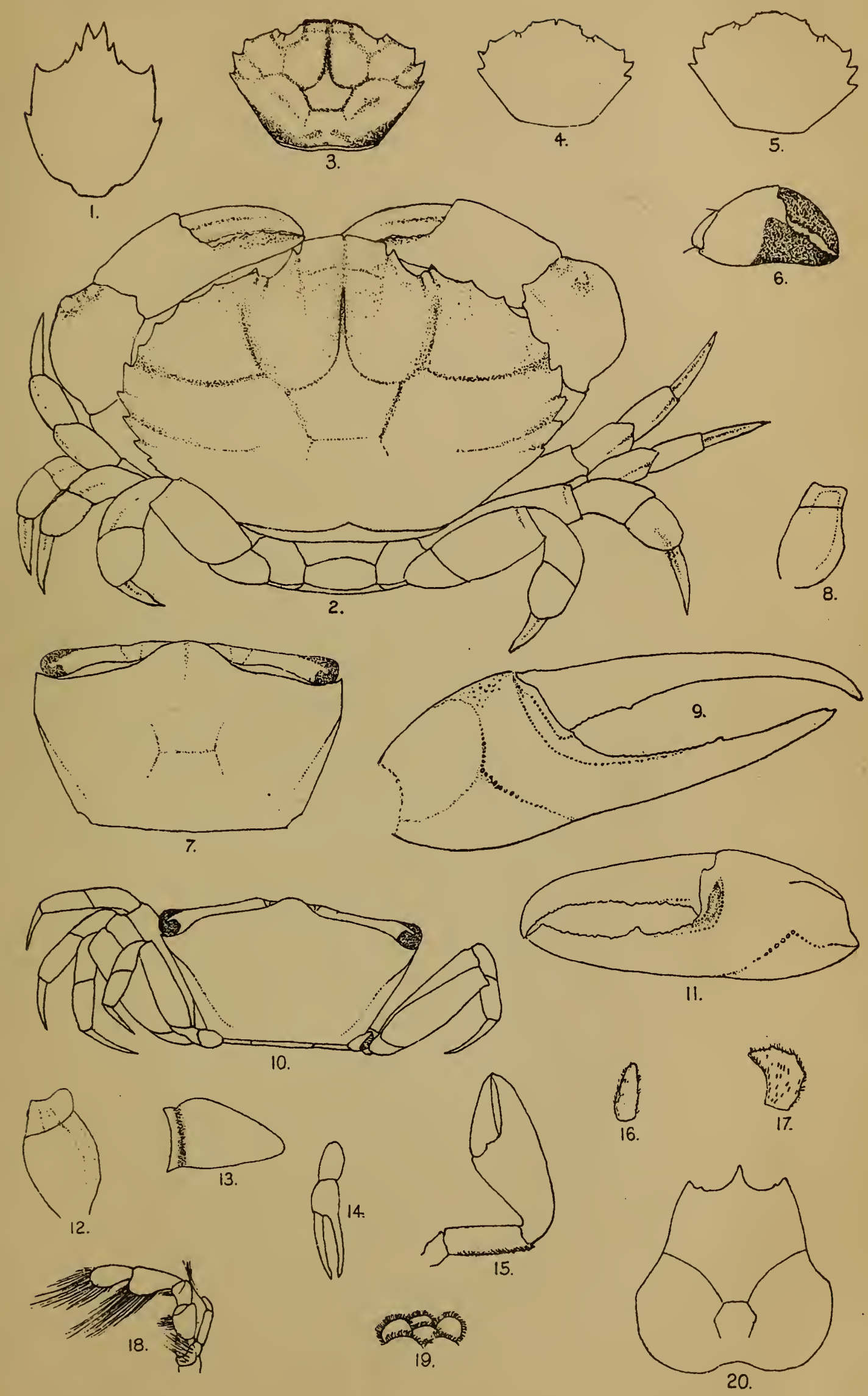




\section{EXPLANATION OF PLATE II.}

Fig. 21. Cryptolithodes sitchensis, carapace.

$\begin{array}{llll}\text { Fig. 22. } & \text { " } & \text { " } & \text { large hand. } \\ \text { Fig. 23. } & \text { " } & \text { " } & \text { small hand. } \\ \text { Fig. 24. } & \text { " } & \text { " } & \text { last two joints of ambulatory leg. } \\ \text { Fig. 25. } & \text { " } & \text { " } & \text { abdomen of a female. }\end{array}$

Fig. 26. Paguristes parvus, eyes and anterior portion of the carapace.

Fig. 27. Callianassa californiensis, large cheliped of a male.

Fig. 28. " " longimana, large cheliped of a male.

Fig. 29. " a affinis, large cheliped of a male.

Fig. 30. " " small " same specimen.

Fig. 31. Crangon nigricauda, acicle.

Fig. 32. " nigromaculata, acicle.

Fig. 33. " stylirostris, anterior portion of the carapace.

Fig. 34. " " " " hand.

Fig. 35. " " " acicle.

Fig. 36. Paracrangon echinatus, carapace (after Dana).

Fig. 37. " " hand " "

Fig. 38. Hippolysmata californica, carapace.

Fig. 39. Alpheus clamator, large hand.

Fig. 40. " " small hand.

Fig. 41. " "bellimanus, large hand.

Fig. 42. " californiensis, anterior part of carapace. 


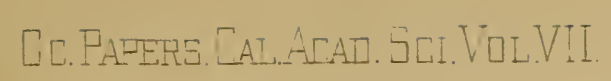

[Holmes] Plate II

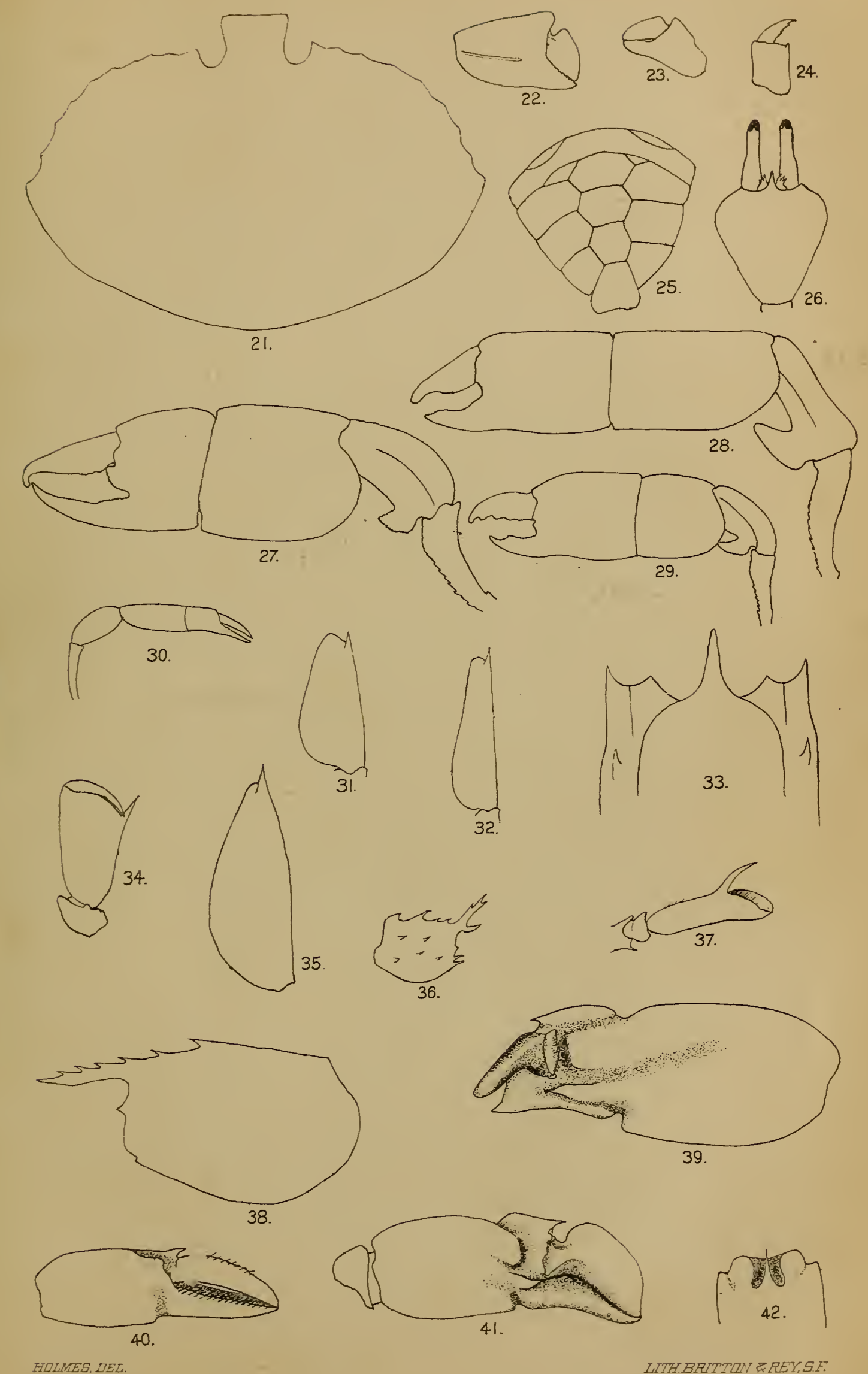

FIOLMES, DEL. 




\section{EXPLANATION OF PLATE III.}

Fig. 43. Alpheus californiensis, large hand.

Fig. 44. " " small hand.

Fig. 45. " " equidactylus, large hand.

Fig. 46. " " " small hand.

Fig. 47. " cequalis, hand.

Fig. 48. Heptacarpus palpator, carapace.

Fig. 49.

Fig. 50.

Fig. 51 .

" " acicle.

Fig. 52 .

" brevirostris, carapace.

Fig. 53.

" "6 acicle.

Fig. 54 .

Fig. 55.

Fig. 56.

Fig. 57.

Fig. 58.

Fig. 59 .

Fig. 60 .

" \ Taylori, carapace.

" " " acicle.

" pictus, carapace.

" " acicle.

" paludicola, carapace.

" " acicle.

" cristatus, carapace.

" " first ambulatory leg.

" carinatus. 
Qu. Papers, Cal. Arad. Sti. Vul.Vii.

[Holmes] Plate III.
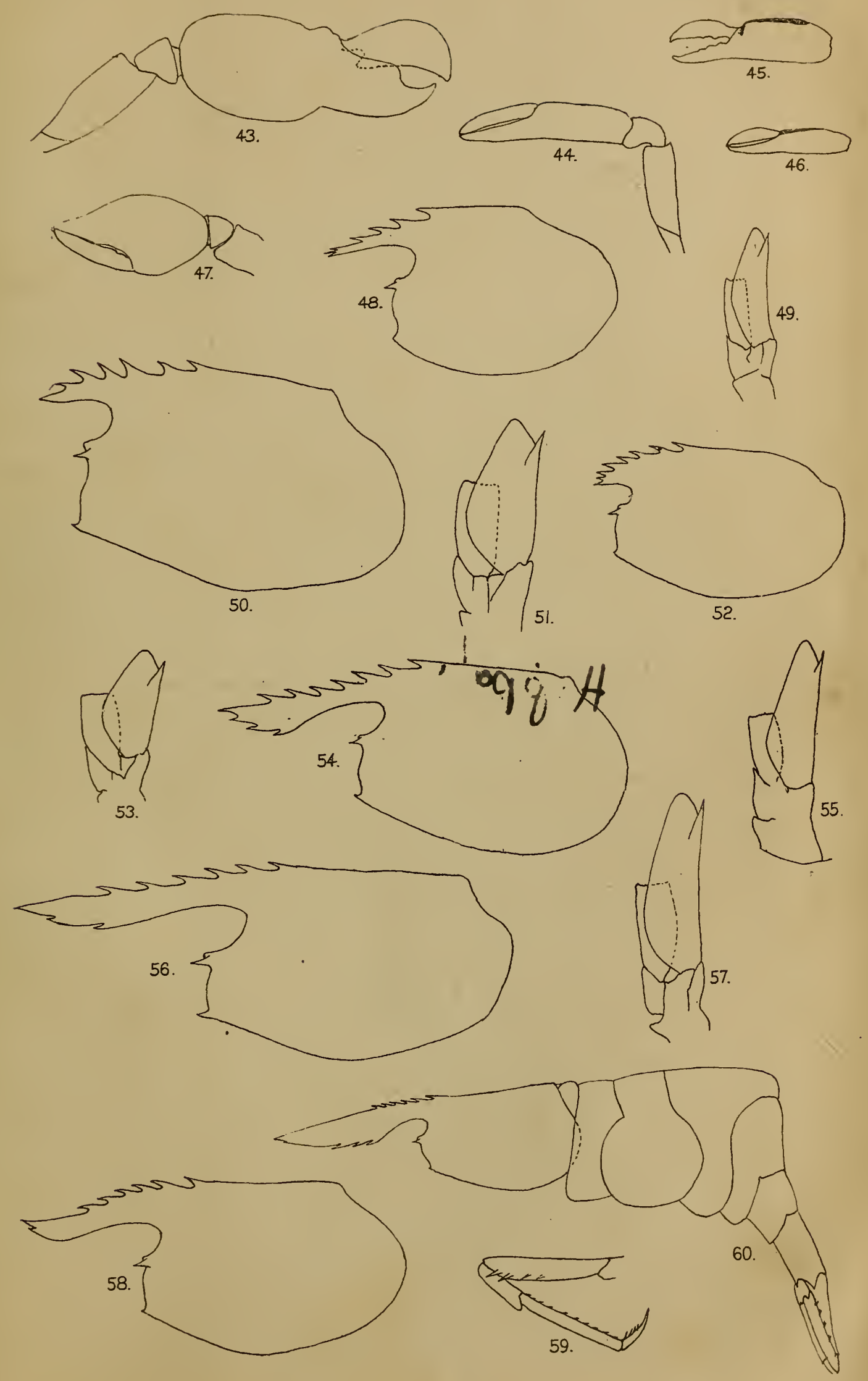




\section{EXPLANATION OF PLATE IV.}

Fig. 61. Pandalus Dance, carapace.

Fig. 62. “ “ acicle.

Fig. 63. Syncaris T'rewi, carapace.

Fig. 64. Pencus californiensis, carapace.

Fig. 65. " " " hand and carpus of first pereopods.

Fig. 66. " " " " 6 hand and carpus of second pereopods

Fig. 67. " " "

Fig. 68. " " " " abdomen.

Fig. 69. " " " acicle.

Fig. 70. Mysis costata, telson and outline of uropods.

Fig. 71. " " " antenna.

Fig. 72. " " " fourth pleopod of a male.

Fig. 73. Heteromysis spinosus, antenna.

Fig. 74. " " " third maxilliped.

Fig. 75 . " " "

Fig. $76 . \quad$ " " “ telson and outline of uropods.

Fig. 77. Mysidopsis elongata, antennule of the male.

Fig. 78. " " " antennule of the female.

Fig. 79. " " " " antenna.

Fig. 80. " " " telson and uropods.

Fig. 81. Thysannessa spinifera. 
Qc.Papers, CAL Acate

[Holmes] Piate IV.

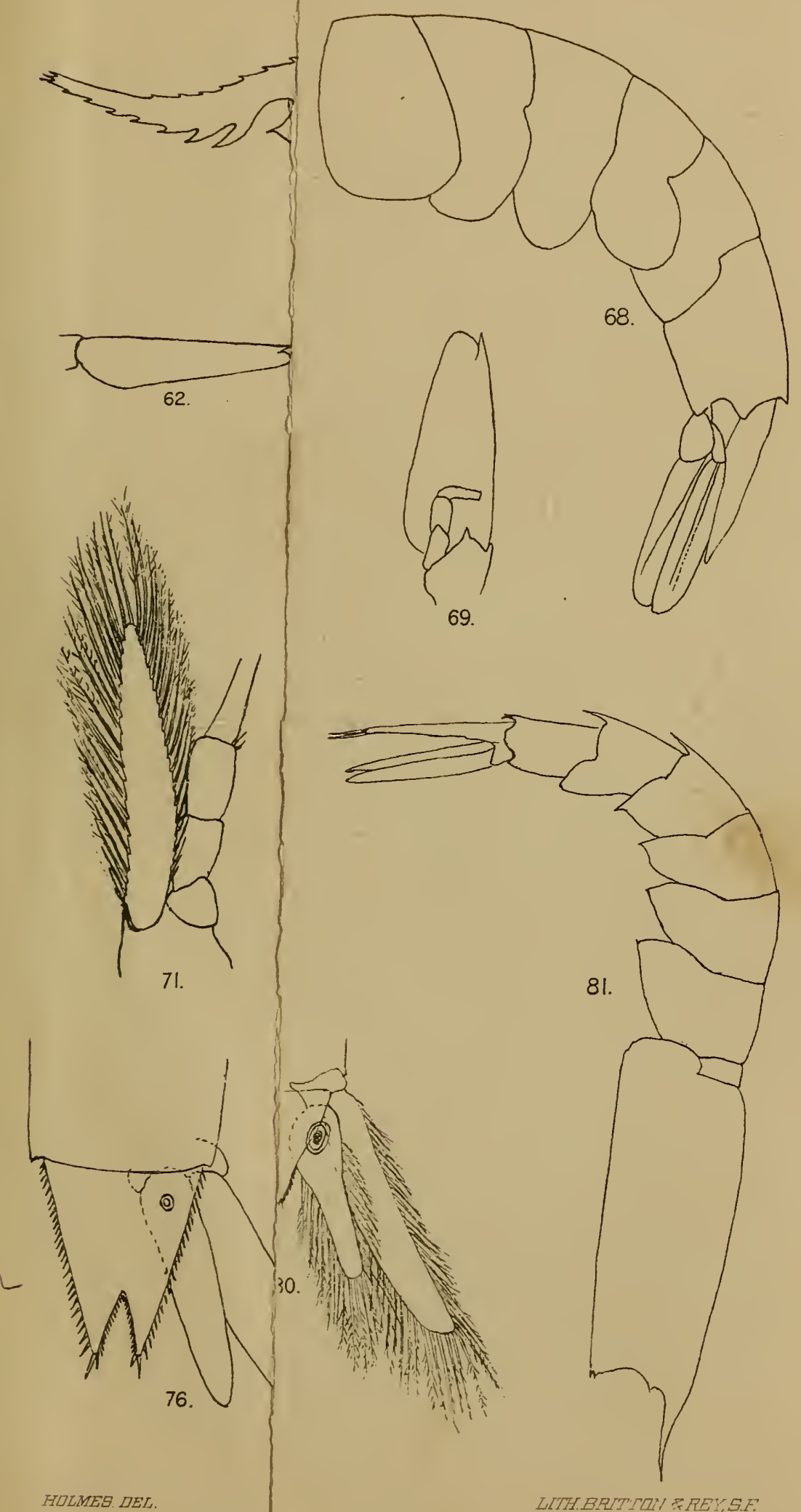

HOLMES DEL. 
Dc. Papers, _at.Acad. Sei.Vul.ViI.
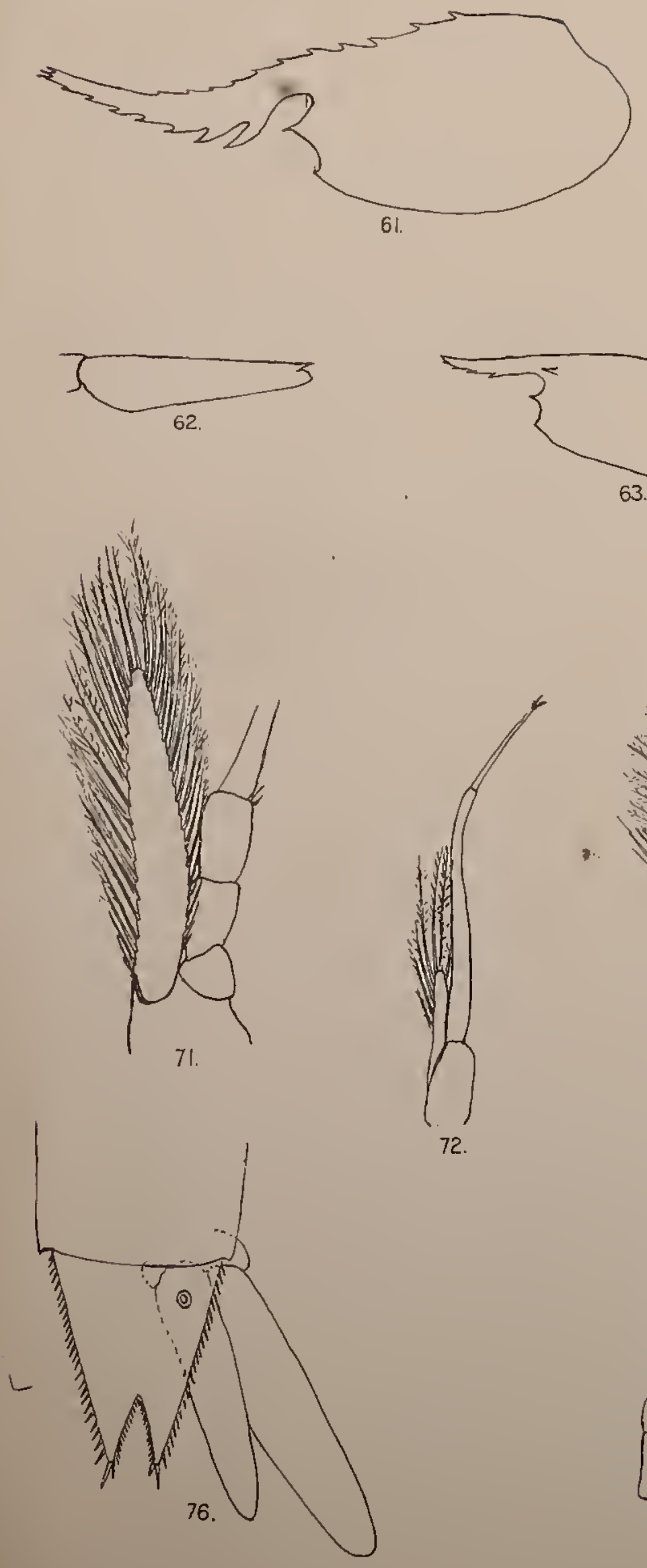
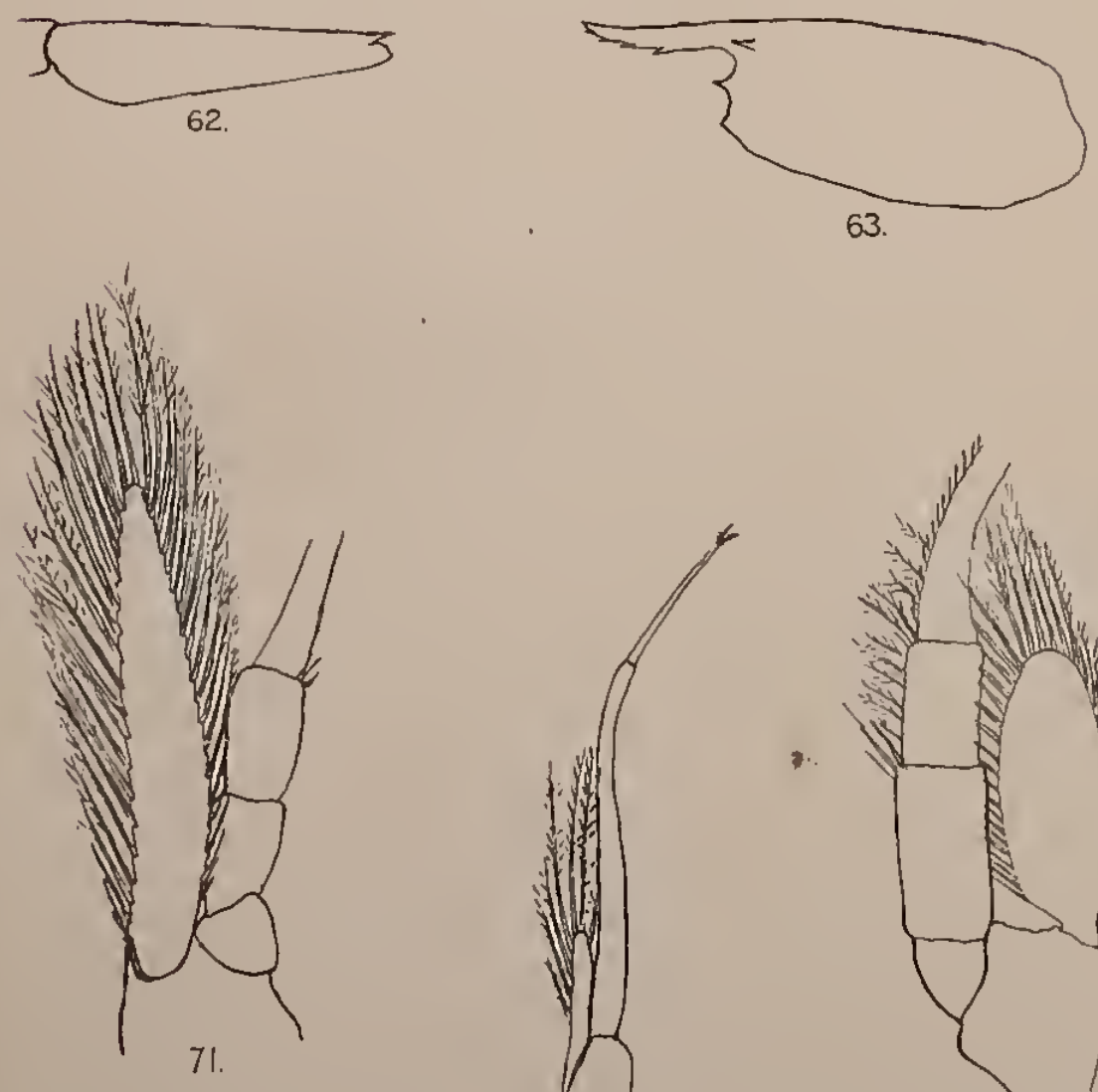

63.
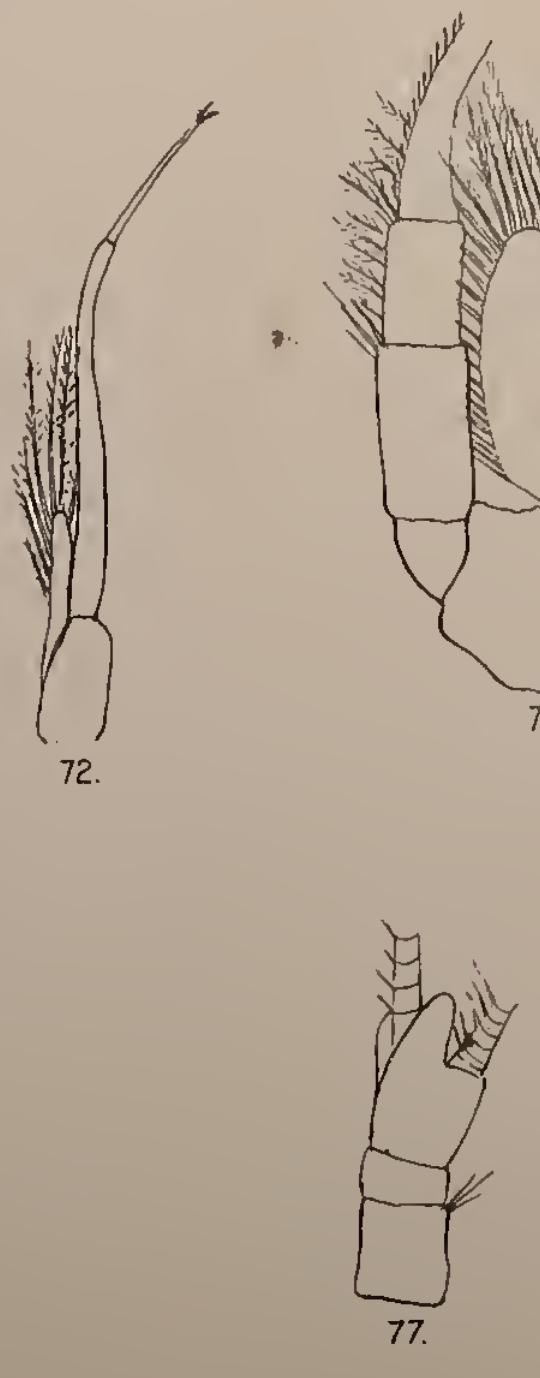

HOLMES, DEL.
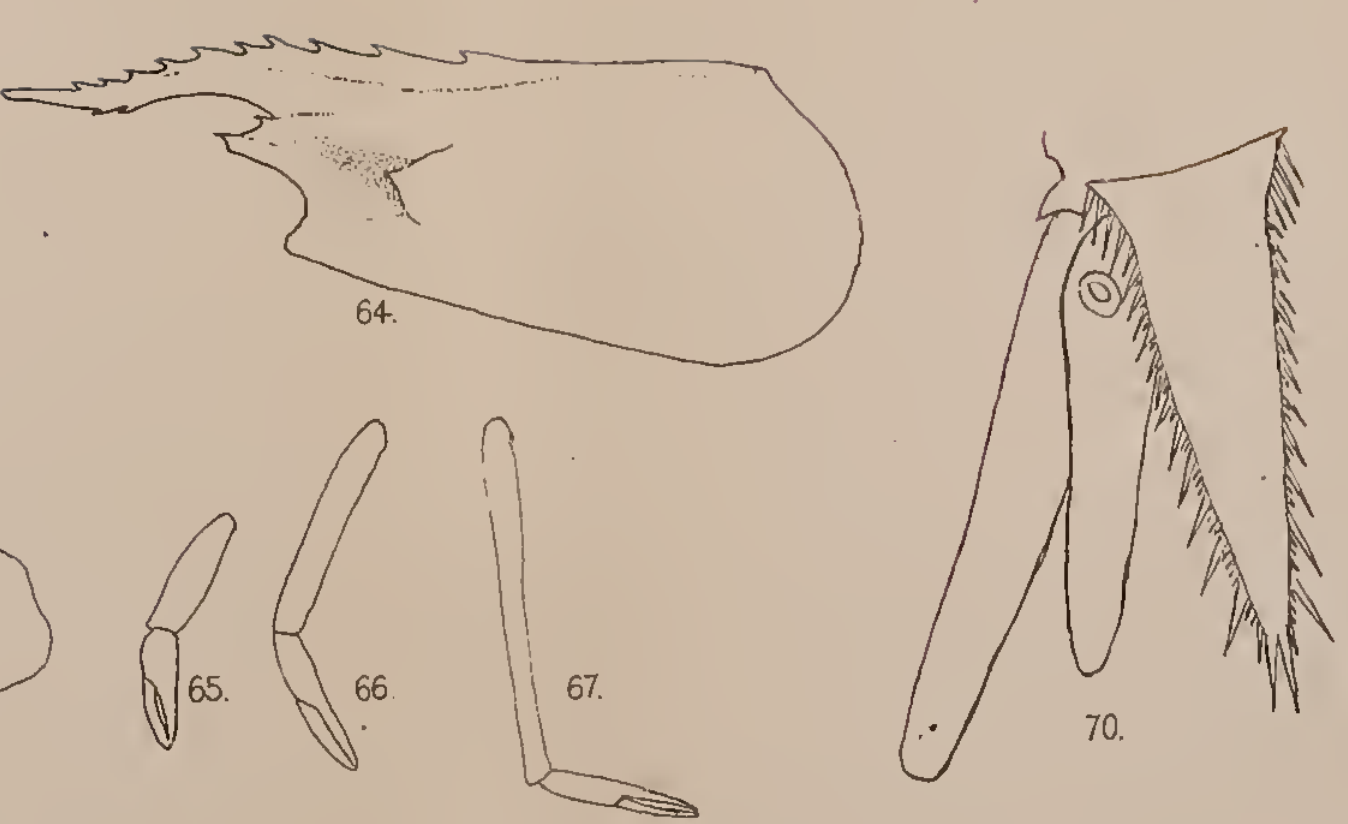

73.

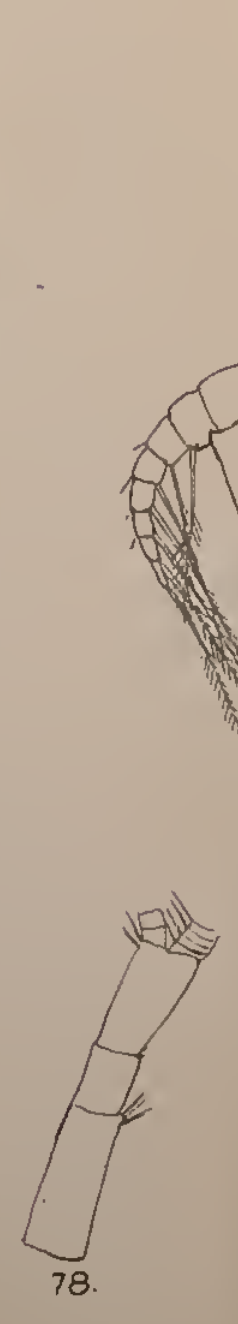

[Holmes] Plate IV.
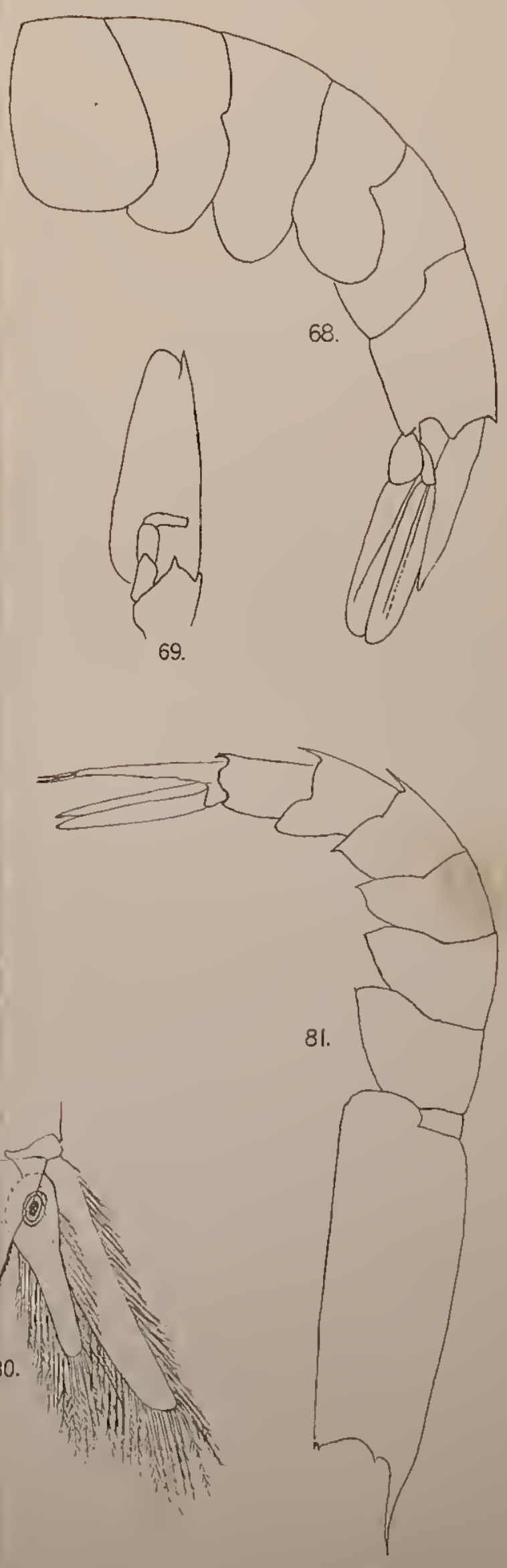

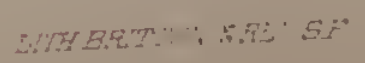







\section{•}

$-$ 

$5,5,3,5,5,5$

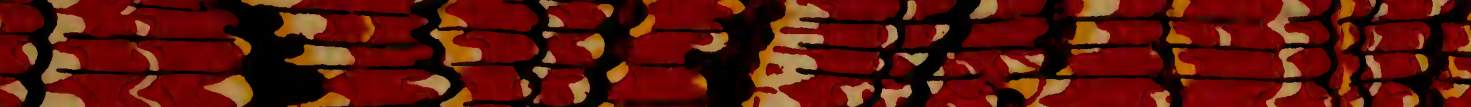
$3,2=3,3 x\}$ ; 3 ,

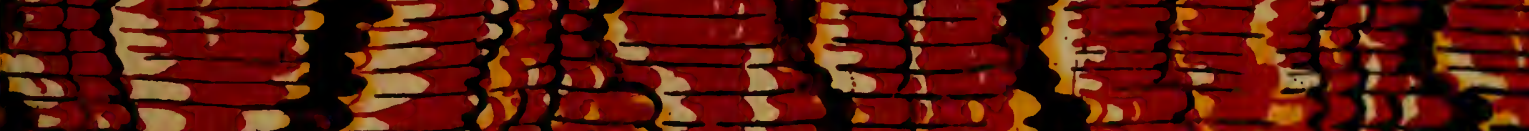

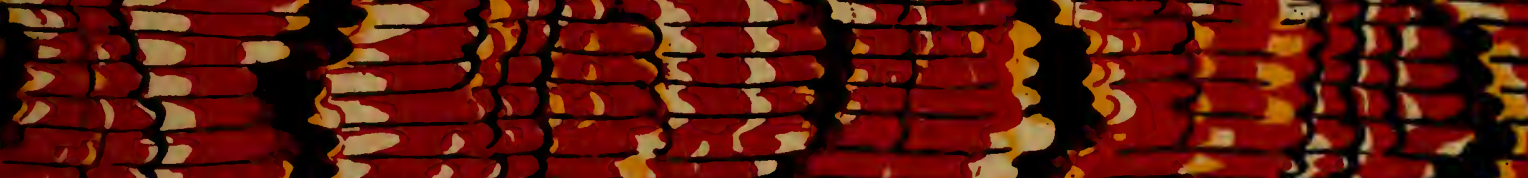
(3)

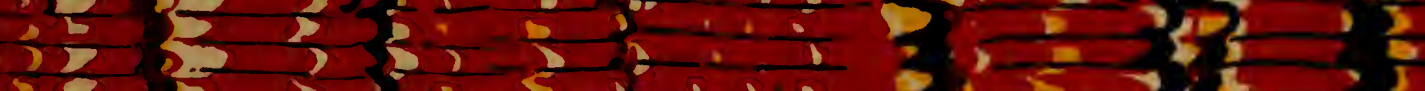

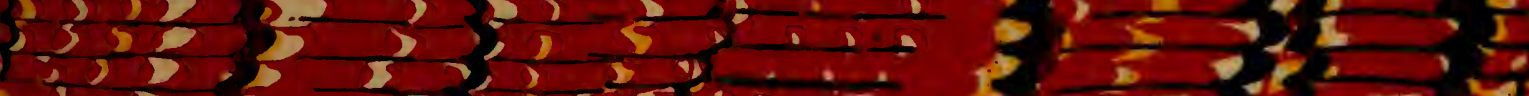
; \{ \{ \{3, \}, $\}$

1 313

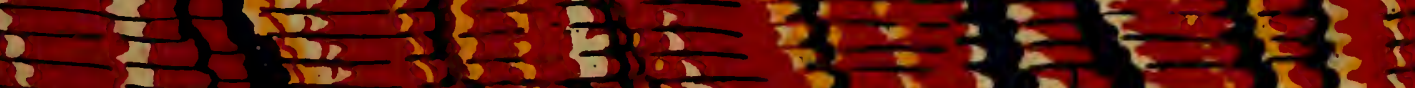

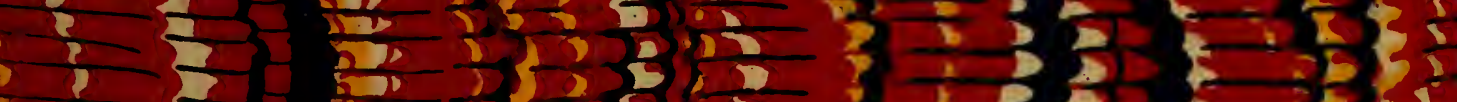
द 7 ?

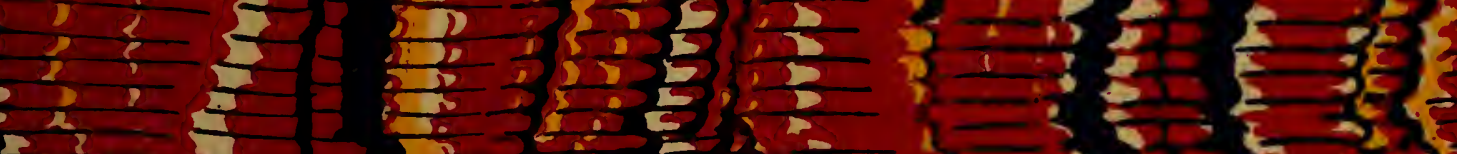
313,53 , 3

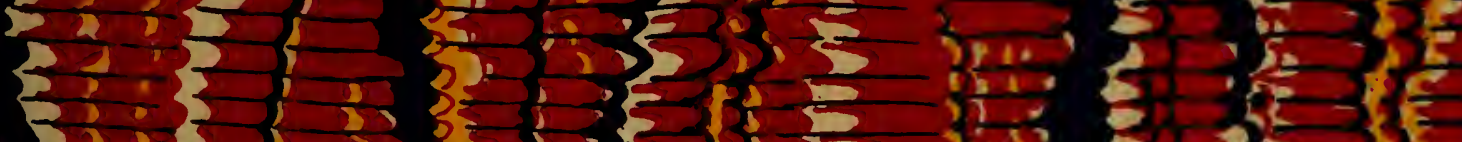
i.

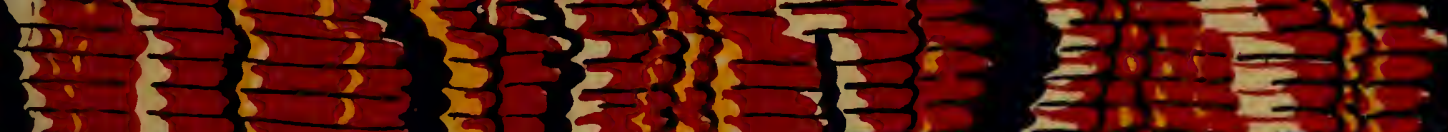

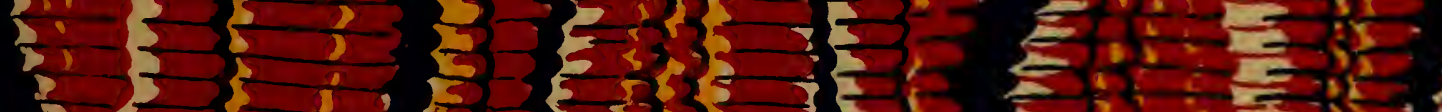

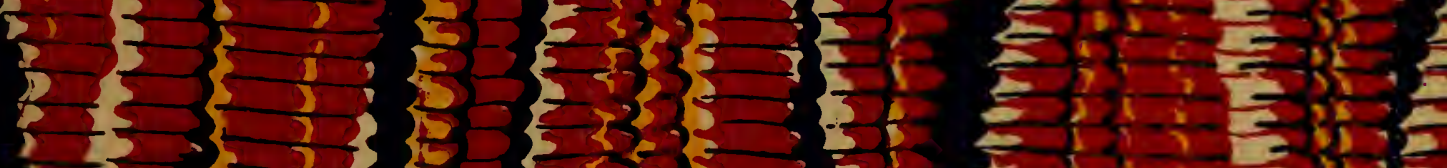

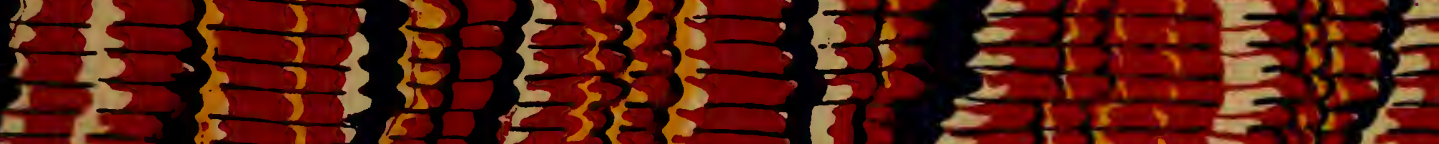

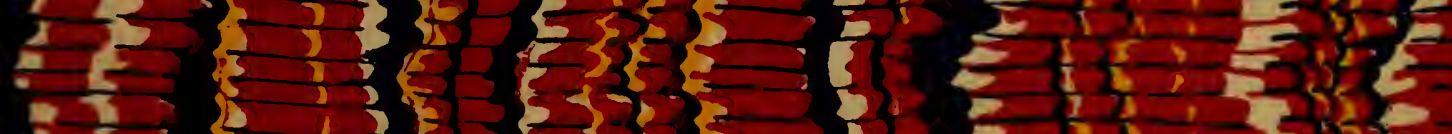
5 is 35

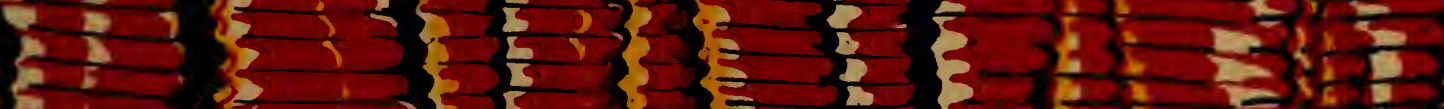
$\left\{\begin{array}{l}3 \\ 5\end{array}\right.$ $3235\}=35=1$, , 2 30 , 10

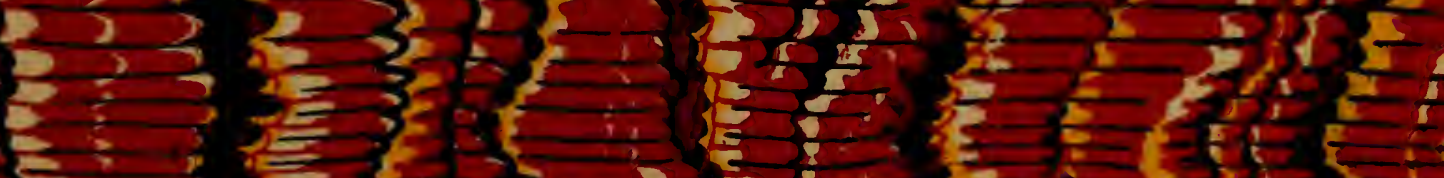
s.5

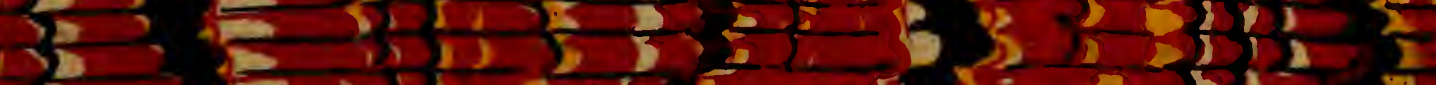


